PhD ÉRTEKEZÉS

Dúl János

\title{
A társasági jog és az öröklési jog kapcsolódási pontjai osztrák jogi fragmentumokkal
}

Témavezető: Prof. Dr. Papp Tekla egyetemi tanár

Szegedi Tudományegyetem

Állam- és Jogtudományi Kar

Doktori Iskola

Szeged

2018 


\section{Tartalomjegyzék}

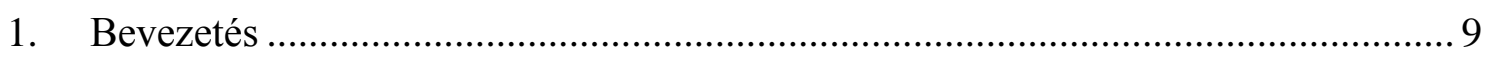

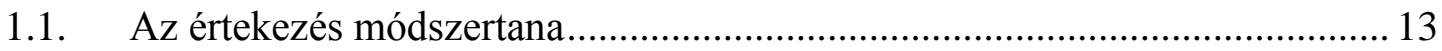

2. A társasági jog és az öröklési jog határán: jogtörténeti fejtegetés 1945-ig ............. 15

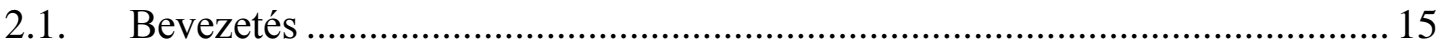

2.2. A társasági vagyon átszállásának első felbukkanásai Magyarországon ......... 17

2.3. Az 1839/1840. évi országgyülés kereskedelmi tárgyú törvényei ................... 19

2.4. A kereskedelmi jog öröklési vetületének megjelenése ................................. 20

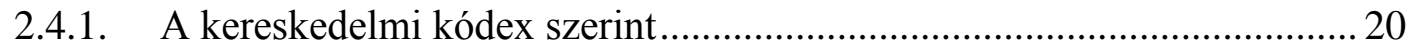

2.4.2. A kereskedő utáni öröklés; a kereskedelmi társaságokról általában......... 21

2.5. A kereskedelmi jog öröklési vetülete speciális jogszabályok szerint ............. 24

2.6. Az öröklési jog megjelenése az egyes kereskedelmi társaságoknál ............... 26

2.6.1. A közkereseti társaság .................................................................... 27

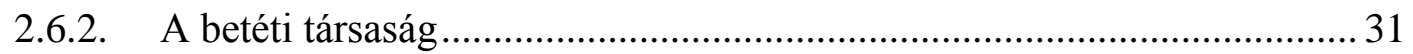

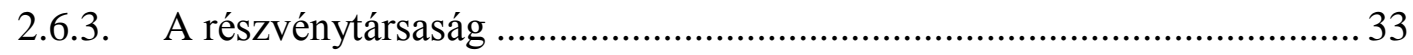

2.6.4. A korlátolt felelősségü társaság ........................................................... 34

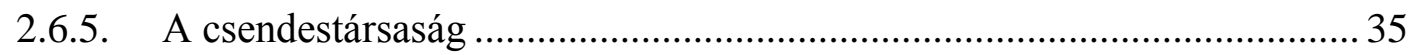

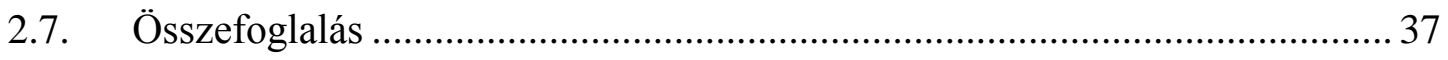

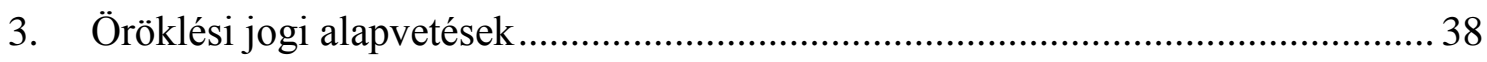

3.1. Az addicionális és az ipso iure öröklési rendszer ......................................... 38

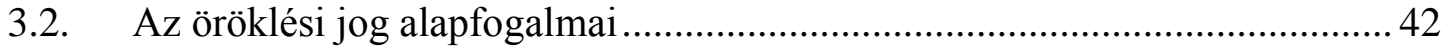

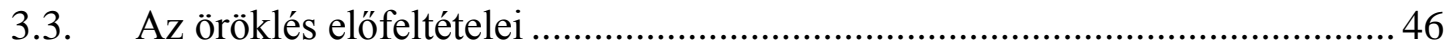

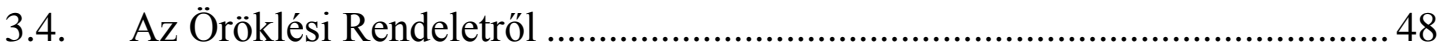

3.4.1. Az Öröklési Rendelet alapján megállapítható jog ................................. 50

3.4.2. Az öröklés fogalma az Öröklési Rendeletben........................................52

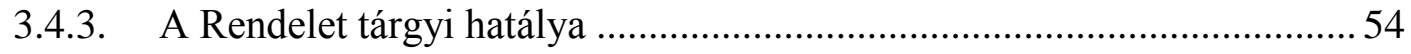

3.4.3.1. A rendelet tárgyi hatálya alól kizárt esetek ........................................55

3.5. A hagyatéki eljárás és a gazdasági társaságok ...............................................58

4. Az öröklési jog megjelenése az egyes gazdasági társaságoknál........................... 61

4.1. A tag halálának társaságra gyakorolt hatása ............................................. 61

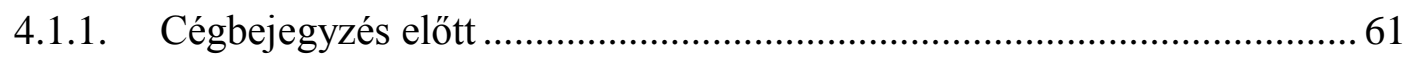

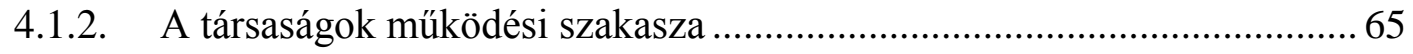




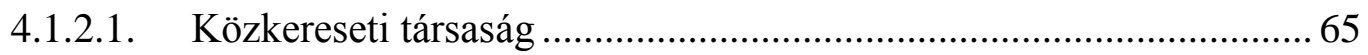

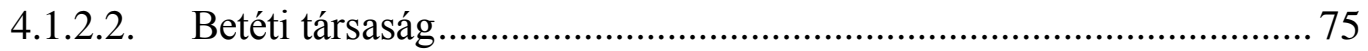

4.1.2.3. Korlátolt felelősségü társaságok és részvénytársaságok .................. 81

4.1.3. A gazdasági társaságok megszüntetése körében alkalmazott eljárások.... 83

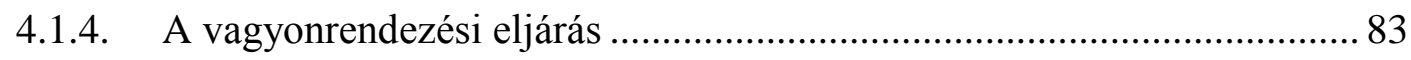

4.2. Az örökösök jogi helyzete az egyes társaságoknál ........................................ 84

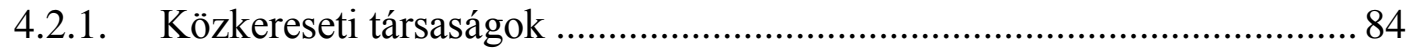

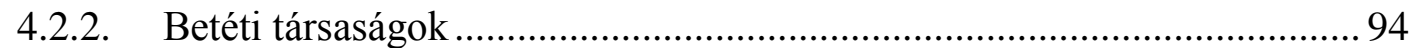

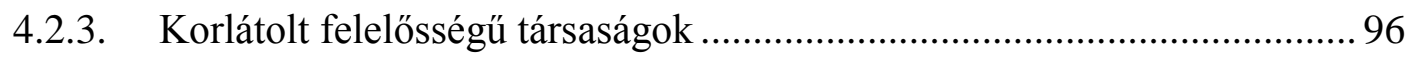

4.2.3.1. Az üzletrész átszállása ................................................................ 105

4.2.3.2. Közös tulajdonú üzletrész keletkezése ......................................... 111

4.2.3.3. Az üzletrész felosztása ............................................................. 115

4.2.3.4. Az üzletrészen fennálló özvegyi jog........................................... 120

4.2.3.5. Az üzletrész öröklése ági öröklés útján ......................................... 128

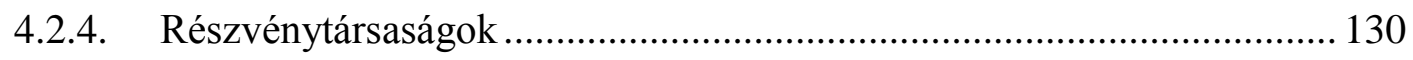

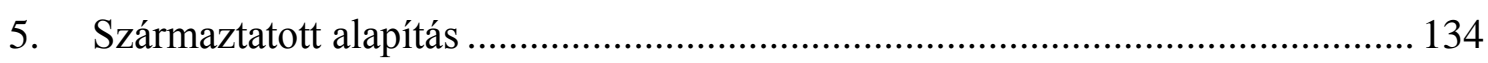

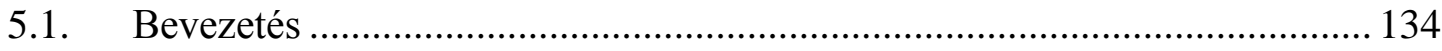

5.2. A szabályozástól való eltérés lehetősége ................................................... 135

5.3. A származtatott alapítás hatályos szabályozási struktúrája ......................... 136

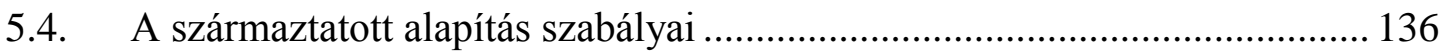

5.4.1. A gazdasági társaságok átalakulása ................................................ 137

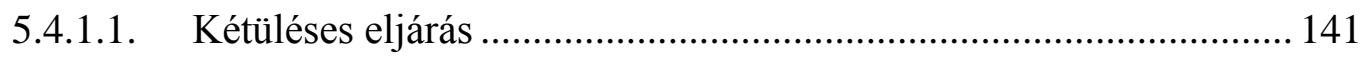

5.4.1.2. Együléses eljárás ....................................................................... 144

5.4.2. A gazdasági társaságok egyesülése...................................................... 146

5.4.3. A jogi személyek szétválása .............................................................. 147

5.5. Az osztrák szabályozás alapjai ................................................................ 148

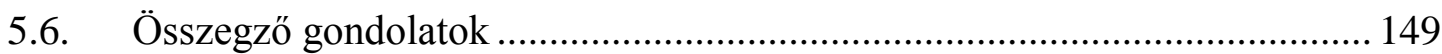

6. A közös veszélyben elhunyt társasági tagok utáni jogutódlás rendezése ............. 151

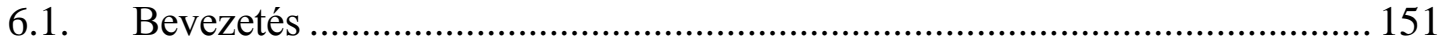

6.2. A közös veszélyben elhunytak utáni öröklés rendezésének lehetséges

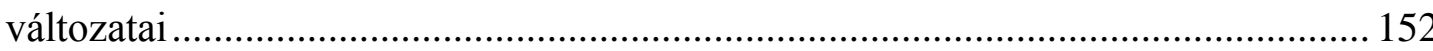

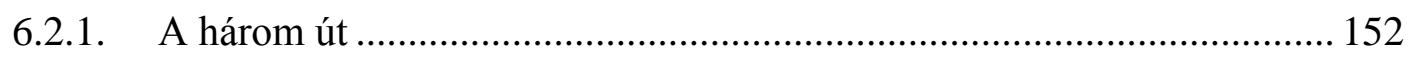

6.2.1.1. A fizikai ellenálló képességen alapuló vélelmek............................. 152

6.2.1.2. Az egyszerre elhalás vélelmezése ............................................... 153 
6.2.1.3. A kódex hallgatása

6.2.2. A közös veszély szabályozásának első megjelenése a magyar jogban... 156

6.2.3. A közös veszély a hatályos magyar szabályozás szerint ....................... 156

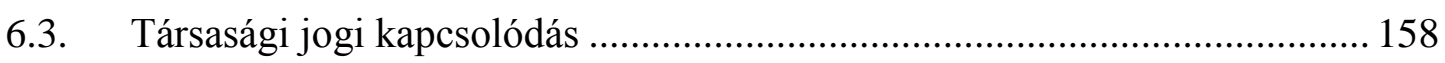

6.3.1. A vélelem alkalmazása házastársak halála esetén .............................. 159

6.3.2. A közös veszélyre vonatkozó vélelem alkalmazása házastársak és a közös veszélyben érintett közös gyermekük halála esetén .......................................... 164

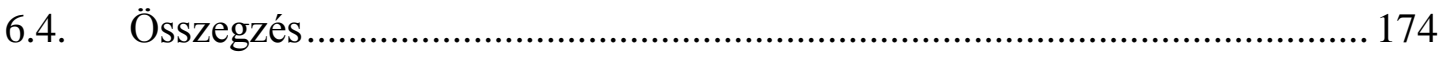

7. Speciális társulások öröklési jogi vonatkozásai .............................................. 176

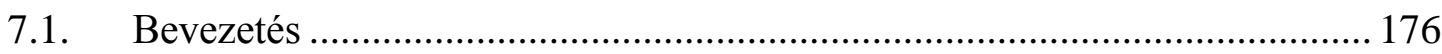

7.2. A speciális társulások osztályozása …......................................................... 176

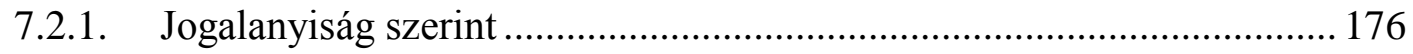

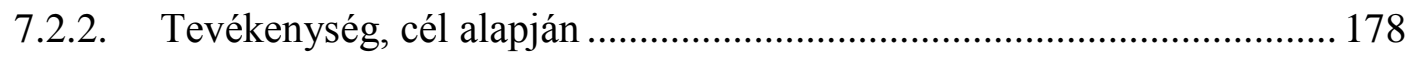

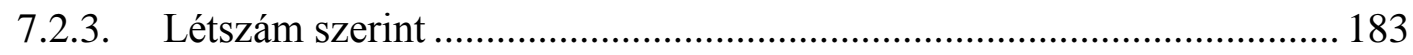

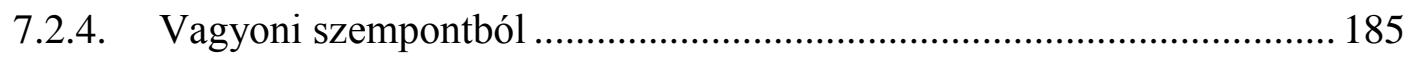

7.3. A családi vállalkozások ……………........................................................ 188

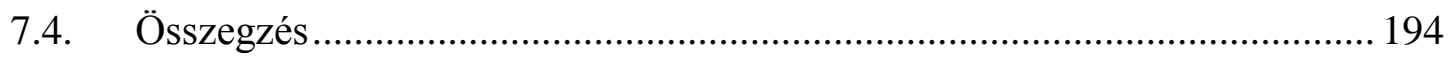

8. Az öröklési szerződés szerepéről a társasági jogban .......................................... 196

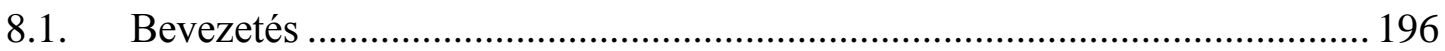

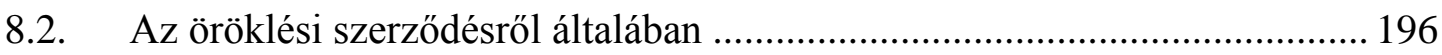

8.3. A társasági részesedések átruházása öröklési szerződéssel ......................... 198

8.3.1. Közkereseti és betéti társaságok esetén .............................................. 199

8.3.2. Korlátolt felelősségü társaságok ......................................................... 201

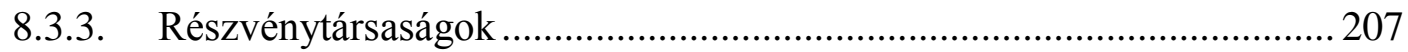

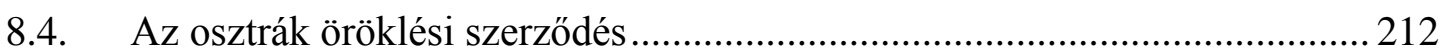

9. A hagyatéki tartozásokért való felelősség társasági jogi kitekintéssel ................. 214

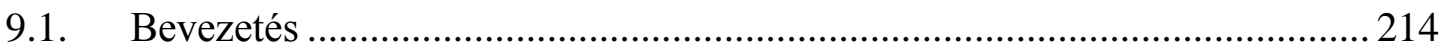

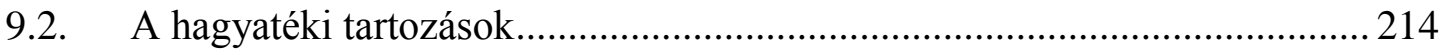

9.2.1. Az örökhagyó illő eltemetésének költségei ........................................ 217

9.2.2. A hagyatéki költségek és a hagyatéki eljárás költségei ......................... 218

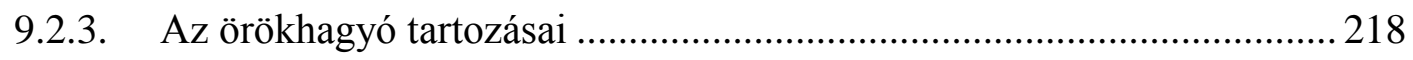

9.2.4. A kötelesrészen alapuló kötelezettségek............................................ 219

9.3. A hagyatéki tartozásokért való helytállás …................................................ 221

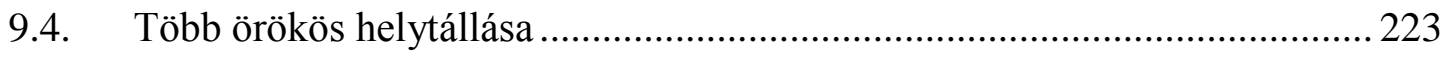




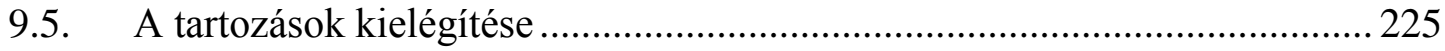

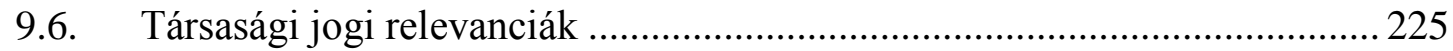

9.6.1. A hagyatéki tartozásokért való felelősség a közkereseti társaságban és a

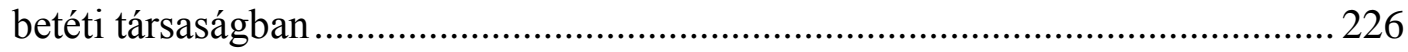

9.6.2. A korlátolt felelősségü társaságok és a részvénytársaságok ................... 228

9.7. A hagyatéki tartozások osztrák szabályozásáról............................................ 229

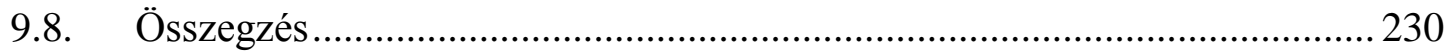

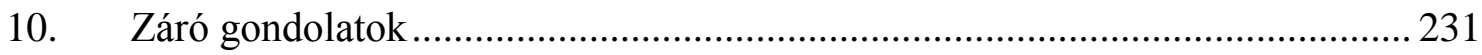

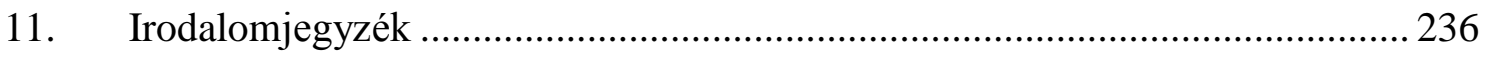

12. Felhasznált jogszabályok, eseti döntések....................................................... 254

A kézirat lezárásának dátuma: 2017. december 31. 


\section{Köszönetnyilvánítás}

Köszönetemet és hálámat szeretném kifejezni mesteremnek, Prof. Dr. Papp Tekla professzor asszonynak, akinek útmutatása, tanácsai, az értekezés összes fejezetének (a témavezetőktől általában elvárható magatartást messze túlszárnyalva) és a témában megírt tanulmányok kéziratainak gondos átnézése nélkül nem jöhetett volna létre ez a munka.

Szeretném megköszönni családomnak, akik végig támogatásukról és szeretetükről biztosítva stabil hátteret nyújtottak számomra.

Köszönet illeti meg a fokozatszerzési eljárásomban részt vevők, a munkahelyi vitára beérkezett vélemények szerzőit, különösen a két hivatalos bírálómat, Dr. Barta Judit docens asszonyt és Prof. Dr. Miskolczi Bodnár Péter professzor urat, akik véleményükkel hozzájárultak annak lehetőségéhez, hogy az értekezés még kiforrottabb munka lehessen.

Köszönöm Dr. Auer Ádám adjunktus, dr. Nagy Barna Krisztina tanársegéd és dr. Lehoczki Zóra Zsófia PhD-hallgató lelkiismeretes munkáját a kézirat munkahelyi vitára alkalmassá tételéért.

A jogtörténeti fejezet korábbi változatához füzött tanácsaiért köszönet illeti Prof. Dr. Fülöpné Prof. Dr. Homoki-Nagy Mária professzor asszonyt.

Az értekezés témájának nemzetközi vizsgálatához, az anyagok hozzáférhetőségéért és a konzultációkért köszönet illeti Prof. Dr. Martin Winner professzor urat, a Wirtschaftsuniversität Wien Forschungsinstitut für mittel- und osteuropäisches Wirtschaftsrecht vezetőjét és Dr. Vecsey Márkot, a kutatóintézet munkatársát.

A 2016 szeptemberében megvalósult bécsi kutatóúthoz a Tempus Közalapítvány Campus Mundi programja nyújtott pénzügyi támogatást. 


\section{Rövidítésjegyzék}

ABGB

ADHGB

AktG

Átv.

Ávtv.

Bányatv.

BDT

BGB

BH

Ctv.

EBH

Ebtv.

Eütv.

Evc. tv.

GmbHG

Gt.

Hetv.

ÍH

Kfttc.

Kt.

Nmjtvr.

Nvt.

Öröklési Rendelet/

ÖR
Allgemeines Bürgerliches Gesetzbuch

Allgemeines Deutsches Handelsgesetzbuch

Aktiengesetz

2013. évi CLXXVI. törvény az egyes jogi személyek átalakulásáról, egyesüléséről, szétválásáról

2007. évi CVI. törvény az állami vagyonról

1993. évi XLVIII. törvény a bányászatról

Bírósági Döntések Tára

Bürgerliches Gesetzbuch

Bírósági Határozatok

2006. évi V. törvény a cégnyilvánosságról, a bírósági cégeljárásról és a végelszámolásról

Elvi Bírósági Határozat

1994. évi XLIX. törvény az erdőbirtokossági társulatról

1997. évi CLIV. törvény az egészségügyről

2009. évi CXV. törvény az egyéni vállalkozóról és az egyéni cégről

GmbH-Gesetz

2006. év IV. törvény a gazdasági társaságokról

2010. évi XXXVIII. törvény a hagyatéki eljárásról

Ítélőtáblai Határozatok

1930. évi V. tc. A korlátolt felelősségü társaságról és a csendes társaságokról

1875. évi XXXVII. tc. Kereskedelmi törvény

1979. évi 13. törvényerejű rendelet a nemzetközi magánjogról

2011. évi CXCVI. törvény a nemzeti vagyonról

Az Európai Parlament és a Tanács 650/2012/EU rendelete (2012. július 4.) az öröklési ügyekre irányadó joghatóságról, az alkalmazandó jogról, az öröklési ügyekben hozott határozatok elismeréséről és végrehajtásáról, valamint az öröklési ügyekben 
kiállított közokiratok elfogadásáról és végrehajtásáról, valamint az európai öröklési bizonyítvány bevezetéséről

Ptk. 2013. évi V. törvény a Polgári Törvénykönyvről

Ptké. 2013. évi CLXXVII. törvény a Polgári Törvénykönyvről szóló 2013. évi V. törvény hatálybalépésével összefüggö átmeneti és felhatalmazó rendelkezésekről

régi Ptk. 1959. évi IV. törvény a Polgári Törvénykönyvröl

SpaltG Spaltungsgesetz

Sztv. 1991. évi XXXIV. törvény a szerencsejáték szervezéséről

UGB Unternehmensgesetzbuch

UmwG

Umwandlungsgesetz

Vgt.

1995. évi LVII. törvény a vízgazdálkodásról

ZGB

Zivilgesetzbuch 


\section{Bevezetés}

A társasági jog olyan átfogó, tág kategória, amely több jogág részének tekinthető joganyagot ölel fel. ${ }^{1}$ Alapvető polgári jogi meghatározottsága - tekintettel arra, hogy nem minősül önálló jogágnak, hanem a polgári jogon belüli önálló jogterületnek ${ }^{2}$ ellenére sem feleltethető meg teljes mértékben ezzel a jogággal. Nagymértékben meghatározzák a közjogi elemek, különösen a cégeljárás, ${ }^{3}$ valamint a pénzügyi jog ${ }^{4}$ vonatkozásában.

A polgári jog másik jogterületét képező öröklési jogra is jelentős közjogi behatás irányul, például a pénzügyi jog területére tartozó öröklési illeték, de még inkább a hagyatéki eljárás formájában azzal, hogy a magánjog öröklési anyagi jogi szabályokra gyakorolt dominanciája kétségbevonhatatlan.

Az öröklési jog a magyar polgári jogi kodifikációs tervezetek és a régi Ptk. integráns részét képezte, nincs ez másképp a 2014. március 15-től hatályos Polgári Törvénykönyvben sem. A jogterület legfontosabb kérdéskörei közé tartozik, hogy mely személyek, milyen arányban lesznek az örökhagyó egyetemes jogutódjai, ${ }^{5}$ milyen sorrendben (törvényes öröklés); ${ }^{6}$ el lehet-e térni a törvény által meghatározott szigorú sorrendtöl, ha igen, ezt milyen módon és tartalommal teheti meg az örökhagyó. ${ }^{7}$ Végintézkedés esetében vannak-e olyan személyek, akik ennek ellenére a vagyon egy részére igényt tarthatnak; ${ }^{8}$ végül az örökösök, miután rájuk az örökhagyó vagyoni jellegü jogai és kötelezettségei egyaránt átszállnak, ${ }^{9}$ a kötelezettségekért milyen módon és mértékben állnak helyt. ${ }^{10}$ Meglátásom szerint azért fontos az öröklési jog részletes szabályozottsága, hogy a tulajdoni viszonyok a lehető legáttekinthetőbbek lehessenek, továbbá annak érdekében, hogy ezáltal elkerülhetővé váljon az egyes hagyatéki vagyonelemek uratlanná válása.

\footnotetext{
${ }^{1}$ Papp 2011b. 13. Az értekezésben a társasági jogi dogmatikai kérdések kidolgozásánál Papp Tekla által szerkesztett Társasági jog (Papp 2011b.) címủ munkát vettem alapul.

${ }^{2}$ Papp 2011b. 15.

${ }^{3}$ Ctv.; 21/2006. (V. 18.) IM rendelet a cégbejegyzési eljárás és a cégnyilvántartás egyes kérdéseiről; 24/2006. (V. 18.) IM rendelet az elektronikus cégbejegyzési eljárás és cégnyilvántartás egyes kérdéseiröl

${ }^{4}$ 2000. évi C. törvény a számvitelről; 2007. évi LXXV. törvény a Magyar Könyvvizsgálói Kamaráról, a könyvvizsgálói tevékenységröl, valamint a könyvvizsgálói közfelügyeletről; 1996. évi LXXXI. törvény a társasági adóról és az osztalékadóról

${ }^{5}$ Ptk. 7:1-7:9. §, 7:87-7:93. §

${ }^{6}$ Ptk. 7:55-7:74. §

${ }^{7}$ Ptk. 7:10-7:54. §

${ }^{8}$ Ptk. 7:75-7:86. §

${ }^{9}$ Ptk. $7: 1 . \S$

${ }^{10}$ Ptk. 7:94-7:100. §
} 
A társasági jog számos ponton kapcsolódik az öröklési joghoz, amelynek szabályait egy az egyben nem tudjuk alkalmazni a társasági jog sajátos jogági jellege folytán, ugyanis ,a társaságok természete nem viseli el, hogy öröklés útján, a felek akaratától függetlenül kényszerüljenek a társaság megmaradó tagjai olyan személlyel (az elhunyt tag jogutódjával) együttmüködni, akivel az együttmüködést nem kívánják." részvény átszállhat a jogutódra, ugyanakkor további kérdések relevánsak e társaság vonatkozásában is, míg a többi társasági formánál már nem ennyire egyszerü a megoldás.

$\mathrm{Az}$ értekezés kiindulópontjaként annak a kutatási kérdésnek, feltevésnek a megválaszolása szolgált, miszerint a társasági jog a pontosan körülírt, olykor a bírói gyakorlat által korrigált öröklési jogi szabályokat eltéríti, az ipso iure elven felépített magyar öröklési jogi szabályok teljes mértékben nem érvényesülhetnek abban az esetben, ha a hagyatékban társasági részesedés (közkereseti és betéti társaságoknál társasági részesedés, korlátolt felelősségü társaságok esetén üzletrész, míg részvénytársaságoknál részvény) lelhető fel. Az alapvetően személyegyesítő társaságokként besorolt közkereseti és betéti társaság esetében hasonló szabályok érvényesülnek, az eltérések a betéti társaságnál, a jellegadó ismérvként meghatározott két eltérő állású tag miatt jelentkeznek. Az öröklés ipso iure jellegét erősítve fogalmazták meg a Ptk.-ban a korlátolt felelösségü társaságokra, valamint a cégbejegyzés után létrejövő üzletrész öröklésére vonatkozó szabályokat, azonban teljes automatizmusról nem beszélhetünk itt sem, az alapvetö öröklési jogi kérdések mellett további releváns problémák is kifejtésre kerülnek. A részvények, mint forgalomképes értékpapírok vonatkozásában a többi társasági típushoz hasonló kérdések nem vetődnek fel, az öröklési jog ipso iure jellege erősebben tud érvényesülni, bizonyos részvényfajták esetében azonban kérdések merülnek fel.

A téma aktualitását adja az, hogy a bírói gyakorlatban több alkalommal felmerült valamely résztémával kapcsolatos tényállás, amelyek megoldására elsősorban ugyan elegendő a törvényi szabályozás megfelelő értelmezése, de az ilyen esetek felsőbb szintű bíróságokra (ítélőtáblák, Kúria) jutása azt jelentheti, hogy a társasági részesedések örökölhetőségére irányuló alapvető szabályok még nem gyökereztek meg eléggé a jogi köztudatban.

\footnotetext{
${ }^{11}$ Kisfaludi 1991. 149.
} 
Az értekezés célja a társasági jog és az öröklési jog kapcsolódási pontjainak feltárása, jogtörténeti aspektusának bemutatása és osztrák jogi szempontú jogösszehasonlító elemzése. Ennek érdekében a dolgozat a jogtörténeti résszel kezdődik (2. rész), megfelelő alapozást nyújtva a téma szempontjából releváns, és a dolgozat későbbi részeiben is használt öröklési jogi alapfogalmak tisztázása után (3. rész) a munka gerincét adó 4. résznek. A fejezet a téma dinamikus és statikus vizsgálatát tartalmazza, amikben egyrészt kifejtésre kerül az, hogy a társaságok egyes létszakaszaiban a társaságra nézve milyen hatást gyakorol valamely tagjának halála, illetve hogyan jelenik meg az elhunyt tag hagyatékában az (összefoglalóan) társasági részesedésnek nevezett vagyonelem. A társaságok létszakaszának speciális eleme a származtatott alapítás elnevezéssel összefoglalható létszakasz, ami magában foglalja a társasági formaváltást (átalakulást), a társaságok egyesülését, valamint szétválását. Az egyes eljárási momentumok alatt meghalhat valamely tag, ennek az átalakulási (egyesülési, szétválási) eljárásra gyakorolt hatásait veszi górcső alá az 5. fejezet. A közös veszélyben elhunytak jogi szabályozásának alapvető koncepcióváltása került kodifikálásra a Ptk.-ban, az ilyen eseményben érintett volt társasági tag utáni jogutódlás rendezésére kíván megoldást nyújtani a 6. rész különféle - egyelöre hipotetikus - esetekre. A társasági jogon túlmutató személy- és vagyonegyesülések tagjainak halála esetére irányadó szabályokat, mintegy exkurzusként, de a teljes összkép kívánalmával foglalja magába a 7 . fejezet. Öröklés révén, azaz az örökhagyó halálával száll át a társasági részesedés akkor is, ha az egy öröklési szerződés tárgya, eltérő azonban abban, hogy egyúttal átruházási jogcímnek is minősül az öröklési szerződés, az értekezés 8. része ezt a sajátosságot tárgyalja. A 9. rész a hagyatéki tartozások kielégítését elemzi a társasági jog tükrében, megvizsgálva azt, milyen módon kell helytállnia a tag örökösének jogelődje tartozásaiért, amit a 10. fejezetben az értekezés összefoglalása követ. A fejezetek tagolásából látszódik, hogy bizonyos részek egymással szorosabb, mások lazább kapcsolatban állnak, azonban nem szabad figyelmen kívül hagyni azt, hogy a kutatási célként kitüzött kapcsolódási pontok is mozaikszerüen, sporadikusan helyezkednek el jogunkban, erre figyelemmel nehéz a teljes koherencia megalkotása.

Az értekezés tárgyához szorosan kapcsolódó társasági jogi szabályok elemzésére akképp került sor, hogy összehasonlítottam a 2006. évi Gt., valamint a Ptk. vonatkozó rendelkezéseit. Habár ezek több ponton hasonlítanak egymásra, ugyanakkor több esetben alapvető eltérések fedezhetőek fel, ezek vizsgálatához pedig elengedhetetlen a korábbi szabályok ismerete. Tettem ezt azért is, mert a Ptké. értelmében a 2014. március 
15-e előtt megnyílt hagyatékokra még a régi Ptk. szabályait kell figyelembe venni, ${ }^{12}$ a társasági jogi részesedésekre pedig a Gt. rendelkezéseit. A bírósági gyakorlatban, figyelembe véve a hagyatéki eljárásokra és a peres eljárásokra vonatkozó szabályokat, még előfordulhatnak olyan esetek, amikor még a régi Ptk. és a Gt. alkalmazására kell sort keríteni.

Az értekezésbe beépítésre került a vonatkozó részeknél jogösszehasonlító céllal az osztrák jogi szabályozás töredékes, mintegy fragmentált formában. Az osztrák jog több ponton érintkezik a magyar joggal, sok hasonlóságot mutatnak egymással, ez a történelem folyamán létrejött kapcsolat révén alakult ki, később pedig a közös európai uniós tagság hatása. A jogrendszer választását indokolja még az, hogy az osztrák társasági jog is figyelemmel kísérte a német kereskedelmi jogi fejlődést, annak eredményeire is támaszkodott, továbbá a szintén közös kontinentális jogcsaládhoz való tartozás, a hasonló társadalmi igények, az, hogy az osztrák öröklési jogot is módosították több helyen a 2017 januárjától hatályos szabályozással. Mindezekre figyelemmel az osztrák jogi megoldások megfelelő mintaként szolgálhatnak a magyar jog számára. Az alapvető egyezések - mint például a mindkét jogrendszerben fellelhető gazdasági társasági formák - mellett, azzal, hogy az osztrák társasági jog a hatályos magyar jogban ismeretlen - és létre sem hozható ${ }^{13}$ - típusokat is ismer, pl. a magyar társasági jogban nem került nevesítésre a $\mathrm{GmbH} \&$ Co. KG-nak megfelelő formáció, a vonatkozó elöírásokban fundamentális eltérések fedezhetők fel, ami különösen a személyegyesítő társaságoknál szembeötlő. Ezeknek elemzése osztrák jogirodalmi és joggyakorlati vizsgálatot vont maga után, amelyeknek magyar joggal való összehasonlítása hasznos eredményekkel szolgált. Az egyes osztrák társaságokra vonatkozó szabályozást - az 1988-tól kezdődő magyar jogi hagyományoktól eltérően nem egy kódex tartalmazza, hanem több különálló törvény. Az osztrák közkereseti és betéti társaság az UGB-ben, ${ }^{14}$ a korlátolt felelősségü társaság a GmbHG-ben (Gesetz vom 6. März 1906, über Gesellschaften mit beschränkter Haftung), a részvénytársaság pedig az AG-ben (Aktiengesetz) került szabályozásra. A szabályok töredékes beépítését azok témához mért relevanciája indokolta. A dolgozatban a releváns pontoknál az Európai Unió öröklési jogi tárgyban megalkotott rendeletének szabályai is feldolgozásra kerülnek. E szabályok önálló fejezetben való szerepeltetése nem indokolt, tekintettel a

\footnotetext{
12 Ptké. 57. $\S(1)$ bek.

${ }^{13}$ Ptk. 3:1. § (4) bek., Ptk. 3:89. § (1) bek.

${ }^{14}$ Az Unternehmensgesetzbuch 2007. január 1-jén lépett hatályba, az általa bevezetett újításokat kiválóan összefoglalja Szikora Veronika, lásd Szikora 2008. 3-7.
} 
munka egészéhez mért kisebb terjedelmére, valamint az absztraháció magasabb fokára való törekvésre.

\subsection{Az értekezés módszertana}

A dolgozat megírása során a hagyományos jogelméleti módszerek kerültek alkalmazásra, az első részekben a leíró jelleg dominál, az öröklési jogi alapfogalmaknál a fellelhető kommentárok, szakcikkek, illetve tankönyvek által használt kifejezések, definíciók lelhetőek fel, ugyanígy a jogtörténeti fejezetben a mai, illetve a korabeli irodalmi álláspontok, valamint a bírói gyakorlatot elemeztem, összevetettem azokat a releváns törvényekkel. Bár nem jogtörténeti, hanem hatályos joggal összefüggő témája van a dolgozatnak, azonban elengedhetetlennek tartottam a fejezetben leírtakat felvázolni a teljesebb kép érdekében, már csak azért is, mert a korábban hatályos jogszabályok, illetve az arra épülő joggyakorlat szervesen meghatározza a mai szemléletmódot is, gondolhatunk itt csupán az alapvető társasági típusokra. Az ezekben az években a joggyakorlatban felmerült esetek megfelelően alátámasztják, hogy a vizsgált kérdések akkor is aktuálisak voltak, sok döntés közzétételére sor is került, valamint mindezeket a döntéseket és a bennük felmerült kérdéseket neves jogtudósaink is vizsgálták hol kisebb, hol nagyobb terjedelemben. Az értekezés további részeiben ugyancsak beépítettem az odailleszkedő szakirodalmat amellett, hogy ezekben a fejezetekben markánsabban előtérbe lehetett helyezni a saját véleményt, a jogszabályok, de még inkább a joggyakorlat értelmezése által diktált problémák megoldási javaslatait. Így e részekben a nyelvtani, valamint a logikai jogszabály-értelmezés dominál. A közzétett bírói döntések jelzik a gyakorlat bizonytalanságait, illetve a bíróságok jogegységesítő törekvéseit, az azokban foglalt tényállások az egyes kérdések vizsgálatához megfelelő kiindulópontként, a bíróságok által tett megállapítások pedig hasznos adalékul szolgáltak az értekezés megírása folyamán, jelezve egyúttal azt, hogy habár elsősorban elméleti fejtegetéseket tartalmaz a dolgozat, de célként került kitüzésre a jogélet által felvetett kérdések tekintetében de lege ferenda javaslatként megoldási alternatíva nyújtása is.

A vázoltaknak megfelelően a rendszerváltás utáni társasági jogi szabályozásból elsősorban a 2006. évi Gt., valamint a Ptk. rendelkezéseit vizsgáltam meg, a korábban hatályos gazdasági társaságokról szóló törvényeket (1988. évi VI. törvény és 1997. évi CXLIV. törvény) csak annyiban, amennyiben valamilyen jelentősebb változás 
következett be a rendelkezésekben, illetve ha az eltérő szabályozás valamely elemzett jogesetből kiderül, esetleg annak lényegére ki is hatott.

Mindezekre tekintettel az értekezés forrásaiként a hatályos, valamint a jogtörténeti fejezetbe illeszkedő, továbbá a modern kori, de már nem hatályos jogszabályok elemzését, a bírói gyakorlatot, illetve a szakirodalmi álláspontokat tartom számon. Idesorolandó még az általam meghatározónak tartott osztrák jogi töredékek kapcsán a releváns osztrák jogszabályok áttekintése, a közzétett bírói gyakorlat, valamint a jogirodalmi álláspontok ismertetése. Mindezek mellett az európai öröklési rendelet egyes résztémákhoz illesztett rendelkezéseinek ismertetése a fellelhető szakirodalmi elemzésekkel is a dolgozat integráns részeit képezik. 


\section{A társasági jog és az öröklési jog határán: jogtörténeti fejtegetés 1945-ig}

Jelen részben a társasági jog és az öröklési jog kapcsolatának jogtörténeti elemzésére vállalkozom a nemzetközi fejlődésre kitekintéssel. A vizsgálat 1945-ig, a II. világháború végéig terjed, az ezt követő politikai változások hatására ezen a területen is jelentős módosítás történt, amelyre az értekezésben nem térek ki. A fejezetben a mai értelemben vett gazdasági társaságok vonatkozásában az akkori szóhasználatnak megfelelő kereskedelmi társaságok kifejezést fogom használni azzal a kitétellel, hogy az egyébként a Kt. alapján kereskedelmi társaságnak minősülő szövetkezet nem lesz kifejtve figyelemmel arra, hogy az a hatályos jogban nem gazdasági társaság, így annak jogtörténeti gyökereinek elemzése (hatályos szabályozás nélkül) nem érdemes.

\subsection{Bevezetés}

A kereskedelmi társaságokat az a felismerés hozta létre, hogy a gazdasági és szellemi erők egyesítése a teljesítményt meghatványozza, valamint a kockázatot megosztja. Végső soron nem a római jogi magánjogi társaságokból (societas), hanem a személyegyesítő jellegü compagniákból és a commendákból alakultak ki, ${ }^{15}$ a jogi személyiséggel bíró társaságok létrejöttét egyedi engedélyhez kötötték. ${ }^{16}$

A középkori Itáliában, a XII-XIII. században fejlődött ki a legalább az egyik tag korlátolt felelőssége mellett müködő commenda, valamint a tagok egyenlő és korlátlan felelősségén alapuló compagnia. A commenda intézménye keretében az egyik fél (tőkéstárs) pénzt vagy árut adott át a másiknak, aki azzal szabadon kereskedhetett, és meghatározott időn belül köteles volt azzal elszámolni, ez a forma fokozatosan vált pénzkölcsönből csendestársasággá és a mai betéti társasággá. ${ }^{17}$ A compagnia keretében a tagok közös jövedelemszerző tevékenységet folytattak, a társaság kötelezettségeiért pedig közvetlen és egyetemleges felelősséggel tartoztak. A társaság maga ugyan nem rendelkezett a tagoktól elkülönült személyiséggel, vagyona azonban bírt azzal. ${ }^{18} \mathrm{E}$ formából keletkeztek úgy a közkereseti társaságok, hogy az elhunyt üzlettulajdonosok

\footnotetext{
${ }^{15}$ Horváth 2006. 393., Mezey (szerk.) 199.

${ }^{16}$ Papp 2011b. 586.

${ }_{17}^{17}$ Papp 2011b. 586., Török T. 2015. 113., Gummert 1-2.

${ }^{18}$ Papp 2011b. 587.
} 
örökösei az üzletet közösen folytatták tovább. A társak egyetemleges kötelezettsége kezdetben a családi viszonyon, a XIII. századtól a társak kölcsönös megállapodásán nyugodott. $^{19}$

A XVI-XVII. századi kodifikációs kísérletek hatására a XIX. században általános európai tendenciaként jelentkezett a kereskedelmi jog egységesítésére való törekvés (Franciaország, Spanyolország, Portugália, Olaszország, a német államok), azaz a modern társasági jog kialakulása a XVII-XVIII. századra tehető. ${ }^{20}$ Ebbe a vonulatba illeszkedik szervesen a magyar kereskedelmi törvény, az 1875. évi XXXVII. törvénycikk is.

A mai Németország területén sokáig nem született olyan jogszabály, amely érintené a vizsgált témakört. Az 1861-es Allgemeines Deutsches Handelsgesetzbuch (a továbbiakban: ADHGB) szabályozta az ún. offene Handelsgesellschaftot, amely a közkereseti társaságnak feleltethető meg, e társaságnál bármely tag halála megszüntette magát a társaságot. A törvény továbbá rendelkezett a Kommanditgesellschaftokról ezek a mai betéti társaságok -, amelyek szintén megszünnek a tag halála esetén, mert az offene Handelsgesellschaft szabályai irányadóak voltak ezekre a társaságokra is. ${ }^{21} \mathrm{~A}$ csendestársaság (stille Gesellschaft) gyökerei szintén a commendában keresendők, e formánál a csendestárs halála, ellentétben a beltag halálával vagy csődjével, nem szüntette meg a társaságot. ${ }^{22}$ 1896-ban váltotta fel az ADHGB-t a ma is hatályos Handelsgesetzbuch, e kódex tartalmazta a Partenreederei intézményét (hajózási társulást), amely nem volt se kereskedelmi társaság, se jogi személy. A formáció lényege az, hogy egy hajón hányadokra felosztott közös tulajdon állt fenn annak érdekében, hogy a felek tengeri utak alkalmával közös számlán vállalkozzanak. Ennél a formánál sem szüntette meg a tag halála vagy csődje a társaságot. ${ }^{23}$

Nagy-Britanniában nem számítottak bejegyzett társulási formának az angol vállalkozási formák legrégebbi típusai, az egyéni vállalkozás és a partnership, utóbbi müködéséhez az 1890-es Partnership Act teremtette meg a jogi keretet. A partnership esetén a tagok változása kihat a társulásra is: öröklés, kiválás vagy belépés esetén a társak egyhangú határozatával formailag újjáalakítják azt. ${ }^{24}$

\footnotetext{
${ }^{19}$ Horváth 2006. 401.

${ }^{20}$ Sándor I. 2000. 335.

${ }^{21}$ Papp 2011b. 592.

${ }^{22}$ Sándor I. 2005. 161., ADHGB 261. cikkely 1) bek.

${ }^{23}$ Sándor I. 2005. 162., ADHGB 472. cikkely, Papp 2011b. 593.

24 33. cikk (1) bek., Papp 2011b. 605.
} 
Svédországban a XVIII. században megalkotott Sveriges Rikes Lag nevü birodalmi törvénykönyvben is találunk utalást a társasági jog és az öröklési jog kapcsolatát illetően. A kereskedelmi jogi könyv (Handelsbalken) tartalmazza a társaságokat, amely sok tekintetben a római jogi szabályozáshoz hasonlít. A törvénykönyv szerint egy tag halála nem szünteti meg a társaságot, hanem azt az örököse tovább folytathatja. Abban az esetben azonban, ha az elhunyt a személyes képességei miatt volt a társaság tagja, az örököse akkor léphetett be a társaságba, ha ehhez valamennyi társasági tag hozzájárult. ${ }^{25}$

\subsection{A társasági vagyon átszállásának első felbukkanásai Magyarországon}

A szokásjog által meghatározott magyar magánjogban a kereskedelmi társaságok vonatkozásában nem találunk nyomokat. ${ }^{26}$

A személy- és vagyonegyesítő jelleget egyaránt felmutató polgári jogi formációk - több európai államhoz hasonlóan - a céhek voltak. „Minthogy az ipar és kereskedelem érdekeivel a jobbára nemesi törvényhozás nem sokat törődött: a városok polgárai maguk gondoskodtak boldogulásuk megvédéséről. Erre szolgáltak a céhek is." ${ }^{27} \mathrm{Az}$ ugyanazt az ipari tevékenységet folytatók körében hamar kialakult a közösséggé tartozás tudata, a XIII. századtól próbáltak testületté alakulni, hogy érvényesíteni tudják érdekeiket, majd a XIV. századtól beszélhetünk ténylegesen céhekröl, fokozatosan alakult ki az, miszerint adott tevékenységet csak céhtagság esetén lehet végezni. ${ }^{28}$

Az értekezés témájához illeszkedő törvényi szintű szabályozást nem találhatunk, hanem az ún. céhszabályok tartalmazták a rájuk irányadó rendelkezéseket. „A városi statútumok és a céhbíróságok megteremtették a jogrendszernek azon szellemét és azokat a jogintézményeket (amik közé sorolhatók a kereskedelmi társaságok is), amelyek segítségével a gazdasági élet Magyarországon is kibontakozhatott." ${ }^{29}$ A

\footnotetext{
${ }^{25}$ Sándor I. 2005. 177.

${ }^{26}$ Papp 2010a. 261.

${ }^{27}$ Hajnóczy 3.

${ }^{28}$ Kristó 171-172.

${ }^{29}$ Kuncz 1937a. 2.
} 
fejlődésük csúcspontján már fellelhetőek a szervezetiség (vezető-irányító testületek), valamint a tagok egymásközti viszonyai szabályozásának csírái. ${ }^{30}$

Hazánkban a céhek első nyomait már az Árpád-házi királyok korából megtaláljuk. ${ }^{31}$ A céhlevelek elsősorban a mindennapi müködés alapelveit fektették le, de a céh tagjainak halála esetére is tartalmaztak bizonyos rendelkezéseket. Több céhlevél is elöírta, hogy a céh tagjai jelenjenek meg az elhunyt céhmester temetésén, el kellett kísérni őt utolsó útjára, így pl. a lőcsei paszományosok (1492), ${ }^{32}$ tímárok $(1544)^{33}$ és a szabólegények $(1546)^{34}$ szabályzata szerint. Több céhlevélben olvasható az a rendelkezés is, ha egy mester meghalt, az özvegye folytathatta elhunyt férjének a kézmüvességét, ebben az esetben általában hagyni kellett neki egy legényt, ${ }^{35}$ de ezt nem mindegyik céh követelte meg. ${ }^{36} \mathrm{E}$ szabálynak a sajátos továbbélését, pontosabban megjelenését figyelhetjük meg az Evc. tv. 17. § (1) bekezdésében, ami szerint további meghatározott feltételek fennállása mellett az egyéni vállalkozó halála esetén az egyéni vállalkozó özvegye, özvegy hiányában vagy annak egyetértésével örököse folytathatja az egyéni vállalkozói tevékenységet.

A céhek formai szempontból egészen az 1872. évi VIII. tc. hatályba lépéséig fennmaradtak, „helyükben az ipartársulatok keletkeztek, majd a kartelek és szakszervezetek erösbödtek meg." 37

Magyarországon a közkereseti társasági formára emlékeztető személyegyesülés első megjelenése a Fugger- és a Thurzó-család által létrehozott társaság volt, amelynek céljául a felvidéki és erdélyi ezüst-, réz- és sóbányák kiaknázása és a bányászati termékek kereskedelme volt kitüzve, ${ }^{38}$ magának a közkereseti társasági típusnak is az egyik előzménye a Fugger-család egyik tagjának halála után keletkezett rokonok közti társasága. ${ }^{39}$

A kereskedelmi társaságokra vonatkozó kodifikációs szabályozásra a XVIII. századig várni kellett: 1779-ben a királyi Curia kapott megbízást egy kereskedelmi- és

\footnotetext{
${ }^{30}$ Kelemen 45.

${ }^{31}$ Hajnóczy 3.

${ }^{32}$ Hajnóczy 6.

${ }^{33}$ Hajnóczy 11.

${ }^{34}$ Hajnóczy 18.

${ }^{35}$ Hajnóczy 12., Uo. 42., Gerendás 45.

${ }^{36}$ Magyar nyelvű céhlevelek (1525-1682) 146., Uo. 149.

${ }^{37}$ Pozsár 205.

${ }^{38}$ Török T. 2015. 116.

${ }^{39}$ Kuncz 1937b. 32.
} 
váltótörvény kidolgozására. A Skerlecz Miklós vezetésével elkészített javaslatot az országgyülés ugyan megvitatta, de a javaslat nem emelkedett törvényerőre, azt végül csak kinyomtatták, ${ }^{40}$ ezt a javaslatot használták fel a későbbi szabályozási kísérleteknél (pl. 1827. évi 8. tc.-kel kiküldött kodifikációs bizottság, a négyrészes javaslat közül a második tartalmazta többek között a kereskedelmi társaságokra irányadó szabályokat). ${ }^{41}$

\subsection{Az 1839/1840. évi országgyülés kereskedelmi tárgyú törvényei}

A fokozatos gazdasági fejlődés hatására azonban végül elengedhetetlenné vált bizonyos - főképp kereskedelmi jellegü - viszonyok rendezése, a vonatkozó szabályok megalkotására bizottságot küldtek ki, ennek eredményeként születtek meg az 1839-1840. évi országgyülésen a kereskedelmi jellegű törvények, szintén a sikertelen kodifikációs kísérletek felhasználásával. ${ }^{42}$ (Ezek a törvények az 1840. évi 15. tc. a váltótörvénykönyv, az 1840. évi 16. tc. a kereskedőkröl, az 1840. évi 17. tc. a gyárok jogviszonyairól, az 1840. évi 18. tc. a közkeresetre összeálló társaságok jogviszonyairól, az 1840. évi 19. tc. a kereskedői testületekről és az alkuszokról, az 1840. évi 20. tc. a fuvarosokról, az 1840. évi 21. tc. az adóssági követelések elsőbbség végetti betáblázásáról és az 1840. évi 22. tc. a csődületről.)

A kereskedőkről szóló törvény 1 . §-a meghatározta, hogy a törvény előtt csak az minősült rendes kereskedőnek, aki kereskedési címét (Handlungsfirma) a törvényi szabályozás alapján bejegyeztette és a kereskedéséről rendes könyveket vezetett. Egyúttal megjelölt egy kört, ki nem válhatott kereskedővé. ${ }^{43}$

\footnotetext{
${ }^{40}$ Homoki-Nagy 150.

${ }^{41}$ Papp 2011b. 18., Papp 2010a. 264., Horváth 2004. 7-8.

42 Papp 2011b. 18., Papp 2010a. 267., Sándor T. 2014a. 17.

43 1840:15. tc. 2 . $\S$

„Rendes kereskedést azonban nem nyithatnak, s magokat mint kereskedőket be nem jegyeztethetik:

a) Azok, kik 20-dik évöket el nem érték;

b) Bármelly vallás papjai, s a szerzetesek;

c) Valóságos szolgálatban levő katonai személyek;

d) Az alkuszok (Sensalen, proxenetae);

e) Kik csődület és bukás (Falliment) alá kerülvén, a csődületi biróság itélete által rendes kereskedés üzésétől eltiltattak;

f) Kik csalási bünök miatt megfenyíttettek;

g) Kik elmebeli fogyatkozásuk miatt törvényes gondviselés alatt állanak;

h) A $d$ ) e) és $f$ ) pontok alatt előszámlált személyek feleségei;

i) Ezeken kivül sz. kir. városokban addig, míg e részben a törvényhozás kimerítőleg rendelkezik, a kereskedésnek elkezdhetésére nézve az eddigi gyakorlat fog megtartatni."
} 
A kereskedés joga megszünt a kereskedő halálával. ${ }^{44}$ Ebben az esetben a törvényes örökösök vagy az ő megbízottjaik, amennyiben az örökösök nem kívánták folytatni a kereskedelmi tevékenységet, minden függő kereskedési ügyet be kellett, hogy fejezzenek, újabbat nem kezdhettek, a megmaradt árut el kellett adni, és a hitelezők igényeit ki kellett elégíteni. A képviselet vonatkozásában vélelmet állítottak fel: az örökösök által a kereskedés rendbe szedésével megbízott aláírási címvezetőt úgy tekintették, mintha az elhunyt kereskedő bízta volna meg az aláírási cím vezetésére. ${ }^{45}$ A törvény ebbéli megfogalmazásából kiderül, hogy a törvényes örökösök folytathatták jogelődjük tevékenységét.

\subsection{A kereskedelmi jog öröklési vetületének megjelenése}

\subsubsection{A kereskedelmi kódex szerint}

A polgári kori magyar kereskedelmi jog egyik legfontosabb forrása az 1875. évi XXXVII. tc., a kereskedelmi törvény (a Kt.) volt. A törvény kodifikációs munkálatai 1872-ben kezdődtek el, a törvényjavaslat 1875-ben került az országgyülés elé, majd annak elfogadása után 1876. január 1-jén lépett hatályba. ${ }^{46}$ Kétségtelen, hogy a Kt. megalkotásakor mintának tekintették a német kereskedelmi törvénykönyvet (kivéve a betéti részvénytársaság és a csendestársaság vonatkozásában, amiket nem szabályoztak ebben a törvényben, utóbbinak e néven történő kodifikálására is csak az 1930. évi V. tc.-ben került sor) és nem minősíthető a magyar társasági jogi jogalkotás szerves folytatásának sem (nem támaszkodott a kodifikációs kísérletek eredményeit ötvözö 1840:18. tc.-re). Elévülhetetlen érdeme viszont a kereskedelmi jog zárt, egyetemes jellegü jogággá alakítása és biztos ítélkezési alap nyújtása a bírói gyakorlat számára. Társasági jogi szempontból eleget tett a kiegyezés utáni gazdasági követelményeknek a társasági formációk részletes szabályozásával. ${ }^{47}$ Ha valamilyen kérdésről a törvény nem rendelkezett, akkor a kereskedelmi szokások voltak az irányadóak, a kisegítő jogforrás szerepét az általános magánjog töltötte be. ${ }^{48} \mathrm{Ez}$ a kódex teljes egészében 1945-ig

\footnotetext{
${ }^{44} 1840: 16$. tc. $57 . \S$ a) pont

45 1840:16. tc. 58. §

${ }^{46}$ Papp 2011b. 19., Mezey (szerk.) 194., a kereskedelmi kódex kodifikálására lásd még Mohai $2016 a$. 111-114.

${ }^{47}$ Papp 2011b. 19-20.

${ }^{48}$ Kt. 1. §, Horváth 2006. 388., Mezey (szerk.) 197-199.
} 
határozta meg a magyar társasági jog fejlődését, ezután az ideológiának megfelelően folyamatosan vesztette hatályát. ${ }^{49}$

\subsubsection{A kereskedö utáni öröklés; a kereskedelmi társaságokról általában}

A Kt. szerint kereskedőnek az minősült, aki a saját nevében kereskedelmi ügyletekkel iparszerüleg foglalkozott. ${ }^{50}$ A 4 . $§$ a kereskedőkre vonatkozó szabályokat kiterjesztette a kereskedelmi társaságokra, a kereskedelmi társaságok tehát kereskedőnek minősültek, ${ }^{51}$ éppen ezért fontos, hogy a kereskedőket érintő szabályokat röviden áttekintsük, különösen azért is, mert több, az örökléssel összefüggésben lévő kérdés merült fel a gyakorlatban.

A kereskedelmi társaságok a kereskedőkhöz hasonlóan az ún. cég alatt fejtették ki tevékenységüket. Ez a Kt. 10. §-a szerint nem más, mint azon név, amely alatt a kereskedő üzletét folytatja, s amelyet aláírásul használ. A kereskedelmi társaságok cégjük alatt jogokat szerezhettek, kötelezettségeket vállalhattak, ingatlanon tulajdont és egyéb jogokat szerezhettek, perelhettek és perelhetők voltak. ${ }^{52}$ Közkereseti társaság és betéti társaság létrehozását be kellett jelenteni annál a törvényszéknél, amelynek illetékességi területén a társaság székhelye van, valamint annál a törvényszéknél is be kellett jelenteni, ahol fióktelepe volt. ${ }^{53}$ A részvénytársaság megalakulásának egyik feltétele volt a cégjegyzékbe bevezettetés, ${ }^{54}$ és a korlátolt felelősségű társaságot is be kellett jegyeztetni annál a cégbíróságnál, amelynek területén a társaság székhelye volt. ${ }^{55}$ Ha valaki egy létező kereskedelmi üzletet szerződés vagy öröklés útján szerzett meg, azt a volt tulajdonos vagy jogutódainak beleegyezésével az addigi cég alatt az utódlást kifejező toldással vagy anélkül folytathatta. ${ }^{56} \mathrm{~A}$ Kt. ezzel áttörte a cégvalódiság elvét a származékos cégnél, ${ }^{57}$ ugyanis a cégnévben a valóságnak megfelelő adatokat kellett feltüntetni, de ha nem volt utódlásra való utalás a névben,

\footnotetext{
${ }^{49}$ Török T. 2015. 118.

${ }^{50}$ Kt. 3. $\S$

51 Réti 101.

${ }^{52}$ Kt. 63. §, Kfttc. 6. §

${ }^{53}$ Kt. 65. §, Kt. 126. §, Kuncz 1937b. 30-34., Kuncz 1937b. 157-158., Kuncz 1937b. 191. A kereskedelmi cégjegyzékekre vonatkozó szabályokat a földmüvelési-, ipar- és kereskedelemügyi, valamint az igazságügyi miniszter együttes rendelete határozta meg ,a kereskedelmi czégjegyzékek berendezése és vezetése tárgyában" a Magyarországi rendeletek tárában 1875-ben 137. szám alatt kiadott rendeletben.

${ }^{54}$ Kt. 149. §, Kuncz 1937b. 36., Kuncz 1937b. 226.

${ }^{55}$ Kfttc. 7. \&, Kuncz 1937b. 375.

${ }^{56} \mathrm{Kt} .12 . \S$

${ }^{57}$ Kuncz 1937a. 105.
} 
akkor azt lehetett hinni, hogy még mindig a cég eredeti tulajdonosa volt az, aki az üzletet vitte.

Az 1922. évi XII. tc. (az 1884. évi XVII. tc., az ipartörvény novellája) 56. §-a további részletszabályokat tartalmazott a cég elnevezésére vonatkozóan, így például az iparos üzlethelyiségét annak külső részén cégtáblával köteles volt megjelölni. A cégtáblán fel kellett tüntetni az üzlettulajdonos családi és utónevét úgy, hogy egyik rész se legyen kevésbé szembeötlő, mint a többi. Ha az üzlettulajdonos férjezett, vagy özvegy nő volt, a cégtáblán férje nevét köteles volt megfelelő toldással feltüntetni. Ehhez kapcsolódott az, hogy az özvegy fel volt jogosítva elhunyt férje vezetéknevét cégnévként használni, de egyértelmüen ki kellett derülnie, hogy a cégtulajdonos már nem a férj. ${ }^{58}$ Abban az esetben, amennyiben az osztályos egyezség szerint a hagyatékot az özvegynek adták át, és a többi örökös az ellen nem tiltakozott, hogy az özvegy a hagyatékához tartozó üzletet az addigi cég alatt folytassa, a cég egyedüli tulajdonosaként az özvegyet kellett bejegyezni. ${ }^{59}$

A kereskedelmi társaságok mellett az ilyen formában nem müködő, „egyszerü” kereskedők halála is ugyanúgy alanyváltozást eredményezett, ugyanis a halál, miután jogok és kötelezettségek alanya csak élö, jogképes személy lehet, megszüntette a kereskedői minőséget, de az örökösök a cég törléséig az alatt - átmenetileg - még felléphettek. ${ }^{60}$

Kuncz Ödön szerint ${ }^{61}$ a régi cég változatlan használata bizonyos előfeltételektől függött:

a) Szükséges volt a volt tulajdonosnak vagy jogutódjának beleegyezése, ezt pedig a bíróságnál igazolni kellett. Beleegyezésre jogosult személynek minősült: 1 . a volt tulajdonos, 2. az ő valamennyi örököse (ha az üzletet az örökösök folytatták, csak az örökösi minőséget kellett igazolni; ha egy örökös folytatta, a többi örökös beleegyezése volt szükséges, kivéve, ha a végrendelet őt jelölte ki utódnak; ha egyéni céget több örökös folytatott, azt a társascégek jegyzékébe kellett átvezetni változatlan cég alatt); de a beleegyezés lehetett hallgatólagos is. Ha az örökösök a vállalatot teljes felszereléssel és terheivel egyik társuknak osztályegyezség alapján adták át, és nem

\footnotetext{
${ }^{58}$ Bp. T. 3493/1901. (Szende 48.)

${ }^{59}$ Bp. T. 6122/1917. Hj. Dt. XII. 30. (Szende 53.)

${ }^{60}$ C. $1442 / 1895$. (Szende 28.)

${ }^{61}$ Kuncz 1937a. 107-108.
} 
tiltakoztak az üzlet addigi cég alatt folytatása ellen, beleegyezésüket meg lehetett állapítani. $^{62}$

b) Szükséges volt, hogy az új tulajdonos az üzletet meg is szerezze.

c) További előfeltételnek számított az, hogy a tulajdonos-változás idejében ne szakadjon meg az üzlet folyamatossága.

d) A megszerzett cégnek bejegyzett cégnek kellett lennie, ugyanis be nem jegyzett céget nem lehetett átruházni. ${ }^{63}$

e) A volt tulajdonos törlése és az új tulajdonos bejegyzése a cégjegyzékbe.

A hagyaték átadása elött az összes öröklésre hivatott személy beleegyezése kellett a régi cég törléséhez. Megegyezés hiányában a hagyatéki eljárás végleges rendezéséig a céget a tag halála előtti állapotban kellett fenntartani: annak sem volt helye, hogy a régi céget valamelyik öröklésre hivatott akár csak toldatként is bejegyeztesse. ${ }^{64}$

Nem elégséges az öröklés folytán bekövetkező alanyváltozásnak a társaságon belül történő elrendezése, az is fontos, hogy a kívülálló harmadik személyekkel szemben mikor lehetett hivatkozni az öröklésre: az örökhagyó cégtulajdonossal egy személynek tekintendö örökösök a cég tulajdonosa személyében örökösödés címén beállott változást harmadik személy ellen csak annyiban érvényesíthették, amennyiben a harmadik fél e változásról tudomással bírt. ${ }^{65}$

Erről rendelkezik a Kt. 19. § is: ha a cég megváltozott vagy megszünt, vagy birtokosai személyében változás történt, akkor ezt a tényt be kellett jelenteni a kereskedelmi cégjegyzékbe történő bevezetés és kihirdetés végett. Amennyiben a cég megváltozását vagy megszűnését a kereskedelmi cégjegyzékbe nem jegyezték be, és nem hirdették ki, az a személy, akinél az érintett tények bekövetkeztek, harmadik személlyel szemben csak akkor hivatkozhatott erre, ha tudta igazolni, hogy ezek a tények a harmadik személy számára ismertek voltak.

Tehát „,a Kt. 12. §-a szerint az üzletet örökölni is lehet. A tárgyi értelemben vett üzlet szervezet és biztosított kelendőség. Üzlet öröklése esetén több kérdésre kell megoldást találni. A kereskedés joga nem tárgya az öröklésnek. Az örökös az üzlet továbbfolytatásával lesz kereskedő. Az örökös köteles az üzlet értékét konzerválni (az üzletet folytatni vagy eladni), különösen akkor, ha az üzlet hagyomány vagy

\footnotetext{
${ }^{62}$ B. T. 6122/1917. P. H. D. XII. 30. (Szende 53.)

63 838. E. H., C. P. IV. 3673/1929., idézi Kuncz 1937a.

${ }^{64}$ C. $133 / 1918$. (Szende 53.)

${ }^{65}$ Pozsonyi T. 68/1900. (Szende 44.)
} 
utóörökösödés tárgya. Az örökös a hagyatéki hitelezőnek akkor is csak a hagyaték erejéig felel, ha üzletet örököl. Abban az esetben azonban, ha elmulasztja az üzlet értékének konzerválását, a vétkességre visszavezethető elértéktelenedésért egész vagyonával felel a hitelezők felé. Az örökösi osztálynál sem szükséges az üzleti vagyon szétosztása (maradhat az üzlet, mint egész, egy vagy több öröktárs kezében).” Kuncz Ödön 1937-es sommás megállapítása szerint „,mindenesetre szükséges volna az üzlet öröklésének külön szabályozása.",66

\subsection{A kereskedelmi jog öröklési vetülete speciális jogszabályok szerint}

Az első ipartörvény, az 1884. évi XVII. tc. 40. § szerint az iparos halála esetén annak özvegye újabb bejelentés nélkül folytathatta az üzletet. Engedélyhez kötött iparoknál azonban „személyes megbízhatóságát” az iparhatóság előtt igazolnia kellett. Ha nem maradt özvegy, vagy ha az özvegy e jogával nem akart élni, az üzletet a kiskorú gyermekek vagy unokák javára lehetett folytatni.

A már hivatkozott iparnovella arra vonatkozóan is tartalmazott rendelkezéseket, hogy a kétségtelenül a kereskedelmi jog körébe vonható iparos halála esetén miképp lehetett folytatni az ő tevékenységét. A 7. § szerint az iparos halála után az életben maradt házastárs a saját jogán, amennyiben az iparos után törvényes, törvényesített vagy örökbefogadott kiskorú gyermekek vagy unokák maradtak, ezeknek a jogán és ezek javára is újabb iparigazolvány, illetőleg iparengedély nélkül folytathatta az iparos által gyakorolt ipart. Az üzlet átvételét kötelessége volt azonban az iparos halálától számított három hónap alatt az iparhatóságnak bejelenteni és mindazokat a kellékeket saját személyében igazolni, amelyeket a törvény az örökhagyó által folytatott ipar gyakorlásának előfeltételeképpen megszabott, kivételt képezett ez alól a törvényben megállapított szakképzettség. Külön rendelkezések vonatkoztak arra az esetre is, ha az özvegy nem rendelkezett a szükséges szakképzettséggel. ${ }^{67} \mathrm{Az}$ elhunyt iparos iparát az életben maradt házastárs haláláig folytathatta, nem szünt meg ez a joga abban az esetben sem, ha új házasságra lépett. ${ }^{68}$

\footnotetext{
${ }^{66}$ Kuncz 1937a. 80.

${ }^{67}$ 1922:XII. tc. 7. § (2) bek., 8. § (2) bek.

${ }^{68}$ 1922:XII. tc. 7. § (3) bek.
} 
Természetesen az is elöfordulhatott, hogy a meghalt iparosnak nem volt életben lévő házastársa, vagy az életben maradt házastárs utóbb meghalt, illetve a fent leírt jogával nem kívánt élni. Ebben az esetben az ipart a gyám, illetőleg az életben maradt házastárs az iparos törvényes, törvényesített vagy örökbefogadott kiskorú gyermekei vagy unokái javára, ezek nagykorúvá válásáig újabb iparigazolvány, illetőleg iparengedély nélkül folytathatta. ${ }^{69} \mathrm{Ha}$ a gyám vagy az életben maradt házastárs ezekkel a feltételekkel saját személyében nem rendelkezett, az ipart a kiskorúak javára csak üzletvezető alkalmazásával folytathatta. ${ }^{70}$

Különbségként állapítható meg az eredeti törvény és a novella között, hogy az 1884-es törvény szerint még nem kellett bejelenteni az ipar folytatását, míg később ezt már meg kellett tenni.

Az özvegy nő számára különleges jogokat biztosítottak a törvények, amelyek alapjául a szerves fejlődésen keresztül ment özvegyi jog szolgált. Ide tartozott például az, hogy a Kt. alapján a férj iparát özvegyi jogon folytató s a férj vagyonán haszonélvezeti joggal rendelkező özvegy az üzlethez tartozó ügyleteknek saját nevében történő megkötésére volt jogosult. ${ }^{71}$ E kategóriához tartozott az is, amikor az elhunyt férjnek gyógyszertári jogosítványa felett szerzett haszonélvezetet az özvegy. Az 1876. évi XIV. tc. 132. § szerint a gyógyszerész elhunytával a személyes gyógyszerészeti jogosítvány haszonélvezete az özvegyre szállt. Ha az özvegy gyermekei kiskorúsága alatt újra férjhez ment, vagy meghalt, a jogosítvány haszonélvezete a gyermekek nagykorúságáig a gyermekekre szállt át. A Curia egy eseti döntése szerint, ${ }^{72}$ ha haszonbérbe adták a jogot, akkor a haszonbér az elhalt személy jogutódjait illette meg, az nem szolgálhatott a hitelezői követelések kielégítésének alapjául. Jancsó György meglátása alapján ${ }^{73}$ ez a legfőbb szinten történt döntés helytelen, mert eszerint a tartozások nem szállnának át az örökösökre. A gyógyszerészet joga nem olyan jog, amely olyan szorosan tapadt a jogosulthoz, hogy annak halálával ez is megszünt volna, hanem a törvény szerint is megvalósulhatott az utódlás, ezáltal a tartozások is öröklödtek. Ugyanis nem kerülhetett hátrányosabb helyzetbe egy hitelező csak azért, mert követelését nem hajtotta be az adós életében,

\footnotetext{
${ }^{69}$ 1922:XII. tc. 8. § (1) bek.

${ }^{70}$ 1922:XII. tc. 8. § (2) bek.

${ }^{71}$ C. $2162 / 1934$. In: Kuncz 1937a. 67.

${ }^{72}$ Curia 4765/1883. sz. (Jancsó 900.)

73 Jancsó 900-903.
} 
ezáltal elveszítve követelését, holott a tartozás fedezésére egy igen jól jövedelmező gyógyszertár volt található a hagyatékban.

Ez a jogosítvány az özvegyasszonyt az özvegyi jog alapján illette meg, azonban ez a férjet nem illette meg, ha például az asszony volt egy személyes jogú gyógyszertár tulajdonosa, tehát a férj nem nyerhetett e felett haszonélvezetet. ${ }^{74} \mathrm{~A}$ törvényi szabályozás és az irodalmi álláspont alapján a gyógyszerészet kívül esett a kereskedő szabályozásán, azonban annak személyhez kötött jellegében (a szakismeret folytán is) hasonlított ahhoz. Másrészt a gyógyszerészek által szabályszerüen vezetett és bélyegzett üzleti könyvek a többi kereskedelmi könyvhöz hasonló bizonyítási erővel bírtak, ${ }^{75}$ ez az erő a Kt. 31. § (1) bekezdése szerint azt jelentette, hogy a kereskedelmi ügyletekből eredő perekben rendszerint nem teljes, eskü vagy más bizonyítási eszköz által kiegészíthető bizonyítékot képeztek. Álláspontom szerint helyes volt a jogtudós véleménye, a gyógyszerészet hasznosításából eredő haszonbér ebben az esetben is a hagyatékba tartozó vagyontárgyat képezett, a hagyatéki tartozások kielégítésére szolgált.

\subsection{Az öröklési jog megjelenése az egyes kereskedelmi társaságoknál}

A kereskedelmi társaságok alapját képező üzletet $K u n c z$ szerint háromféle szempontból is lehetett nézni: mint a forgalom tárgyát, mint vagyonösszességet, és mint jogok és kötelezettségek hordozóját. Ha az első szempont alapján vizsgáljuk az üzletet, mint a forgalom tárgyát, akkor az üzlet átruházásáról, örökléséről, stb. lehetett beszélni, ezek a magánjog szerint pedig csak dolgok vagy jogok tekintetében lehetségesek, az üzlet azonban nem tartozik e kategóriák alá. A fogalomhoz akképp lehetett jutni, ha azt kérdeztük, mit vesz meg az üzlet átvevője, azaz mi a vételár ellenértéke. „Az ellenérték nem más, mint egyrészről: jövedelmet (hasznot) hajtó foglalkozást biztosító és elősegítő szervezet, másrészről biztosított árusító lehetőség (jövedelmezőség). Az üzlet tehát önállóan szervezett vagyonszerző alkalom." ${ }^{, 76} \mathrm{Az}$ üzletet, mint a dologi forgalom tárgyát is fel lehetett fogni: az üzletet el lehetett adni, örökölni, haszonélvezet tárgyává tenni, bérbe adni, zálogba adni és végrehajtani is

\footnotetext{
${ }^{74}$ Uo.

75 1876. évi XIV. tc. 127 . § (2) bek.

${ }^{76}$ Kuncz 1937a. 74-75.
} 
lehetett. ${ }^{77}$ Kuncz megfogalmazásából az következtethető ki, hogy elválasztja egymástól a gazdasági társaságot, mint a kereskedelemben megjelenő szereplőt, és az üzletet, ami a tagokat megillető jogok és terhelö kötelezettségek összessége. Az elválasztás mellett párhuzamot is vont a két fogalom között, amivel a kettő közötti különbséget relativizálta.

\subsubsection{A közkereseti társaság}

A kereskedelmi társaságok legrégebbi alakzata a közkereseti társaság, a történeti fejlődés folyamán csak később jelentkezett igény a korlátozott tagi felelösségre (pl. a részvénytársaságra). A személyek szerződéses egyesülésén túl közkereseti társaság keletkezhetett úgy is, ha az egyéni cég tulajdonosának halála után az örökösök az üzletet ugyanazon cég alatt folytatták. ${ }^{78}$ A közkereseti társaság első magyarországi szabályozását az 1840. évi 18. tc.-ben találhatjuk, ezt a törvény szoros értelemben vett közkereseti társaságnak is nevezte. A törvényben elfoglalt jelentős pozícióját, példamutatását mintázta, hogy legrészletesebben ezt a társasági formát szabályozta. $(2-22 . \S, 36-42 . \S, 48-53 . \S)^{79}$

Az 1840. évi 18. tc. $1 . \S$ határozta meg a törvény hatálya alá tartozó társaságok (közkereseti társaság, csendes társaság, részvénytársaság) fogalmait, eszerint a kkt. olyan társaság, amely ,tagjainak a nevét a cégnévben feltüntetik, vagy az ahhoz füzött "és társak" (et Comp.) elnevezésben szerepelnek, s a társaságnál minden egyes tag egész vagyonával kötelezve vagyon a társaságnak külső személyekkel kötött szerződéseire nézve.” A törvény $37 . \S$ a) pontja alapján a tag tagsági jogviszonya megszünt a tag halálakor. Az örökösök, ha a társasági szerződés nem rendelkezett erről, a társaság folytatására sem jogosultak, sem kötelezettek nem voltak. Ha a társasági szerződés rendelkezett erről a kérdéskörről, akkor is csak az ún. közvetlen örökösök, tehát az elhunyt tag örökösei, nem pedig az örökösök örökösei folytathatták a társaságot. Amennyiben nem tartalmazott a társasági szerződés a tag halála vonatkozásában megengedő rendelkezést, akkor az örökösök nem válhattak az örökhagyó jogán a társaság tagjává. Ugyanakkor, mint a társaság szempontjából nézve kívülálló személyek, az örökösök az 1840. évi 18. tc. 20-22. § rendelkezései alapján is

\footnotetext{
${ }^{77}$ Kuncz 1937a. 78.

${ }^{78}$ C. $81 / 1916$. Azonos következtetésre jutott a C. 1163/1919., valamint a C. 429/1922. számú ügyekben a Curia. (Szende 156.)

${ }^{79}$ Papp 2010a. 267.
} 
beléphettek, ekkor azonban külön vagyoni hozzájárulást kellett teljesíteniük. A tag halálának a társaság létezésére is hatása volt, ugyanis megszünt a társaság, ha meghalt az a tag, akinek személyes részvételéhez a társaság a saját fennmaradását kötötte, vagy ha a társaság tagjainak többsége meghalt. ${ }^{80}$

A kereskedelmi jog következő nagyobb volumenü szabályozására a Kt.-ben került sor, ennek 64. §-a szerint közkereseti társaság keletkezett, ha két vagy több személy kereskedelmi üzletet közös cég alatt, korlátlan, és egyetemleges kötelezettség mellett folytatott. Egy 1900-as döntés szerint a közkereseti társaság keletkezésének és létezésének nem volt előfeltétele a cég bejegyeztetése. ${ }^{81}$ A társasági jog és az öröklési jog kapcsolata különösen a társaságok megszünésénél bírt jelentőséggel. A Kt. 98. § 2 . pontja alapján fő szabály szerint a közkereseti társaság feloszlott, ha valamelyik tagja meghalt, amennyiben a szerződésben nem kötötték ki, hogy a társaságot az elhunyt tag örököseivel folytassák. A törvény taxatíve megállapította azokat az okokat, amelyek a közkereseti társaság feloszlását közvetlenül - ipso facto - eredményezték, azaz a feloszlás és annak következményei azonnal beálltak, amint a kérdéses ok bekövetkezett, a társaság megszüntetése iránt nem kellett külön keresetet előterjeszteni. Eszerint az azonnali megszűnés volt az általános szabály. ${ }^{82} \mathrm{E}$ rendelkezés a társasági tagok érdekeit célozta megóvni, s így ha a felek érdekeit más módon nem tartották megvédhetőnek, ezt a módot igénybe vehették s mellőzhették a 98. § (2) bekezdésében foglaltakat, ${ }^{83}$ ami szerint az örökösök beléphettek a társaságba. Ezt cizellálta tovább a C. 1384/1903. ${ }^{84}$ döntés, de eszerint a közkereseti társaságnál a törvényben felsorolt feloszlási okok „nem oly kényszerítő természetüek”, hogy azoknak bekövetkezése esetén a társaságnak okvetlenül meg kellett szűnnie. Ha az örökhagyó egy kkt. tagja volt, akkor az örökösök kielégítése két módon valósulhatott meg: rendelkezhettek arról, hogy a jogutódok beléphetnek a társaságba, ekkor az ő döntésüktől függött, részt kívántak-e venni a kereskedelmi társaságban tagként. Ha nem rendelkeztek így a társasági szerződésben, illetve az örökösök akképp döntöttek, hogy nem vesznek részt a további működtetésben, akkor velük el kellett számolni; ez ,vagy akképp történhetik, hogy az elhunyt tag örökösei annak helyébe a társaságba belépnek, vagy akképp, hogy az életben maradt tagok a közkereseti

\footnotetext{
${ }^{80} 1840: 18$. tc. $39 . \S$ d)-e) pont

${ }^{81}$ C. $1002 / 1900$. (Szende 156.)

${ }^{82}$ C. $3190 / 1922$. Hj. Dt. XVI. 77. (Szende 185.)

${ }^{83}$ C. $1413 / 1917$. Hj. Dt. XI. 149. (Szende 186.), Vö. Kuncz 1937b.30.

${ }^{84}$ Szende 185.
} 
társaságot tovább folytatják és az elhunyt örököseit ennek illetménye tekintetében kielégítik." ${ }^{85}$ A társaságra nézve korlátozó szabályt fektetett le az említett döntés, amely szerint az elszámolásra vonatkozó, a társaság számára nyitva álló, az öröklés megnyílásától számított egyéves határidő csak ,időhaladéki kedvezmény”, amelyet a túlélö társasági tagok az elhunyt tag halálának időpontjában irányadó értékalap csorbítása nélkül vehettek igénybe. Ezt a konkrét jogesetben valutaárfolyamváltozásokra próbálták felhasználni.

Ha a társasági szerződés nem intézkedett arról, hogy a közkereseti társaság valamely tagjának elhalálozása esetén a társaságot a túlélő tagok az elhalt tag örököseinek kizárásával egyedül folytathassák, sőt a szerződés az örökösöket az elhalt tag jogainak gyakorlására kifejezetten feljogosította, akkor nyilvánvaló és így peren kívüli eljárásban is megállapítható volt, hogy a túlélő társasági tagoknak nem volt joguk ahhoz, hogy a közkereseti társaságot az elhalt tag örököseinek kizárásával folytathassák. Nem jogosította fel őket erre az özveggyel létrejött megállapodás sem, ha ő csak haszonélvező volt és ilyen megállapodás létesítésére neki sem az önjogú ${ }^{86}$ örökösöktől, sem pedig a nem önjogú örökösök törvényes képviselőitől és a gyámhatóságtól felhatalmazása ${ }^{87}$ nem volt. ${ }^{88}$

A szerződés tehát megállapíthatta azt, hogy a tag halála esetén a társaságot folytassák az örökösökkel. Ebben az esetben az örökös - habár ő ezen a címen csak a hagyaték erejéig volt felelős - mihelyt a társaságba belépett, a társasági tartozásokért korlátlanul felelös. Ha a tag halála miatt a társaság feloszlott, az elhalálozott tag örökösei nem a Kt., hanem az öröklési jog szabályai szerint (tehát csupán az elhunyt egész hagyatéka erejéig) feleltek a társasági tartozásokért, tekintet nélkül arra, hogy e tartozások a feloszlás előtt, avagy a felszámolás alatt keletkeztek-e. A Kt. 108. § 2. mondatának az a rendelkezése ugyanis, hogy az elhalálozott tag örökösei közös képviselőt tartoztak a felszámolók közé küldeni, nem volt magyarázható akként, hogy a társaságba be nem lépett örökösök képviselöjének közremüködésével vállalt felszámolás alatti tartozások az örökösöknek, mint a kkt tagjainak tartozásai voltak. Egy örökös örököstársai hozzájárulása nélkül nem volt jogosult a társaság

\footnotetext{
${ }^{85}$ C. 489/1883. (Szende 186.)

86 „Önjogú volt az, aki nem állt másnak magánjogi hatalma (atyai hatalma, gyámsága vagy cselekvőképességet kizáró gondnoksága) alatt.” Mezey (szerk.) 168.

87 1877:XX. tc. 20. § b) pont, 113. § 6. pont

${ }^{88}$ C. $4357 / 1920$. Hj. Dt. XIV. 6. (Szende 186.)
} 
jogügyleteinek megtámadására. ${ }^{89}$ Ha az örökösök az életben lévő társasági tagnak a társaság azonnali felszámolásához és a végkiegyenlítéshez való jogos érdekét jogellenesen és vétkesen megsértették, a kárt az egész vagyonuk erejéig megtéríteni volt kötelesek. ${ }^{90}$

Mindezeket összegezte a Kúria P. IV. 2423/1937. számú ítélete, ami szerint a társasági tagság átszállására, amely mint személyes jog és kötelezettség, csak a Kt. 98. §-ának 2. pontjában említett előzetes megállapodás esetében lehet öröklés tárgya, az ipso iure öröklés elve nem volt alkalmazható. Az öröklési jog alapelve az, hogy az örökös a hagyatéki tartozásokért sohasem felel a hagyaték értékén felül, a felelössége tehát a törvény erejénél fogva korlátozott. Ezzel áll szerves összefüggésben az a másik alapelv, hogy az örökséget a jogosult ipso iure szerzi meg, ami annyit jelent, hogy az örökléshez külön elfogadási nyilatkozat nem szükséges, elég, ha azt a jogosult nem utasítja vissza. Mindehhez képest a közkereseti társaság tagjai a társasági kötelezettségekért egész vagyonukkal egyetemlegesen felelősek és ez a felelősség kiterjed nemcsak azokra a tagokra, akik az illető kötelezettség elvállalása időpontjában már a társaság tagjai voltak, hanem azokra is, akik csak később léptek valamely fennálló közkereseti társaságba, tehát az elhunyt tag belépő örököseire is, akik ennél fogva harmadik személyek irányában már nem az öröklési jog szabályai, hanem a Kt. értelmében voltak felelősek. A felelősségi mérce eltérő szabályozásából következett, hogy az örökösnek csak joga volt, de nem kötelezettsége, hogy a néhai jogelődje helyett a közkereseti társaságba belépjen, ha azt a társasági szerződés megengedte. E jog gyakorlásához az örökös megfelelő akaratnyilvánítása szükségeltetett, mert a társasági tagság átszállása az örökösre hárult hagyaték értékét meghaladó kötelezettségek forrása lehetett, ilyen kötelezettségek vállalása pedig ipso iure az örökös elfogadó (belépési) nyilatkozata nélkül nem volt lehetséges. Az alapügybeli felperesek ilyen nyilatkozatot a halálesettől számított 10 évet meghaladó időn át nem tettek, az ítélet szerint az időmúlásra tekintettel e jogukról lemondtak. ${ }^{91}$ Ehhez képest az irodalomban megjelent álláspont ${ }^{92}$ kifogásolta ezt a típusú jogvesztést, az egyébként bizonyos tekintetben hatályos jogunkban továbbélő jogtételt (a belépéshez szükséges az örökösi nyilatkozat), mert a szerző szerint az öröklés tényével az örökös szükségképpen a társaság tagjává kellett, hogy váljon, különben az a társaság hitelezői

${ }^{89}$ C. P. IV. 9263/1927. (Kuncz 1937b. 177-178.)

${ }^{90}$ C. P. IV. 2285/1934.; Kuncz 1937b. 177-178.

${ }^{91}$ t.t. 529-530.

${ }^{92}$ Uo. 
számára is hátrányt jelenthetett. Állításának alátámasztására német jogtudósok álláspontját hívta segítségül, illetve az 1897. évi német kereskedelmi törvény 139. §ának rendelkezését idézte, ami szerint az örökösnek lehetősége volt azonnali (rögtönös) hatályú felmondásra abban az esetben, ha a közkereseti társaságot nem alakították át betéti társasággá oly módon, hogy abban az örökös vált kültaggá. Ez az álláspont ugyanakkor nem vette figyelembe kellő mértékben a törvényi szabályozást és az ahhoz kapcsolódó bírói gyakorlatot.

\subsubsection{A betéti társaság}

A betéti társaság első magyar törvényi fogalma a Kt. 125. §-ában található meg, eszerint betéti társaság keletkezett, ha közös cég alatt folytatott kereskedelmi üzletnél a társak közül egy vagy több (kül)tag csak kikötött vagyonbetételével volt felelős, míg ellenben egy vagy több (bel)tagot korlátlan és egyetemleges felelősség terhelt; a beltagokra nézve, ha ezek többen voltak, a társaság közkereseti társaságként is minősült. A fogalom deklarálta azt a mai napig fennálló viszonyt a közkereseti és betéti társaság között, ami szerint a betéti társaságra a közkereseti társaság szabályait kellett megfelelően alkalmazni, ha a törvény másképp nem rendelkezett.

A halál esetén történő átszállás vonatkozásában azt lehet megállapítani, hogy a tagsági jogok öröklés útján is átszállhattak, de csak ha a tagságbeli jogutódlás lehetőségét a társasági szerződésben kikötötték. ${ }^{93}$

A halál kilépésnek minősült, miután: „kilépés alatt úgy az önkéntes, mint a szükségképpeni kiválás értendő, tehát nevezetesen valamely tag halála, rendelkezési képességének elvesztése, csődje éppen úgy, mint felmondása."94 Az elhunyt tagra eső vagyon megállapításánál a társasági üzletnek, mint szervezetnek értékét is figyelembe kellett venni a társasági vagyonban lévő összes vagyontárgyak pénzben kifejezett értékének hányadán felül, ${ }^{95}$ továbbá az is, amelyet a tagnak a társaság és a cég eszmei értékében való részesedése jelentett. ${ }^{96}$ Ha valamelyik tag kilépett vagy őt kizárták a társaságból, az elszámolás alapja a kilépéskor, illetőleg a kizárás iránt indított kereset kézbesítésekor fennálló vagyoni helyzet volt. A kilépett (vagy kizárt) társasági tag a későbbi ügyletekben, jogokban és kötelezettségekben csak annyiban részesült,

\footnotetext{
${ }^{93}$ Horváth 2006. 407.

${ }^{94}$ Nagy F. 300.

${ }^{95}$ C. $3679 / 1927$. Hj. Dt. XXI. 14. (Szende 198.)

${ }^{96}$ C. $5291 / 1924$. Hj. Dt. XIX. 11. (Szende 197-198.)
} 
amennyiben azok a korábban kötött ügyletekből eredeztethetőek voltak, ez azt jelenti, hogy az örökösök igényt tarthattak, illetve kötelezettségük keletkezett az elhunyt tagra eső rész vonatkozásában. ${ }^{97}$

Az öröklési jog egyik legfontosabb kérdése az, miképp tartoznak felelősséggel az örökösök jogelődjük tartozásaiért. A betéti társaságok esetén meg kellett különböztetni a tagokat aszerint, hogy beltagok vagy kültagok voltak a társaságban. A beltagok eltérő rendelkezés hiányában úgy feleltek, mint a közkereseti társaság tagjai, már csak azért is, mert - a korábbiakban hivatkozottak alapján - belső viszonyukban közkereseti társaságnak kellett őket tekinteni. ${ }^{98}$ A kültag a társasági kötelezettségekért csak betétével, vagy amennyiben ezt még nem fizette be, a szerződésben meghatározott összeggel volt felelős a társaságnak a befizetésig keletkezett kötelezettségeiért. Az ezzel ellenkező társasági szerződés vagy későbbi megállapodás harmadik személyek irányában nem bírt joghatállyal. ${ }^{99}$

A Kt. 144. § szerint, ha valamely kültag meghalt, vagy szabad rendelkezési jogát (cselekvőképességét) elvesztette, a társaság nem szünt meg, ${ }^{100}$ ezáltal különbséget tett a társaság megszünése vonatkozásában a kétféle tagi minőség között. Ez a különbségtétel azonban nem eredményezett tagok között diszkriminációt, hiszen a beltag(ok) azok, akiknek nagyobb ráhatásuk volt az üzleti ügyvitelre, ők feleltek a társasági vagyon által ki nem elégített követelésekért, a kültagok csak tőkét adtak a társaság alapításához.

A kereskedelmi társaságokat korábban is, ahogy ma is, ${ }^{101}$ létre lehetett hozni mind határozott, mind határozatlan időtartamra. Konkrét társasági szerződésben szerepelt az a rendelkezés: „ha a társaság tartama alatt bármely cégtag elhaláloznék, úgy az életben maradt cégtagok a társaságot az eddigi cég alatt saját számlájukra folytathatják", amely klauzula a Curia döntése szerint csak azt jelentette, hogy az életben maradt tagok a határozott időtartamra alapított társaságot a társaság müködésére meghatározott idő alatt elhunyt tag halála utáni, hátralékos része alatt folytathatták az addigi cég alatt. ${ }^{102}$

\footnotetext{
${ }^{97}$ Kt. $105 . \S$

${ }^{98}$ Kt. $125 . \S(2)$ bek., Kt. 89. §

${ }^{99}$ Kt. 140. §; Kt. 139. § (1) bek.

${ }^{100}$ Lásd még: Nagy F. 331.

${ }^{101}$ Ptk. 3:4. § (5) bek.

${ }^{102}$ C. 1004/1917. (Szende 193.)
} 


\subsubsection{A részvénytársaság}

Alapvetően tőkeegyesítő jelleget felmutató - a személyegyesítő jegyeket pedig gyakorlatilag teljesen mellőző - kereskedelmi társaság a részvénytársaság. A részvénytársaságok első megjelenése szintén az 1840:18. tc.-ben volt, a kkt és a csendestársaság mellett, csak ekkorra valósultak meg azok a feltételek, amelyek szükségesek voltak ahhoz, hogy jelentősebb körben alapíthassanak részvénytársaságok. ${ }^{103} \mathrm{E}$ törvény így határozta meg ezt a gazdasági társaságot: részvénytársaságnak minősültek azok a társaságok, amelyekben egyik tag sem volt a cégnévben külön megnevezve, a társasági tőke bizonyos számú és egyenlő összegü részvényre oszlott, a részvényes tagok egyedül a részvényekért fizetett pénzeiket kockáztatták, egyéb vagyonukkal semmi esetben nem voltak kötelezettek.

Maga a részvény a részvénytársaság alapításakor vagy alaptőkéjének emelésekor kibocsátott értékpapír, amely a vállalat alaptőkéjének meghatározott részét, illetve a részvényesek jogait testesítette meg. ${ }^{104}$ Tagsági jogot megtestesítő értékpapírról egyedül a részvénytársaságoknál lehetett szó. A részvény forgalomképes volt, adásvételére gyakran került sor a tőzsdéken. ${ }^{105} \mathrm{~A}$ forgalomképesség miatt az értékpapírok öröklése is kevésbé volt problémás.

A Kt.-vel összefüggő joggyakorlatban ${ }^{106}$ felmerült kérdés a részvénykönyvbe be nem jegyzett, de egyébként már örökösöknek minősülő személyek közgyülési jogainak gyakorlására irányult: a bíróság döntése szerint a közgyülésen hozott határozatok érvényesek voltak attól, hogy a képviselök ugyan a részvénykönyvben tulajdonosként bejegyzett elhalt részvényes képviseletében szavaztak, de a per adatai szerint a hagyatéki eljárás során igazolt örökösök állították ki a képviselő számára megbízást a részvények számának megfelelő szavazati jog gyakorlására. ${ }^{107}$ Részvénykönyvet a névre szóló részvényesekröl kellett vezetni, ${ }^{108}$ amihez azt a további joghatást csatolta a Kt., hogy az üres hátirat révén történő átruházás során az azt megszerző csak akkor minősült a társaság irányában tagnak, ezáltal akkor

\footnotetext{
${ }^{103}$ Horváth 2003. 19-20.

${ }^{104}$ Horváth 2006. 521.

${ }^{105}$ Mezey (szerk.) 221-226.

${ }^{106}$ C. 291/1900. (Szende 262.)

${ }^{107}$ C. $291 / 1900$. (Szende 262.)

${ }^{108}$ Kt. 173. § (1) bek.
} 
gyakorolhatta tagsági jogait, ha a részvénykönyvbe is bejegyzésre került. ${ }^{109}$ Tehát a döntés szerint öröklés esetén a részvénykönyvbe történő bejegyzésre nem volt szükség, ami a társasági döntések meghozatalakor akár könnyebbséget is jelenthetett a részvényes örököse számára abból a szempontból, hogy nem kellett az igazgatóság bejegyzésére várni, ez azonban a részvény megszerzésének jogcímei közötti különbségtételt vonta maga után. A részvénytársaság számára megfelelöbb a helyzet, ha a részvénykönyv naprakész, és az abban megjelölt személy, illetve az általa megbízott képviselő gyakorolja a jogokat. Ha az örökös igazolni tudja ebbéli minőségét, akkor haladéktalanul érdemes volt kérelmezni a részvénykönyvi bejegyzést. Amennyiben az igazgatóság rosszhiszeműen nem tett ennek eleget, azért, hogy adott esetben az örökös ne tudjon például szavazni, akkor elképzelhető megoldás lehetett a perindítás lehetősége az igazgatóság ellen a bejegyzés érdekében. A bírói döntésben megfogalmazott tételnek csak kisegítő jellegü alkalmazását tartom célszerünek, de a probléma ma is releváns.

Több örökös vagy társtulajdonos a részvényböl eredö jogokat csak közösen gyakorolhatta, ${ }^{110}$ ugyanis a részvények felosztására csak az alapítók voltak jogosultak. ${ }^{111}$

\subsubsection{A korlátolt felelösségü társaság}

A korlátolt felelősségü társaság olyan kereskedelmi társaság volt, amely előre meghatározott törzsbetétekből álló törzstőkével alakult, amelynél a tag felelőssége a társasággal szemben törzsbetétjének szolgáltatására és a társasági szerződésben megállapított esetleges egyéb vagyoni hozzájárulásokra terjedt ki. A társaság kötelezettségeiért a tag egyébként nem felelt. ${ }^{112} \mathrm{~A}$ kft. megfelelő formának minősült a családi vállalatok számára, ,minthogy az örökösöknek tagul belépése egyszerüvé teszi a tag elhalálozásával teremtett helyzet megoldását."113

A törvény 25 . § szerint a tag halálával üzletrésze, hacsak a társasági szerződés másként nem rendelkezett, átszállt az örököseire. Erre tekintettel megállapítható, hogy

\footnotetext{
${ }^{109}$ Kt. 173. § (2) bek.: Az ily részvények átruházása üres hátirat mellett történhetik ugyan, de a birtokos, a mennyiben az alapszabályok másként nem intézkednek, a társaság irányában igazoltnak csak akkor tekintetik, ha az átruházás a részvény felmutatása mellett a társasági részvénykönyvbe bevezettetett.

${ }^{110}$ C. 1084/85. (Ü. L. 89. 12. sz.), 1080/85. (J. 86. 118. 1.) = Nagy F. 340.

${ }^{111}$ Nagy F. 339-340.

112 Kfttc. 1. § (1) bek.

${ }^{113}$ Kuncz 1937b. 91.
} 
a törvény alapvetően a felekre bízta valamely tag halála folytán bekövetkező változások feletti kontrollt, ennek hiányában a hatályos jogszabályban továbbélő ipso iure jellegü öröklés jelent meg az üzletrészek esetében.

Az eltérő rendelkezésre példa az üzletrész átszállásának kizárása, ahogy az később megvalósulhatott a Gt. hatálya alatt is, amire azonban a Ptk. szerint már nincs lehetőség, csak a meghatározott személy által történő magához váltás maradt. ${ }^{114}$

Ha az átszállást kizárta a társasági szerződés, a társaságnak az üzletrészt a társasági szerződés más rendelkezése hiányában az érték megtérítése mellett a törzstőke-leszállítás szabályainak megfelelő alkalmazásával be kellett vonnia. ${ }^{115}$ „Az üzletrészbevonás eseteit a társasági szerződés elvileg szabadon állapíthatja meg. Így kimondhatja az örökös üzletrészének bevonását arra az esetre, ha az örökös az elhalálozott tag mellékszolgáltatásait nem tudja, vagy nem akarja teljesíteni." 116 Tehát még a bevonás sem volt kötelező, a jogszabály ismeretében teljes szabadságot kaptak a tagok az üzletrészeik haláluk utáni sorsának meghatározását illetően.

Az üzletrész felosztásának egyik esete a több örökös általi örökléshez kötődött az ún. részleges átruházás mellett: ${ }^{117}$ a felosztáshoz a társaság beleegyezése és a törzsbetétek nagyságára vonatkozó szabályok betartása, azaz minimum ezer pengős törzsbetét, volt szükséges. Több örökös esetén, ha nem osztották fel az üzletrészt, a 27. § szerinti közös tulajdonú üzletrész jött létre, amelynek tartalma hatályos szabályozásunkban élt tovább.

\subsubsection{A csendestársaság}

Magyarországon először az 1840:18. tc. szabályozta ezt a kereskedelmi társasági formát. A törvény megfogalmazása szerint a közkereseti társaságok oly tagokat is felvehettek, akik csak veszélyre (Einlage auf Gefahr) tettek bizonyos befizetést, erre a törvényes mértékü kamatnál nagyobb kamatot köthettek ki, de a társaság ügyeiben egyébként nem vettek részt, $\mathrm{s}$ a befizetett sommán felül, egyéb vagyonukkal a társaság tartozásaiért nem feleltek, az ilyen tagokat kültagoknak (commenditairs, stille Gesellschafter) nevezték. A kültagoknak aposztrofált csendestársakat a francia, illetve a német megfelelőkkel kívánja magyarázni, amely

\footnotetext{
${ }^{114}$ Ptk. 3:170. $\S(2)$ bek.

${ }^{115}$ Kfttc. 25. § (2) bek.

${ }^{116}$ B. T. 14.234/1933.; Kuncz 1937b. 399.

${ }^{117}$ Kfttc. 26. § (1) bek.
} 
magyar megnevezés végül a betéti társaság egyik tagjának elnevezéseként honosodott meg, és használjuk ugyanilyen minőségben a hatályos társasági jogi szabályozás alapján. A francia kifejezés valóban a betéti társaság kültagját takarja, viszont a stille Gesellschafter a csendestársra utal ugyanúgy, ahogy a kamatkikötés lehetősége, valamint az, hogy a társaság ügyeiben egyébként ez a személy nem vett részt. Ez a törvény nem tartalmazott az öröklésre vonatkozóan különös szabályokat e társasági típust illetően, éppen ezért a közkereseti társaságnál írtak erre a típusra is ugyanúgy vonatkoznak, figyelemmel arra, hogy a közkereseti társaság egyik altípusaként került szabályozásra.

A Kt. ezt a társasági formát nem ismerte. A következő szabályozást csak 90 évvel később találhatjuk meg, az 1930. évi V. törvénycikkben, egy törvényben a korlátolt felelősségű társaságokkal. Csendestársaság keletkezett, ha valaki (a csendestárs) anélkül, hogy kifelé tagul jelentkezett volna, másnak vállalatában vagyoni betéttel úgy vett részt, hogy azt a vállalat tulajdonosának rendelkezésére kellett adni. A vállalat ügyletei egyedül a vállalat tulajdonosát jogosították és kötelezték; azokból a csendestársra harmadik személyekkel szemben sem jogok, sem kötelezettségek nem származtak. ${ }^{118,119}$

A 119. § szerint a csendestársaság feloszlott, ha a vállalat tulajdonosa (azaz aki nevével megjelent a vagyoni forgalomban) meghalt, kivéve, ha a szerződés akként szólt, hogy a társasviszonyt az örökösökkel tovább kellett folytatni. Így bekövetkezhetett a jogutódlás, amire, miután az örökhagyó a saját cége alatt végezte ezt a tevékenységet, az erre irányadó szabályokat kellett alkalmazni. A társasviszony megszűnése esetén, tehát például a tulajdonos halálával, a csendestárs nem követelhetett felszámolást vagy végelszámolást, hanem csupán a Kt. 105. és 106. §-ainak megfelelő végkiegyenlítést kapott úgy, mintha a társaságból kilépett volna. ${ }^{120}$ A tagok közötti különbségtétel nem csupán a fogalomban, illetve a kereskedelmi társaság alapelemeként jelent meg, hanem a haláluk esetére irányadó rendelkezésekben is, ugyanis a csendestárs halála vagy cselekvőképességének elvesztése a társasviszonyt kétség esetén nem szüntette meg, ellentétes volt a két tagi pozícióban lévő személy halála utáni helyzet rendezésének föszabálya.

\footnotetext{
${ }^{118}$ Kfttc. 115. § (1)-(2) bek.

${ }^{119}$ A csendestársaságra lásd még Mohai 2016a. 114.

${ }^{120}$ Kfttc. $120 . \S$
} 
Magyarországon a hatályos szabályok alapján nem lehet csendestársaságot alapítani, ellenben az osztrák szabályozás ezt megengedi, ahol a betéti társasághoz hasonlóan szintén különbséget tesznek az egyes tagok halálának jogkövetkezményei vonatkozásában a tagi minőségek szempontjából: ha a csendestárs hal meg, akkor az nem vezet a társaság megszünéséhez, ${ }^{121}$ míg a ténylegesen üzletet vivő személy halálával a csendestársaság is megszünik. ${ }^{122}$

\section{7. Összefoglalás}

A társasági jog jogtörténeti vizsgálata alapján megállapítható, hogy az öröklési joggal fennálló kapcsolata nem csupán a modern magyar jogban, hanem már azt megelőzően is felfedezhető. Már a kereskedelmi társaságok első magyar kodifikálásakor, 1840-ben is felismerték, hogy nem csupán a felek akaratából, a felektől független külső tényezők vagy a társaság veszteséges müködése alapján megszünik egy alapvetően a tagokra, illetve a tagok személyes együttmüködésére alapuló társaság, hanem annak egy tagjának a halála miatt is. Ennek szabályozására megfelelő módot biztosítottak: alapvetően a felek megállapodására bízták a helyzet rendezését, míg a megállapodás hiánya esetére a törvénybeli jogkövetkezmények érvényesültek. A tőkeegyesítő jellegü társaságoknál ilyenre nem találunk példát.

A Kt. már sokkal részletesebben szabályozta a kereskedelmi társaságokat, e körben már az öröklési jogot is érintette. A szabályozás indokoltságát bizonyítja a bírói gyakorlatban felmerült jogesetek nagy száma. Abból kell kiindulni, hogy adott kereskedelmi társaság erősen személyegyesítő jelleget viselt-e magán, ahogy az a közkereseti és a betéti társaságnál is, vagy a tőkeegyesítő jegyek voltak erősebbek, amint az a részvénytársaságnál és a korlátolt felelősségű társaságnál már akkor is megfigyelhető volt. A személyegyesítő jelleg domináns volt, ami szerint a mai főszabállyal ellentétben, a társaság megszűnt valamely tag halálával, kivétel, ha a társasági szerződésben már előre ettől eltérően rendelkeztek, míg a tőkeegyesítő társaságoknál a tag halála nem jelentette a társaság megszünését, legfeljebb a részesedés örökösre való átszállásáról rendelkezhettek másképp.

\footnotetext{
${ }^{121}$ UGB 184. § (2) bek.

${ }^{122}$ Welser 452.
} 


\section{3. Öröklési jogi alapvetések}

A társasági jog és az öröklési jog kapcsolatának vizsgálata körében elengedhetetlen azon öröklési jogi szabályok ismerete, amelyek szerepet játszanak a gazdasági társaságokban fennálló részesedések öröklésénél is.

$\mathrm{Az}$ öröklési jogi értelemben vett halállal egyenlő joghatása (az emberi jogképesség megszűnése szempontjából) van a holttá nyilvánításnak, ${ }^{123}$ és deklaratív jelleggel bír a halál tényének bírói megállapítása. ${ }^{124}$

\subsection{Az addicionális és az ipso iure öröklési rendszer}

$\mathrm{Az}$ addicionális rendszerek közös vonása, hogy a hagyaték megszerzéséhez szükséges egy elfogadó nyilatkozat, amelynek megtételéig a hagyaték önálló vagyontömegnek minősül, gondozására pedig külön gondnokot rendelnek. Az ipso iure rendszer alapján ezzel szemben az örökös az örökhagyó halálakor minden külön jognyilatkozat nélkül szerzi meg az örökséget. A magyar öröklési jog - a modern jogrendszerek többségéhez hasonlóan - nem kíván meg az örökség megszerzésére irányuló elfogadó jognyilatkozatot, ${ }^{125}$ ezért az ipso iure rendszerhez tartozik, ezt maga a Ptk. is deklarálja. ${ }^{126} \mathrm{Az}$ ipso iure öröklési rendszerből következően a közjegyző által meghozott hagyatékátadó végzés nem konstitutív (jogkeletkeztető) hatályú, hanem pusztán az öröklés közhitelű tanúsítására szolgál. ${ }^{127}$ E rendszer automatizmusa miatt mondható el az, hogy az öröklési jogi jogviszonyok esetén vagyonátszállásról beszélhetünk, és nem vagyonátruházásról. ${ }^{128}$

A két rendszer között hasonlóság állapítható meg az örökség visszautasítása vonatkozásában, de ez az egyezés csupán látszólagos: mindkét rendszernél van egy időszak, ami alatt az örökös személye még nem bizonyos, de az addicionális rendszerekben a hagyaték megnyílása és elfogadása között a hagyaték mindig nyugvó hagyaték. Ehhez képest az ipso iure rendszerekben, ha az örökös visszautasítja az

\footnotetext{
${ }^{123}$ Ptk. 2:5-2:7. §, 1/1960. IM rend. 1-19. §, 21-22. §, 2018. január 1-jétől a 2017. évi CXVIII. törvény 311. §-ai tartalmazzák az eljárás rendelkezéseit. Bíró 171-176., Havasi 52-63.

${ }^{124}$ 1/1960. IM rend. 20-22. §, 2017. évi CXVIII. törvény 12. §; Bíró 171., Havasi 52.

${ }^{125}$ Vékás 2014b. 13-14.

${ }^{126}$ Ptk. 7:87. § (2) bek., Vékás - Weiss 2373.

${ }^{127}$ Fábián 2014. 7-8., Vékás - Weiss 2373., Orosz 2014c. 215., Anka 2014b. 720.

${ }^{128}$ Sápi 2016a. 9., Vö. Anka 2013. 157.
} 
örökséget, ugyan a hagyaték megnyílásakor örökös volt, de az így kieső örökös helyébe erre az időpontra visszamenőleges hatállyal lép az új örökös. Azaz létezhet olyan időszak, amikor bizonytalan, ki szerezte meg a hagyatékot örökösként, de nincs olyan, amikor a hagyatéknak egyáltalán ne lenne örököse. ${ }^{129}$ Ennek a gondolatnak - ha már nem csupán a visszautasítás dimenziójában gondolkodunk - nagy jelentősége van a társasági jogban is az öröklést illetően. Addicionális rendszerekben az örökösnek öröklési igénye keletkezik, amit érvényesíthet, és mint igény, elévülhet.

Az ipso iure rendszert szemléletesen jellemzi az alábbi gondolat: „a halállal egyidejüleg beáll a jogutódlás, örököl az is, aki nem tud róla, még tudat, a tény ismerete sem kell hozzá, a halál elrendezi a statikus vagyoni viszonyokat, felosztja a hagyatékot és igényeket nyit meg."130 Ennek a gondolatnak némileg ellentmond a társasági jog akkor, amikor valamely tag meghal: bizonyos társasági formáknál nem válik automatikusan taggá az örökös, egyfajta elfogadó nyilatkozat (pontosabban az életben maradt tagokkal való megegyezés) szükséges, hasonlóan az addicionális öröklési rendszerekhez, azt azonban le kell szögezni, hogy a kettő jognyilatkozat eltérö alapokon nyugszik. Ugyanis a társaságoknál ilyen esetekben egy teljesen sajátos folyamat játszódik le: legfőbb szervi határozattal módosítani kell a társasági szerződést, valamint a belépni kívánó örökösnek nyilatkoznia kell, hogy a társasági szerződést magára nézve kötelezőnek ismeri-e el.

Tehát a Ptk. - eltérően más európai államok szabályozásától - nem ismeri se az uratlan, se a nyugvó hagyaték jogintézményét, mindezek azt jelentik, hogy mindenkinek van örököse, hiszen végső esetben, ha más személy nem, akkor az állam, mint szükségképpeni örökös fog örökölni, ${ }^{131}$ valamint azt, hogy az örökhagyó halálával az örökös automatikusan megszerzi a hagyatékból rá eső részt, nem kell külön elfogadó nyilatkozat. Az öröklési jogi szabályok biztosítják a nyugvó és az uratlan hagyaték által okozott bizonytalan helyzetek elkerülését, de ahogy az kifejtésre is kerül, jelentősebb idő is eltelhet az örökhagyó halála és a hagyaték átadása között, azaz a jogutód személyének megállapítása, annak közhiteles tanúsítása elhúzódhat, ${ }^{132}$ ami a társasági jog vonatkozásában a bírói gyakorlatban jogértelmezési gondot okozott.

$\mathrm{Az}$ addicionális rendszer egyik példája az összehasonlítás alapjául szolgáló osztrák jog, ahol öröklés esetén három stádium különböztethető meg: az első időszak az

\footnotetext{
129 Anka 2014b. 733.

${ }^{130}$ Csehi 2013. 25.

131 Sápi 2016a. 9.

${ }^{132}$ Fabó 2014c. 400.
} 
örökhagyó halála, ebben az időpontban azok hívhatók fel öröklésre érvényesen, akik élnek, ezáltal öröklési képességgel rendelkeznek. Ezek a felhívott örökösök sem léphetnek birtokba önhatalmúlag, ellentétben a magyar joggal: az öröklés visszautasításának jogáról való lemondásként értelmezik azt, ha ráutaló magatartással sajátjaként rendelkezik a hagyaték tárgyáról; a megszerzést bírói eljárásnak kell megelöznie, amely során a leendő örökösnek el kell döntenie, hogy az örökséget elfogadja-e vagy lemond róla; ha elfogadja, és bizonyítja az örökléshez való jogát, a bíróság átadja neki a hagyaték őt megillető részét. ${ }^{133} \mathrm{Az}$ öröklésre történő felhívás három jogalapon történhet: a törvényi sorrend szerint öröklési szerződésen, végrendeleten, illetve törvényen alapuló öröklés lehet, amelyek egymás mellett is érvényesülhetnek, ${ }^{134}$ előfordulási gyakoriságuk éppen a törvényi sorrenddel ellentétes. ${ }^{135}$ Mindaddig, amíg az örökös nem szerzi meg a hagyatékot, a hagyaték jogi személynek minősül az örökhagyó halálától: jogok és kötelezettségek alanya lehet, az örökhagyó vagyontárgyainak tulajdonosa, perképes, azaz perelhet és perelhető. ${ }^{136}$ Erre a speciális jogi helyzetre azért van szükség, mert nem lehet pontosan tudni, kik válnak végül örökössé. A nagyfokú hasonlóságok és elméleti megfontolások ellenére ez a szituáció nem ugyanaz, mint ami a magyar jogban is jelen van, ami szerint az örökhagyó halála és a hagyaték hagyatékátadó végzéssel történő közhitelü átadása (illetve öröklési per esetén annak jogerős eldöntése) között szintén jelentősebb időszak telhet el. A két szabályrendszer (és konkrétabban az osztrák és a magyar öröklési jog) egyik közös vonása, a bizonytalansági faktor ugyanúgy megvan: kérdéses, hogy aki örökös lehet, ténylegesen azzá fog-e válni. Például az ipso iure rendszerben visszautasítja-e az örökséget, vagy más módon az örökhagyó halála után kiesik-e az öröklésböl, az addicionális rendszerben pedig lesz-e olyan személy, aki elfogadja az örökséget. Mindezek alapján tehát a magyar öröklési jog alapján örökössé váló személyek ipso iure, az örökhagyó halála folytán örökösök lesznek, míg a leendő örökösöknek az osztrák jog szerint külön jelentkezniük kell az öröklésre.

$\mathrm{Az}$ Európai Unió Öröklési Rendelete szerint a nyugvó hagyaték esetét, pontosabban annak lehetőségét az egyes jogok eltérően szabályozzák, bizonyos államokban az állam örökösként a vagyontárgyak fellelhetőségétől függetlenül igényt támaszthat a nyugvó hagyatékra, míg más jogokban az állam csak a területén fellelhető

\footnotetext{
${ }^{133}$ Welser 445.

${ }^{134}$ ABGB 533-534. §

135 Welser 453-454.

${ }^{136}$ Welser 566.
} 
vagyontárgyakhoz juthat hozzá. A jogszabály célkitűzése olyan szabály alkotása, amely meghatározza, hogy az öröklésre irányadó jog alkalmazása nem zárhatja ki azt, hogy egy tagállam saját joga szerint a saját területén fellelhető vagyontárgyakhoz hozzájuthasson. Azonban annak biztosítása érdekében, hogy ez a szabály a hagyatéki hitelezőket ne érintse hátrányosan, ki kellett azt egészíteni egy olyan rendelkezéssel, amelynek értelmében a hagyatéki hitelezők a hagyatéki vagyontárgyak összességére vonatkozó követelésüknek érvényt szerezhetnek, azok fellelhetőségétől függetlenül. ${ }^{137}$ Mindezekre tekintettel, amennyiben az öröklésre a Rendelet értelmében alkalmazandó jog szerint egyik vagyontárgy tekintetében sincs sem végintézkedésben nevezett örökös vagy hagyományos, sem törvényes öröklésre jogosult természetes személy, az így meghatározott jog alkalmazása nem zárja ki azt, hogy valamely tagállam vagy az ezen tagállam által e célra kijelölt intézmény a saját joga alapján megszerezze a területén található hagyatéki vagyontárgyak tulajdonjogát, feltéve, hogy a hitelezők jogosultak arra, hogy követeléseikre a hagyatéki vagyontárgyak összességéből kielégítést keressenek. ${ }^{138}$ Azaz ezzel ellentétes jogszabályt egyik uniós tagállam joga sem tartalmazhat.

A cikk címe a magyar szövegváltozata szerint „Nyugvó hagyaték”, ehhez képest annak tartalma jogunkban az állam szükségképpeni törvényes örökösi pozíciója miatt ismeretlen uratlan hagyatékra utal. Ezt a véleményt erősíti meg a Rendelet német nyelvü hivatalos változata is, amelyben a cikk címe az Erbenloser Nachlass elnevezést viseli.

A cikk azt a kérdéskört szabályozza, mely állam szerzi meg a hagyatékot: amelyikben a hagyaték fellelhető, vagy amelyik a Rendelet alapján megállapított alkalmazandó jog szerint örökössé válhat, amennyiben ez ilyen eseteket ekképp szabályozza. A problémát az okozza, hogyha valamelyik állam fenntartja magának a jogot, hogy a területén található uratlan vagyon felett tulajdonjogot szerez, holott az egy másik állam joga alapján nem uratlan, hanem ez az állam öröklés útján megszerzi. ${ }^{139} \mathrm{~A}$ jogszabály szövege alapján akkor nincs örökös, ha sem törvényes örökös, sem végintézkedés útján nincs természetes vagy jogi személy, aki örökös lehet. ${ }^{140} \mathrm{~A}$ hivatkozott kommentár a hagyományost is idesorolja, tehát van örökös, ha csak hagyományos van; a hagyományos azonban a magyar jog alapján nem örökös, tehát elvileg, ha az állam nem lenne szükségképpeni törvényes örökös, úgy a magyar jog

\footnotetext{
137 (56) preambulum-bekezdés

138 33. cikk

${ }^{139}$ Lagarde 182.

${ }^{140}$ Lagarde 183.
} 
alapján lehetne uratlan hagyaték. Ennek ellenkezője miatt, ha a magyar jogot kell alkalmazni a Rendelet alapján, nem lesz ilyen hagyaték, ekkor viszont meg kell vizsgálni, hogy a hagyaték fekvése szerinti jog mit rendel, van-e konfliktus a két jogrend között abban a vonatkozásban, hogy a hagyaték fekvési helye szerinti jog magának vindikálja-e a hagyatékot, vagy sem.

\subsection{Az öröklési jog alapfogalmai}

Öröklésről tágabb értelemben akkor beszélünk, amikor a meghalt személy vagyona vagy annak valamely része a halál után más személyre száll át, míg szükebb értelemben csak a meghalt ember vagyonában bekövetkező egyetemes jogutódlást jelenti. ${ }^{141}$ A kettő közötti különbség az, hogy valódi öröklésről csak a szűkebb értelmezés esetén van szó, míg a tágabb kategóriába vonható a kötelesrész, a hagyomány, valamint a meghagyás. A jogintézmény lehetőséget biztosít arra, hogy az örökölt vagyon által a generációk közötti folyamatosságot teremtse meg, ami társadalmi és kulturális célokat is szolgál. ${ }^{142}$ Az öröklés fogalma az emberhez kapcsolódik, jogi személyek esetében a bővebb kategóriát jelentő (az öröklést is magában foglaló) jogutódlásról lehet szó, melynek szabályait az egyes jogalanyok jogi helyzetét meghatározó külön rendelkezések tartalmazzák. ${ }^{143}$ Az öröklés fontosságát mutatja az, hogy az Alaptörvény XIII. cikk (1) bekezdése szerint Magyarország elismeri az örökléshez való jogot a tulajdonhoz való joggal együtt, mert az öröklés valójában az örökhagyó felől nézve a tulajdon tartalmát tevő rendelkezési jog kiterjesztése. ${ }^{144}$

A Ptk. 7:1. §-ban megfogalmazott rendelkezés a magyar öröklési jog alapvető tétele: az ember halálával hagyatéka, mint egész száll az örökösre. E § két jogtételt foglal magában: egyrészről azt, hogy minden embernek szükségképpen van egyetemes jogutódja, azaz örököse, másrészről jelenti azt is, hogy csak az minősül örökösnek, akire a hagyaték vagy annak hányada, mint egész száll át. ${ }^{145} \mathrm{Az}$ öröklés a tulajdonjog átszállásának egyik módja, ${ }^{146}$ jogcíme lehet törvényes, illetve végintézkedésen alapuló öröklés, a társasági jogi részesedések öröklése mindkét jogcímen megvalósulhat. ${ }^{147}$

\footnotetext{
${ }^{141}$ Világhy 5., Sápi 2016a. 8.

${ }^{142}$ Kreiczer-Levy 106.

${ }^{143}$ Fábián 2014. 7.

${ }^{144}$ Fábián 2015. 11.

145 Orosz 2014c. 216.

${ }^{146}$ BDT 2013. 2392. I.

${ }^{147}$ Utóbbira lásd pl. K-H-KJ-2015-787.
} 
A magyar és az osztrák jog szerint csak az számít örökösnek, aki a teljes hagyatékot vagy annak egy meghatározott hányadát, mint egészet szerzi meg, szemben a hagyománnyal vagy a kötelesrésszel, amelyek kötelmi igények, és azokkal a kötelezettségek nem szállnak át. ${ }^{148}$

A hagyaték ${ }^{149}$ az örökhagyóról halála esetén jogutódaira átszálló egész - aktív és passzív - vagyon, amely az örökhagyó vagyontárgyainak, valamint polgári jogi jellegü vagyoni jogainak és kötelezettségeinek összessége, amelyekben helye lehet halál esetére vonatkozó alanyváltozásnak. ${ }^{150}$ A vagyon - pontosabban a vagyonhoz tartozó vagyontárgyak - fogalma szélesebb, mint a dolgokon fennálló tulajdonjog, ahhoz a vagyoni értékü materiális és immateriális jogosultságok is hozzátartoznak. ${ }^{151} \mathrm{~A}$ hagyaték egészének öröklése a jogok és kötelezettségek együttes öröklését jelenti, az „egész” szó tehát arra utal, hogy az aktívák mellett a passzívákat is megszerzi az örökös. Ettől eltérően például a halál esetére szóló ajándékozás esetén singularis jogutódlásról van szó, ${ }^{152}$ valamint öröklési szerződés esetén a szerződéses örökös tekintettel arra, hogy ellenszolgáltatást (tartás, életjáradék) nyújtott az örökhagyónak nem tartozik helytállással a hagyatéki tartozásokért. Az értekezés kontextusába helyezve a hagyatékba tartoznak a társasági részesedések is. ${ }^{153}$

Az örökhagyó az elhunyt személy, akinek vagyonában a halála miatt egyetemes jogutódlás következik be. ${ }^{154}$ Társasági jogi kontextusba helyezve az a személy is örökhagyó, aki a halálakor egy gazdasági társaság tagja volt, azaz akinek a vagyonában a társasági részesedés megtalálható.

Az örökös az örökhagyó egyetemes jogutódja, ${ }^{155}$ az örökhagyó vagyoni jellegű jogainak és kötelezettségeinek vagy azok meghatározott hányadának új alanya. Kivételesen örökösnek minősül az örökhagyó egyes meghatározott vagyontárgyainak megszerzője is, ${ }^{156} \mathrm{pl}$. végrendeleti juttatás alapján a hagyaték összértékének jelentős részét kitevő ingatlan, részvények, stb. új tulajdonosa. Az örökös szerzi meg a társasági vagyoni részesedést, ezzel - a társaság formájától függően - tagsági jogviszonya keletkezik.

\footnotetext{
${ }^{148}$ Welser 442.

149 A fogalmára lásd például BDT 2011. 2385., FIT-H-PJ-2015-442., GYIT-H-PJ-2014-99.

${ }^{150}$ Vékás 2013. 17., Világhy 11-12., Fabó 2014c. 399.

${ }^{151}$ BDT 2007. 1581., vö. K-H-PJ-2012-499.

${ }^{152}$ Vékás - Weiss 2374.

${ }^{153}$ Csehi 2014. 23.

${ }^{154}$ Vékás 2014b. 16.

${ }^{155}$ FIT-H-PJ-2011-1289.

${ }^{156}$ Vö. Ptk. 7:25. § (3) bek., Vékás 2014b. 17-18., Világhy 11-12.
} 
„A különös (singularis) jogutódlás esetén csupán az egyes jogi helyzetek alanyainak kicseréléséről van szó, míg az egyetemes (universalis) jogutódlásnál pedig valamely egész vagyon alanyának kicserélődése áll be." ${ }^{157}$ A társasági jog és az öröklési jog kapcsolatát érintve gyakoribb az universalis jogutódlás, de elképzelhető különös jogutódlás is, azaz halál esetére szóló ajándékozás, ${ }^{158}$ hagyomány, ${ }^{159}$ valamint meghagyás ${ }^{160}$ tárgya lehet a négy gazdasági társasági forma valamelyikében fellelhető társasági részesedés.

Álörökös az, aki a hagyatékot vagy annak egy részét - öröklés jogcímére hivatkozással - a birtokában tartja vagy birtokba veszi anélkül, hogy erre érvényes öröklési jogcíme lenne, ${ }^{161}$ a hagyatékhoz tartozó jogoknak és követeléseknek nem jogosultja. ${ }^{162} \mathrm{Ha}$ a hagyaték nem a hagyatéki eljárás vagy az öröklési per jogerős befejezésével örökösként deklarált személynél van, akkor annak kiadását ez a személy a jogalap nélküli birtoklás szabályai szerint ${ }^{163}$ követelheti a birtokostól. ${ }^{164} \mathrm{Az}$ álöröklésnek szoros kapcsolata van az öröklési igénnyel, mint jogintézménnyel, ami által az elismert örökösök tulajdoni igénnyel léphetnek fel. ${ }^{165} \mathrm{Az}$ álörökös tulajdonszerzési jogcíme csakis elbirtoklás lehet, akkor is, ha jóhiszemü jogalap nélküli birtokosként ö maga is örökösnek véli magát. Álörökös az a személy, aki az előbbieknek megfelelően az örökhagyó tag tagsági jogviszonya alapján belép a közkereseti, illetve betéti társaságba, akit a kérelmének megfelelően az ügyvezető bejegyez a korlátolt felelősségü társaság tagjegyzékébe, valamint az is, aki a nyomdai úton előállított, illetve dematerializált részvényt megszerzi. Az álörökös jogalap nélkül gazdagodik, a valódi örökös és az álörökös között ez a tény hozza létre azt a jogviszonyt, amelyből eredően az örökös a Ptk. 6:579. § alapján a vagyoni előny visszatérítését követelheti. ${ }^{166} \mathrm{Az}$ álörökös végrendelet esetén kerülhet szóba, ekkor az álörökös a törvényes örökös, a valódi örökös pedig a végrendeleti örökös a végrendelet érvényessége esetén. ${ }^{167} \mathrm{Az}$ álörökös által megszerzett társasági részesedés értékének növekedésére vonatkozóan a jogalap nélküli birtoklás szabályai lesznek irányadóak:

\footnotetext{
${ }^{157}$ Tarr 274.

${ }^{158}$ Ptk. 7:53. §

${ }^{159}$ Ptk. 7:31-7:32. §, 7:34. §, 7:36. §

${ }^{160}$ Ptk. 7:33-7:34. §, 7:36. §

${ }^{161}$ Orosz 2014c. 303-304., Vékás - Weiss 2494.

${ }^{162}$ Sápi 2016b. 79.

${ }^{163}$ Ptk. 5:9-5:12. §

${ }^{164}$ Fabó 400.

${ }^{165}$ EBH 2004. 1024., Vékás - Weiss 2377.

${ }_{166}$ LB-H-PJ-2008-1658.

${ }^{167}$ BDT 2013. 2932.
} 
eszerint mivel ingyenesen jutott a birtokhoz, jó- vagy rosszhiszemüségétől függetlenül köteles kiadni a jogosultnak a dolog meglévő hasznait, de pl. rosszhiszemüség esetén valamennyi létező haszon (elfogyasztott vagy beszedni elmulasztott) ellenértékével tartozik. $^{168}$

Hagyományt végintézkedésben lehet rendelni, amely singularis jogutódlásnak minősül. Dologi hagyomány a hagyatékban meglévő valamely vagyontárgynak meghatározott személy részére juttatása, ha az ilyen részesedés nem minősül öröklésnek. ${ }^{169}$ Kötelmi hagyomány ehhez képest az, ha az örökhagyó az örökösét arra kötelezi, hogy a hagyományosnak vagyoni szolgáltatást teljesítsen. ${ }^{170}$ Hagyományt az örökös javára is lehet rendelni (előhagyomány), ezt az örökrészen felül kapja, és a hagyományost is terhelheti hagyomány juttatása (alhagyomány). ${ }^{171}$ Amennyiben kétség támad abban a vonatkozásban, kit terhel a hagyomány, akkor úgy kell tekinteni, hogy az az örököst terheli. ${ }^{172}$ Hagyomány lehet a társaságbeli vagyoni hozzájárulás is, de csak akkor, amennyiben az nem teszi ki az egész hagyaték értékének jelentős részét. Ha kiteszi, akkor örökösnek kell tekinteni az ilyen juttatásban részesített személyt is, ha az örökhagyó feltehető akarata szerint a részesítettnek a hagyatéki terhek viselésében is osztoznia kell. ${ }^{173}$

Az utóöröklés azt jelenti, hogy az örökhagyó akképp nevez meg több személyt örökösül, hogy egyikük (előörökös) csak bizonyos időpont vagy esemény beálltáig (általában ennek a személynek a haláláig) legyen örököse, ezután a másik személy, az utóörökös örököl. Olyan speciális jogintézmény, amellyel az örökhagyó elviekben több generációra vonatkozóan előre meg tudja határozni a hagyatékából való részesedést; ${ }^{174}$ éppen erre tekintettel a Ptk. is csak szük körben engedi meg. ${ }^{175}$

\footnotetext{
${ }^{168}$ Benke [87]

${ }^{169}$ Ptk. 7:31. § (1) bek.

${ }^{170}$ Ptk. 7:31. § (2) bek.

${ }^{171}$ Orosz 2014a. 65-66.

${ }^{172}$ Ptk. 7:31. § (3) bek.

${ }^{173}$ Vö. Ptk. 7:25. § (3) bek., Vékás 2014b. 18-19.

174 Orosz 2014a. 63.

${ }^{175}$ Lásd Ptk. 7:28. § (3)-(4) bek., Vékás 2014b. 52-55.
} 


\subsection{Az öröklés előfeltételei}

Az öröklés körében a jogtudomány a törvényi szabályozás, illetve az elméleti vívmányok alapján olyan előfeltétel-rendszert alakított ki, amelyek közül mindegyiknek a teljesülése szükséges az örökléshez: ${ }^{176}$

a) Az öröklés halál esetére bekövetkező jogutódlás, azaz az örökhagyónak meg kell halnia. A halál időpontjában nyílik meg az öröklés, ez a momentum határozza meg az örökölhető vagyon körét, valamint az örökös személyét, aki ekkor tudja megszerezni a ráeső vagyonhányadot, továbbá a kötelesrész, ${ }^{177}$ hagyomány, meghagyás, halál esetére szóló ajándékozás keletkezésére is irányadó. ${ }^{178} \mathrm{~A}$ halál $^{179}$ tényének és idejének megállapítása orvosi szakkérdés, amit halottvizsgálattal határoznak meg. ${ }^{180}$ Az örökhagyó halála nélkül nem lehet örökölni, addig legfeljebb öröklésre vonatkozó remény van. ${ }^{181}$

b) Éppen ezért, az a) ponthoz kapcsolódóan az örökösnek túl kell élnie az örökhagyót, ennek inverze a Ptk.-ban kiesési okként található meg. ${ }^{182}$ Önmagában abból a tényből is következik, hogy az elhunyt embernek nincs jogképessége, ${ }^{183}$ az örökhagyó halálának időpontja dönti el, ki válhat örökössé, ekkor szállhatnak át meghatározott jogok és kötelezettségek. ${ }^{184}$ A régi Ptk.-tól eltérően a Ptk. már tartalmaz a közös veszélyben elhunytak vonatkozásában vélelmet, miszerint a közös balesetben vagy más közös veszélyhelyzetben elhunyt személyek a halál beálltának idejétől függetlenül kiesettnek tekintendők. ${ }^{185}$

c) Az öröklési képesség egybeesik a polgári jogi jogképességgel, ami „valójában az általános polgári jogi jogképesség öröklési jogra vetített vonatkozása; valamely személy képességét jelenti arra, hogy a hagyatékra nézve öröklési jogcímen jogokat szerezhessen, és az örökléssel kapcsolatos kötelezettségek

\footnotetext{
${ }^{176}$ Bővebben lásd: Vékás 2014b. 21-33., Világhy 14-23.

177 A kötelesrész megítéléséről lásd Fiedler 444-449.

${ }^{178}$ Vö. Fabó 2014c. 400.

179 Az Eütv. 216. §-a tartalmazza az agyhalál, a klinikai halál, a halál, valamint a perinatális halál fogalmát.

${ }^{180}$ Lásd Eütv. 217. § (1) bek., Szikora 2014. 109., Lenkovics 67., Kőrös - Makai 90.

${ }^{181}$ ABGB 879. § (2) bek., Welser 444-445.

${ }^{182}$ Ptk. 7:4. $\S(1)$ bek.

183 Ptk. 2:4. $\$$

${ }^{184}$ Szikora 2014. 109

${ }^{185}$ Ptk. 7:4. § (1) bek.
} 
terhelhessék." ${ }^{186}$ Minden ember jogképes, ${ }^{187}$ továbbá jogképességgel bírnak a jogi személyek ${ }^{188}$ is, így elviekben bárki és bármi örökölhet. ${ }^{189}$

d) A szerzőképesség szükebb tartalommal bír, mint az öröklési képesség, nem mást jelent, mint azt, hogy az öröklésre elvben képes személy a konkrét esetben valóban meg tudja-e szerezni a hagyaték ráeső részét. ${ }^{190}$ A magyar jogban szerzőképességi korlátozás csupán a házastársakra vonatkozóan van. ${ }^{191}$ Egyet lehet érteni azzal a jogirodalmi állásponttal, ${ }^{192}$ miszerint helyesebb lenne az öröklési képességet a szerzőképesség öröklési jogi megjelenéseként értelmezni, mintsem az absztrakt jogképességgel azonosítani, mivel e felfogás szerint a jogképesség kategóriáját valamennyi polgári jogi jogintézmény (pl. tulajdon, szerződés) jogai és kötelezettségei tekintetében felállíthatnánk ilyen fogalmi párokat feleslegesen megsokszorozva a jogképesség elvont kategóriáját. $\mathrm{Az}$ osztrák irodalom szerint az öröklési képesség az öröklési jogi szerzőképesség. ${ }^{193}$ Ezzel nem tesz különbséget a két fogalom között, amely különbségtétel egyébként öröklési jogi szempontból nem bír jelentős relevanciával, miután minden jogalany rendelkezik ezzel a képességgel. Ehhez képest létezik az abszolút, illetve relatív öröklésre való képtelenség kategóriája, előbbibe tartoztak korábban a saját egyházuk szabályai szerint öröklésre képtelen személyek, valamint azon külföldi országok állampolgárai, amely állam szabályai szerint az osztrákok nem örökölhettek, ezáltal kedvezőtlenebb helyzetben vannak, mint az adott állam állampolgárai, ez tulajdonképpen nemzetközi jogi értelemben vett retorziónak ${ }^{194}$ minősül. A relatív okok közé tartozik az érdemtelenség: az Osztrák Legfelsőbb Bíróság kimondta, hogy az

\footnotetext{
${ }^{186}$ Fábián 2014. 10.

${ }^{187}$ Ptk. 2:1. § (1) bek.

${ }^{188}$ Ptk. 3:1. § (1) bek. Ugyanezen $\S(2)$ bekezdése alapján a jogi személy jogképessége kiterjed minden olyan jogra és kötelezettségre, amely jellegénél fogva nem csupán az emberhez füződhet. Az öröklési jog ilyen jog.

${ }^{189}$ Vö. Vékás 2014b. 22.; Fábián 2014. 10.

${ }^{190}$ Vékás 2014b. 22.

${ }^{191}$ A házastárs törvényes öröklésére lásd a Ptk. 7:62. §-t, a házastársak és élettársak végrendeleti öröklése vonatkozásában pedig a Ptk. 7:46. §-t. Ennek a szabálynak az érdekessége, hogy az élettárs javára tett végrendeleti rendelkezés (aki egyébként nem törvényes örökös) is hatálytalan, ha az örökhagyó halálakor nem áll fenn az életközösség, továbbá nem volt kilátás annak helyreállítására, valamint nem kívánta juttatásban részesíteni.

${ }^{192}$ Fabó 2014c. 403.

${ }^{193}$ Welser 456.

${ }^{194}$ Kovács P. 479.
} 
érdemtelenségi okok analógia útján bővíthetőek, ${ }^{195}$ míg ez a magyar jogban nem lehetséges a törvény egyértelmü taxatív felsorolása folytán.

e) Az örökös vonatkozásában nem állhat fenn kiesési ok, ${ }^{196}$ azaz ez egy negatív feltétel. ${ }^{197}$ A kiesési okokat a kódex taxatív és kógens jelleggel sorolja fel, miután a hagyatékban való jogutódlás korlátjait képezik. ${ }^{198}$

\subsection{Az Öröklési Rendeletről}

„Az öröklési jog kétségkívül nem meghatározó fontosságú jogterület Európa összenövése szempontjából. Ez a jog más területeire marad, mint például a gazdasági jogéra. Emiatt az öröklési jog eddig nem is szerepelt az EU jogalkotó szerveinek a politikai napirendjén. A gazdasági és - amennyiben lehetséges - a jogi egység azonban csak akkor valósítható meg, ha megszünnek a gazdasági összenövés által különösen érintett jogterületeken fennálló különbségek. Ezek közé a jogterületek közé tartozik az öröklési jog."199 A jogterület szabályozásával kapcsolatos igény ugyanis nem megalapozatlan: „az Európai Unión belüli az államhatárokat „átlépő” öröklési jogi ügyek számát évi 450 000-re, kombinált értéküket pedig több mint 120 milliárd euróra becsülik.”200 Az Öröklési Rendelet javaslatához elkészített hatásvizsgálati jelentés alapján „az Európai Unió területén bekövetkező öröklések 10\%-a nemzetközi jellegü". 201

Az Öröklési Rendelet megalkotása a szabadságon, a biztonságon és a jog érvényesülésén alapuló térség uniós célkitűzésére vezethető vissza, aminek érvényesülése érdekében az Európai Unió intézkedéseket fogad el, ha az a belső piac működéséhez szükséges. Az Európai Tanács, illetve Bizottság is több alkalommal (Tampere - 1999. október 15-16.; intézkedési program - 2000. november 30.; Hágai program - 2004. november 4-5.; Stockholmi program - 2009. december 10-11.) kinyilvánította a polgári és kereskedelmi ügyekben hozott határozatok kölcsönös elismerésének, valamint az egységes kollíziós jogi szabályok megalkotásának szükségességét. Ezt végül fokozatosan az öröklési jogra is kiterjesztették, ezt a

\footnotetext{
195 OGH in JB1 1954, 174; ezzel ellentétesen OGH in NZ 1969,105. idézi: Welser 458.

${ }^{196}$ Lásd Ptk. 7:4. §

197 Vékás 2014b. 23.

${ }^{198}$ Pusztahelyi 13.

${ }^{199}$ Ludwig 3.

${ }^{200}$ Mádl - Vékás 400.; Burandt - Rojahn 1431.

${ }^{201}$ Gothárdi 522-523.
} 
kiterjesztést pedig a jogterület mindennapi élet szempontjából létfontosságú mivoltával indokolták. ${ }^{202}$ A jogalkotás szükségességét indokolta az is, hogy adott esetben egységes szabályok hiányában több tagállam hatóságai is eljárhattak, egymással ellentétes tartalmú határozatot is hozhattak, valamint nincs olyan öröklési joggal kapcsolatos nemzetközi egyezmény, amelynek valamennyi tagállam a részese lenne. ${ }^{203}$ A belső piac is hatékonyabban működhet azáltal, ha megszüntetik azon személyek szabad mozgása előtti akadályokat, akik nehézségekbe ütköznek a határon átnyúló vonatkozású örökléssel összefüggő jogaik érvényesítése során. ${ }^{204}$

A hazánkban is kötelezően, minden további átültetés nélkül alkalmazandó Öröklési Rendelet az ún. Róma-rendeletekre jellemző kollíziós- és a Brüsszelrendeletekre emlékeztető nemzetközi polgári eljárásjogi kérdések mellett az európai öröklési bizonyítvány jogintézményét is megalkotta, ${ }^{205}$ és érint társasági jogi jogviszonyokat is.

Ez a közvetlen hatály ${ }^{206}$ azt jelenti, hogy nem a Rendeletet kell a magyar jogba implementálni, hanem épp ellenkezőleg, az uniós jogi aktusnak megfelelö nemzeti szabályozás szükséges. A Polgári Törvénykönyvet már a Rendelet elfogadott szövegének ismeretében alkották meg, a hagyatéki eljárásról szóló törvénybe illesztettek be az európai öröklési bizonyítvány ${ }^{207}$ kiállításával kapcsolatos, az öröklési rendelethez képest kiegészítő jellegü eljárási szabályokat. ${ }^{208}$ A Rendelet hatására megalkotott jogszabályok közé tartozik még a 2015. évi LXXI. törvény a 650/2012/EU európai parlamenti és tanácsi rendelet 31. cikke szerinti megfeleltetési nemperes eljárásról, valamint egyes igazságügyi tárgyú törvénymódosításokról. Az elnevezésből is következően a törvény egyik része az Öröklési Rendelet egyik jogintézményének, a dologi jogok egymáshoz igazításának ${ }^{209}$ eljárásjogi szabályait alkotta meg más jogszabályok (pl. az Nmjtvr. öröklési kollíziós jogra irányadó rendelkezései) módosításával együtt. Az egymáshoz igazítás azt a célkitűzést igyekszik megvalósítani,

\footnotetext{
202 ÖR (1)-(6) preambulum-bekezdések

${ }^{203}$ Gothárdi 523.

204 ÖR (7) preambulum-bekezdés

205 ÖR (8) preambulum-bekezdés

${ }^{206}$ Blutman 338.

${ }^{207}$ Lásd még Neumayr 262-266.

${ }^{208}$ Hetv. 102/B-102/C. $\S$

209 ÖR 31. cikk: Ha egy személy az öröklésre alkalmazandó jog alapján őt megillető dologi jogra hivatkozik, azonban azon tagállam joga, ahol e jogra hivatkozik, nem ismeri a kérdéses dologi jogot, a szóban forgó jogot - szükség esetén és amennyire lehetséges - az említett állam jogában létező, hozzá legközelebb álló dologi joghoz kell hozzáigazítani, figyelembe véve az adott dologi jog által megvalósítani kívánt célokat és érdekeket, valamint a hozzá füződő joghatást.
} 
ami szerint ahhoz, hogy a kedvezményezettek valamely más tagállamban az öröklés útján keletkezett vagy rájuk átszállt jogokkal élni tudjanak, az ismeretlen dologi jogot a másik tagállamban létező, az eredetihez legközelebb álló dologi joghoz kell igazítani. ${ }^{210}$ Itt kell megjegyezni azt, hogy 2018. január 1-jével lép hatályba a 2017. évi XXVIII. törvény, az új nemzetközi magánjogról szóló törvény, amely tartalmazza a 2015. évi LXXI. törvény által az Nmjtvr.-be iktatott új rendelkezéseket. ${ }^{211}$

Az Öröklési Rendelet alkalmazandósága miatt nem lehet eltekinteni ennek a jogszabálynak a vizsgálatától a lehető legkomplexebb kép kialakításához, éppen ezért tesszük elemzés tárgyává. A Rendelet a kihirdetését követő huszadik napon, 2012. aug. 16-án lépett hatályba, rendelkezéseit azonban - bizonyos kivételekkel, így pl. a Rendeletben foglalt nyilvántartások összeállítása - csak a 2015. augusztus 17-i vagy azutáni halálesetek folytán bekövetkezö öröklésekre kell alkalmazni. ${ }^{212}$

\subsubsection{Az Öröklési Rendelet alapján megállapítható jog}

Az alkalmazandó jog a 20. cikk alapján egyetemesnek minősül, azaz arra tekintet nélkül kell figyelembe venni az így megállapított jogot, hogy az egy tagállam joga-e vagy esetleg az Európai Unión kívüli állam joga. „Ezt a megoldást kritikával lehet illetni, mindenekelőtt azért, mert az Unión kívüli állam jogának alkalmazását sem a belső piac szempontjai, sem praktikus érvek nem indokolják." ${ }^{213}$ Az idézett gondolat alapvetően jogos, de a Rendelet kollíziós szabályait akképp kívánták megfogalmazni, hogy az által annak az államnak a jogát alkalmazzák az öröklési ügyekben, amellyel az örökhagyó (valószínűleg) közelebbi kapcsolatba került. A jogválasztás joga se lenne szabad, ha csak az Európai Unió valamely tagállamának jogát választhatná, érdemes azt megfontolni, hogy jogválasztás esetén az erre irányadó korlátok között az örökhagyó vélhetően olyan állam jogát választja, amellyel az örökösei sem járnak rosszabbul, mintha az egyébként a rendelet által alkalmazni rendelt jogot kellene figyelembe venni.

\footnotetext{
210 (16) preambulum-bekezdés

211 A szóbeli végrendelet és annak visszavonásának alakisági érvényességére lásd 2017. évi XXVIII. törvény 64. §, az állam öröklésére vonatkozó szabályok kisegítő alkalmazására lásd ugyanezen törvény 65. §-át: Ha az öröklésre alkalmazandó jog szerint a belföldi hagyatéknak nincs örököse, a belföldi hagyaték öröklésére a magyar jognak a magyar állam öröklésére irányadó szabályait kell alkalmazni.

212 84. cikk

${ }^{213}$ Mádl-Vékás 405.
} 
Ez a módszer a korábbi kollíziós jogi rendeletekben, valamint a hágai egyezményben is fellelhetö. $^{214}$

Amennyiben a Rendelet másként nem rendelkezik, akkor az öröklés egészére annak az államnak a joga alkalmazandó, amelynek a területén az örökhagyó szokásos tartózkodási helye ${ }^{215}$ elhalálozásának időpontjában volt. Kivételes esetben, ha az eset valamennyi körülménye alapján egyértelmü, hogy az örökhagyó az elhalálozásának időpontjában nyilvánvalóan szorosabban kapcsolódott egy másik államhoz (például munkahely miatt), mint a föszabály szerinti állam jogához, akkor ennek a másik államnak a joga lesz az alkalmazandó jog. ${ }^{216} \mathrm{Az}$ örökhagyó számára nyitva áll annak a lehetősége, hogy választhatja annak az államnak a jogát, amelynek állampolgárságával a választás megtételekor vagy az elhalálozás időpontjában rendelkezik. A többes állampolgársággal rendelkező személy bármelyik állam jogát választhatja, amelynek állampolgárságával a választás megtételekor vagy az elhalálozás időpontjában rendelkezik. E jogválasztásnak kifejezettnek kell lennie végintézkedés formájában, vagy pedig annak a rendelkezésekből ki kell derülnie, például úgy, hogy valamely jogszabály konkrét rendelkezésére utal. Akkor is élhet a jogválasztás lehetőségével valamely személy, ha a választott jog nem teszi lehetővé az öröklési jog területén való jogválasztást. ${ }^{217}$ A Rendelet azért korlátozza a jogválasztást az állampolgárság szerinti állam jogára, hogy biztosítsa az örökhagyó és a választott jog közötti kapcsolatot, valamint annak elkerülése érdekében, hogy az adott jog kiválasztását a kötelesrészre jogosult személlyel szembeni jogos elvárásai érvényesülésének hátráltatása motiválja. ${ }^{218}$

„A Rendelet a hagyaték egységének elvét fogadja el, vagyis a hagyaték jogi sorsát egyetlen állam jogának rendeli alá" ${ }^{219}$ jogbiztonsági okok és a hagyaték felosztásának elkerülése érdekében. ${ }^{220}$ Ezt az elvet már az 1989. évi hágai öröklési egyezmény is ismerte. ${ }^{221}$ A nemzetközi magánjog tudományában kialakult másik doktrína a hagyaték megosztásának elve, ahol mind az ingatlanra (erre fő szabály szerint a fekvési hely joga az irányadó), mind az ingó hagyatékra (amelyekre az örökhagyó

\footnotetext{
${ }^{214}$ Lagarde 128-129.

215 A szokásos tartózkodási hellyel kapcsolatban bővebben lásd Lagarde 34-35., Frimston 68-70., Odersky 4-5.

${ }^{216}$ ÖR 21. cikk, Vö. ÖR (23)-(25) preambulum-bekezdések

${ }^{217}$ ÖR (39)-(40) preambulum-bekezdés, ÖR 22. cikk (1)-(2) bek.

218 ÖR (38) preambulum-bekezdés

${ }^{219}$ Mádl - Vékás 404., Szőcs 34.

${ }^{220}$ ÖR (37) preambulum-bekezdés

${ }^{221}$ Lagarde 33.
} 
halálakor érvényes személyes joga vonatkozik) eltérő az alkalmazandó jog. ${ }^{222}$ Mindkét tételnek megvannak a maga előnyei és hátrányai: az egyetlen jogrend alá utalás előnye az, hogy nem kell különböző jogrendszerek jogi kategóriáit összemérni, (például mi milyen vagyontárgynak minősül pontosan, milyen jogok illetik meg az örökösöket, az elhunyt házastársát), ahogy a Rendelet is rendelkezik ilyen szabályokról. Ezzel szemben a hagyaték megosztásának elve tipikusan az ingatlanhoz köti az egyik ország jogrendszerét, amely nem sérti más ország szuverenitását (nem kell a nem fekvés szerinti állam rendelkezéseit végrehajtani, így pl. az örökösök tulajdonjogát bejegyezni az ingatlan-nyilvántartásba). Az Öröklési Rendelet tiszteletben tartja a tagállamok azon jogát, hogy az általuk vezetett (ingóra és ingatlanra vonatkozó) nyilvántartásukba szabadon bejegyezhessék az örökléssel kapcsolatos változásokat, meghatározhassák a bejegyzés joghatásait, mert ezekre a kérdésekre nem terjed ki a hatálya. ${ }^{223}$

Ezzel összefüggő kérdés a jogi személyek személyes jogának meghatározására irányadó kapcsoló tényezők, a bejegyzés és a székhely elvének ${ }^{224}$ mibenléte. Ezek az elvek az egyes társasági formákra irányadó öröklési jogi szabályok alapjait is megszabják, azaz a társasági szerződéses tartalom kialakításának lehetőségeit és a vonatkozó kógens szabályokat is. Ezeknek az elveknek az egységesítése a teljes Európai Unióra nézve nagy előnnyel járhatna, ugyanekkor ennek gyakorlati megvalósulására kis esélyt látok; ugyanis nehezen születne konszenzus a tagállamok között abban a kérdésben, melyik elvet fogadják el.

\subsubsection{Az öröklés fogalma az Öröklési Rendeletben}

A Rendelet autonóm fogalmakat használ, ${ }^{225}$ ezeket pontosan meg is határozza a korábbi európai bírósági döntésekre is támaszkodva ${ }^{226}$ - és az öröklésre is alkotott egy fogalmat: ${ }^{227}$ az öröklés nem más, mint az örökhagyó vagyonában bekövetkező jogutódlás; a vagyontárgyak, jogok és kötelezettségek haláleset miatti átszállásának valamennyi formáját magában foglalja, akár végintézkedés, akár törvényes öröklés

\footnotetext{
${ }^{222}$ Nagy Cs. I. 147.

${ }^{223}$ ÖR (18)-(19) preambulum-bekezdés

${ }^{224}$ Nagy Cs. I. 62-65.; Mádl - Vékás 216-224.

225 Gombos 81 .

${ }^{226}$ C-513/03. Héritiers de M. E. A. van Hilten - van der Heijden vs. Inspecteur van de Belastingdienst, C256/06. Theodor Jäger vs. Finanzamt Kusel-Landstuhl, C-11/07. Hans Eckelkamp és társai vs. Belgische Staat, C-25/10. Missionswerk Werner Heukelbach eV vs. État belge, C-132/10. Olivier Halley és társai vs. Belgische Staat, C-31/11. Marianne Scheunemann vs. Finanzamt Bremerhaven

${ }^{227}$ ÖR 3. cikk (1) bek. a) pont
} 
révén történő átszállás útján. Ezekhez hasonló fogalmi elemeket már a preambulumban is olvashattunk, a Rendelet szövegébe történő becikkelyezésével teljes értékü jogi normává váltak. A (47) preambulum-bekezdés szerint az öröklésre alkalmazandó jognak meg kell határoznia bármely adott öröklés kedvezményezettjeit, az örökösök és a hagyományosok mellett megemlíti a kötelesrészre jogosultat is, mint kedvezményezettet. A jogalkotónak nyilvánvalóan az volt a célja, hogy az öröklési jogviszonyok teljes rétegét lefedje.

A Rendelet alkotását megelőző bírói döntések közül több a határokon átnyúló örökléssel összefüggő öröklési illetékekkel, illetve az azokkal kapcsolatos kedvezmények igénybevehetőségével foglalkozik. Ez a kérdés összefügg a tőke szabad mozgásának uniós célkitűzésével, mert a tagállami szabályozások különbséget tettek az illetékek kapcsán aszerint, hogy az örökhagyó kivándorolt-e az állampolgárságának megfelelő államból, és ettől számítva mennyi idő telt el; ${ }^{228}$ az eltérő tagállamokban fellelhető egyes vagyontárgyak (így például termőföld) forgalmi értékének megállapítása; ${ }^{229}$ egy tagállam állampolgárságával bíró természetes személy által végrendeleti öröklésben részesített más tagállamban székhellyel rendelkező jogi személy által kedvezményes adómérték igénybevételének jogosultsága, ${ }^{230}$ valamint a szintén más tagállamban bejegyzett részvénytársaság részvényei értékelésének elévülése, és az értékelést alapul vevő öröklési illeték meghatározása ${ }^{231}$ vonatkozásában.

Szintén öröklési illetékmentességhez kapcsolódó kérdést vetett fel a C-31/11. számú ügy, amely ügynek a társasági joggal is szorosabb viszonya van. A német tagállami szabályozás alapján az illetékkedvezmény esetleges igénybevételének feltétele a társaságban fennálló több mint 25\%-os közvetlen tőkerészesedés, így a tőketársaságban fennálló ilyen részesedés lehetővé teszi, hogy irányítást biztosító befolyást gyakoroljanak annak döntéseire, és meghatározzák annak tevékenységét. A német kormánynak az ügyben kifejtett álláspontja szerint az alapeljárásbeli nemzeti rendelkezések által elöírt illetékkedvezmények jogpolitikai célja különösen az volt, hogy a jelentős társasági részesedések örököseit a társaság ügyvezetésében való részvételre ösztönözzék abból a célból, hogy végeredményben biztosítsák a vállalkozás fennmaradását és a munkahelyek megtartását. Az nem volt vitatott, hogy az örökhagyó

\footnotetext{
${ }^{228} \mathrm{C}-513 / 03$.

${ }^{229} \mathrm{C}-256 / 06 ., \mathrm{C}-11 / 07$

${ }^{230} \mathrm{C}-25 / 10$.

${ }^{231} \mathrm{C}-132 / 10$.
} 
a szóban forgó társaság tőkéjében 100\%-os részesedéssel bírt, amely folytán tagadhatatlan, hogy irányítást biztosító befolyást tudott gyakorolni a társaság döntéseire, és meg tudta határozni annak tevékenységét, de a társaság kanadai székhelye miatt eltérő megítélés alá esett a konkrét tényállás. Az olyan tagállami szabályozás, amely az öröklési illeték kiszámítása során a harmadik államban székhellyel rendelkező tőketársaságban fennálló részesedésben megtestesülö hagyaték esetén kizárja bizonyos illetékkedvezmények alkalmazását, míg ugyanezeket a kedvezményeket megadja az efféle részesedést tartalmazó hagyaték esetében, ha a társaság székhelye valamely tagállam területén található, döntően a letelepedés szabadságát érinti, ha e részesedés lehetővé teszi a birtokosa számára, hogy irányítást biztosító befolyást gyakoroljon az érintett társaság döntéseire, és meghatározza annak tevékenységét. E cikkek céljukat tekintve nem alkalmazandóak az olyan társaságban birtokolt részesedés esetére, amelynek a székhelye harmadik államban található. Azért lehet egyetérteni a Bíróság álláspontjával, mert a társaság székhelye nem valamely uniós tagállamban található meg, így egyik szabadság sem sérülhet, ha a korlátozó (jelen ügyben illetékfizetés alól mentességet nem adó) szabályok érvényesülnek, és ezek harmadik államot érintenek.

Az öröklés fogalmától eltérően a Rendelet nem határozza meg a hagyaték fogalmát, ugyanakkor elfogadható az az álláspont, miszerint a jogszabály alkalmazása során nem fog aggályt okozni ennek hiánya, ${ }^{232}$ ugyanis a tagállami jogszabályok, illetve a bírói gyakorlat az ide tartozó vagyontárgyak körét pontosan meghatározzák.

\subsubsection{A Rendelet tárgyi hatálya}

A Rendelet alapján megállapított, valamint a jogválasztás révén kijelölt jog az öröklés egészére irányadó, a Rendelet ehhez képest e körben mégis ad egy példálózó felsorolást. Ebben megemlíti, hogy az alkalmazandó jog vonatkozik többek között az öröklés megnyílásának okaira, időpontjára, helyére, a kitagadásra, az érdemtelenségre, a hagyatéki tartozásokért való felelősségre. ${ }^{233}$ Az Öröklési Rendelet szempontjából egyértelmü, hogy az alábbi pont szerepel a felsorolásban: a fentiek alapján megállapított jog irányadó a hagyatékba tartozó vagyontárgyak, jogok és kötelezettségek átszállására az örökösökre és adott esetben a hagyományosokra, beleértve az örökség vagy a

\footnotetext{
${ }^{232}$ Frimston 64.

${ }^{233}$ ÖR 23. cikk, vö. ÖR (42) preambulum-bekezdés
} 
hagyomány elfogadásának, illetve visszautasításának feltételeit és joghatásait is. ${ }^{234}$ Magát a Rendeletet is azért alkották meg, hogy azon tagállamokban, melyekre nézve alkalmazandó ez a jogi instrumentum, egységesen, lehetőleg ugyanazt a jogot tudják figyelembe venni az egyes esetekben. Ez az egységesség jelenti egyrészt azt, hogy a teljes öröklési jogviszonyra, annak minden aspektusára vonatkozzon az így megállapított jog, ezzel együtt arra is, hogy a hagyaték megnyílásától egészen annak felosztásáig kiterjedjen, ${ }^{235}$ másrészt azt, hogy azonos körülmények között ugyanaz a jog kerüljön alkalmazásra bármely tagállam bármely, az öröklést tekintve (az öröklési rendelet szerint is) hatáskörrel rendelkező szervére.

Az öröklési jog egyik fő kérdése, az ún. kedvezményezettek meghatározása ${ }^{236}$ után az, hogy az örökhagyót megillető vagyoni jogok és terhelő kötelezettségek milyen módon háramlanak a jogutód(ok)ra. A Rendelet magyar nyelvű szövege az átszállás szót használja ebben a kontextusban, ${ }^{237}$ igaz, ez a Rendelet német és angol nyelvü változatában megtalálható kifejezések (der Übergang, illetve transfer) magyar fordítása, de ezt a kifejezést öröklési jogi kontextusban csak a hatályon kívül helyezett 2006. évi Gt. használta a korlátolt felelősségű társaságok üzletrészeinek öröklésekor. Ebben az értelemben további megszorítás nélkül igaz volt az alábbi fogalom: az üzletrész átszállása a tagok személyében nem jogügyleti jogcímen bekövetkező alanyváltozás, jogutódlás. ${ }^{238}$ A Gt. mind a természetes, mind a jogi személy jogutódlására használta ezt a terminus technicust, ${ }^{239}$ a Ptk. azonban már csak a jogi személy átalakulásakor, egyesülésekor, szétválásakor, vagy jogszabály alapján az üzletrész tekintetében bekövetkezett jogutódlás esetén ${ }^{240}$ használja az átszállás kifejezést, míg természetes személy esetén az üzletrész örökléséről rendelkezik.

\subsubsection{A rendelet tárgyi hatálya alól kizárt esetek}

A rendelet a tárgyi hatálya alól bizonyos kérdéseket kizár, így az nem alkalmazható a polgári jog öröklési jogtól eltérő területeire, ${ }^{241}$ továbbá például az adó-, vám- és közigazgatási ügyekre sem. ${ }^{242}$

\footnotetext{
234 ÖR 23. cikk (2) bek. e) pont

${ }^{235}$ Lagarde 38.

${ }^{236}$ (47) preambulum-bekezdés

${ }^{237}$ Uo.

${ }^{238}$ Papp 2011b. 412-413.

${ }^{239}$ Gt. $128 . \S$

${ }^{240}$ Ptk. 3:170. $\$$

241 ÖR (11) preambulum-bekezdés
} 
Nem terjed ki a jogi instrumentum hatálya az örökléstől eltérő módon létrehozott és átszállt vagyoni jogokra, érdekeltségekre és vagyontárgyakra, mint például az ajándékokra, a közös tulajdonra a túlélő tulajdonostárs várományi jogával, a nyugdíjprogramokra, a biztosítási szerződésekre és az ezekhez hasonló, élők közötti megállapodásokra. ${ }^{243}$ Ebből a példálózó felsorolásból látható, hogy itt a jogalkotó olyan tulajdonosváltozásokra gondolt, amelyek nem öröklés útján következnek be, valamint az ajándék kivételével a jogszerzőnek nincs feltétlenül kapcsolata öröklésen kívüli jogviszonnyal, hanem a szerzés az elhalálozott személy korábbi jogügyletén (pl. biztosítási szerződés, ha azt az örökhagyó maga kötötte meg), vagy például társadalombiztosítási jogviszonyán (nyugdíj esetében) alapul.

\subsection{A társasági jog és az Öröklési Rendelet viszonya}

Ehhez képest még speciálisabb kivételi kört jelent, miszerint a Rendelet nem alkalmazandó a társasági jog, valamint a más jogi személyekre vagy jogi személyiség nélküli szervezetekre irányadó jogszabályok által szabályozott kérdésekre, mint például a társaságok, valamint a más jogi személyek, vagy jogi személyiség nélküli szervezetek létesítő okiratában vagy alapszabályában foglalt záradékokra, amelyek tagjaik halála esetére rögzítik a részesedés sorsát. ${ }^{244}$ A fentiek azt is jelentik, hogy a jelenlegi Ptk.-beli szabályozást nem kell ehhez a rendelethez igazítani, annak szabályai továbbra is irányadóak. A magyar jogot megvizsgálva ez a kérdéskör azért sem tartozik a Rendelet hatálya alá, mert az, hogy a bármely társaságbeli részesedés örökölhető-e, és ha igen, annak vannak-e korlátai, nem az öröklési jog, hanem a társasági jog szabályozási körébe tartozik. $^{245}$

Tehát azt, hogy adott kérdés az öröklési joghoz vagy a társasági joghoz tartozike, a határon átnyúló öröklési ügyben illetékes bíróság joga fogja eldönteni, ${ }^{246}$ de mindemellett figyelembe kell venni az Öröklési Rendelet 30. cikkét is. Eszerint ha bizonyos ingatlanok, vállalkozások vagy más, különleges vagyonkategóriák fellelhetősége szerinti állam joga olyan különös szabályokat tartalmaz, amelyek gazdasági, családi vagy társadalmi megfontolások miatt e vagyontárgyak öröklésével kapcsolatos vagy arra kiható korlátozásokat állapítanak meg, az említett különös

${ }^{242}$ ÖR 1. cikk (1) bek.

${ }^{243}$ ÖR 1. cikk (2) bek. g) pont

${ }^{244}$ ÖR 1. cikk (2) bek. h) pont

${ }^{245}$ Mádl - Vékás 404., Paulus 9.

${ }^{246}$ Vö. Paulus 9. 
szabályokat alkalmazni kell az öröklésre, amennyiben a szóban forgó állam joga szerint az említett szabályokat az öröklésre alkalmazandó jogra való tekintet nélkül alkalmazni kell. ${ }^{247}$ Annak a vizsgálata során, hogy valamely kérdés a társasági joghoz vagy az öröklési joghoz tartozik-e, ugyanarra a megállapításra juthatunk, mint a 1. cikk (2) bekezdés i) pont szerinti társaságok, valamint más jogi személyek vagy jogi személyiség nélküli szervezetek megszünése, megszüntetése és egyesülése tekintetében is, azaz az illetékes bíróság jogát kell figyelembe venni. ${ }^{248} \mathrm{~A}$ magyar jog szerint az utóbbi csoportok egyértelmúen a személyek jogához tartoznak, ezen belül a gazdasági társaságok vonatkozásában a társasági joghoz, ezáltal ezek az Öröklési Rendelet tárgyi hatályán kívül esnek.

A társasági jogi kérdések kivétele a kollíziós rendelet hatálya alól már a Róma I. rendeletben is megjelent. A társasági részesedések öröklése, a megváltás iránti igény keletkezésére továbbra is a társasági szerződés rendelkezései lesznek irányadóak, ugyanez lesz igaz a társaság továbbfolytatására, valamint a társaságba történő belépésre, a társasági statútumok elbírálására pedig a nemzeti kollíziós jogokat kell figyelembe venni. $^{249}$

Gyekiczky Tamás álláspontja szerint ${ }^{250}$ „nem világos, a Rendelet tárgyi hatálya kiterjed-e azokra az esetekre, amikor a társasági szerződés a tag halála esetére részletesen rendelkezik a tag társasági részesedésének öröklési sorsáról, vagy csak azok az esetek maradnak kívül, amikor a tag halála a társasági szerződés szerinti és a társasági jog által szabályozott társasági jogutódlást vált ki. A Rendelet a második értelmezést támogatja, amit az öröklés meghatározásával támaszt alá." Véleményem szerint azonban a Rendelet hatálya a szöveg értelmezése alapján nem terjed ki arra az esetre sem, ha a tag halála esetére részletesen rendelkezik a társasági szerződés. Az Öröklési Rendelet úgy fogalmaz, hogy a létesítő okiratban foglalt azon záradékokra sem terjed ki a Rendelet hatálya, amelyek a tagok halála esetére rögzítik a részesedés sorsát, ebbe azonban beleérthető az öröklési sors is. Ugyan a Rendeletbeli öröklés fogalom valamennyi jog és kötelezettség haláleset miatti átszállásának valamennyi formáját le kívánja fedni, de az öröklési jog és a társasági jog kapcsolatánál az öröklési jogi

\footnotetext{
${ }^{247}$ ÖR (54) preambulum-bekezdés; Frimston 53.

248 Frimston 53.

${ }^{249}$ Burandt - Rojahn 1434. Így például a magyar nemzeti jog vonatkozásában 2018. január 1 -jétől a jogi személyekre vonatkozó kollíziós jog megállapítására a 2017. évi XXVIII. törvény 22. §-át. A társaságok honosságának uniós jogi megítélésének egyik sarkköve a magyar érintettségü Cartesio-ügy (C-210/06.). ${ }^{250}$ Gyekiczky 2-3.
} 
szabályokat felülírja a társasági jog, a Rendelet ezt figyelembe véve zárta ki a hatálya alól a társasági részesedéseket.

Ma már könnyen bekövetkezhet az, hogy egy adott gazdasági társaságnak ne csak belföldi tagjai legyenek. Ha természetes személyekről van szó, úgy ezek halála szintén felveti az Öröklési Rendelet alkalmazandóságát. Figyelemmel arra, hogy a társasági jogi kérdések a Rendelet tárgyi hatályán kívül maradnak, a társasági szerződésben kijelöltek, illetve az arra vonatkozó jog szerint valósul meg a társasági részesedésben jogutódlás, a Rendelet alapján kijelölt jog pedig azt határozza meg a társasági szerződés eltérő rendelkezésének hiányában, hogy ki minősül az örökhagyó tag örökösének, azaz ki kerülhet öröklés jogcímén az elhunyt tag helyébe.

Az osztrák jogban ezek alapján a rendelet tárgyi hatálya alól ki van véve például az OG és a KG vonatkozásában a társaság megszűnésére, illetve annak folytatására irányuló rendelkezések, míg az ÖR hatálya alá tartozik az UGB 40. §-a szerinti, az örökösöknek a kereskedő halála esetén a vállalkozás folytatásának szabályozása. ${ }^{251}$

\subsection{A hagyatéki eljárás és a gazdasági társaságok}

A gazdasági társasági részesedéseknek speciális szerep jut a hagyatéki eljárásokban, ami több részletszabályban is megjelenik. A hagyatéki eljárás részletes ismertetésétől eltekintve, ${ }^{252}$ a sporadikusan elhelyezkedő rendelkezéseket kívánom ismertetni.

Az első ilyen az a rendelkezés, miszerint a hagyatékot kötelező leltározni akkor, ha a hagyatékban a cégjegyzékbe bejegyzett gazdasági társaságban, illetve szövetkezetben (a további szabályok is tartalmazzák a szövetkezetre történő utalást, miután azonban az értekezésnek nem tárgya a szövetkezeti jog, erre külön már nem utalok) a fennálló tagi (részvényesi) részesedés van, azaz a leltározásnál nem kell figyelembe venni az előtársasági létszakaszt (ennek az időszaknak a rendezését lásd a 4.1.1. pontban), illetve a cégjegyzékből már törölt gazdasági társaságban fennállt részesedést. ${ }^{253}$ Anka Tibor kérdésként veti fel, ha a hagyatéki eljárás alatt szünik meg a társaság, helye van-e a Hetv. 78. §-a szerint a hagyatéki eljárás megszüntetésének, miután már nem áll fenn az a körülmény, ami a hagyaték leltározását kötelezővé tette.

\footnotetext{
251 Traar 363.

${ }^{252}$ A hagyatéki eljárásról szóló törvény magyarázatára lásd Anka Tibor müvét: Anka 2014a.

${ }^{253}$ Anka 2014a. 67-68.
} 
Erre azt a - helyeslendő - választ adta, hogy miután alapvetően a hagyatéki eljárás tárgya a hagyaték, ennek az elemeit pedig a hagyaték megnyílása, azaz az örökhagyó halála határozza meg, ha nincs is másik vagyontárgy, az eljárást be kell fejezni. A változást azt fogja eredményezni, hogy a hagyatékátadó végzés milyen anyagi jogi jogkövetkezményekkel járhat. ${ }^{254}$

Másik szabály az, miszerint ha a leltár szerint a hagyatékban a Ptk. gazdasági társaságokra vonatkozó rendelkezéseiben meghatározott társasági részesedés van, amíg a leltárt meg nem küldték a közjegyzőnek, a jegyző, azt követően - a közjegyző biztosítási intézkedésként a tagsági jogok gyakorlására a társaság vagy a müködésében érintett más személy, szervezet indokolt kérelmére ügygondnokot rendelhet ki, ha az intézkedés nyilvánvalóan a társasági vagyon megóvása vagy a társaság működésének biztosítása érdekében szükséges. Ha e minőségét arra használja fel, hogy saját tagi érdekei erősítésére a társaság belső viszonyait átalakítsa, megsérti a jóhiszemüség és tisztesség követelményét, és ez a joggal való visszaélés tilalmába ütköző módon megszavazott taggyülési határozatok hatályon kívül helyezésére adhat alapot. ${ }^{255} \mathrm{Az}$ ügygondnok vagyoncsökkenést eredményező határozat hozatalát a szavazatával nem támogathatja és a hagyaték terhére vagyoni kötelezettségeket nem vállalhat, kivéve, ha ezzel az érintett társaságot és az örökösként érdekeltet nyilvánvaló károsodástól óvja meg. ${ }^{256}$ A vagyoncsökkenés nem jelenti azt, hogy a társaság vagyona az ilyen határozat révén ne változhatna, a törvény ugyanis nem zárja ki azt a lehetőséget, hogy valamely vagyontárgy helyébe egy, az annak értékének megfelelő másik lépjen, csak a részben vagy egészben ingyenes vagyonátruházás tilalmazott, kivétel képez, ha ezzel károsodástól óvja meg a társaságot vagy az örökösként érdekeltet. ${ }^{257} \mathrm{~A}$ korábbi hagyatéki eljárási szabályokban nem volt ilyen tartalmú rendelkezés, de már a jogirodalomban is megjelent az az álláspont, mely a hatályos törvényben is szerepel. ${ }^{258}$ A szabály alkalmazására találunk példát a joggyakorlatban. ${ }^{259}$

További ilyen szabály az, miszerint ha van végrendelet, akkor ennek végrehajtójának jogait és kötelezettségeit a végrendelet határozza meg. Amennyiben erre nem került sor, akkor más jogok és kötelezettségek mellett az is idetartozik, hogy a hagyatéki vagyon kezelésére irányuló jogkörében a hagyatékot birtokba vegye, és a

\footnotetext{
${ }^{254}$ Anka 2014a. 68.

255 BDT 2012. 2827., idézi Barta 2017. 91.

${ }^{256}$ Hetv. 32. § (2) bek.

257 Anka 2014a. 101-102.

${ }^{258}$ Harsányi - Ujváriné - Miskolczi Bodnár 227.

${ }^{259}$ FIT-H-PJ-2014-284.
} 
hagyaték megnyílásával az örökösre átszállt társasági tagsági jogokat gyakorolja. ${ }^{260}$ Ekkor tehát nem a jegyző vagy a közjegyző által kirendelt ügygondnok látja el ezt a feladatot. $^{261}$

Amennyiben adat merül fel arra vonatkozóan, hogy gazdasági társaságban lévő részesedés van, akkor a hagyatéki eljárás során be kell szerezni az örökhagyó halála időpontjában hatályos társasági szerződést. ${ }^{262}$

\footnotetext{
${ }^{260}$ Hetv. 99. § (1) bek., Hetv. 99. § (2) bek. c) pont cc) alpontja

${ }^{261}$ Anka 2014a. 319.

${ }^{262}$ Tóth 6.
} 


\section{Az öröklési jog megjelenése az egyes gazdasági társaságoknál}

A társaság tagjának halála nemcsak öröklési jogi kérdéseket vet fel, hanem magának a társaságnak a létére is kihatással lehet. Ezért érdemes a vonatkozó szabályokat megvizsgálni a gazdasági társaságok dinamikájának, azaz az egyes létszakaszok szempontjából (4.1.). Az ún. statikus rész tartalmazza azon tudnivalókat, amelyek segítik az eligazodást abban az esetben, ha a társaság tagja meghal, és a hagyatékban megjelenő társasági részesedés sorsát hivatottak elrendezni (4.2.).

\subsection{A tag halálának társaságra gyakorolt hatása}

\subsubsection{Cégbejegyzés elött}

A gazdasági társaságok alapításának első mozzanata a társasági szerződés közokiratba, vagy ügyvéd, illetve valamely alapító kamarai jogtanácsosa által ellenjegyzett magánokiratba foglalása, amitől számított 30 napon belül be kell nyújtani a cégbejegyzés iránti kérelmet a cégbírósághoz. ${ }^{263} \mathrm{Ha}$ az ellenjegyzés és a benyújtás közötti időszakban hal meg valamelyik leendő tag, a helyzet rendezése a többalanyú kötelmekre irányadó szabályok alapján történik meg. A vagyoni hozzájárulás szolgáltatása osztott kötelezettségnek minősül, ${ }^{264}$ miután minden leendő tag - a közös tulajdonú üzletrész esetétől eltekintve - saját maga kell, hogy teljesítse vagyoni hozzájárulását. Ez akkor lesz igaz, ha nem volt előtársasági szakasz, így a szerződéses pozícióbeli öröklést kell megvizsgálni. Figyelembe kell venni egyúttal a Ptk. 6:3. § c) és d) pontját, miszerint a kötelem megszünik a kötelezett, illetve jogosult (hiszen ahogy a társaság tagjai, úgy az előtársaság tagjai is egyszerre jogosultak és kötelezettek) halálával, valamint jogutód nélküli megszünésével, ha a kötelezettsége személyesen teljesíthető szolgáltatás nyújtására irányult, illetve ha a szolgáltatást - annak jellegénél fogva - kifejezetten részére kellett nyújtani. Igaz az, hogy a kötelezett vagy a jogosult halála rendszerint nem szünteti meg a kötelmet, ${ }^{265}$ amennyiben a társaság felé pénzszolgáltatásra kötelezett volt az örökhagyó, úgy az az örökösöket is terheli, viszont

\footnotetext{
${ }^{263}$ Ptk. 3:95. § (2) bek., 3:100. § (1) bek.

${ }^{264}$ Ptk. 6:28. § (2) bek.

265 Osztovits 35., Vékás 2014a. 1306-1307.
} 
ha olyan apportról van szó, ami szorosan kapcsolódik az örökhagyóhoz, tehát ami a 6:3. $\S$ c) és d) pontjai alá illeszthető, az örökösök szabadulnak attól a kötelemtöl.

Ha az örökhagyó már szolgáltatta a vagyoni betétjét, úgy az a leendő társaság vagyonát képezi, de függő jogi helyzet áll fenn a cégbejegyzésig. Az örökösökkel való elszámolás mindenféleképpen szükséges.

Az eredeti alapítással létrejött gazdasági társaságok létezésének első szakasza az előtársasági létszakasz lehet. (Érdekesség, hogy az osztrák és a német társasági jog még az előtársasági létszakasz előtt is ismer egy stádiumot, az ún. Vorgründungsgesellschaftot, azaz előalapítási társaságot, amely egy - csak - korlátolt felelősségű társaság alapítására irányuló előszerződés, ${ }^{266}$ azonban e társaság által szerzett jogok és kötelezettségek nem szállnak át automatikusan az előtársaságra. ${ }^{267} \mathrm{~A}$ Gt. 15. § (1) bekezdése, valamint a Ptk. 3:100. § (1) bekezdése szerint a gazdasági társaság a társasági szerződés ügyvédi vagy kamarai jogtanácsosi ellenjegyzésétől vagy köz(jegyzői) okiratba foglalásától a létrehozni kívánt gazdasági társaság előtársaságaként müködhet. Az előtársaság nem különbözik az alapítandó gazdasági társaságtól, hanem a létrehozandó társasággal azonos, annak átmeneti, feltételes, létrejövetelt megelőző minősége. ${ }^{268} \mathrm{Az}$ előtársaság cégneve alatt jogképes, a nyilvántartásba vételi kérelem benyújtását követően üzletszerű gazdasági tevékenységet folytathat, müködését illetően annak a társaságnak a szabályait kell rá alkalmazni, amilyen formában létre szeretnék hozni, a törvényben meghatározott eltérésekkel. ${ }^{269}$ „Elvileg bekövetkezhet az előtársaság tagjainak személyében történő változás öröklés következtében, de csak az adott társasági formára vonatkozó Gt. ${ }^{270}$ [Ptk.] szabályok szerint, vagyis pl. akkor, ha közkereseti társaság, betéti társaság esetében az örökös a többi taggal való megállapodás alapján az előtársaság tagjává válik. Kft.-nél pedig az előtársasági létszakban még nem is beszélhetünk üzletrészről, amely átszállhatna a jogutódra." ${ }^{, 271}$ Ehhez hozzá kell tenni azt, hogy a törvény nem tilthatja meg azokat a tagváltozásokat, amelyek más törvényi rendelkezések folytán szükségképpen előállnak. Így egy természetes személy tag halála a tagok személyében mindenképpen változást

\footnotetext{
${ }^{266}$ Papp 1993. 630-631.

${ }^{267}$ Brünner - Pasrucker 45-46.

${ }^{268}$ Papp 2011b. 101.

${ }^{269}$ Gt. 16. § (1) bek., Ptk. 3:101. § (1) bek.

270 1997. évi CXLIV. tv.

${ }^{271}$ Wellmann 4.
} 
eredményez, hiszen a meghalt tagnak már nem lehetnek társasági jogi jogosultságai vagy kötelezettségei, ${ }^{272}$ figyelemmel arra is, hogy már nem jogképes.

Wellmann György álláspontjához képest eltérő véleményt fogalmazott meg az előtársaságként működő korlátolt felelősségü társaságokkal kapcsolatban Koday Zsuzsanna: úgy véli, ha a társasági szerződés érvényes, semmisségi ok kiküszöbölésére sincs szükség, akkor a kft.-t az örökhagyó tagsági jogviszonyával fogják bejegyezni a cégjegyzékbe, ezzel az üzletrész létre fog jönni, ami már a hagyaték tárgyát fogja képezni. Ha a cégbejegyzés nem valósul meg, akkor a törzsbetét, illetve az előtársaság müködésének eredményéből a törzsbetétre jutó pénzösszeg lesz örökölhető. ${ }^{273}$ Meglátásom szerint jogszabályi felhatalmazás hiányában e megoldási javaslat alkalmazása nem teljesen aggálymentes, ellentmondana a cégjegyzék közhitelessége elvének, amennyiben az eljáró cégbíróság tudomást szerez arról, hogy meghalt taggal kívánnak bejegyezni egy társaságot. Már csak azért sem tartható védhetőnek ez a meglátás, mert, ahogy az említésre került, az elhunyt személy már nem jogképes, így jogokat már nem szerezhet, kötelezettségeket sem vállalhat, azaz nem lehet gazdasági társaság tagja sem. Ez utóbbi indok egészen más megvilágításba helyeződik, ha a cégbíróság nem értesül valamely alapító természetes személy haláláról, de a pontos jogkövetkezmények megállapítását ilyen esetleges ténytől nem szabad függővé tenni, mindezekre figyelemmel lehet egyetérteni a Wellmann Györgytől idézett megállapításokkal.

A Ptk.-beli szabályozás vizsgált pontja a Gt.-hez képest ekként módosult: „a tagok személyében kizárólag jogszabályon alapuló változás következhet be."274 Álláspontom szerint az öröklés ebbe a körbe tartozik. Az örökös az új szabályozás fényében is taggá válhat az előtársaságban, amennyiben akar, a taggá válásra továbbra is a megalapítandó társaságra irányadó rendelkezések alapján kerülhet sor. Az előtársasági létszakasz - köszönhetően az elektronikus, valamint az egyszerűsített cégbejegyzési eljárásnak - már egyre rövidebb időtartamú, de nem teljesen mellőzhetetlen, mert lehetséges jelentősebb időbeli eltérés a létesítés elhatározása (a társasági szerződés okiratba foglalása) és a nyilvántartásba vétel között, így szükséges ennek az időszakasznak a jogi rendezése. ${ }^{275}$ Ehhez képest hosszabb időt vehet igénybe - az eljárási határidők összeszámításával - a „hagyományos” cégbejegyzési eljárás, amely a

\footnotetext{
${ }^{272}$ Kisfaludi - Szabó 234.

273 Koday 8.

${ }^{274}$ Ptk. 3:101. § (2) bek. a) pont

${ }^{275}$ T/7971. számú törvényjavaslat indokolásából
} 
cégbejegyzési kérelem beérkezésétől számítva akár 19 munkanap is lehet. Ez alatt az idő alatt is müködhet előtársaságként a leendő gazdasági társaság. Az előtársaság részéről nem lehet kikényszeríteni az örökösök részvételét, mert az ellentmondana a vállalkozási és társulási szabadság alapelvének. ${ }^{276}$ Mindenki maga, saját személyében döntheti el a társaságbeli részvételt.

Amennyiben a társaság nem müködik előtársaságként, valamelyik tag halála esetén szintén a többalanyú kötelmekre irányadó szabályok alapján rendezik a helyzetet.

A cégbejegyzési eljárás alatt is bekövetkezhet valamely tag halála, amely az eljárás félbeszakadását jelenti, és mindaddig nem folytatható, amíg a cég egyedüli, elhalt tulajdonosának (!) - s egyben ügyvezetőjének - örököse új ügyvezető választásával a félbeszakadást előidéző okot meg nem szünteti. ${ }^{277}$ A döntésben foglaltak szerint az egyébként speciális formának minősíthető egyszemélyes kft cégbejegyzési kérelmét elutasították, a fellebbezési eljárás során meghalt az egyetlen tag, és a jogi képviselő kérte a cégbejegyzési eljárás megszüntetését. A másodfokon eljáró Legfelsőbb Bíróság nem szüntette meg az eljárást, álláspontja szerint a jogi képviselő megbízatása a tag halálával megszünt. Polgári eljárásjogi szempontból félbeszakadt az eljárás, a cégeljárás a jogutód megválasztásáig, illetőleg a cégbejegyzési eljárásban történő fellépéséig félbeszakad. Az új ügyvezető megválasztására sor kerülhet a társaság tagjainak döntése alapján, de ennek elmaradása esetén törvényességi felügyeleti eljárás során kell a kiszabott szankciók alkalmazásával kikényszeríteni a félbeszakadás megszüntetését meghatározott időn belül. A Legfelsőbb Bíróság megállapította, hogy az ügy speciális jellegét az okozta, hogy a meghalt személy nemcsak a társaság egyedüli törvényes képviselője, hanem egyedüli tulajdonosa (helyesen: tagja) is volt. Így nem volt olyan szerv vagy személy, amely (aki) az új ügyvezetőt megválaszthatta volna. Ugyanakkor nem zárható el az elhalt tag jogutódja, örököse attól, hogy a tulajdonos jogutódaként a társaság (az eljáró bíróság szóhasználata szerinti) üzletrészét megörökölje, és felette rendelkezzék, döntsön arról, hogy a társaság tovább müködjék, avagy a társaság megszünjék. Ezért a cégeljárás mindaddig félbeszakad, amíg az egyedüli tag örököse új ügyvezető választásával a félbeszakadást előidéző okot megszünteti. Az érveléssel kapcsolatban természetesen megjegyzendő az, hogy a társaság még nem jött létre, így az üzletrész örökléséről, valamint a társaság további

\footnotetext{
${ }^{276}$ Papp 2011b. 27.

${ }^{277}$ BH 1993. 761.
} 
müködéséröl, végső soron megszünéséröl, miután nem utalt arra a jogeset, hogy lett volna előtársaság, nem is lehet beszélni.

\subsubsection{A társaságok müködési szakasza}

A társaságok következő létszakasza a cégjegyzékbe bejegyzett, müködő társaságok egzisztálása, gazdasági életben folytatott tevékenységük ideje. Ez a szakasz a tagsági jogviszony megszűnésének szempontjából szoros összefüggésben van magának a gazdasági társaságnak a megszünésével, miután a tagság megszünése együtt járhat magának a társaságnak a megszünésével, célszerü ezeket együtt ismertetni, bár ezek mind időben, mind alkalmazandó szabályok tekintetében eltérő létszakaszok.

\subsubsection{Közkereseti társaság}

A közkereseti társaságok törvényes müködéséhez legalább kettő tag szükséges. A társaság jogutód nélküli megszünését eredményezi az, ha a társaság létszáma egy före csökken, (így pl. a kéttagú kkt. egyik tagja elhalálozik) és 6 hónapon belül nem jelentenek be újabb tagot. ${ }^{278} 6$ hónapon át függő jogi helyzet van: ha ezen idő alatt új tagot jelentenek be a cégbíróságnál, akkor a kkt. tovább müködhet, ha nem, akkor a határidő letelte után meg fog szünni. ${ }^{279}$ Törvényességi felügyeleti eljárás eredményeként a cégbíróság csupán megállapítja a megszünés tényét. Ez alatt a jogvesztő határidő alatt kell találni olyan személyt, aki a társaság tagjává válik - hogy ez által elkerüljék a társaság jogutód nélküli megszünését - gondoskodni kell arról, hogy legalább még egy személy tagsági jogviszonyt létesítsen, így a cég törvényes müködése (a legalább két tag, mint jellegadó fogalmi elem) helyreállhat. Észre kell azonban venni azt, hogy 6 hónap alatt nem gyakran kerül sor a hagyatéki eljárás lefolytatására, illetve annak következményeként a hagyatékátadó végzés jogeröre emelkedésére, pedig csak ezután lehet minden kétséget kizáróan megállapítani az elhunyt tag örökösének pontos kilétét (hiába ipso iure, az örökhagyó halálával következik be az öröklés). Közismert tény, hogy a hagyatéki eljárások még a legegyszerübb esetben (hatnál) is több hónapig eltarthatnak, ${ }^{280}$ mindemellett nem elhanyagolandó, hogy nem csupán törvényes, hanem végintézkedés útján történő

\footnotetext{
${ }^{278}$ Gt. 105. § (1) bek., Ptk. 3:152. § (1) bek.

${ }^{279}$ Papp 2011b. 388., KGD 2003. 3.

${ }^{280}$ Harsányi - Ujváriné - Miskolczi Bodnár 227.
} 
öröklésről is szó lehet, külföldön lévő örökös esetén különösen kézbesítési nehézségek adódhatnak, az örökösök között öröklési vita támadhat, vagy törvényes képviselöjével érdekellentétben lévő kiskorú örökös képviseletét kell rendezni a hagyatéki eljárás során. $^{281}$

A megmaradt tagnak kötelessége változásbejegyzési eljárás keretében bejelenteni az egy före csökkenés tényét, amelynek tartalmaznia kell az elhalt tag törlésére irányuló kérelmet is. A mindennapi életben meghonosodott gyakorlat az alábbi: $^{282}$ ha valószínűsíthető az örökös személye (mert például ő az örökhagyó gyermeke), akkor jelentkezik a társaságban maradt egyetlen tagnál, és megegyezik vele az elhalt vagyoni illetőségének átvételéről. Ha a jogerős hagyatékátadó végzés őt igazolja örökösként, a hagyaték az övé lesz, a tagsága nem kérdőjelezhető meg. Eddig az időpontig a megmaradt tagnak, akit egyébként az új tag belépéséig a társaság üzletvezetésére és képviseletére jogosultnak kell tekinteni akkor is, ha korábban nem minősült annak, ${ }^{283}$ kérelmeznie kell a cégbíróságnál, hogy függessze fel az esetlegesen megindult törvényességi felügyeleti eljárást. Ekkor hivatkozhat arra a megmaradt tag, hogy annak érdekében cselekedett, hogy a cég - az egyébként rajta kívül eső ok miatt bekövetkezett, de jogszabályba ütköző - müködése megfeleljen a jogszabályi elöírásoknak. Jelen esetben a hagyatéki eljárás vége, annak eredménye feltételként funkcionál. Felfüggesztő feltétel lesz akkor, ha az örökösi minőségben belépett tag kapta meg a hagyatékot, így beléphetett a társaságba e jogcímen, a fent említett (az akkor még „leendö örökös”, mivel az ipso iure öröklési rendszer alapján már az örökhagyó halálával azzá vált, de még közhitelesen nem és a társaságban bennmaradt tag között) megegyezés hatálya beáll. Bontó feltételként funkcionál a kitétel, ha nem ő lesz az örökös. Ebben az esetben a megegyezés hatálya megszűnik, a valódi örökössel el kell számolni az örökhagyó halálkori állapotának megfelelően, az immáron tényleges örökössel kell megegyeznie a közkereseti társaságnak, ha a tagjai között szeretné tudni az örököst, implicite újra kell egyezkedni. Ezzel a két megoldással a 6 hónapos jogvesztő határidőt túl lehet lépni, a társaság megszüntetésére ebböl az okból nem kerül sor, ugyanis e határidő alatt volt legalább kettő tag a társaságban. Az örökössel való megállapodásnak nincs határideje, de nyilván csak addig van mód ilyen megállapodás megkötésére, amíg az örökössel való elszámolás és a neki jutó vagyonhányad kiadására

\footnotetext{
281 Gál 2002. 5.; továbbá Molnos - Szabó 2015a. 9-11.

${ }^{282}$ Prof. Dr. Papp Tekla egyetemi tanár 2013. 03. 20-án tartott Társasági jog II. előadása alapján

${ }^{283}$ Gt. 105. § (2) bek., vö. Ptk. 3:152. § (2) bek.
} 
nem kerül sor. ${ }^{284}$ Ha utóbbi esetben az örökös nem kíván belépni a társaságba, meg kell vizsgálni a társaság tagjainak létszámát: amennyiben nem éri el a törvényben meghatározott kettő főt, úgy a társaságot jogutód nélkül meg kell szüntetni, viszont ha eléri, akkor a társaság törvényesen müködhet tovább.

Az ÍH 2005.31. döntvény tényállása szerint egy kétszemélyes közkereseti társaság tagjainak száma egy före csökkent a másik tag halála folytán. Az új tag bejegyzéséhez szükséges változásbejegyzési kérelmet azonban csak 8 hónappal a halálesetet követően nyújtotta be a cég, így az elkésett, a társaság megszünt. A társaság ez ellen fellebbezett, amit a Fővárosi Ítélőtábla elutasított. Megállapította: „a [régi] Ptk. 598. §-a [jelenleg a Ptk. 7:1. §] kimondja, hogy az ember halálával hagyatéka, mint egész száll át az örökösökre, a kkt. tagsági jogviszony azonban ilyen módon nem örökölhető, csak elszámolási kötelezettség áll fenn az örökössel.” Azaz az öröklés hagyományos ipso iure universalis successio jellegével ellentétben a közkereseti és a betéti társaságoknál meglévő vagyoni hozzájárulásoknál ez a jellemvonás nem figyelhető meg.

Ahogy az említésre került, ha a kéttagú közkereseti társaság ügyvezető tagja halálozik el, akkor sem marad képviselő nélkül a társaság: ${ }^{285}$ az új tag belépéséig, illetve a kényszertörlési eljárás megindításáig az egyedüli tagot akkor is a társaság üzletvezetésére és képviseletére jogosultnak kell tekinteni, ha korábban nem minősült annak, ${ }^{286}$ feltéve, hogy megfelel a vezető tisztségviselőkre vonatkozó törvényi elöírásoknak. Ez a tárgykör nem kapcsolódik szorosan az öröklési joghoz, viszont annál inkább a halálhoz, mint jogi tényhez.

A Gt. közkereseti társaság megszűnésére irányadó speciális, fentebb bemutatott rendelkezéseit alkotmányellenességre hivatkozva megtámadták az Alkotmánybíróság előtt. Az indítványozók álláspontja szerint a támadott rendelkezések a szerződési szabadság, a vállalkozáshoz való jog, valamint az örökléshez való jogot is megsértették. Sérelmezték, hogy a közkereseti társaság nem müködhet egyszemélyes társaságként, csak kényszerbeléptetéssel oldható meg az, hogy a törvényi határidő letelte elött ne szünjön meg a társaság, és ezáltal töröljék a cégjegyzékböl. A testület szerint a támadott rendelkezések nincsenek összefüggésben az indítványban foglaltakkal, ezért a megsemmisítésre irányuló indítványt elutasította, sőt egyes indítványbeli hivatkozások

\footnotetext{
${ }^{284}$ Kisfaludi - Szabó 759.

${ }^{285}$ Fézer et al. 2007. 79.

${ }^{286}$ Gt. 105 . § (2) bek., vö. Ptk. 3:152. § (2) bek.
} 
sem voltak összefüggésben az indítvány tárgyával. Bár a társaságok létrehozása a szerződési szabadság elve alapján lehetséges, ezt a szabadságot az irányadó törvények korlátozzák, de e korlátokon belül szabadon állapítják meg a társasági szerződés tartalmát. Közösségi irányelvekkel is ellentétes lenne az egyszemélyes forma, hiszen az csak a tagok korlátolt felelősségével müködő társasági formáknál lehetséges. Ráadásul a jogalkotó az átmeneti idő biztosításával kedvezményt adott a váratlan helyzetek orvoslására, mint például az egyik tag halála. Ezzel a korlátozással ésszerü követelményt támaszt a jogalkotó, egyszemélyes társaságként hosszú távon nem lehet jelen a piacon, ez felel meg a társaság törvényes müködésének és a hitelezővédelmi elveknek. Ha a jogalkotó lehetőséget ad az átmeneti müködésre, amennyiben egy fơre csökkent a tagság létszáma, úgy akkor az is diszkrecionalitási körébe tartozik, mennyi ideig engedi meg az ilyen helyzetet. Ez pedig nem sérti a szerződési szabadságot, nem is alkotmányossági kérdés. Megállapította továbbá, hogy a tagság személyhez kötődő jogviszony, az a halállal megszünik, abban öröklés nem valósulhat meg. ${ }^{287}$ Szintén a 3 hónapos határidő problémáját, illetve az 1997-es Gt. és a 2006-os Gt. közötti átmeneti időszakot érintette a BDT 2008. 1768. döntés. Ha valamely tag kiválásakor (halálakor) még nem tértek át a Gt. alkalmazására, nem alkalmazható a hathónapos jogvesztő határidő, hanem a három hónapos határidőt kellett alapul venni. Habár e vonatkozásban határidőt érintő változás nincs a Gt. és a Ptk. között, az új jogszabályra való áttérés szükségességét jól mutatja a jogesetben, habár a 6 hónapos bejelentési határidőt be tudták volna tartani, még a hagyatéki eljárás is befejeződött, nem volt elegendő az, hogy az új tag és a társaság életben maradt tagja megegyezett a határidőn belül, mivel a cégbíróság felé ezt a tényt nem jelezték.

A Ptk. nem változtatott a Gt.-beli szabályozás tartalmán, csak annak technikáját módosította. Az összes gazdasági társaságra vonatkozó általános megszűnési ok helyett a közkereseti és (így) a betéti társaságra alkalmazandó rendelkezés lett. ${ }^{288}$ A Ptk. 3:152. $\S$ (1) bekezdése vonatkozásában Boóc Ádám kiemeli, hogy a Ptk. nem tartalmaz arra nézve elöírást, hogy a hathónapos határidő kógens lenne, viszont roppant nagy jogbizonytalanságot szülne az, ha a joggyakorlat ténylegesen elfogadná a hat hónapos határidőtől eltérő határidő alkalmazását ez esetben. ${ }^{289}$ Ez a jogbizonytalanság megjelenik egyrészt a hitelezők oldalán, hiszen csak egy tagtól követelhetik tartozásuk

\footnotetext{
287 219/B/2004. AB határozat

288 Vö. Ptk. 3:152. §, Vékás 2013. 149.

${ }^{289}$ Boóc 188.
} 
kielégítését, ha a társaság vagyona nem fedezné azt, és nem biztos, hogy ennek a tagnak a vagyona elegendő lenne. Másrészt olyan társaság egzisztál, ami nem felel meg a törvényi követelményeknek, azaz a cégbíróságnak el kellene járni törvényességi felügyeleti eljárás keretében a Ctv. 74. § (1) bekezdésének b) és d) pontja alapján, ha még a társaság nem szűnt meg, és nem léptettek be új tagot. ${ }^{290} \mathrm{Ha}$ a meghozott intézkedések nem jártak eredménnyel, úgy a cégbíróság a céget megszüntnek nyilvánítja, emiatt elrendeli a kényszertörlési eljárás megindítását. ${ }^{291}$ Meglátásunk szerint a hathónapos határidőtől nem lehet eltérni a társasági szerződésben, mert egyrészt nem a Ptk. 3:4. § (2) bekezdése alá tartozó, a törvénytől eltérő szabályozást engedő jogviszonyok alá vonható tárgykör, mert a jogvesztő határidő leteltével a társaság megszűnik, elveszti jogalanyiságát, a cégjegyzékből törölni kell, másrészt a törvény maga mondja, hogy az jogvesztő jellegü határidő, és olyan típusjegye a közkereseti társaságoknak, amitől való eltérés esetén a típusszabadság elvébe ütközne. A határidő eltérést nem engedő voltára utal Nochta Tibor, ${ }^{292}$ ez alatt az idő alatt szükséges az, hogy a társaságban maradt tag beléptessen egy újabb tagot, ellenkező esetben a társaság meg fog szünni a törvény erejénél fogva.

Ha már a törvény erejénél fogva megszünt a társaság, ahogy az a vonatkozó, már tárgyalt eseti döntésekből is kitünik, a cégbíróságok a benyújtott változás-bejegyzési kérelmeknek, amelyekből az eljáró bíróság számára is nyilvánvalóvá vált valamely tag halála, részben tettek eleget: ${ }^{293}$ a meghalt tag tagsági jogviszonyának törlésére vonatkozó kérelmet teljesíteni kell. Ez utóbbi megállapítás nemcsak a közkereseti, hanem a többi gazdasági társaságra is igaz.

A bírósági jogalkalmazás alapján leszürhető tanulság az, hogy a társaság megszünésére irányadó jogvesztő határidőt a tag halála esetén célszerü lenne a teljes, vagy adott hagyatéki eljárástól (az örökösök között felmerülő öröklési jogvitától) függően az ideiglenes hatályú hagyatékátadástól ${ }^{294}$ számítani. Gál Judit is azon a véleményen van, miszerint a jogvesztő határidő az öröklés jogerős deklarálásától számítódjon. ${ }^{295}$ Ezt a javaslatot érdemes külön, kivételként megfogalmazni a 3:152. § rendelkezéseihez képest, ilyen szabály nélkül hiába javasolja közjegyző a társaság

\footnotetext{
${ }^{290}$ Molnos - Szabó 2015b. 10.

${ }^{291}$ Ctv. 116 . § (1) bek. a) pont

${ }^{292}$ Nochta 2014a. 570.

${ }^{293}$ Molnos - Szabó 2015b. 10.

${ }^{294}$ Vö. Hetv. 79-89. §, ezzel az állásponttal egyezően Molnos - Szabó 2015a. 9-11.

295 Gál 2002. 6.
} 
számára, várják meg a hagyatéki eljárás lezajlását, ha túlnyúlik a törvényi határidőn, úgy a társaság megszünik. ${ }^{296}$

A jogirodalomban megjelent az az álláspont is, ami szerint a Hetv. 32. § szerinti ügygondnok kirendelése nem oldja meg a törvény által jogvesztő határidőként jelzett problémát, mivel az ügygondnok nem tagként lép be. ${ }^{297}$ Meglátásom szerint azonban megoldhatja: nyilvánvalóan az örökösök érdekeivel lenne ellentétes, ha a társaság jogutód nélkül megszünne, főleg ha az nyereségesen müködik, így az ügygondnok részt vehet olyan határozatok meghozatalában, amelyek a megszünés ellen hatnának. Az ügygondnok valóban nem válik taggá, de a törvény megfogalmazása szerint a tagsági jogok gyakorlására rendelik ki, erre a biztosítási intézkedésre pedig amiatt kerülhet sor, hogy a társaság vagyonát megóvják. ${ }^{298}$ E törvényhely alapján tehet ilyen irányú jognyilatkozatot.

Az örökös társaságba történő belépésének feltételeit szabályozhatják szindikátusi szerződésben, ${ }^{299}$ de be nem lépés esetére az elszámolás körülményeit is tartalmazhatja, ${ }^{300}$ később maga az örökös is a szerződés részesévé válhat. ${ }^{301}$ A szerződés alkalmazásával a tagok hatékonyan fel tudnak készülni a társasági pozíciójuknak elhalálozásuk esetére történő változásával, amennyiben az örökhagyó pedig tájékoztatja (vélhető) leendő örököseit, úgy ők is tisztában lehetnek jogelődjük hagyatékának ilyen módon történő alakulásával. Ilyen megállapodás révén egy szerződésmintával alapított gazdasági társaság tagjai is megfelelően rendelkezhetnek valamelyikük halálának társaságra gyakorolt jogkövetkezményeiről, egyúttal jogbiztonságot és kiszámíthatóságot is nyújt a tagoknak, amennyiben eltekintünk a szerződés módosításának, illetve megszüntetésének lehetőségétől.

Kérdésként vethető fel a Ptk. 3:152. §-ban írt jogkövetkezmény alkalmazásának lehetősége is, nevezetesen az, hogy valóban meg kell-e szüntetni a társaságot abban az esetben, ha a tagsági jogviszony megszünése következtében a kkt. tagjainak száma egyre csökken, illetve bt esetén nincs a két eltérő tagi pozícióban legalább egy személy. A kkt, illetve a beltag esetén a kérdés akkor még különösebb relevanciával bír, amennyiben a társaság vagyona nem fedezi a tartozásokat, és azok kielégítéséhez szükséges a korlátlan tagi felelősséggel tartozó tagok saját vagyona is (pl. kkt. esetén az

\footnotetext{
${ }^{296}$ Barta 2017. 87.

${ }^{297}$ Molnos - Szabó 2015a. 9-11.

${ }^{298}$ Hetv. 32. § (2) bek.

${ }^{299}$ Papp 2015. 228.

${ }^{300}$ Papp 2015. 228.; Kúria Gfv. VII. 30.186/2013/6.

${ }^{301}$ Papp 2015. 226.
} 
egyetlen életben maradt tag vagyona nem képes fedezni a tartozásokat). Enélkül ugyanis a másik tag teljesítőképességében (teljes mértékben, a gazdasági realitásoknak megfelelően) joggal bízó hitelezők érdekei csorbát szenvedhetnek, de a jogutód nélküli megszüntetés ezeket a hiányosságokat nem képes megszüntetni, csak annyiban orvosolni, hogy ilyen társaság újabb kötelezettségeket - a jogalanyiságának elvesztése folytán - nem képes vállalni, ami a már hitelezői pozícióban lévők számára nem képes kielégítést nyújtani. De lege ferenda megvalósítható, mintegy a kkt.-k alóli speciális kivételként, miszerint ha egyetlen kültagja volt a betéti társaságnak, és ennek halála folytán ez a jogi pozíció kiüresedik, mégis egynél több beltag marad, akkor automatikusan közkereseti társasággá alakul a betéti társaság. Ennek az alábbiakban láthatjuk megalapozottságát: a jogtörténeti előzményként említett Kt. 125. §-ának (2) bekezdése szerint, ha több beltag volt egy betéti társaságban, akkor a társaságot közkereseti társaságnak is kellett tekinteni, megfelelően alkalmazni kellett e vonatkozásban az utóbbi társaságra irányadó szabályokat. Ez alapvetően a mai társasági jogi szabályozásra is igaz: a beltagok (miután jelen esetben többen vannak) egyetemlegesen, mögöttesen, korlátlanul felelnek a társaság tartozásaiért, ugyanúgy, mint a közkereseti társaság tagjai. Ez azt jelenti, hogy a hitelezők elsősorban nem a kültag által teljesített vagyoni hozzájárulásban, illetve nem feltétlenül a társaság vagyonában bízva kötnek szerződést a betéti társasággal. Tehát egyfajta közkereseti társaság áll fenn a betéti társaság több beltagja között akkor is, ha ma ezt a törvény explicite nem is jelenti ki. Ha azt a megoldást választjuk, miszerint a tagsági jogviszony megszünésénél fogva nem marad kültag egy betéti társaságban, de továbbra is lesznek beltagok, akkor a hathónapos jogvesztő határidő leteltével, ha nem jelentettek be új tagot a kültagi pozícióra, vagy ők nem jelentették be közkereseti társaságként való folytatást, akkor ex lege átalakul a betéti társaság közkereseti társasággá. Így a betéti társaság, miután legalább két tagja lesz, megmaradhat annak ellenére, hogy a társaság formája megváltozik. A megoldás lehetséges folytatása az, hogy nem kell automatikusan módosítani a társasági szerződést, hanem azt csak akkor kell, ha egyéb okból annak módosítására van szükség. Ezáltal olyan jogi helyzetet lehet teremteni, mint amilyen a Ptk. hatályba lépésével is előállt, az átmeneti idő lejártáig akkor kellett a Ptk.-hoz igazítani annak a rendelkezéseit, ha annak módosítására a társaság egyébként is sort akart keríteni. Ezt a módosítást pedig a kkt és bt társasági szerződésének egymás irányába mutató Ptk. 3:153. § szerinti egyszerüsített átalakulás segítségével, kisebb adminisztrációs eljárással meg lehet valósítani. 
Meglátásom szerint helyes az a jogalkotói álláspont, miszerint a közkereseti társaságok valóban csak rövid, átmeneti időre lehessenek egyszemélyes társaságok, ugyanakkor ezt az ismérvet haladéktalanul fel kell tüntetni a cégjegyzékben is a közhitelesség érdekében és azért, hogy a cégjegyzékbe betekintő személyek megismerhessék a társaság valóságnak megfelelő állapotát.

Lehetőség van arra, hogy a társasági szerződésben a tagok olyan kikötést tegyenek, miszerint bármelyik tag halálával, illetve jogutód nélküli megszünésével a társaságot végelszámolás mellett - természetesen a hitelezői követelések kielégítésére elegendő vagyon esetén - megszüntetik, ez a személyegyesítő jelleget egyértelműen erösíti. $^{302}$

A jogutód nélküli megszünést előidéző ok bekövetkezése esetén, mint amilyen ez a Ptk.-beli ok is, amennyiben nincs helye végelszámolási eljárás lefolytatásának, kényszertörlési eljárást kell lefolytatni. ${ }^{303}$ A kényszertörlési eljárásnak e ponton kívül nincs olyan speciális vonása, amely alapján az eljárás további ismertetése indokolt volna.

\subsection{Az osztrák szabályozásról}

Az osztrák jogban az UGB 131. § 4. pontja alapján bármely tag halála megszünteti a társaságot, mert a törvény azt feltételezi, hogy a személyében felelős tag halálával már nem áll fenn a társaság továbbműködtetésének érdeke. A 9.3. pontban családi vállalkozásoknál ez éppen ellenkezőleg igaz, és általános jelleggel ezért teszi lehetővé a törvény, hogy automatikusan ne szünjön meg a társaság, hanem azt fenn lehessen tartani. ${ }^{304}$

Ahhoz, hogy ne szünjön meg automatikusan a társaság, a társasági szerződésnek a törvénytől eltérő szabályozást kell tartalmaznia, de nem kell az örököst megneveznie, (hiszen azt nem lehet pontosan tudni) csak magát az öröklést kell lehetővé tennie. Jellemző a családi vállalkozásokra (bővebben még a 7.3. pontban) jogszabályi felhatalmazás alapján a fó szabálytól való eltérés, ${ }^{305}$ ezzel ugyanis pont azt a folytonosságot, amire törekednek, és egyúttal a családi vállalkozások jellegadó ismérve, törné meg bármely, a társaságban résztvevő családtag halála. E törvényi felhatalmazás

\footnotetext{
${ }^{302}$ Papp 2010b. 280.

${ }^{303}$ Ctv. 116. $\S$ (1) bek. d) pont, Barta 2017. 87-88.

${ }^{304}$ Kalss - Probst 661.

${ }^{305}$ Kalss - Probst 212.
} 
hiányában ügyelni kellene az élök közötti részesedés-átruházásra, de azon kívül a halál kiszámíthatatlan bekövetkezése mindig a társaság létét fenyegetné. A társasági szerződés nemcsak ezt a lehetőséget, hanem olyan rendelkezést, ún. „belépési klauzulát" is magában foglalhat, amellyel harmadik személy az örökhagyó helyébe léphet, ebben az esetben egyértelműen a létesítő okirat felhatalmazása, valamint az élők közötti jogügylet alapján válhat taggá. ${ }^{306}$ Mindezeken túl az életben maradt tagok maguk is elhatározhatják a társasági tevékenység folytatását. ${ }^{307}$

Minderre tekintettel a személyegyesítő társaságok (mind a közkereseti társaság, mind a betéti társaság) magas fokú szerződési szabadsága a tagok számára megfelelő szabályok felvételét teszi lehetővé. Ezek nevesítve: 1. folytatási klauzula, 2. utódlási klauzula, 3. minősített (kvalifikált) utódlási klauzula, 4. belépési klauzula. ${ }^{308}$

1. A folytatási klauzula, ahogy arra a neve is utal, arra az esetre vonatkozik, amikor valamely tag halála esetén a többi tag egymással egyszerúen folytatni fogja a társaság tevékenységét. Az örökhagyó tag örökösei a társaságba való belépésre sem nem jogosultak, sem nem kötelezettek, a hagyatékban megváltási igényként fog jelentkezni a társasági részesedés. Az ilyen klauzulával egyértelműen el tudják kerülni a tagok azt, hogy számukra nem kívánt vagy éppen arra alkalmatlan személy válhasson taggá. Az örökösnek járó társasági részesedés helyébe lépő megváltási igénnyel kapcsolatban azonban fennáll a tőkecsökkenés veszélye. A megváltási igény kiszámolására az UGB 137. §-a irányadó, ami szerint először ki kell számolni a vállalkozás értékét, majd ezt kell az adott tag részesedésére lebontani. ${ }^{309}$ Az OG-tag halála miatti kiválásának esetére járó megváltási igényt a társasági szerződésben nemcsak korlátozni lehet, hanem azt teljesen ki is lehet zárni. Egy ilyen szerződésbeli rendelkezés megengedett, az örökösök érdekei társasági jogi szempontból, a társaság müködése szempontjából nem játszanak szerepet. A megváltási igény kizárását elfogadhatónak tartja a joggyakorlat. ${ }^{310}$

2. Utódlási klauzula: az utódlási klauzula olyan társasági szerződésbeli rendelkezés, amely esetén a társaság nem szünik meg automatikusan, hanem az életben maradt tagok az örökösökkel folytatják a társasági tevékenységet. Ezzel a megszünésre vonatkozó rendelkezés háttérbe szorul, és a társasági részesedés megváltása iránti igény

\footnotetext{
${ }^{306}$ Welser 451.

${ }^{307}$ UGB 141. § (1) bek

${ }^{308}$ Kalss - Probst 661.

${ }^{309}$ Kalss - Probst 662.

${ }^{310}$ OGH 1 Ob 19/50; OGH 2 Ob 547/49; OGH 8 Ob 644/94 GesRZ 1993,38. idézi: Kalss - Probst 662.
} 
így eltünik, mivel beléphetett a társaságba az örökös. Egyszerübb esetben az ilyen klauzulák minden, tehát a nem kívánt és a társaság müködésében való részvételre alkalmatlan örökös is belép a társaságba, ugyanis az egyetlen feltétel az örökösi jogállás. ${ }^{311} \mathrm{Az}$ ilyen joghatás elleni védekezési mechanizmusnak számít a társasági tagsági jogviszonyuk felmondásával kapcsolatban az, ha az életben maradt tagok fenntartják maguknak azt a jogot, hogy bizonyos határidőn belül vagy feltétel bekövetkezése esetén felmondják a tagságukat. ${ }^{312}$ Érdekes lehetőség az ilyen esetekre képviseleti klauzulát is a társasági szerződésbe iktatni, amivel több örökös képviseletét egy közös képviselő látja el. ${ }^{313}$

3. Minősitett (kvalifikált) utódlási klauzula: a minősített (kvalifikált) utódlási klauzula a személyegyesítő társaságokra jellemző társasági szerződésbeli rendelkezés, amely alapján csak a szerződésben támasztott követelményeknek megfelelő személy válhat a társaság tagjává, ez lehet konkrétan megnevezett személy, illetve más, bizonyos feltételeknek (képzettségi követelmény, legyen a társaság munkavállalója, stb.) eleget tevő személy. Ezzel a társaság tagjai akaratának megfelelő személy válhat taggá, aki mindenféleképpen az örökös helyére kerül. Egy ilyen társasági szerződésbeli rendelkezés megléte esetén azoknak az örökösöknek a számára, akik nem váltak a társaság tagjává, megváltási igény nyílik meg. ${ }^{314}$

4. Belépési klauzula: a belépési klauzulával egy - az örökösök személyétől független - harmadik személynek lehetősége nyílik a társaságba való belépésre, aki az örökhagyó haláláig még nem volt tag. Az ilyen tartalmú rendelkezés a társasági szerződésben harmadik személy javára szóló kikötésnek minősül. A szerződésben meghatározott harmadik személy javára ez erős jogosultságot jelent, mivel nem kell figyelembe venni az öröklést a jogutód személyének eldöntésekor, de a megjelölt harmadik személy dönthet úgy is, hogy nem kíván a társaság tagjává válni - mert például a klauzula társasági szerződésbe való iktatásakor fennálló állapothoz képest romlott a társaság pénzügyi helyzete, reputációja, stb. - ekkor ezt a társasági szerződésbeli utódlási klauzulát meghiúsultnak kell tekinteni. ${ }^{315}$

Álláspontom szerint az egyes klauzulák a magyar jogban eltérő elbírálás alá esnek. A folytatási klauzula szerepelhet a társasági szerződésben, ezzel ugyanis eleve

\footnotetext{
${ }^{311}$ Kalss - Probst 663.

${ }^{312}$ Kalss - Probst 663.

${ }^{313}$ Kalss - Probst 664.

${ }^{314}$ Kalss - Probst 664.

${ }^{315}$ Kalss - Probst 665.
} 
kizárják az életben maradt tagok annak lehetőségét, hogy az örökösök ilyen minőségükben a társaságba beléphessenek. Ettől természetesen megegyezhetnek a belépésről, csak nem, mint az elhunyt személy jogutódja, azaz neki is kell mindenféleképpen vagyoni hozzájárulást teljesítenie. Az utódlási klauzula megfeleltethető annak, amikor az örökösök és a tagok megegyeztek az örökösök belépéséről. A minősített utódlási és a belépési klauzula szintén azt a helyzetet teremti meg, amikor nem sikerült a tagoknak és az örökösöknek megegyezniük, tehát nem válhattak a társaság tagjává, hanem hozzájuk képest más személy lehetett tag. Ez az állapot megfeleltethető a megváltási igény keletkezésének. ${ }^{316}$

\subsubsection{Betéti társaság}

A betéti társaságra eltérő rendelkezés hiányában a közkereseti társaság szabályait kell alkalmazni. ${ }^{317}$ Azaz a fentebb írtak a betéti társaságnál is irányadóak, a különbség a két eltérö állású tag miatt jelentkezik, a betéti társaságok különösebb jogkövetkezmény nélkül müködnek mindaddig, amíg legalább egy beltag és egy kültag van. Minimális eltérésnek minősíthető a szabály megfogalmazása, amely szabály szerint a jogi személy jogutód nélküli megszünésének általános esetein túl a betéti társaság jogutód nélkül megszünik abban az esetben is, ha valamennyi beltag vagy valamennyi kültag tagsági jogviszonya megszünik, és az ettől számított hat hónapos jogvesztő határidőn belül a társaság nem jelenti be a nyilvántartó cégbíróságnak, hogy a társasági szerződés megfelelő módosításával helyreállította a betéti társaságként való müködés feltételeit, vagy azt, hogy a betéti társaságot közkereseti társasággá alakította át. ${ }^{318}$

A betéti társaság egyetlen beltagjának halála akkor eredményezi a társaság megszünését, ha valóban beltag nélkül marad. ${ }^{319}$ A döntés alapjául szolgáló eset elbírálásakor ugyan még az 1988. évi VI. tv. volt alkalmazandó, de e tekintetben a döntés, valamint annak az alapjául szolgáló szabályozás ma is figyelembe vehető: „Megszünik a társaság, ha a társaságból valamennyi beltag kiválik." ${ }^{320}$ Kiválás alatt nem csupán a szerződéses ügylettel történő kiválást kellett érteni, hanem minden olyan jogi tényt, így a halált is, amelynek folytán a társaság tagjaiban változás áll be, konkrétabban a tag megválik a társaságtól, ahogy az a jogtörténeti példában (2.6.2.) is

\footnotetext{
${ }^{316}$ Egyes kikötésekkel kapcsolatban lásd még Barta 2016a. 12-13.

${ }^{317}$ Gt. 108. § (3) bek., Ptk. 3:155. §

${ }^{318}$ Ptk. 3:158. $\S(1)$ bek.

${ }^{319}$ KGD 1998. 106.

${ }^{320}$ 1988. évi VI. tv. 102. § (1) bek.
} 
bemutatásra került. A jogeset szerint az egyetlen beltag halálának napján a megmaradt kültag egy harmadik személlyel a társasági szerződés módosítására irányuló okiratot írt alá, amely alapján a korábbi kültag beltaggá vált, míg a harmadik személy lett az új kültag. A benyújtott változásbejegyzési kérelmet a cégbíróság elutasította, indokolása szerint a beltag halálával megszünt a társaság. A Legfelsőbb Bíróság a végzést hatályon kívül helyezte; megállapította, hogy csak akkor szünik meg a társaság, ha valóban beltag nélkül marad, a társaság megszünése nem következik be a beltag halálával ipso iure, $^{321}$ ez az értelmezés állhatott a jogalkotók akaratához is inkább közelebb, amiért lehetőséget adott az átmeneti időre.

Az ÍH 2007. 82. I. pontja absztrahálja a már törvényi szinten megfogalmazott tételt: „,a kéttagú betéti társaságnál bármelyik tagnak a tartós - törvényi határidőt meghaladó - hiánya a társaság megszünését eredményezi.” Az eset szerint a kültag halálát követő 8 . hónapban nyújtottak be változás-bejegyzési kérelmet a korábbi kültag törlése, és az új kültag bejegyzése iránt (a hagyatékátadó végzés jogerejének beállta után). A cégbíróság a kérelemnek részben adott helyt, az elhunyt kültagot törölte a cégjegyzékből, a kérelmet ezt meghaladó részben elutasította, egyúttal megállapította a társaság megszűnését 2006. május 5-i időponttal, a kültag elhunytától számított (az ekkor hatályos szabályozásnak megfelelő) 3 hónappal később, miután a cégbírósághoz a törvényi határidőn belül nem érkezett be újabb tag bejegyzési iránti kérelem. ${ }^{322} \mathrm{~A}$ Fővárosi Ítélőtábla megállapította, hogy a benyújtott fellebbezés nem alapos, az első fokon eljárt cégbíróság helyesen járt el. Igazolásra sem volt a társaságnak lehetősége, miután a 3 hónapos határidő anyagi jogi, jogvesztő jellegü, az ítélőtábla indokolásában hivatkozik is az ÍH 2005. 32. döntés megállapításaira, amely már a kifejtetteket taglalja.

Ebben a döntésben a jogvesztő jelleget akként ragadta meg a jogalkalmazó, hogy az 1997. évi CXLIV. tv. (a döntés jogszabályi hátterét nyújtó, második gazdasági társaságokról szóló törvény) anyagi jogi jogszabályokat tartalmaz, nem pedig eljárási jellegü törvény, így az abban megfogalmazott határidők is anyagi jogi, azaz jogvesztő jellegüek, ${ }^{323}$ igazolásnak éppen ezért nincs helye. Véleményem szerint a jelenleg 6 hónapos határidő további felemelése nem lenne célravezető, nagy jogbizonytalanságot eredményezhet a közkereseti társaságnál írt indokokra figyelemmel, de az ezt megelőző

\footnotetext{
${ }^{321}$ KGD 1998. 185., amelyben az előbb hivatkozott döntés jelent meg még egyszer.

${ }^{322}$ Az 1988. évi VI. tv. és az 1997. évi CXLIV. tv. 3 hónapos határidőt szabott az utolsó tag kiválásától számítva, a Gt. 110. §, valamint a Ptk. 3:152. § 6 hónapot ad.

${ }^{323}$ Ugyanerre az eredményre jutottak az eljáró bíróságok a LB Cgf. II. 31.146/2002/2., LB Gfv. 31.678/2002/2. és a BDT 2005. 1127. ügyekben.
} 
3 hónap kevés volt annak ellenére, hogy az nem volt alkotmánysértő. Ez a törvény még nem rendelkezett arról, hogy a határidő jogvesztő lenne, amit mind a 2006. évi Gt., mind a Ptk. tartalmaz, de e szemléletmódnak megfelelően döntött az eljáró bíróság az 1997. évi törvény kapcsán. ${ }^{324}$ Ugyan a jogvesztés súlyos jogkövetkezménye általában akkor következik be, ha a jogszabály kifejezetten kimondja a határidőröl annak jogvesztő jellegét, ennek hiányában is lehet azonban jogvesztő, ha a határidővel kapcsolatos rendelkezésekből ez következik. ${ }^{325}$ A társaságok megszűnése, mint jogkövetkezmény a bírósági eljárástól függetlenül bekövetkezik, annak megállapításához nem kell külön eljárást lefolytatni, nincs ellenérdekü fél, a határidő elteltét hivatalból kell a cégbíróságnak észlelnie. ${ }^{326}$

Egy másik döntés alapján, ha a kéttagú betéti társaság kültagja a társaságból kiválik, az új kültag belépésének bejelentésére nem az általános 30 napos határidő az irányadó. Az új kültag belépését a korábbi kültag kiválásától számított három (a 2006. évi Gt. és a Ptk. szerint hat) hónapon belül kell a cégbíróságnak bejelenteni. E határidő elmulasztása esetén a társaság a törvény erejénél fogva megszünik akkor is, ha az új kültag a társaságba a határidőn belül belépett. ${ }^{327}$ A Ctv. 34 . § (1) bekezdése szerint 30 nap áll a gazdasági társaság rendelkezésére a változásbejegyzési kérelem előterjesztésére a változás bejegyzésétől számítva, de a Ptk. ettől eltér e körben, mert a jogalkotó lehetőséget adott magának az eltérő szabályozás lehetőségére.

A közkereseti társaságokhoz hasonlóan a betéti társaságok esetében sem változtatta meg a Ptk. a betéti társaságokra vonatkozó, Gt.-ben foglalt szabályokat. ${ }^{328}$

Ha a társaság nem jár el a törvénynek megfelelöen, ezért megszünik, törvényességi felügyeleti eljárásban kell a bíróságnak döntenie. Ugyan se a speciális társasági jogi szabályok, se a Ctv. nem mondják ki, de az ÍH 2006. 128. számú eseti döntés megállapítása és a további töretlen bírói gyakorlat alapján kötelesek így eljárni. Egy, a korábbiakhoz képest frissebb eseti döntés, már a Ptk. szövegének ismeretében, is segíti az eligazodást, milyen eljárás alapján kell eljárnia a cégbíróságnak. (Azzal, hogy már az ÍH 2007. 82. döntés is foglalkozott ezzel a kérdéssel, és az abban foglaltakat figyelembe véve döntöttek a későbbi hasonló tényállású ügyekben.) A BDT 2014. 3086.

\footnotetext{
324 ÍH 2005. 125.

325 A mondat második fele ellentmond a 4/2003. PJE határozatban megfogalmazott elveknek. A Ptk. alkalmazásában a kérdés nem merül fel, figyelemmel arra, miszerint a határidő jogvesztő jellege egyértelműen meghatározásra került.

${ }^{326}$ Vö. BDT 2005. 1127.

327 ÍH 2004. 150.

${ }^{328}$ Lásd: Ptk. 3:158. §
} 
szerint, ha a cégbíróság tudomást szerzett a betéti társaság ex lege megszünését eredményező anyagi jogi tényállás megvalósulásáról, annak jogkövetkezményét törvényességi felügyeleti eljárásban kell megállapítania, mivel a megszűnés következtében szükségessé vált intézkedések megtétele nem illeszthető be a változásbejegyzési eljárás kereteibe. A megszünési ok bekövetkezése miatti törvényességi felügyeleti eljárást a cégbíróságnak hivatalból kell megindítania. Erre az eljárásra nem vonatkozik a korlátozás, amely tiltja a bejegyzési (változásbejegyzési) ügyhöz kapcsolódó hivatalbóli törvényességi felügyeleti eljárás indítását.

Az eset alapjául szolgáló tényállás az alábbiakban foglalható össze: egy betéti társaság kültagja 2008. 10. 23-án meghalt, amely nyomán indult hagyatéki eljárás során pót-hagyatékátadó végzést hozott a közjegyző. Ez a végzés 2013. 02. 06-án érkezett meg a cégbírósághoz, majd egy hónappal később változás-bejegyzési kérelmet nyújtottak be, ugyanis az egyik örökös tagsági jogviszonyt szeretett volna létesíteni, valamint a korábbi beltag az új kültaggal módosította a székhelyet, egyúttal a kérelemben töröltetni szerették volna örökhagyó tagságát. A cégbíróság végzésében felfüggesztette a változásbejegyzést a társaság megszünésének megállapítására irányuló törvényességi felügyeleti eljárás jogerős befejezéséig, amely a Gt. 110 . § (1) bekezdésében [ezzel egyezően Ptk. 3:158. § (1) bek.] foglaltakra figyelemmel indult a társaság ellen hivatalból. E §-ra figyelemmel indult eljárások során a cégbíróság feladata csupán az, hogy a törvényi rendelkezés folytán megszünt cég megszűnését megállapítsa, és az ebből eredő jogkövetkezményeket levonja. Az eljárás során figyelembe vették a BDT 2010. 2258. eseti döntést is. A döntés ugyan nem részletezi ezeket a jogkövetkezményeket, de azok nyilvánvalóak: a cég törvényi okból megszünt, ezért a cégjegyzékből azt törölni kell, székhelyét nem módosíthatja, illetve újabb tagot sem jegyeztethetnek be. Megfelelően járt volna el a társaság, ha a kültag halálát követő hat hónapon belül cselekedett volna ugyanígy, még akkor is, ha a belépő új tagról megállapítják egy peres eljárás folyamán, hogy álörökös. Ugyanakkor az ilyen helyzet problémát okoz a közhitelesség szempontjából, mert egy olyan személy vált taggá öröklés jogcímén, aki arra ilyen módon nem lett volna jogosult, mégis ő szerepel a cégjegyzékben. Ha a valódi örökös jelentkezik a társaságnál, mert ő kültaggá szeretne válni, az álörököst nem számítva az összes tagnak ebbe bele kell egyezni, mert rá is igaz az a szabály, miszerint a belépéshez szükséges a többi taggal való megegyezés. Ha a valódi örökössel sikerül megegyeznie a társaságnak a belépésről, úgy a társaságnak meg 
kell szüntetnie - közös megegyezéssel ${ }^{329}$ vagy a tag kizárásával ${ }^{330}$ - az álörökös tagsági jogviszonyát arra tekintettel, hogy annak fenntartása jogszabályba ütközik (úgy vált örökösi minőségben taggá, hogy valójában nem is volt örökös). ${ }^{331} \mathrm{Ha}$ nem lép be a társaságba a valódi örökös, mert eleve nem is kívánt taggá válni, hanem csak az elszámolási igényét kívánta érvényesíteni megfelelő elszámolásra van szükség. Ez megtörténhet úgy, hogy az álörökös és a valódi örökös számol el egymással, amely során megfelelően figyelembe kell venni a jogalap nélküli gazdagodás és jogalap nélküli birtoklás szabályait, valamint megvalósulhat akképp is, ami egyébként kevésbé célratörő, hogy a társaság visszaköveteli az álörököstől a neki kiadott vagyont, majd ezt a társaság adja oda a valódi örökösnek. Az az eset is elképzelhető, hogy az álörökös belépett a társaságba, de a valódi örökös nem akar, ekkor is megszünteti a társaság az álörökös tagsági jogviszonyát az előbbi indokkal, majd kiadja a valódi örökösnek az elszámolás alapján megállapított vagyont.

Eljárási szempontból meg kell állapítani először a cég törvényi ok miatti megszünését, és csak a határozat jogeröre emelkedése után lehet megindítani a kényszertörlési eljárást. A megszünést megállapító határozatot a törvényes képviselőnek kézbesíteni kell. ${ }^{332}$

A jellemzően személyegyesítő társaságokban fennálló részesedéssel összefüggő öröklési kérdések - a társaság megszünésének értelmezése szempontjából - még mindig aktuálisak, annak ellenére, hogy e vonatkozásban több közzétett, fentebb tárgyalt eseti döntés is született: az ÍH 2015. 154. számú határozat alapját egy bt. kültagjának halála miatt bekövetkező, a társaság megszünését megállapító végzés elleni fellebbezés adta. A Fővárosi Ítélőtábla jogerős döntésében a már kialakult helyes jogértelmezésnek megfelelően helybenhagyta az első fokon eljárt bíróság végzését, mert újabb tag bejelentésére a kültag halálát követő 6 hónapos jogvesztő határidőn túl került sor. Ebben az esetben a halál 2014. április 12. napján következett be, a hagyatékátadó végzés 2014. november 6-án emelkedett jogeröre, az örökös csak ezután járhatott el a társaság álláspontja szerint, holott a késlekedés miatt október 12-én már megszünt a társaság. A fellebbezésben hivatkozottak a korábbi érveléseken alapulnak, eszerint azért nem tudtak eljárni, mert nem volt pontosan megállapítható, ki lesz az örökös, és ő be szeretne-e lépni a társaságba.

\footnotetext{
${ }^{329}$ Ptk. 3:146. § a) pont

${ }^{330}$ Ptk. 3:107-3:108. §, Ctv. 71/A. §

${ }^{331}$ Vö. Papp 2011b. 382.

332 ÍH 2015. 78.
} 
Az újabb gyakorlatban került elő az a kérdés, miképp kell kezelni a társaság ex lege megszünése után beadott változás-bejegyzési kérelmet. Természetesen a cég továbbmüködésére vonatkozó adatai nem kerülnek a cégjegyzékbe bejegyzésre, még akkor sem, ha a cégbíróság elmulasztotta a törvénybeli ügyintézési határidőket. ${ }^{333} \mathrm{~A}$ megállapított tényállás szerint a betéti társaság az egyetlen beltagjának 2012. január 21-i halálát követően 2013. október 16-án terjesztett elő kérelmet 2013. október 1-jei hatállyal a beltag, egyben képviseletre jogosult törlésére és új beltag, egyben képviseletre jogosult bejegyzésére. Miután az elsőfokú bíróság szerint a többszöri hiánypótlásnak a cég nem teljes mértékben tett eleget, elutasította a kérelmet, az erről szóló végzést azonban napokkal később küldte meg. Az eljárás ideje alatt törvényességi felügyeleti eljárás indult kérelemre a változás-bejegyzési kérelem elutasítása érdekében annak megkésett volta miatt. A kérelmező észrevételt tett az eljárás folytatása miatt, míg a társaság eljárási hibákra tekintettel fellebbezett. A fellebbezés elbírálására jogosult ítélőtábla először rögzítette, hogy a cég 2012-ben a törvény erejénél fogva megszünt, és kényszertörlési eljárást indított a Ctv. 116. § (1) bekezdésének d) pontja alapján. Az első fokon eljáró bíróság helyesen észlelte a törvény ereje miatti megszünést, a jogkövetkezményt törvényességi felügyeleti eljárás során lehet megállapítani. Nincs arra lehetőség, hogy az anyagi jogszabályban előírt határidő elteltével a cégbíróság mellőzze az idő eltelte miatt bekövetkezett joghátrány megállapítását és a jogkövetkezmény levonását. Igazat adott a fellebbezőnek abban, hogy a cégbíróság számára előírt határidők leteltek, tiltó rendelkezés ellenére kettő hiánypótlásra felhívó végzést bocsátott ki, illetve azok tartalma nem állt összefüggésben a változásbejegyzési kérelem jogszabálysértő jellegével, illetve figyelmen kívül hagyta törvényességi felügyeleti eljárás iránti kérelmet. Mindezek ellenére a Ctv. 47. § (2) bekezdés szerinti automatikus bejegyződés nem következett be, mivel a hathónapos anyagi jogi, jogvesztő jellegű határidő elmulasztásához maga a törvény füzött jogkövetkezményt függetlenül cégbírósági intézkedéstől, vagy a társaság szándékától.

$\mathrm{Az}$ osztrák betéti társaságok vonatkozásában is érvényesül az a szabály, miszerint rájuk speciális rendelkezés hiányában a kkt. szabályait kell alkalmazni, ${ }^{334}$ éppen ezért a beltag halála ugyanolyan jogkövetkezménnyel jár a betéti társaságra nézve, mint az OG-ra az elhunyt tagjáé. A kültag halála viszont az UGB 177. §-a

\footnotetext{
333 ÍH 2016. 151.

${ }^{334}$ UGB 161. § (2) bek.
} 
alapján nem szünteti meg a társaságot, az ő részesedése örökölhető. ${ }^{335} \mathrm{~A} \S$ rendelkezése diszpozitív, az abban foglaltaktól eltérhetnek a tagok a társasági szerződésben, ${ }^{336}$ azaz akár akképp is rendelkezhetnek, hogy a kültag halála is megszünteti a társaságot.

\subsubsection{Korlátolt felelösségü társaságok és részvénytársaságok}

A korlátolt felelősségü társaságoknál nem található az általánostól eltérő megszünési ok, a korábbi szabályozásban csupán a Gt. 66. § c) pontja lehetett volna releváns, amely alapján - a Gt. eltérő rendelkezése hiányában - megszünt a társaság, ha a tagok létszáma egyre csökkent. (A Ptk. már eltérő szabályozási módot választott ebben a tekintetben is.) A kft. azonban müködhet egyszemélyes társaságként, így lehetséges, hogy egy kéttagú kft. egyik tagjának halála folytán a másik tag lesz az egyedüli örökös, aki a társaságot ilyen formában müködteti tovább.

Az egyszemélyes kft.-k vonatkozásában is az ügyvezetőtől kérheti az örökös tagként való bejegyzését. Megvalósulhat az az eset, hogy az egyetlen tag lesz az ügyvezető, akinek halálával nem maradt ügyvezetésre és képviseletre jogosult személye a társaságnak, azaz az örökös nem tudja kitől kérni a tagváltozás átvezetését. Ekkor a Hetv. 32. § (2) bekezdése alapján kirendelhető ügygondnok járhat el, aki maga ugyan nem fog ügyvezetőnek minősülni, de a törvény által biztosított jogkörbe beletartoznak azok a döntések, amelyek a tagváltozás átvezetéséhez szükségesek.

Ha egyetlen tagja lesz a társaságnak, akkor annak kihatása van a társaságra, hiszen nem többszemélyes formában egzisztál, mint azelőtt, mégis megfelel a jogszabály által támasztott követelményeknek. E vonatkozásban több variáció képzelhető el:

1) Ha ez az egy örökös már az örökhagyó halálakor tagja volt annak a korlátolt felelősségü társaságnak, amelyben üzletrészt örökölt, akkor a Gt. 121. §-ának (2) bekezdése értelmében az üzletrésze az átvett üzletrésszel megnövekedett. ${ }^{337} \mathrm{Ha}$ az üzletrész egy személy által történő öröklése következtében a korlátolt felelősségü társaság egyszemélyessé válik, akkor a korlátolt felelősségü társaság nem szünik meg, hanem a Ptk. 3:208. § értelmében az egyszemélyes korlátolt felelősségü társaságra vonatkozó szabályok alkalmazásával működik tovább, és

\footnotetext{
${ }^{335}$ Welser 451.

${ }^{336}$ Kalss - Probst 215-216.

${ }^{337}$ A hivatkozott Gt.-beli $§$ mai alkalmazását lásd 458. lábjegyzetben.
} 
törvényi rendelkezés alapján a társasági szerződést köteles alapító okiratra módosítani. ${ }^{338}$

2) Károlyi Géza is megállapította, hogy az egyszemélyes társaság üzletrésze is örökölhető. ${ }^{339}$ Ezzel megegyezően, ha a hagyaték tárgya egyszemélyes korlátolt felelősségü társaságban lévő üzletrész, és azt egy személy örökli, akkor ez a személy az örökhagyó jogait, ezek között a társaság vagyonát megszerzi, és a korlátolt felelősségü társaság ekkor is egyszemélyes társaságként müködik tovább.

3) Ha a hagyaték tárgyát több személy örökli, akkor az abban meglévő üzletrészt ezek a személyek megszerzik, azonban a közös tulajdonukba kerülő üzletrészen a tulajdonközösségük nem maradhat fenn, mert ekkor már nem beszélhetünk egyszemélyes társaságról. ${ }^{340}$ Ezért gondoskodni kell a tulajdonközösség megszüntetéséről, az üzletrész felosztásáról vagy más módról, így például ha az egyik örökös megveszi a többi tagtól az üzletrészhányadot. ${ }^{341}$ Amennyiben erre nem kerül sor, akkor már többszemélyes kft.-vé válik a társaság. ${ }^{342}$

Ausztriában sem érinti a tőkeegyesítő társaságok fennmaradását valamely tagjának halála, ugyanakkor a GmbHG 84. § (2) bekezdése alapján megengedett az olyan társasági szerződésbeli rendelkezés, ami szerint bármelyik vagy egy konkrétan megnevezett tag halála esetén megszünik a társaság. ${ }^{343}$ Ez a lehetőség a magyar jog alapján is adott, a Ptk. szabályozása ezt a lehetőséget nem zárja ki.

A részvénytársaságok a korlátolt felelősségü társaságokhoz hasonlóan müködhetnek egyszemélyes formában is, ${ }^{344}$ az ott leírtak erre a társasági formára is irányadóak. A részvénytársaságok létezését sem érinti valamely részvényes halála, a részvény forgalomképessége ${ }^{345}$ miatt nincs olyan jogi tény, ami ezt befolyásolhatná. $\mathrm{Az}$ osztrák jogban a korlátolt felelősségü társaságokhoz hasonlóan a részvénytársaságnál sem érinti a halál a társaság létezését, még annak alapítását sem. ${ }^{346}$

\footnotetext{
${ }^{338}$ Koday 9.

339 Károlyi 398.

${ }^{340}$ EBH 2003.884. I.: Egyszemélyes korlátolt felelősségű társaságnak csak egyetlen tagja lehet. A cég egyetlen üzletrésze több személy tulajdonában nem állhat. LB Cgf. VII. 32.752/1997/2., Fővárosi Ítélőtábla 10. Cgf. 45.071/2010/2., EBH 2001. 541., LB Gf. VII. 33.265/1999/5. idézi: Papp 2011b. 442.; Koday 10., Barta 2012. 24.Ezzel ellentétes álláspontot képvisel Károlyi 397.

${ }^{341}$ Koday 10.

${ }^{342}$ Vö. Anka 2014a. 71., Barta 2017. 92.

${ }^{343}$ Kalss - Probst 667.

${ }^{344}$ Ptk. 3:323. $\S$

${ }^{345}$ Ptk. 3:213. \$

${ }^{346}$ Doralt - Nowotny - Kalss 81 .
} 


\subsubsection{A gazdasági társaságok megszüntetése körében alkalmazott eljárások}

A társaság megszünéséhez vezet a felszámolási eljárás, valamint a kényszertörlési és a végelszámolási eljárás is, amelyeket nem vagy csak kisebb szegmensben érinthet a tag halála. Végelszámolási eljárás esetében mindaddig, amíg az eljárás folyamatban van, a társasági részesedés a társaságra vonatkozó speciális szabályok alapján jogutódlás tárgyává válik. ${ }^{347}$ Ugyanez lesz igaz a felszámolási és a kényszertörlési eljárásra is, még ha adott esetben a megszünéshez vezető okot - mindkét eljárásnál - az örökhagyó szolgáltatta: az eljárások alatt még az örökhagyóé a társasági részesedés, abban a társasági formának megfelelő jogutódlás bekövetkezhet. $\mathrm{Ha}$ az eljárás befejeződött és a társaságot törölték a cégjegyzékből, továbbá az örökös taggá kívánna válni, de még nem lépett be a tag (kkt és bt esetén), illetve nem került átvezetésre a tagjegyzéken és a részvénykönyvben, akkor a társaság megszünése esetére - a hitelezői igények kielégítése után - a tagokat megillető vagyonhányadra lesz jogosult, ami pedig örökölhető.

\subsubsection{A vagyonrendezési eljárás}

A vagyonrendezési eljárás ${ }^{348}$ ugyan nem a társaság egyik megszüntetési formája, de csak a társaság megszűnése után lehet lefolytatni. Az eljárás során előkerülhet olyan vagyontárgy, mely végső soron, az eljárás befejezése alapján, annak eredményeként az örökhagyót illette volna meg, azért, mert adott esetben a társasággal szemben fennálló hitelezői igényeket végelszámolási vagy kényszertörlési eljárás során teljesen kielégítették. Az előkerült vagyontárgy a tagokat illeti meg, és ha erre még az örökhagyó életében sor került volna, az minden kétség nélkül a hagyaték tárgyává vált volna. A vagyonrendezési eljárás célja nem a felszámolás vagy a végelszámolás pótlása, „meghosszabbítása”, hanem megszünt, jogalanyiságát vesztett cég, ezáltal gazdátlan vagyonának jogi sorsának rendezése, ${ }^{349}$ de az eljárás elrendelése nem jelenti a felszámolási eljárás eredményeként megszünt és a cégjegyzékből törölt cég jogképességének feléledését. ${ }^{350}$ Nem nyújt lehetőséget a további egyértelműen el nem

\footnotetext{
${ }^{347}$ Koday 11.

${ }^{348}$ Ctv. 119-124. §

${ }^{349}$ ÍH 2006. 82., ÍH 2013. 86., Bodor 7.

350 ÍH 2006.130.
} 
dönthető rendezetlenül maradt vagyoni kérdésekre, a vitás tulajdoni helyzetek rendezésére, ${ }^{351}$ azonban mindenféleképp tisztázni kell az előkerült vagyontárgy tulajdonjogát. ${ }^{352}$ Előfordulhat az az eset, hogy a társaság megszünésekor az örökhagyó még tag volt, halála a megszünést követően következett be. A később elökerült vagyontárgy örökhagyóra jutó értéke iránt a volt tagok örökösei is igényt támaszthatnak a rájuk jutó örökrész arányában, tekintettel arra, hogy ez az igény az örökhagyót is megillette volna, az igény átszállhat, és ha a társaság nem szünt volna meg, az örökhagyó pedig még ennek a müködése alatt hal meg, a társasági formától függő jogutódlás következett volna be. Ha a társaság ezután szünik meg, az örökösök tarthatnak igényt az ilyen vagyontárgyra. A Szegedi Ítélőtábla az egyik döntésében ${ }^{353}$ az előző cégeljárási törvény, az 1997. évi CXLV. törvény miniszteri indokolására hivatkozott, ami szerint a vagyonrendezési eljárás során elökerült vagyontárgy felosztásakor csak azokat a tagokat kell figyelembe venni, akik ténylegesen igényt támasztottak arra. Tekintettel arra, hogy a polgári eljárásjog egyik alapelve a kérelemre történő eljárás, illetve tekintettel a Ctv. rendelkezéseire, ha a volt tag vagy annak örököse az eljárásról szóló hirdetmény közzétételének ellenére nem kapcsolódik be az eljárásba, úgy kell tekinteni, mint aki az igényéről lemondott. ${ }^{354}$ Tehát ha az örökös kéri, ki kell adni neki a vagyontárgyat vagy az értékesítés során kapott ellenértéket a rá jutó rész erejéig. Kérelemhez kötöttség hiányában a volt tagok örököseinek felkutatása lehetetlen helyzetbe hozná a bíróságot.

\subsection{Az örökösök jogi helyzete az egyes társaságoknál}

\subsubsection{Közkereseti társaságok}

A közkereseti társaságoknál a tagok által a társaságra ruházott vagyonelemeket vagyoni hozzájárulásnak nevezzük, azaz a korlátolt felelősségű társasághoz (üzletrész) és a részvénytársasághoz (részvény) képest nincs speciális elnevezés. A tag halálakor tagsági jogviszonya megszünik, a tagsági jogokat - mint személyhez füződő jogokat, ahogy azokat az örökhagyó gyakorolhatta - az örökösök nem szerzik meg. ${ }^{355}$ A jogutódjának, annak a személynek, aki a kkt.-beli vagyoni hozzájárulás tekintetében

\footnotetext{
351 ÍH 2006. 82.

352 BDT 2016. 3553.

353 ÍH 2011. 46.

354 ÍH 2014. 127.

355 Tóth 4.
} 
örökös lesz, lehetősége van a társaságba való belépésre, de ez nem kötelezettsége. ${ }^{356}$ Egyetértek e körben Besenyei Lajossal, hiszen „teljesen fölösleges ezt kimondani, mert bárki, bármikor beléphet a társaságba, ha a tagokkal ebben megegyezett és a Gt. [Ptk.] által elöírt minimális feltételeknek megfelel." ${ }^{357}$ E gondolatmenethez hozzá kell füzni, helytállónak tartom azt, hogy bárki, bármikor beléphet a társaságba, de egyrészt ekkor a belépő tagnak nem kell külön vagyoni hozzájárulást teljesítenie (hacsak ekként nem állapodik meg a társasággal), másrészt eltérően alakulhat a felelőssége. Igaz az, „habár a magyar jog az ipso iure öröklés elvét vallja, mely szerint az öröklés megtörténik a halál beálltával, ahhoz, hogy az örökös a kkt. tagja legyen, szükséges, hogy a társaság tagjaival az örökös megegyezzen.”358 Nem az öröklés lesz a tagsági pozíció megszerzésének jogcíme, hanem a megállapodás, amit az életben maradt tagok és az örökös(ök) kötnek meg. ${ }^{359}$

A vállalkozás és társulás szabadságának, mint társasági jogi alapelvnek alanyi (nem alapíthat bárki gazdasági társaságot, illetve abban nem vehet részt tagként), tárgyi (nem alapítható bármely tevékenységre gazdasági társaság) és módbeli (nem létesíthető bárhogyan társaság) korlátai vannak, ${ }^{360}$ amely alanyi korlátok nem állhatnak fenn a belépő örökös vonatkozásában sem. Ezek a - természetes személy örökös vonatkozásában releváns - korlátok az alábbiak:

- Legalább két tag szükséges gazdasági társaság alapításához, ez alól a kft. és az rt. kivételt képez. A tagok létszámát illetően bővebben már kitértem az értekezés 4.2.1.1. pontjában a kkt., míg a bt. vonatkozásában a 4.2.1.2. fejezetben.

- Külföldiek gazdasági társaságban való részvétele nemzetközi szerződés és a magyar jogszabályok alapján lehetséges, ezek nem zárják ki azt, hogy külföldi állampolgárú örökös részesedést szerezhessen.

- Természetes személy egyidejüleg csak egy gazdasági társaságnak lehet korlátlanul felelős tagja, ${ }^{361}$ amely követelménynek teljes mértékben eleget kell tenni a közkereseti és betéti társaságok vonatkozásában, ahol ez a kérdés releváns lehet. Ha az örökös közkereseti társaságba vagy betéti társaságba beltagként kíván belépni az örökhagyó helyére, de ilyen minőségben már tag

\footnotetext{
${ }^{356}$ Gt. 103. §, Ptk. 3:149. §, Csüri 132., Barta 2017. 83.

${ }^{357}$ Besenyei 2002. 12., Besenyei 2004. 501.

${ }^{358}$ Boóc 185.

${ }^{359}$ Kisfaludi 2014b. 362.

${ }^{360}$ Papp 2011a. 124-126., Papp 2011b. 27-29.

${ }^{361}$ Ptk. 3:90. § (1) bek.
} 
egy másik betéti társaságban, úgy betéti társaságnál lehetőség nyílik arra, hogy a másik tagot túlélö kültag beltaggá váljon, így az örökös lesz a társaság kültagja, amennyiben ekképp meg tudnak egyezni. Közkereseti társaság esetén is, amennyiben ilyen helyzet állna elő, az örökös választhat, mely társaság tagja szeretne lenni, azaz belép az új társaságba, és megszünteti a tagsági jogviszonyát a korábbi társaságban, vagy tag marad ebben, és elszámol az életben maradt taggal. Ez utóbbi esetben a bennmaradt tagnak más módon kell gondoskodnia arról, hogy a törvénynek megfelelő taglétszám legyen. Ennek nem mond ellent az öröklés ipso iure mivolta, ugyanis elszámolási igényre mindenképp jogosult.

- Kiskorú személy (örökös) nem lehet társaság korlátlanul felelős tagja, azaz kkt tagja, illetve bt beltagja, ${ }^{362}$ a contrario bt kültagja, kft tagja, illetve részvényes lehet. A szabály itt sem mond ellent az öröklési jog alapelveinek, hiszen a kiskorú jogosult lesz az elszámolási igényre. A Ptk. ezzel a rendelkezéssel a kiskorú vagyoni érdekeit kívánja védeni megakadályozván azt, hogy a gyermek törvényes képviselöje indokolatlanul kockáztassa a kiskorú vagyonát. ${ }^{363}$ A kiskorú és a túlélő szülő közötti esetleges érdekellentétet akár gyámhatóság útján kell tisztázni. ${ }^{364}$

- Az egyéni vállalkozó örököse nem lehet egyidejűleg kkt tagja, illetve bt beltagja. 365,366

A halállal megszünt tagsági viszony alapján az örökhagyót megillető „társasági vagyoni részesedés" az örökhagyó hagyatékához tartozik ugyan, hiszen vagyoni természetű jogokról, kötelezettségekről van szó, de mint ahogy a tagsági jogviszonyt, a „társasági vagyoni részesedést” sem örökli az örökös. Anka Tibor ezt „szaggatott jogutódlásnak" nevezi: a hagyatékhoz tartozó tagsági részesedést az örökös nem örökli meg, hanem a halállal elszámolási igénye keletkezik, noha ilyen igénye az örökhagyónak nem volt, ugyanis neki tagsági jogviszonya állt fenn. ${ }^{367}$ Olyan jogosultsága lesz az örökhagyó halálánál fogva az örökösnek, ami jogelődjének nem volt, de olyan nem lesz, mint ami a gazdasági társaság elhunyt tagját tagsági jogviszonyánál fogva illette meg. Anka Tibornak ezt a jogi helyzetet illető elnevezése

\footnotetext{
${ }^{362}$ Uo.

${ }^{363}$ Török T. 2015. 246-247.

${ }^{364}$ BH 1998. 438.

365 2009. évi CXV. törvény 3. § (2) bek. d) pont

366 Mohai 2016b. 450.

${ }^{367}$ Anka 2006. 11., Vö. Kisfaludi 2014b. 362.
} 
megtévesztő lehet abban a vonatkozásban, hogy itt eltérő jogutódlásról van szó, mert csak a vagyoni hányadra irányulhat az igény.

A tagsági jogviszonyban történő jogutódlás ipso iure a halál tényénél fogva nem következik be, pusztán az öröklés nem lehet jogcíme a közkereseti társaságba történő belépésnek, eltérően az általános öröklési szabályoktól, így a társasági jog speciális rendelkezései folytán csak jogügyleti alappal, pontosabban a társasággal történő megegyezés alapján válhat taggá az elhunyt tag örököse, ${ }^{368}$ nem elegendő csupán így rendelkeznie a társasági szerződésnek. Ez a szabály is a kkt. erősen személyegyesítő jellegét hangsúlyozza, a tagság személyhez kötött, azzal kapcsolatban ipso iure bekövetkező jogutódlásnak nincs helye, ${ }^{369}$ szemben a többi öröklés alá eső vagyontárggyal. A törvény csupán lehetőségként szabályozza a társaságba történő belépést, erre azonban a társaság hozzájárulása nélkül nem kerülhet sor. ${ }^{370}$ Ezt a lehetőséget a törvény biztosítja az örökös számára, attól függően, hogy a megmaradt tagok és az örökös közötti bizalmi viszonyra tekintettel az előbbiek hajlandóak-e a valamennyi tag egyhangú igenléséhez kötött társasági szerződés módosítására, ami az örökös taggá válásának előfeltétele. Az egyhangú határozatra azért van szükség, mert a közkereseti társaságbeli tagváltozás esetén módosítani szükséges a társasági szerződést is, amelyhez ennél a társaságnál valamennyi tag egyhangú szavazatára szükség van. ${ }^{371}$

Az örökös társasági taggá válása sem az örökös, sem a társaság megmaradt tagjai számára nem kényszer, ez az olyan - a tagok szoros együttmüködését feltételező - cégformánál, mint a közkereseti vagy a betéti társaság, a vállalkozás szabadságának, $\mathrm{s}$ ezen belül a partnerválasztás szabadságának elvét sértené. ${ }^{372}$ Egyet lehet érteni Nochta Tiborral abban, hogy a belépéshez nem szükséges a hagyatéki eljárás jogerős befejezése, ${ }^{373}$ ezáltal elkerülhető a társaság jogutód nélküli megszűnése, ugyanakkor észre kell venni azt, egyáltalán nem biztos, hogy végül az a személy lesz az örökös, tehát álörökös az -, akivel a társaság megállapodott. Felmerülhet ez által az álörökös felelőssége a valódi örökösök irányában, már csak azért is, mert az álörökös esetben kérdéses lehet, vajon teljesített-e vagyoni hozzájárulást arra tekintettel, hogy (vélt) jogelödje már megtette azt. Amennyiben nem, a 2.2. pontban írtak a felelősség

\footnotetext{
${ }^{368}$ Vö. SZIT-H-PJ-2015-41.

${ }^{369}$ Papp 2011b. 382., Kisfaludi - Szabó 759.

${ }^{370}$ Adorján 1999. 8.

${ }^{371}$ Ptk. 3:143. § (4) bek., vö. Barta 2016a. 10.

${ }^{372}$ Fővárosi Ítélőtábla 14. Cgtf. 44.222/2013/2. határozata

${ }^{373}$ Nochta 2014b. 564.
} 
vonatkozásában teljes mértékben helytállóak, ha igen, úgy ehhez viszonyítva megfelelően el kell vele számolni.

A többi örökölhető vagyontárgyhoz képest tehát különbséget mutat a kkt.-beli vagyoni hozzájárulás, erre tekintettel a társasági szerződés az alábbi módokon rendelkezhet az örökös belépéséről:

a) ha kizárja a belépést, akkor két lehetősége marad a társaságnak: vagy nem módosítják a társasági szerződést, és továbbra sem teszik lehetővé a jogutód belépését a társaságba, vagy egyhangúlag módosítják annak megfelelően, hogy az örökös beléphessen a társaságba;

b) eleve megengedi a belépést, így egyhangúsággal hozott támogató határozat ${ }^{374}$ révén a társaság tagjává válhat az örökös;

c) amennyiben a társasági szerződés nem rendelkezik arról, hogy mi történik az elhunyt tag társaságban fennálló vagyoni hozzájárulásának rendezéséről, a fenti két lehetősége lesz a társaságnak egyhangú társasági szerződésmódosítással.

A Ptk. 3:139. § (4) bekezdése alapján a társaságba belépő tag felelőssége a belépése előtt keletkezett társasági kötelezettségekért a többi tagéval azonos. A tag helytállási kötelezettsége ebből fakadóan ex tunc, korlátlan és egyetemleges, míg jogai ex nunc hatályúak, ${ }^{375}$ azaz a gyakorlásuk a megállapodáshoz, valamint a változás bejegyzéséhez kötődik, ezzel szemben egyrészt azok a társasági vagyon által ki nem elégített tartozások is terhelik, amik még az örökhagyó életében keletkeztek, másrészt azok is, amelyek az örökhagyó halála és az ő belépése közötti időszakban keletkeztek. Ezekre egyértelműen nem lehetett ráhatása sem. A Gt. 97. § (3) bekezdése megengedte az eltérést, azaz a tagoknak lehetőségük nyílt arra, hogy az öröklés következtében belépő tag felelőssége csak a belépése után keletkezett kötelezettségek tekintetében álljon fenn, ezzel a tag felelőssége ex nunc hatályú is lehetett, ami a felelősség időbeli korlátozását jelentette. Tehát a belépő tag felelősségét a belépése előtt keletkezett társasági tartozásokért a társasági szerződésben vagy annak módosításában a hitelezőkkel szemben hatályosan ki lehetett zárni; a kkt. tagjainak egyetértése (egyhangú határozata) volt szükséges az ex tunc jellegü felelősség ex nunc jellegüvé alakításához. ${ }^{376}$

\footnotetext{
${ }^{374}$ Papp 2011b. 386.

${ }^{375}$ Papp 2011b. 380. ${ }^{376}$ Uo.
} 
A Ctv. előírásai alapján ilyen adat nem (nem volt, és jelenleg sem) jegyezhető be a cégjegyzékbe, és miután a Gt.-ben sem lehetett találni a bejegyezhetőségre utaló rendelkezést, elképzelhető volt az a jogértelmezés, mely szerint harmadik személyek irányában joghatályosan mégsem lehetett kizárni az új tagnál a többi taggal azonos felelösséget. Ezt a bizonytalanságot oldotta fel a Ptk., amikor kimondja, hogy az ilyen megállapodás harmadik személyekkel szemben nem hatályos. ${ }^{377} 2014$. március 15. után nem lehetséges az örökös, mint belépő tag felelősségének időbeli korlátozása, azaz a társaságba belépő tag a belépése előtt keletkezett társasági kötelezettségekért a többi taggal azonos módon köteles helytállni. Ettől nem lehet eltérni, mert a tagok ezzel ellentétes megállapodása harmadik személyekkel szemben nem hatályos. A törvényszöveget megvizsgálva azonban arra a következtetésre juthatunk, attól, hogy ez a megállapodás harmadik személlyel szemben nem hatályos, nem jelenti azt, hogy ne lehetne ilyeneket kötni. Ebben az esetben ugyan a hitelezőkkel szemben a társaságba tagként belépö örökös nem hivatkozhat arra, hogy a belépése előtt keletkezett tartozásokért nem áll fenn a felelössége, de a tagok egymás közötti elszámolása során ilyen tartalmú megállapodás esetén regress igénye lehet azután, hogyha ő tett eleget a hitelezői követelésnek. Meglátásom szerint ez megfelel a Ptk. 3:4. §-ában megtalálható diszpozitivitási tesztnek, mivel a hitelezők érdekei megfelelően biztosítva vannak azzal, hogy velük szemben nem zárható ki az új tag felelőssége, így akár tőle is követelhetik a tartozás teljesítését, a belső elszámolási viszonyok az ő érdekkörükön kívül maradnak, ez pedig a tagok egymás közötti viszonyához tartozó kérdés. Ezt a kérdéskört akár szindikátusi szerződésben is rendezhetik a tagok.

Az örökös lehetősége az is, hogy nem lép be a társaságba. Ebben az esetben a Gt. 103. § szerint el kellett vele számolni, akként, amint azt a társaságtól egyébként megváló taggal (ide nem értve a társasági részesedését átruházó tagot) tették. „,Az elszámolás a társaság vagyonának forgalmi értékéből a tagra jutó rész értékének megállapítását célozza. ${ }^{\text {378 }}$ Az örökös igényt tarthat a meghalt tag kilépése esetére jutó vagyoni hányadra. A kilépés időpontjának a halál idejét kell tekinteni. Az elszámolás amelynek bizonyos részletkérdéseit rendezhetik a társasági szerződésben ${ }^{379}$ - kötelező a tagsági jogviszony megszünése esetén a volt taggal, az örökössel, illetve a jogutóddal, kivéve, ha a társasági részesedés átruházására kerül sor vagy az örökös (a jogutód jogi

\footnotetext{
${ }^{377}$ Nochta 2014b. 554.

${ }^{378}$ Kisfaludi 2014b. 363.

${ }^{379}$ Barta 2017. 84.
} 
személy tag jogutóddal való megszünése esetén) belépett a társaságba. ${ }^{380} \mathrm{Ha}$ ezt a kötelezettséget a társasági szerződés kizárná, korlátozná, vagy a tagra nézve törvényben meghatározottaktól kedvezőtlenebbül állapítaná meg, akkor az a rendelkezés semmis. ${ }^{381}$ „Ez lényegében a societas leonina egyik megjelenési formájaként értékelhető."382 Az elszámolás pénzben célszerü, ugyanis a természetbeni elszámolás megnehezítheti a társaság helyzetét, mert például olyan vagyontárgy kiadását lehet követelni, ami a társaság müködéséhez szükséges. ${ }^{383}$

Tehát az elszámolás alapvetően lehetőség az örökös belépésekor, de ebben az esetben bizonyos körülmények esetén érdemes, sőt ajánlottnak tekinthető: így több örökös belépése esetén (az egyes örököstársakra eső vagyonhányad pontos megállapítása miatt), vagy ha a hagyaték tiszta értékét egyébként nem tudják megállapítani, illetve akkor is, ha az örökös az örökhagyó társaságbeli vagyoni hozzájárulásának mértékéhez képest kisebb vagy nagyobb értéken kíván belépni. ${ }^{384}$

Kkt. és bt. esetén, amennyiben az elhalt tagnak több örököse van, lehetséges, hogy közülük csak az egyik válik a társaság tagjává a többi taggal való megállapodás alapján, de kérdés tárgyát képezi az is, hogy több örökös esetén ez a lehetőség csak valamennyiüket együttesen illeti-e meg. Mindegyik örökösnél külön-külön kell azt megítélni, hogy a ráeső vagyonnal be kíván-e lépni az adott társaságba és ahhoz a társaság többi tagja hozzájárul-e. A Gt. (Ptk.) vonatkozó rendelkezései egyes számban beszélnek az örökösről, logikus azonban, hogy több örökös esetén mindegyikükre külön-külön irányadóak a törvényi rendelkezések. ${ }^{385}$

A Legfelsőbb Bíróság Gfv. II. 30.759/1999/8. sz. határozata kimondta, hogy a korabeli társasági törvény - hasonlóan a Ptk. 3:150. §-ában foglalt szabályozásához - az elszámolás módjának tisztázását a társaság és a tag megállapodására hagyja. Az elszámolásról szóló megállapodás nem tekinthető semmisnek amiatt, mert annak megkötését nem előzte meg vagyonkimutatás és közbenső mérleg felállítása. A jogszabály az elszámolásra vonatkozó megállapodás érvényességét ilyen okiratok elkészítéséhez nem köti, csupán azt mondja ki, hogy az elszámolásnak a társaság mely időpontjában fennálló vagyoni helyzetén, állapotán kell alapulnia, ami nem más, mint a

\footnotetext{
${ }^{380}$ Ptk. 3:150. $\S(1)$ bek.

${ }^{381}$ Ptk. 3: $150 . \S$

382 Boóc 173 .

${ }^{383}$ Barta 2017. 84.

${ }^{384}$ Prof. Dr. Papp Tekla egyetemi tanár 2013. 03. 20-án tartott Társasági jog II. előadása alapján; Gál 2002. 4.

385 Wellmann 7.
} 
tagsági jogviszony megszünése, azaz a tag halála. Egyet lehet érteni azzal az állásponttal, hogy szerencsés lehet egy közbenső mérleg készítése, ill. vagyonkimutatás felvétele, mivel ezek objektív, nemzetközi standardokon alapuló értékelési módszerek, melyek a társasági vagyon valós, aggálymentes és a későbbi viták lehetőségét kizárni képes értékét tudják megállapítani. ${ }^{386}$

A korábbi öröklési jogi szabályok hatálya alá eső esetekben (pontosabban a 2014. március 14-én, vagy előtte elhunyt személyek hagyatékában megtalálható társasági részesedés vonatkozásában) ${ }^{387}$ az elszámolási kötelezettség mellett szólt az a körülmény is, hogy a házastárs holtig tartó haszonélvezeti jogot kapott azokra a vagyontárgyakra, amelyeket nem ö örökölt. Ebben az esetben a leszármazó is, és a túlélő házastárs is kérhette a haszonélvezeti jog megváltását. Ha az örökössel, aki belépett a társaságba, nem számoltak el, akkor ezt a haszonélvezeti jogot nem lehetett megváltani, mert nem volt ismert a hagyaték értéke. ${ }^{388} \mathrm{Ez}$ annyiban változott, hogy a Ptk. csak a közösen lakott lakáson és az ahhoz kapcsolódó berendezési és felszerelési tárgyakon ad haszonélvezeti jogot az özvegynek, míg a hagyaték többi részéből (azaz többek között a társasági részesedésből is) egy gyermekrésznyit kap, és nem haszonélvezetet. ${ }^{389}$ Ugyanakkor ez is amellett szól, hogy az elszámolás megtörténjen a fent hivatkozott indokok alapján, egyúttal jelezzük azt is, hogy osztályos egyezségben az örökösöknek lehetőségük van arra, hogy a gyermekrész helyett az egész hagyatékra kiterjedő haszonélvezetet biztosítsanak az özvegynek, ${ }^{390}$ ezzel ugyanolyan jogi helyzetet teremtve, mint ami a régi Ptk. szerint volt.

Az sem tekinthető elhanyagolható szempontnak, hogy az örökös felelősséggel tartozik az örökhagyó tartozásaiért, ez a felelössége a hagyaték tárgyaihoz, illetve annak értékéhez igazodik. Ha a kívülálló harmadik személy, mint hagyatéki hitelező lép fel a társaságba tagként belépő örökössel szemben, meg kell tudni állapítani a hagyaték értékét, mert ez lesz az örökös felelősségének a felső határa és a társaságba tagként belépő örökös ilyen mértékig fog az örökhagyó tartozásaiért felelni. ${ }^{391}$

Az elszámolás tehát annak megállapítását jelenti, hogy a társaságtól megváló tagnak követelése van a társasággal szemben a tagsági viszony megszünésének időpontjában. Az elszámolás célja a társaság vagyonának forgalmi értékéből a tagra jutó

\footnotetext{
${ }^{386}$ Boóc 186.

${ }^{387}$ Ptké. 57. § (1) bek.

${ }^{388}$ Besenyei 2004. 502

${ }^{389}$ Ptk. 7:58. § (1) bek.

${ }^{390}$ Ptk. 7:58. § (3) bek.

${ }^{391}$ Besenyei 2004. 502-503.
} 
rész értékének megállapítása. A Ptk. indokolása is kiemeli, hogy az elszámolásnál természetesen figyelembe lehet venni a számviteli nyilvántartások adatait is, amennyiben a felek egyetértenek abban, hogy azok a valós forgalmi értékeket tükrözik. Az elszámolást minderre tekintettel úgy kell elvégezni, hogy a tagsági jogviszony megszünésének időpontjára vetítve meg kell állapítani azt, hogy a társasági vagyon mekkora forgalmi értéket képvisel, és ebből a tag részére a vagyoni hozzájárulásával arányos részt kell pénzben kifizetni. A kifizetésnek legkésőbb a tagsági jogviszony megszünésétől számított három hónapon belül meg kell történnie. ${ }^{392}$

Amennyiben az elhalt tag jogutódja nem válik a társaság tagjává, akkor a Gt. 104. § (2) bekezdése alapján a jogelőd halálának időpontjától számított ötéves jogvesztő határidőn belül az örökhagyó tartozásaiért való felelősség szabályai szerint felelt azokért a társasági tartozásokért, amelyek a halál időpontjáig keletkeztek. E § tehát visszautalt a Ptk. 679. §-ra. Több örökös esetén - az örökösök számára tekintettel - egyetemleges felelősség állapítható meg a közkereseti társaság tartozásaival kapcsolatban. A hagyatéki tartozások fedezetére egyrészt a cum viribus felelősség, másrészt a pro viribus felelősség kerül megfogalmazásra; az örökös(ök) felelőssége korlátozott arra tekintettel, hogy nem léptek be a társaságba, belépésük esetén felelősségük, a fentieknek, valamint a közkereseti társaság szabályainak megfelelően, korlátlan lesz. A cum viribus felelösségnél az örökös(ök) még a hagyaték tárgyainak birtokában vannak (,a hagyaték tárgyaival és annak hasznaival felel”). A pro viribus felelősség esetén a hagyaték tárgyai és hasznai nincsenek az örökös birtokában, annyiban az örökös öröksége erejéig egyéb vagyonával is felel. ${ }^{393}$ Ezen a szabályon a Ptk. sem változtat: ${ }^{394}$ „Más a helyzet a meghalt tag társaságba be nem lépő örökösének helytállási kötelezettségével, amely a hagyatéki tartozásokért való felelősség szabályai szerint alakul. Ez a Ptk. 7:96. § szerinti korlátozott felelősséget jelenti. A közkereseti társaság tagja csak a tagsági jogviszonya megszünéséig esedékessé vált társasági tartozásokért tartozik helytállni." 395396 A tag felelősségének különös előfeltétele az, hogy a tartozás a tagsági jogviszony megszünése, vagyis a tag cégjegyzékből történő törlése előtt

\footnotetext{
${ }^{392}$ Nochta 2014b. 565.

${ }^{393}$ Vö. Ptk. 679. §, Nochta 2011. 261.

${ }^{394}$ Ptk. 3:149-3:151. §, Boóc 173-174.

${ }^{395}$ BH 2013. 130.

${ }^{396}$ Nochta 2014b. 566.
} 
keletkezzen. ${ }^{397}$ A bekezdés lényege, hogy a hitelezők nem kerülhetnek hátrányosabb helyzetbe a tag halála miatt, már csak azért is ugyanaz a felelősség, mert lényegtelen, mi volt a hagyatéki tartozás forrása. ${ }^{398}$

„Abban az esetben, amennyiben a hagyaték tárgyát közkereseti társaságban fennálló társasági részesedés is képezi, az örökösnek a hagyaték elfogadása előtt azt is végig kell gondolnia, hogy a kkt. felelősségi rendszeréből adódó módon nemcsak az örökhagyó, hanem a kkt. tartozásaiért is felelni fog a hagyatéki tartozásokért való felelösség polgári jogi szabályai szerint. Ez adott esetben a lehetséges örököst ahhoz is vezetheti, hogy inkább az örökség visszautasítását mint opciót fogja választani," ${ }^{399}$ ami összhangban áll a Ptk. 3:139. § (4) bekezdésével. ${ }^{400}$ Ezzel az állásponttal nem tudok maradék nélkül egyetérteni. Az idézett rész azt sugallja, hogy az örökös automatikusan a társaság tagjává válik, holott ennek - helyes - ellenkezőjét hangsúlyozta a megfelelő szakasz kommentárjánál. A kkt. tartozásaiért az említetteknek megfelelően, ha az örökös nem kíván belépni a társaságba, akkor a hagyatéki tartozásokért való felelősség szabályai szerint felel az örökhagyó halála elött keletkezett követelésekért, azaz nem a saját teljes vagyonával, hanem azzal a résszel, amit jogelődjétől örökölt. Ezért nem tartom indokoltnak, hogy visszautasítsa az örökséget, miután a tartozásokért való helytállása csak cum, illetve pro viribus lehet. Ettől természetesen teljesen eltérő megítélés alá esik az a körülmény, ha belép a társaságba: ekkor lesz igaz, hogy a saját vagyonával is felelni fog a társaság tartozásaiért, de ez a helytállási kötelezettség az örökös saját döntése, nem kapcsolódik az öröklés ipso iure jellegéhez, az öröklés csupán azt tette lehetővé, hogy adott esetben (az örökös és a társaság közötti megegyezéstől függően) ne teljesítsen vagyoni hozzájárulást.

A Gt. 103. § (az örökös belépésének általános megfogalmazása, lásd Ptk. 3:149. §) alkalmazásában a meghalt tag örökösén csak az állagörököst kellett érteni, tehát ő válhatott a társaság tagjává. A haszonélvezeti jog örökösét csak a tagsági jogból fakadó vagyoni jogok (,,a hasznok szedése”) illetik meg, de a szavazati jog (mint „,rendelkezési jog”) az állagörökösé. ${ }^{401}$

A közkereseti társaságnál is a vagyoni hozzájárulás mértéke több esetben meghatározó lehet, mint pl. az adózott nyereség szétosztásakor, vagy a veszteségviselés

\footnotetext{
397 Török T. 2015. 238.

${ }^{398}$ Kisfaludi 2014b. 363.

${ }^{399}$ Boóc 187.

${ }^{400}$ Uo.

${ }^{401}$ Wellmann 7.
} 
esetében. Ha nem számolnak el a meghalt tag örökösével, aki ugyan belép a társaságba, legalábbis forma szerint a vagyoni hozzájárulása nem határozható meg. Ha több örökös van és nem mindegyik lép be tagként a társaságba, vagy nem mindegyik örökössel állapodnak meg a tagok a belépést illetően, akkor az egyes örökösök örökrészét csak akkor lehet megállapítani, ha a volt tag örököseivel - tehát azzal is, aki belép ugyan tagként a társaságba - megfelelő formában elszámolnak. ${ }^{402}$

Összefoglalva elmondható, hogy maga a közkereseti társaságbeli tagsági viszony nem örökölhető. Ilyen körülmények között az egyébként jogutódnak a társaságba tagként történő belépése nem a jogelőd tag tagsági viszonyának a folytatása lesz, hanem új tag felvételét jelenti és mindazokat a lépéseket meg kell valósítani, amelyeket az új tag felvételére a Ptk. elöír.

Az osztrák személyegyesítő társaságokban fellelhető társasági részesedések sorsa attól függ, hogy a törvénybeli diszpozitív jogi helyzet vagy társasági jogi elöírások érvényesülnek. Társasági szerződésbeli elöírás hiányában nem léphetnek be az örökösök a társaságba a korlátlanul felelős tag helyére, csak a rájuk jutó örökrész erejéig nekik jutó kiegyenlítésre tarthatnak igényt, de a társasági szerződésben még ezt az igényt kizárhatják. ${ }^{403}$

\subsubsection{Betéti társaságok}

A betéti társaságokra a Ptk. 3:155. § [Gt. 108. § (3) bek.] alapján - eltérö rendelkezés hiányában - a közkereseti társaságokra vonatkozó szabályokat kell alkalmazni. A társasági jog és öröklési jog kapcsolódásánál azt az eltérést szabályozza a Ptk. [Gt.], ami a betéti társaság fogalmából ${ }^{404}$ is ered, azaz a legalább két tag eltérő felelősségéből, nevezetesen amennyiben valamelyik státuszból minden tag kiválik, így pl. elhalálozik, és 6 hónapon át nem cselekszenek a törvény előírásának megfelelően,

úgy a társaság megszünik, amelynek a következményeit a 4.1.2.2. pontban érintettem. ${ }^{405}$ Az előbbiekben a közkereseti társaságnál megállapítottak tehát a betéti társaságokra is ugyanúgy irányadóak, tehát a betéti társasági tagsági jogviszony sem örökölhető ipso

\footnotetext{
402 Besenyei 2004. 502.

${ }^{403}$ Kalss - Probst 668.

${ }^{404}$ Ptk. 3:154. §, Gt. 108. § (1) bek.

${ }^{405}$ Ptk. 3:158. §, Gt. $110 . \S$
} 
iure. $^{406}$ Egyúttal megjegyzendő, hogy a betéti társaság kültagja nem felelős a társaság vagyona által nem fedezett tartozásokért.

A meghalt tag jogutódja, amikor belép a társaságba, új tagnak számít, a társasági szerződésben pedig kötelező elemként fel kell tüntetni a vagyoni hozzájárulását. ${ }^{407} \mathrm{~A}$ kkt.-nál kifejtett elszámolási okok közé illeszthetően a vagyoni hozzájárulásra vonatkozó pontos adat csak akkor adható meg, ha az örökös (belépő tag) és a társaság elszámol egymással. Ahogy jeleztük, az sem kizárt, hogy a jogutód új tag nagyobb vagy éppen kisebb vagyontömeggel vegyen részt a társaságban. Söt az sem kizárt, hogy az örökhagyó a társaság beltagja volt és az örökös kültagként lép be a társaságba, vagy éppen fordítva, az örökhagyó kültag volt és az örökös beltagként lesz a társaság tagja. ${ }^{408}$

Maga a törvény is lehetőséget ad arra, hogy a tagok a korábbi tagi pozícióikat megváltoztassák, amivel azonban előtérbe kerül a mögöttes helytállási kötelezettség kérdése. Ha egy korábbi kültag beltaggá válik, akkor ez a változás a hitelezők számára egyértelmüen kedvezőbb, hiszen az ő teljes vagyona is fedezetet nyújt akkor, ha a követeléseket a társaság vagyona nem fedezi. Ellenkező esetben, ha a társaság beltagja kültaggá válik, a kültaggá válástól számított ötéves jogvesztő határidőn belül a beltagra vonatkozó rendelkezések szerint áll helyt a módosítást megelőzően keletkezett társasági tartozásokért. $^{409}$ Mindez, ahogy azt a törvény indokolása is kiemeli, a hitelezői érdekeket védi. ${ }^{410}$

A Ptk. hatályba lépésével kérdésként merült fel a 3:4. §-ban foglalt diszpozitivitási teszt alapján egyes jogvesztő határidőktől (így a társaság megszünésére vonatkozó hathónapos határidő) való eltérés lehetősége. Dzsula Marianna vetette fel azt cikkében, ${ }^{411}$ honnan tudhatná például azt a hitelező, hogy az adott kéttagú betéti társaság a beltag halálát követően nem a 6 hónapos jogvesztő határidő után fog megszünni, hanem a létesítő okiratában szereplő kéthónapos határidő elteltével? Álláspontom szerint ilyen eltérés a Ptk. megfelelő értelmezésével nem lehetséges. A jogvesztő határidőktől való eltérés önmagában ellentétes a jogintézmény céljával, ami szerint a határidő elteltével maga a jog is elenyészik, arra az idő múlásával már nem lehet hivatkozni, azt már érvényesíteni sem lehet, az ilyenek alkalmazását éppen a

\footnotetext{
406 ÍH 2015. 154.

${ }^{407}$ Ptk. 3:5. § e) pont

${ }^{408}$ Besenyei 2004. 502.

${ }^{409}$ Ptk. 3:157. §

${ }^{410}$ T/7971. számú törvényjavaslat a Polgári Törvénykönyvröl; Nochta 2014b. 569-570.

${ }^{411}$ Dzsula 2014a. 3-5.
} 
forgalom biztonsága (beleértve a jogos hitelezői igények kielégítése is) követeli meg. ${ }^{412}$ Az eltérés lehetősége azért sem állhat fenn, mert a határidő elteltével egy jogalany szünik meg.

Az osztrák bt.-k társasági szerződésbeli ellenkező kikötése hiányában a kültag helyére az öröklési jognak megfelelő jogutódlás következik be, míg a beltagok vonatkozásában igazak lesznek a közkereseti társaságnál írt megállapítások. ${ }^{413} \mathrm{E}$ megoldás (ti. a kültagi pozícióban öröklési jognak megfelelő jogutódlás) átvétele a magyar jogba megvalósítható, a kültagként belépö örökös helytállása nem lesz terhesebb az örököshöz képest. Ugyanakkor ez az automatizmus ellentmondana a vállalkozási és társulási szabadság elvének, ${ }^{414}$ mert ezzel a betéti társaságba való belépésre kényszerítenénk az örökösöket. Éppen ezért elméleti síkon bizonyos pontig lehet efféle megoldáson gondolkodni, azonban az egyik legfontosabb társasági jog alapelven megbotlik, amelynek ilyen irányú korlátozásához nem füződik olyan többletérdek, mint a többi (alanyi, tárgyi, módbeli) korláthoz. Annyiban lehet csak igazolni ilyen érdeket, amennyiben a törvényben a társaság jogutód nélküli megszünéséhez vezető okot kívánnának ekképp orvosolni, ez azonban csak a kültagi pozíció kiüresedését akadályozhatná meg, nincs értelme a tagok között ilyen különbséget tenni.

\subsubsection{Korlátolt felelösségü társaságok}

A korlátolt felelősségü társaság ${ }^{415}$ a gazdasági társaságok személyegyesítő és vagyonegyesítő elemeit is ötvözi.

A kft. fogalma magában hordozza e társasági forma legfőbb tulajdonságait. „A társaság elnevezése azt a látszatot kelti, mintha a gazdasági társaság a hitelezők felé korlátozott felelősséggel tartozna. Ez nem felel meg a valóságnak, hiszen a korlátolt felelősségü társaság a többi gazdasági társasághoz hasonlóan a hitelezők irányában teljes vagyonával felel." ${ }^{„ 416}$ A közkereseti és betéti társaság tagjaitól eltérően (hasonlóan a részvénytársaság részvényeséhez) nincs olyan tagja, akinek felelössége a társaság vagyona által nem fedezett tartozásokért korlátlan lenne. Ki kell azonban emelni azt,

\footnotetext{
${ }^{412}$ Vö. Lábady 232.

${ }^{413}$ Kalss - Probst 668.

${ }^{414}$ Papp 2011b. 27.

${ }^{415}$ Gt. 111. § (1) bek.

${ }^{416}$ Papp 2011 b. 397.
} 
hogy a tagok helytállási kötelezettsége a jogutód nélkül megszünt társaság tartozásaiért vagyoni jellegü, mögöttes, felróhatóság nélküli és ipso iure, törvényen alapuló. ${ }^{417} \mathrm{~A}$ felelősségátvitel, $^{418}$ valamint a felelősségáttörés ${ }^{419}$ (jogi személy elkülönült jogalanyiságával visszaélés) tényállásának fennállása (amely a betéti társaság kültagja vonatkozásában is releváns), az apport túlértékelése, ${ }^{420}$ az apport túlértékelésének rosszhiszemű elfogadása, ${ }^{421}$ a legfőbb szerv határozatának rosszhiszemü elfogadásáért, ${ }^{422}$ az ellenőrzött társaság felszámolásáért ${ }^{423}$ való helytállás esetében is felelősséggel tartozik a tag, amely miatt fennálló kötelezettségeket örökölhet adott esetben az örökös, és mint hagyatéki tartozás kiegyenlítéséért, ahogy azt később kifejtem, felelősséggel tartozik. ${ }^{424}$

A Ptk. 3:161. § (1) bekezdése szerint a törzsbetét a tag vagyoni hozzájárulása. A tagok törzsbetétei különböző mértéküek lehetnek; az egyes törzsbetétek mértéke nem lehet kevesebb százezer forintnál. A társaság cégjegyzékbe való bejegyzését követően a tagok jogait és a társaság vagyonából őket megillető hányadot az üzletrész testesíti meg. A társasági szerződés eltérő rendelkezése hiányában az üzletrész mértéke a tagok törzsbetétéhez igazodik, ${ }^{425}$ forgalomképes jog- és kötelezettségösszesség, azonban az üzletrész fogalma, értéke, mértéke nem feltétlen azonos a tag törzsbetétjével. ${ }^{426}$ „Az üzletrész nem más, mint a korlátolt felelősségü társaság tagját a társaság tagsági jogviszonya alapján megillető jogosultságok és az öt terhelő kötelezettségek összessége, amely jogosultságok és kötelezettségek az üzletrész fogalma alatt összefoglalva, egységet alkotva, egymástól elválaszthatatlanul különböző jogviszonyok tárgyai lehetnek: például átruházhatók, örökölhetők.” ${ }^{427}$ Egyetértek azzal az állásponttal, miszerint a Gt.-hez képest helyesebb az üzletrész Ptk.-beli megfogalmazása, mert a korábbi jogirodalmi álláspontokkal egyezően tartalmazza a tagokat terhelő kötelezettségeket. $^{428}$

\footnotetext{
${ }^{417}$ Papp 2011b. 355.

${ }^{418}$ Ptk. 3:2. $\S(2)$ bek.

${ }^{419}$ Ptk. 6:540. $\S(3)$ bek.

${ }^{420}$ Ptk. 3:10. § (3) bek.

${ }^{421}$ Ptk. 3:99. § (2) bek.

${ }^{422}$ Ctv. 118. § (2) bek.

${ }^{423}$ Gt. 54. § (2) bek.

${ }^{424}$ Papp 2013. 242-258.

${ }^{425}$ Gt. 121. § (1) bek.

${ }^{426}$ Barta 2016b. 163.

${ }^{427}$ Kisfaludi - Szabó 877.

${ }^{428}$ Pintér 15.
} 
A fentiekből levezethető, hogy az egyes tagokat megillető üzletrészek alapját az általuk teljesített törzsbetétek képezik, az üzletrészek a tagok tulajdonában állnak, az üzletrészek mértéke pedig eltérő is lehet. Az üzletrész öröklési jogi szempontból nem kifejezetten személyhez kötődő jellegénél fogva a hagyatékhoz tartozik. Az üzletrész öröklése a korlátolt felelősségü társaság természetes személy tagjának halálakor a hagyatékba tartozó üzletrésznek a tag örökösére történő átszállása a polgári jog öröklésre vonatkozó szabályai szerint. ${ }^{429}$ Amennyiben üzletrész öröklésére kerül sor, azt az üzletrész átszállásának nevezzük.

Az üzletrészhez kapcsolódnak a tagsági jogok és kötelezettségek is, előbbiek közé tartozik a taggyülés által meghozott határozatok felülvizsgálatának kezdeményezése iránti jog. Az üzletrész hiába forgalomképes, egyes jogosultságok mégsem szállnak át, ezek közé tartozik például az említett jogosultság: a tényállás szerint az örökhagyó egy taggyülési határozat ellen szavazott, de a taggyülés meghozta a határozatot, aminek felülvizsgálata érdekében pert kezdeményezett. A peres eljárás időtartama alatt elhunyt a felperes, az örökhagyó tag, örököse pedig perbe szeretett volna lépni. Az eljáró bíróság megállapította, hogy a tag tagsági jogviszonya megszünt, az örökösnek új tagsági jogviszonya keletkezett a társasággal, azaz nem önmagában a tagsági jogviszonyban következett be az öröklés, ezért a taggyülési határozat felülvizsgálatának kezdeményezésének joga sem szállt át az örökösre. ${ }^{430}$

„A korlátolt felelősségű társaság - bár hordoz magán személyegyesítő jegyeket - lazább szálakkal kötődik a társaság tagjainak személyéhez, így megengedhető az, hogy a törvény erejénél fogva bekövetkező alanyváltozások álljanak be a társaság tagságában."431 Az öröklés miatt bekövetkező tagváltozást, ha a társaság személyegyesítő jellegét szeretnék hangsúlyozni, és az alapítók ragaszkodnak az eredeti tagi összetételhez, korlátozni tudják a társasági szerződésben a vonatkozó szabályok betartásával. Az új tag ugyanis olyan mértékben befolyásolhatja a társaság müködését, amely nem felel meg az érdeküknek. ${ }^{432} \mathrm{Ez}$ a lehetőség a Ptk. hatályba lépésével jelentősen beszükülve, de továbbra is lehetséges.

A jogszerzés a halál pillanatában következik be, azonban ahhoz, hogy ez a társasággal szemben is hatályos lehessen, az öröklés tényét a társaságnak be kell jelenteni és igazolni is kell. Egyidejüleg kérni kell a társaság ügyvezetőjét, hogy a

\footnotetext{
${ }^{429}$ Kisfaludi - Szabó 943.; Fővárosi Ítélőtábla 13. Gf. 40.338/2011/6.

${ }^{430}$ ÍH 2015. 119.

${ }^{431}$ Uo.

${ }^{432}$ Lörinczi 12-13.
} 
tagjegyzéket megfelelően módosítsa, majd a cégbírósághoz változásbejegyzési kérelmet nyújtson be az öröklés útján taggá vált személynek a cégjegyzékbe történő bejegyzése érdekében. Az örökösi minőség igazolására alkalmas lehet egy jogerős hagyatékátadó végzés, öröklési perben hozott jogerős bírósági ítélet vagy öröklési bizonyítvány is. ${ }^{433}$ Egyúttal a kkt. és bt. vonatkozásában releváns megállapítások is igazak: a hagyatéki eljárás, illetve adott esetben öröklési per jövőbeli bizonytalan időpontbeli befejezésétől függő jogi tények miatt a tagjegyzék módosítása, ezzel együtt a tagsági jogok gyakorlási lehetőségének kezdete is eltolódik az öröklés tényleges megnyílásától. (Kérdéses lehet ennek helyessége olyan esetekben, ahol az örökös személye viszonylag könnyen megállapítható, mint például végrendeleti öröklés esetén, vagy például ha az örökhagyó egyedüli gyermeke a törvényes örökös. A forgalom biztonsága miatt azonban szükséges egy olyan eljárás - akár a hagyatéki eljárás, akár öröklési per - lefolytatása, aminek jogerős befejezésével az örökösi minőség nem vitatható el.) Az elhunyt tag üzletrészére a jogutód öröklése a tag - mint örökhagyó - halálával ipso iure megnyílik, s a tagsági viszony megnyílásával az örökös, a jogelődjének pozíciójába lép. Természetesen ez nem teszi szükségtelenné az örökhagyó ezen üzletrészére - mint hagyatéka egy részére is - vonatkozóan a hagyatéki eljárás lefolytatását és örökösi minőségének deklarálását. Szükséges az örökös tagi minőségének a cégjegyzékbe való bejegyzése, a tagjegyzékbe öröklés jogcímén taggá válásának a felvétele is. ${ }^{434}$

Korlátolt felelősségü társaságoknál szintén az örökösök elhatározásán múlik, tovább szeretnék-e vinni jogelödjük részét, a tag halála esetén örököse - az örökösi minőség igazolása mellett ${ }^{435}$ - a Ptk. megfogalmazása szerint kérheti az ügyvezetőtől a tagjegyzékbe való bejegyzését. ${ }^{436}$ Itt is szükséges tehát az, hogy az örökös kiléte egyértelműen megállapítható legyen, ennek európai szintű egységesítése érdekében vezették be az európai öröklési bizonyítványt, amelynek használata nem kötelező, ${ }^{437}$ azonban célszerü. A bizonyítvány a teljes hatályú hagyatékátadó végzés, a teljes hatályúvá vált ideiglenes hatályú hagyatékátadó végzés, valamint az ideiglenes hagyatékátadó végzéssel érintett valamennyi igény bírósági elbírálása esetén hozott hagyatéki eljárást befejező végzés jogerőre emelkedését követően kérhető, ezeket az időpontokat megelőzően csak a végrendeleti végrehajtó, a hagyatéki gondnok, valamint

\footnotetext{
${ }^{433}$ Kisfaludi - Szabó 944.

434 Tarr 276.

${ }^{435}$ Kisfaludi - Szabó 944.

${ }^{436}$ Ptk. 3:170. §

${ }^{437}$ (69) preambulum-bekezdés
} 
a hagyatékbeli társasági részesedés, illetve követelés miatt kirendelt ügygondnok kérelmezheti ebbéli jogosultságuk bizonyítására a hagyatéki eljárást lefolytató közjegyzőnél. ${ }^{438}$ A kérelem, valamint a bizonyítvány formanyomtatványát a Bizottság 1329/2014/EU rendelet, az öröklési rendelet végrehajtási rendeletének 4., illetve 5. melléklete tartalmazza.

Az európai öröklési bizonyítványt azért alkották meg, hogy az Unióban a határokon átnyúló vonatkozású öröklések gyors, zökkenőmentes és hatékony rendezése érdekében az örökösök, hagyományosok, végrendeleti végrehajtók, illetve a hagyatéki gondnokok egy másik tagállamban, például a hagyatéki javak fellelhetősége szerinti tagállamban könnyen igazolni tudják jogállásukat, jogaikat és jogosítványaikat. A bizonyítvány nem veheti át a tagállamokban hasonló célokra esetlegesen létező belső okiratok helyét. ${ }^{439}$

Az öröklési bizonyítvány önmagában nem képez végrehajtható jogcímet, azonban bizonyító erővel bír, továbbá feltételezni kell, hogy hitelesen bizonyítja az öröklésre alkalmazandó jognak vagy a bizonyos tényezőkre alkalmazandó egyéb jognak megfelelően megállapított tényezőket, például a végintézkedések tartalmi érvényességét. $^{440}$

A rendelkezésnek az a kifejezése, miszerint ,az örökös kérheti a tagjegyzékbe való bejegyzést" azt sugallja, bizonyos szempontból ellentétben Pázmándi Kinga megjegyzésével, miszerint az üzletrészek öröklésére vonatkozó új szabályozással erősödött az ipso iure jelleg, mégsem valósult meg maradéktalanul. Ezért azt is meg kell vizsgálni, mi történik abban az esetben, ha nem kéri az örökös a tagként való bejegyzését, ami történhet kifejezett nyilatkozattal és hallgatólagosan. Meglátásom szerint először meg kell nézni a társasági szerződést, rendelkeztek-e abban az üzletrész megváltásáról. Ha igen, és az erre feljogosított személyek hajlandóak a megváltásra, úgy biztosítva nekik ezt a jogot, megválthatják az üzletrészt kifizetve annak forgalmi értékét. Ha nincs meghatározva ilyen személy a társasági szerződésben, vagy nem kíván élni ezzel a jogával (ugyancsak kifejezett nyilatkozattal vagy nem nyilatkozik a Ptk.-ban meghatározott 30 napos jogvesztő határidő alatt), abban az esetben az üzletrészt bevonják, és annak értékét a társaság az örökös részére kifizeti. Bizonyos idő után a társaság számára is nyilvánvalóvá fog válni, hogy valamely tag meghalt, ekkor a

\footnotetext{
${ }^{438}$ Hetv. 102/B. § (1)-(3) bek.

439 (67) preambulum-bekezdés

${ }^{440}$ Vö. (71) preambulum-bekezdés
} 
társaság számára fennáll az a lehetőség, hogy nyilatkoztassa az örököst a belépés szándékáról, hiszen a Ptk. nem zárja ki ezt, és ha az örökös igenlően válaszol, akkor is az örökös fogja kérni a tagként történő bejegyeztetést. Ha nemleges választ ad, akkor a társaság is tud annak érdekében tenni, hogy ez az átmeneti állapot (valamely üzletrésznek nincs tulajdonosa) minél hamarabb megszünhessen.

„Az üzletrész nem dolog. Az üzletrész akkor is ,jogösszesség”, ha annak dologiasodása kétség kívül megfigyelhető. Ezért az üzletrész öröklése esetében sem alkalmazhatók kizárólag az öröklés dologi jogon alapuló szabályai, hiszen az üzletrész nem csupán vagyoni érték, hanem egyben társasági státuszt is jelent, azaz az örökös (jogutód) „tulajdonába” nem csupán egy vagyoni érték kerül, hanem tagjává is válik egy társaságnak. A társaság zártságának elvén a korábbi társasági jogok is tartalmazták, hogy az örökléssel a jogutód csak a társaság beleegyezése, akarata (ez alatt nyilvánvalóan azt kell érteni, hogy a társasági szerződésben a tagok kiköthették azt, hogy öröklés esetén nem szállhat át az üzletrész - megjegyzés a szerzőtől) alapján válhat a társaság tagjává. Ha a társaság olyan szabályokat érvényesít a társasági szerződésében, ami ezt kizárja, úgy a jogutóddal természetesen el kell számolni (azaz „kiadni neki, ami jár”). [...] A Ptk. rendelkezésének szövegezése - a diszpozitív szabályozási módszer miatt is - némileg megfordítani látszik a korábbi szabályozás egyenes vonalú logikáját. Az átszállás szabályát kifejezetten nem mondja ki (csak a szakasz címében utal rá), azonban azt adottnak veszi, amikor abból indul ki, hogy az örökös önmagában a jogutódlás igazolásával kérheti a tagjegyzékbe való bejegyzését." ${ }^{441}$

A korlátolt felelősségü társaság tagjaiban bekövetkezett változást - a tagváltozás szabályszerü bejelentése esetén - az ügyvezető köteles haladéktalanul átvezetni a tagjegyzéken az üzletrész megszerzésének időpontjával, és ezt a cégbírósághoz bejelenteni. A Gt. szabályozása alapján mondta ki a Fővárosi Ítélőtábla, hogy a tagsági jogok az új tagot a tagsági jogviszonyának ügyvezetőhöz való szabályszerü bejelentésétől kezdődően megillették. ${ }^{442}$ A vonatkozó döntés a tagjegyzékben bekövetkező változásokkal kapcsolatban merült fel. A Gt. 150. § (3) bekezdése még példálózó jelleggel megemlítette az üzletrész átszállását, mint a tagok személyében vagy az üzletrészekben bekövetkezett változást, amelyet át kell vezetni. Ehhez képest a Ptk. 3:197. § (3) bekezdése szerint a tagjegyzék adataiban bekövetkező változásokat

\footnotetext{
${ }^{441}$ Pázmándi 2014b. 634.

${ }^{442}$ BDT 2014. 3164., Gt. 150. § (3) bek.
} 
kell átvezetni, amibe bele kell érteni az üzletrészeket is, mert a tagjegyzék tartalmi elemei közé tartozik valamennyi tag megjelölése és a törzsbetéteik mértéke. ${ }^{443}$ „A tagjegyzék a kötelező cégiratok része, azaz azt - illetve a tagjegyzéket érintő bármely adat megváltozásakor annak hatályosított változatát - a közhiteles cégnyilvántartásba is be kell nyújtani." ${ }^{444}$ Ha nem kerül sor az adatok átvezetésére - ezek közé az adatok közé tartozik a tagok és az ügyvezető személye is -, akkor törvényességi felügyeleti eljárást kell lefolytatni, a lehetséges intézkedések közül a cégbíróságnak azt kell alkalmazni, amelyik az adott esetben a legalkalmasabb a cég törvényes müködésének helyreállítására. ${ }^{445}$

Bizonyos személyektöl - például az elhunyt tag hozzátartozóitól - a társaság tudomást szerezhet arról, hogy valamely tag meghalt, ugyanakkor az örökös kilétéről nem ismerhet minden kétséget kizáró információt, különösen akkor nem, ha öröklési jogi vita merült fel. A társaságnak ugyanakkor nincs lehetősége arra, hogy „nyomozzon” az örökös után, saját kezdeményezésére nem tudja megállapítani az örökös személyét, ez a társaságra nézve nagy terhet róna. Se a Gt., se a Ptk. nem ír(t) elő olyan kötelezettséget, hogy az örökösnek vagy a jogutódnak be kellene jelentenie a jogutódlás bekövetkeztét. A törvénykönyvek ugyanis halál esetén az örökös kezdeményezését, pontosabban e személy kérelmét tartalmazták. Az örökösök saját jól felfogott érdeke az, hogy a bejelentést megtegyék, mert ezzel válnak képessé a tagsági jogok gyakorlására, ${ }^{446}$ ennek formája - az üzletrész átruházása során alkalmazandó szabályok analógiájára - közokirat vagy teljes bizonyítóerejű magánokirat. ${ }^{447} \mathrm{Ha}$ az örökösök nem jelentkeznek a társaságnál, úgy az üzletrész megszerzése sem valósulhat meg jogilag értékelhető szempontból. Ennek az állításnak nem mond ellent a magyar öröklés ipso iure jellege, mivel több más vagyontárgy, így például ingatlan teljes jogú megszerzéséhez az öröklési jogcímen az ingatlan-nyilvántartásba való bejegyzés is szükséges, mert ennek hiányában például nem tudja átruházni azt, tehát a rendelkezés jogát érinti. A cégbíróság esetleg értesülhet a tag haláláról a társaság bejelentése alapján vagy a közjegyző megküldi a hagyatékátadó végzést. ${ }^{448}$

A Ptk. 3:168. § (2) bekezdése ugyan az átruházás bejelentése esetén irányadó szabályokat tartalmazza, de öröklés esetén is nyilatkozni kell, hogy az új tag a társasági

\footnotetext{
${ }^{443}$ Ptk. 3:197. § (2) bek. a) pont

${ }^{444}$ Pázmándi 2014b. 606.

${ }^{445}$ BDT 2014. 3166.

${ }^{446}$ Kisfaludi - Szabó 948.

${ }^{447}$ Barta 2012. 13., Ptk. 3:168. § (2) bek.

${ }^{448}$ BDT 2014. 3166.
} 
szerződés rendelkezéseit magára nézve kötelezőnek ismeri-e el. Ha ez nem lenne megkövetelhetö, akkor az örökössel szemben nem lehet ezeket a rendelkezéseket kikényszeríteni, amennyiben nem volt korábban a kft tagja. ${ }^{449}$ A társasági szerződés tartalma pedig különösen jelentős akkor is, amennyiben a Ptk. adta lehetőségek mentén eltérnek a törvény szövegétöl. A törvény nem rendelkezik azokról a jogkövetkezményekröl, mi történik, ha nem jelentik be a tagváltozás tényét, de az megállapítható, hogy ez a probléma a társaság müködése során előtérbe fog kerülni, gondoljunk például a döntéshozatali mechanizmusra. A forgalom biztonsága, valamint a cégjegyzék közhitelességének előmozdítása érdekében megfelelőnek tartjuk Barta Judit szintén az üzletrész átruházásának szabályaiból átemelt analógiáját a kérelem előterjesztésének határidejére vonatkozóan, ami az örökösi minőséget igazoló okirat (jogerős hagyatékátadó végzés, öröklési per esetén jogerős ítélet, valamint öröklési bizonyítvány) megszerzésétől számított nyolc nap. ${ }^{450}$ Indokolja ezt az is, hogy a Ptk. külön nem határoz meg a bejelentésre vonatkozó határidőt, és nem érvényesül rá az a szabály, miszerint ha a Ptk. nem határoz meg adott jognyilatkozat megtételére vagy cselekmény elvégzésére határidőt, akkor azt késedelem nélkül kell megtenni, ${ }^{451}$ ugyanis az örökös tagként való belépésére irányuló jognyilatkozat nem kötelezö; a törvényszövegben az szerepel, hogy kérheti tagként való bejegyzését az ügyvezetőtől az örökhagyó halálának esetére. ${ }^{452}$

További kérdések is felmerülhetnek:

a) Mi a megoldás akkor, ha több örökös van? Hogyan lehet biztosítani a törzsbetét minimumra vonatkozó szabályt, ha az örököstársak nem akarnak közös tulajdonú törzsbetétet? A közös tulajdon fenntartására senkit nem lehet kötelezni; sőt a Ptk. éppen arra koncentrál, hogy bármelyik tulajdonostárs, elvben bármikor, követelhesse a közös tulajdon megszüntetését. ${ }^{453}$

Több örökös esetén az örökhagyó üzletrésze vonatkozásában közös tulajdon fog keletkezni, ha ezt meg kívánják szüntetni, fel kell osztani az örökösök között. Ha ez által nem érnék el az egyes törzsbetétek a minimumot, akkor a felosztás meghiúsul. Megoldást jelenthet az, hogyha valamely örökösök mindenképpen tagok szeretnének lenni, akkor tőkepótlással megfelelő

\footnotetext{
${ }^{449}$ Barta 2012. 13.

${ }^{450}$ Barta 2012. 14., Ptk. 3:168. § (2) bek.

${ }^{451}$ Ptk. 3:91. $\S(3)$ bek.

${ }^{452}$ Ptk. 3:170. § (1) bek.

${ }^{453}$ Besenyei 2009. 36.
} 
elszámolás mellett legalább az egy tagra irányadó minimum százezer forintra egészítik ki az egyes törzsbetéteket, ami természetesen több is lehet ennél az összegnél.

b) Ha jelentős befolyással rendelkező tag hal meg, és például csak végrendeleti örökösei vannak, de az egyébként törvényes örökösöknek minősülő személyek vitatják a végrendelet érvényességét és pert indítanak az érvénytelenség kimondása érdekében, mindaddig, amíg ezek a perek le nem zárulnak, a taggyülés nem tud érdemi döntést hozni. Az örökös ugyan az öröklésre vonatkozó szabályok szerint a halál pillanatában megszerzi a hagyaték tulajdonjogát, jelen esetben a tagsági jogot, de az abból származó jogait a fent vázolt körülmények miatt nem tudja gyakorolni. Csak jogerős bírói ítélet birtokában lehet megmondani, hogy ténylegesen ki az örökös, vagyis ki jogosult a tagsági jogviszonyból származó jogok gyakorlására. ${ }^{454}$

$\mathrm{Az}$ öröklés az üzletrész létrejöttének időpontja tekintetében bizonyos szempontból problémát jelenthet. Az üzletrész a cégbejegyzéssel jön létre, ${ }^{455}$ és elképzelhető, hogy a társasági szerződés aláírásától számítva viszonylag későn kerül sor erre. Ezért létezik olyan nézet, miszerint tekintettel arra, hogy az üzletrész a tagsági jogok és kötelezettségek összessége, ezek az előtársasági létszakaszban nem is léteznek, az üzletrész nem ruházható át, ad absurdum az nem lehet a hagyaték tárgya. ${ }^{456}$ Ehhez képest a 4.1.1. pontban kifejtetteket figyelembe véve előtársasági létszakaszban is megvalósulhat a társaságban jogutódlás. Megjegyzendő, hogy például a vagyoni hozzájárulást teljesíteni kell az előtársaság számára is, amihez felelősségi kérdések is kapcsolódnak. $^{457}$

Ha az örökös taggá vált, jogelődje jogi helyzetébe lép, tagi felelősség fogja terhelni, amely a tag halálától terheli. Ha az örökös nem válik taggá, az örökösi minőségből eredő felelősség áll be, tehát a társaság tartozásaiért az örökhagyó üzletrésze arányának megfelelően a hagyaték tárgyaival és annak hasznaival - vagyis az üzletrésszel - felel. Előfordulhat az az eset, miszerint még az örökhagyó életében megszavazták az osztalékot, azonban halála miatt nem fizették ki azt számára. Ez az osztalék is megilleti az örökösöket az öröklés folytán, ${ }^{458}$ azaz ezzel is helyt kell állnia a

\footnotetext{
${ }^{454}$ Besenyei 2009. 36.

455 Ptk. 3:164. $\S(1)$ bek.

456 Pintér 17.

${ }^{457}$ Papp 2011b. 100-106.

${ }^{458}$ Barta 2017. 89.
} 
hagyatéki tartozásokért. Ez a felelősség az örökhagyó haláláig - tehát az örökhagyó tagsági viszony megszűnéséig - keletkezett társasági tartozásokra terjed ki. ${ }^{459}$

A törzsbetét szolgáltatása kötelező, vagyoni hozzájárulás teljesítése nélkül nem lehet tagként részt venni a társaságban. Ez a társaság müködése során is irányadó, így amennyiben az újonnan csatlakozó tag nem üzletrész átruházásával - vagy egyéb jogcímen, így például örökléssel való átszállásával - csatlakozik a társasághoz, szintén törzsbetétet kell szolgáltatnia (ami értelemszerüen növeli a törzstőkét). ${ }^{460}$ Lehetősége van az örökösnek arra, hogy további szolgáltatást is teljesítsen, ha ilyen módon meg szeretné növelni az üzletrészét, ezzel együtt a törzstőkét.

\subsubsection{Az üzletrész átszállása}

A Gt. 128. § (1) bekezdése szerint a tag halálával üzletrésze átszállt a jogutódjára.

Felvetődött az a nézőpont a jogirodalomban, hogy a Ptk. kodifikációjával a megfelelő terminológia elérhető lenne ebben a tekintetben, hiszen a természetes személy halála folytán bekövetkező jogutódlás öröklés, és a jogutód elnevezése örökös. ${ }^{461}$ Alapvetően helyeselhető lehetne ez a nézet, amihez képest a Gt. gyüjtőfogalomként nevesítette az átszállást: a jogelőd jogképességének megszünése (és ebbe az ember halálát és a jogi személy jogutóddal való megszünését is bele kellett érteni) folytán a tagok személyében nem jogügyleti jogcímen bekövetkező alanyváltozása, jogutódlása. ${ }^{462}$ A letisztult fogalom miatt nem okozhatott a gyakorlatban problémát a törvényszöveg megfelelő nyelvtani értelmezése. Kétségtelen, hogy jobban meggyökeresedett a természetes személy halála miatti jogutódlás tekintetében az öröklés kifejezés, de véleményem szerint nem volt szükség erre a javításra a kodifikáció során, különben ezzel megkettőződött volna a vonatkozó szakaszban a normatartalom.

A társasági szerződés kizárhatta az átszállást - erősítve ezzel a személyegyesítő jegyeket ${ }^{463}$-, ekkor rendelkezni kellett az üzletrésznek a tagok vagy a társaság által történő megváltásáról. „A társasági szerződés megkötésekor tehát maga az örökhagyó az, aki a szerződés aláírásával eltér az öröklés általános szabályaitól, és a megváltás lehetőségének vállalása révén örököseit kedvezőbb, vagy kedvezőtlenebb helyzetbe

\footnotetext{
459 Tarr 277.

${ }^{460}$ Pázmándi 2014b. 593.; Sárközy 2014. 103.

${ }^{461}$ Barta 2012. 13.

${ }^{462}$ Papp 2011b. 412.

${ }^{463}$ Nochta 2011. 288-289.
} 
hozza."464 Ennek a szabályozásnak az volt az indoka, hogy az üzletrész vagyoni és tagsági jogokat is megtestesít, így az öröklési jog rendelkezései nem alkalmazhatóak teljes mértékben. ${ }^{465}$ A KGD 2001. 2. eseti döntés szerint egy kft. tagjai akként rendelkeztek a társasági szerződésben, hogy az egyik tag halála esetén üzletrészét a többi tag „örökli”. A Legfelsőbb Bíróság megállapítása szerint a Gt. 9. § (1) bekezdésében írtak szerint a tagok csak a Gt. keretei között állapíthatják meg szabadon a társasági szerződés tartalmát, olyan döntést nem hozhatnak, hogy a meghalt tag üzletrészét a többi tag „örökli”.” A Gt. 136. § c) pont alapján a társaság rendelkezett az üzletrésszel öröklés esetén, ha a társasági szerződés az átszállást kizárta, és ha a tagok, illetőleg a társaság az üzletrészt nem váltották meg, addig, amíg a megváltás meg nem történt. Az üzletrész átszállása a törvény erejénél fogva következett be, így ezt nem kellett a társasági szerződésben szabályozni, azonban az öröklés tényét a jogutódnak be kellett jelentenie a társaság számára annak érdekében, hogy a változásokat az ügyvezető átvezesse a tagjegyzéken és kezdeményezze azok bejegyzését a cégbíróságnál. ${ }^{466}$ Amennyiben az örökhagyó üzletrészét a társaság szerzi meg, akkor az saját üzletrészt eredményez. Amennyiben eleve tag volt az örökös, úgy az üzletrésze az örökölt üzletrésszel megnövekedik. ${ }^{467} \mathrm{Ha}$ a társasági szerződés az átszállást kizárta, célszerü volt az üzletrész bevonásának lehetőségét szabályozni. A bevonás az üzletrész kft. általi ipso iure sajátos szerzésmódja, amelynek keretében a társaság az uratlanná váló üzletrészt a törzstőke leszállításával véglegesen átveszi. ${ }^{468} \mathrm{~A}$ jogeset szerinti helyzet akkor váltotta ki volna a társaság tagjai által megkívánt joghatást, ha mindegyik tag végrendelkezne, amiben az üzletrészüket tekintve a többi tagot nevezi meg örökösnek, közös tulajdont létrehozva, majd a tagok ezt felosztják. Ez a megoldás sem lehet azonban teljesen problémamentes: a tagoknak folyamatosan ügyelni kell arra, hogy mindig az aktuális tagokat tartalmazzák a végintézkedések, ami bizonyos formáknál további költségvonzatot képez.

\footnotetext{
${ }^{464}$ Adorján 2000. 343.

465 Kovács G. 96.

${ }^{466}$ Uo.

467 Gt. 121. § (2) bek. A Ptk. ezt a rendelkezést ugyan elhagyja, de továbbra is következik abból a szabályból, hogy minden tagnak egy törzsbetéte lehet. [Ptk. 161. § (2) bek.] Üzletrész törzsbetét nélkül nem létezik, és ha nem lehet egy tagnak több törzsbetéte, több üzletrésze sem lehet, azaz ha változik (növekszik) az üzletrész mértéke, akkor csak ez az egy üzletrész változhat. Ettől meg kell különböztetni a közös tulajdonban lévő üzletrészeket, amelyek nem minősülnek önálló üzletrésznek, a Ptk. megfelelő szabályai lesznek ezekre irányadóak, hiszen ők egy tagnak minősülnek a társaság felé. [Ptk. 3:165. § (1) bek.]

${ }^{468}$ Papp 2011b. 451.
} 
Ha a Gt. alapján a társasági szerződés a kft. üzletrész öröklését kizárta, a meghalt tag örökösével az üzletrész értéke alapján kellett elszámolni. ${ }^{469}$ A tényállás szerint a társasági szerződés kizárta öröklés esetén az üzletrész átszállását, ennek megfelelően az örökösök és a társaság egyeztetett a megváltási ár pontos összegéről. Ez azonban nem vezetett eredményre. „A megváltási kötelezettség tényének lerögzítésén túl az örökös (örökösök) kifizetésének legalább a fő elveit meg kell adni. Adott esetben ez az alperes társasági szerződésében nem szerepelt.” A megváltás kifizetésének fő elvei közé tartozónak minősíthető például a kifizetés módjának, illetve határidejének meghatározása. A közölt döntés további fontos megállapításokat tett, amik jelen esetben is relevánsak: az üzletrész átszállásának kizárása semmiképpen sem jelenti a kompenzáció nélküli elvonást. ${ }^{470} \mathrm{Az}$ örökössel a tag halála pillanatában fennálló társasági vagyoni helyzet szerint kell elszámolni, az örökös - ha a kft. saját tőkéje a jegyzett tőkét meghaladja - a jegyzett tőkén felüli vagyon törzsbetét arányos részére is igényt tarthat. Ha a jegyzett tőke (a törzstőke) a saját tőkével (azaz a cég tényleges teljes vagyonával) egyenlö, akkor az örököst az üzletrész névértéke (a törzsbetét) illeti meg. Ha a társaság vagyonvesztésben van, azaz a törzstőke értéke a saját tőkénél kisebb, vagy éppen negatív, akkor az örökösök arányosan kevesebb értékre tarthatnak számot az örökhagyó jogán, de lehet, hogy semmit nem kapnak. ${ }^{471}$ Felvetődhet az a kérdés, hogy az öröklés kizárása megvalósulhat-e egy meghatározott körre nézve, vagy az csak általános jelleggel lehetséges. Erre azt az adekvát választ lehet adni, miután a végrendeletekre igen kötött formát határoz meg a Ptk., ${ }^{472}$ nem lehetséges ezek megkerülése, a társasági szerződés célja szerint nem végintézkedési forma. ${ }^{473}$ Ha tehát a társasági szerződésben rendelkeznek valamilyen módon az üzletrész örökléséről, akkor az örökhagyó az, aki a szerződés aláírásával eltér az öröklési jog általános szabályaitól. ${ }^{474} \mathrm{Az}$, hogy a társasági szerződés kizárja az öröklést az üzletrész vonatkozásában, nem jelenti azt, hogy az örökös ne válhatna a társaság tagjává. Ez az eset azonban nem minősül öröklésnek, hanem élők közötti jogügyleten fog alapulni a belépés. ${ }^{475}$

\footnotetext{
${ }^{469}$ BDT 2006. 1330.

${ }^{470}$ Vö. Kisfaludi - Szabó 948.

${ }^{471}$ BDT 2006. 1330.

${ }^{472}$ Ptk. 7:13. §

${ }^{473}$ Kisfaludi - Szabó 949.

${ }^{474}$ Adorján 1999. 8.

${ }^{475}$ Kisfaludi 1991. 152-153.
} 
A megváltással kapcsolatos eljárás vonatkozásában merült fel az a bírói gyakorlatban, miszerint ilyen ügyekben a cégbíróság a változásbejegyzési eljárásban kizárólag olyan okiratok megfelelő voltát vizsgálhatja, amelyek benyújtását a Ctv. 1. és 2. számú melléklete elöírja. A Ctv. 1. és 2. számú melléklete az üzletrész öröklésének Gt. által megengedett kizárásakor fizetendő megváltással kapcsolatos okiratokra nézve rendelkezést nem tartalmaz, így ilyen dokumentum benyújtását a cégbíróság sem igényelheti jogszerüen, ${ }^{476}$ ugyanakkor célszerünek tartom a megváltozott jogszabályi változásra tekintettel ennek törvénybe való emelését. Az esetbeli társasági szerződés kizárta az üzletrész átszállását, kivéve azt az esetet, ha a jogutód a társaság valamely tagja. Ezen kívüli esetre a szerződés pontosan tartalmazta a megváltásra jogosultak sorrendjét és az üzletrész mértékének értékelését. A társasági szerződés rendelkezésének megfelelően az egyik tag halálával a többi tag törzsbetéteik arányában magához váltotta az üzletrészt, amelynek bejegyzésére kérelmet terjesztettek elő. Az első fokon eljáró cégbíróság a hagyatékátadó végzés, az öröklési bizonyítvány, valamint a megváltást tartalmazó okirat benyújtására hívta fel a társaságot. A társaság több hagyatéki tárgyalási jegyzőkönyvet nyújtott be, amelyek szerint az egyik tag hagyatéki hitelezői igényt jelentett be, amit az örökösök - az özvegy kivételével - nem ismertek el, illetve az örökösök között vita van a hagyatékhoz tartozó vagyontárgyak és azok értéke vonatkozásában. A társaság álláspontja szerint - miután a társasági szerződés kizárta az üzletrész átszállását - az üzletrész nem képezte a hagyaték részét. A vitás kérdésekre tekintettel - a cégbíróság által megkövetelt - hagyatékátadó végzés és öröklési bizonyítvány nem bocsátható ki.

A cégbíróság a hiánypótlás nem teljesítése miatt elutasította a változásbejegyzési kérelmet, mert nem került sor a hagyatéki eljárás jogerős lezárására, ezért nem állapítható meg sem az örökösök személye, sem az üzletrész értéke, így nem váltható meg az üzletrész. A végzéssel szemben a társaság fellebbezett, meglátása szerint a Ctv. alapján tagjegyzék, az üzletrész megszerzőjének a létesítő okirat magára nézve kötelezőnek elismerő nyilatkozata, valamint az üzletrész felosztására vonatkozó jegyzőkönyv csatolandó a kérelemhez. Más adatok megfelelő bizonyítása mellett kiemelte, hogy az elszámolás módjára nincsenek a törvényben meghatározott tartalmi és formai követelmények, nem kötelező taggyülést tartani, arra egyébként sem lehetne az örökösöket meghívni, mert nem tagok. A tagoknak és az ügyvezetőknek a társaság

476 ÍH 2017. 31. 
érdekei elsődlegessége alapján kell eljárni, ide sorolandó a törvényes müködés biztosítása, benne a cégjegyzékbeli adatok közhitelességének követelménye. A közhitelességet érintő körülmények azok, miszerint az örökhagyó meghalt, a társasági szerződés érvényesen kizárta az üzletrész átszállását, az örökösöknek csak kötelmi igénye lehet, nem lesznek tagok, így nem indokolt a taggyülésen való részvételük, a többi tag és az örökösök közötti elszámoláshoz nem indokolt taggyülés összehívása, a többi tag pedig a Gt. 128. §-a, valamint a társasági szerződés rendelkezése alapján ipso iure szerezte meg az üzletrészt. Az üzletrészt ilyen módon megszerző tagoknak fizetési kötelezettsége áll fenn az örökösök felé, ennek teljesítése azonban nem feltétele az üzletrész ilyen módon történő megszerzésének. A társaság kiemelte, hogy az üzletrész öröklésének kizárása jogintézménynek pontosan az a célja, hogy az örökösök közötti, vagy más öröklési jogvitától függetlenül biztosítható legyen a társaság müködése. Mindezeket az indokokat elfogadta az eljáró Fővárosi Ítélőtábla, a fellebbezést megalapozottnak találta és felhívta az első fokú bíróságot a változások bejegyzésére.

Az üzletrész átszállásával összefüggésben a Ptk. a Gt.-hez képest akként módosította a szabályozást, hogy nem zárhatják ki a tagok a társasági szerződésben az üzletrész átszállását. A tagoknak lehetőségük van arra, hogy a társasági szerződésben kijelöljék azt a személyt, aki jogosult az örököstől az üzletrészt megváltani. ${ }^{477} \mathrm{~A}$ törvény így igazodni akar az öröklés ipso iure öröklési rend elveihez, valamint a végintézkedésekre vonatkozó szabályokhoz. ${ }^{478} \mathrm{~A}$ megváltás vonatkozásában a törvény határidőt iktatott be, melynek körében a megváltás 30 napos határidejétől a társasági szerződésben a jogutód hátrányára - azaz felfelé - nem lehet eltérni. ${ }^{479}$ Teljes mértékben egyetértünk azzal az állásponttal, miszerint a törvény a társasági szerződésben „feljogosított személyek”-ről beszél, ami egyfelől azt jelenti, hogy a társaság nem válthatja magához az üzletrészt, másfelől a társasági szerződés nem csupán a tago(ka)t, hanem akár kívülálló személy(eke)t is megjelölhet a megváltás jogosultjaként. ${ }^{480} \mathrm{Ez}$ a lehetőség a társaság működőképességét, illetve fennmaradását segítheti elö, mert az örökösöknek így nincs lehetőségük, hogy a társaság vagyonára igényt tartva szerezhessék meg az örökrészüket. ${ }^{481}$ A jogszabály nyelvtani

\footnotetext{
${ }^{477}$ Vö. Ptk. 3:170. §, Vékás 2013. 158., Kisfaludi 2014b. 383.

${ }^{478}$ Komáromi - Pázmándi 214-215.

${ }^{479}$ Sárközy 2014. 117.

${ }^{480}$ Uo., lásd még Barta 2016b. 169.

${ }^{481}$ Halász 20-21.
} 
értelmezésével arra a következtetésre lehet jutni, hogy a forgalmi érték örökös részére történő megfizetésére is sort kell keríteni ez alatt a 30 nap alatt. ${ }^{482}$

Sajátos megoldás született a gyakorlatban, miszerint egy gazdasági társaság akképp oldotta meg a jogutódlás problémájának elkerülését, hogy a természetes személy tagok számára életbiztosítást kötött, és az életbiztosítás összegéből váltják meg az üzletrészt. ${ }^{483}$

Jogszabályba ütköző a társasági szerződés azon rendelkezése, miszerint ha a tag örökös nélkül hal meg, a többi tag jogosult az üzletrész megváltására ${ }^{484}$ anélkül, hogy megfelelő mértékü megváltásra ne lennének kötelezettek. Nem fordulhat elő az a helyzet, hogy egy természetes személy halála esetén ne lenne örökös, hiszen az állam szükségképpeni örökös. ${ }^{485}$

Az osztrák tőkeegyesítő társaságoknál az üzletrész és a részvény alapvetően örökölhető. A GmbHG 75. §-a alapján minden tag csak egy üzletrésszel rendelkezik, majd a követező §-ban lakonikusan kijelenti, miszerint az üzletrész örökölhető. ${ }^{486}$ (Teszi ezt akképp, hogy ebben a bekezdésben kimondja, hogy az üzletrész át is ruházható, ${ }^{487}$ majd a 76 . $\S$ folytatása az üzletrész átruházásával kapcsolatos rendelkezéseket tartalmaz.) E törvény 79. § alapján pedig az üzletrész felosztására kerülhet sor, az örökösök között az örökrészüknek megfelelően, de a társasági szerződés elöírhatja az üzletrész feloszthatatlanságát, azaz az örökösök az üzletrészt együttesen szerzik meg. ${ }^{488}$ Közös tulajdonú üzletrész esetén az egyes tulajdoni hányadok szintén örökölhetőek. ${ }^{489} \mathrm{~A}$ tag halálával nem szünik meg tehát az üzletrész, ${ }^{490}$ továbbá az üzletrész jogutódlását általánosságban társasági szerződésbeli szabályozás útján nem lehet kizárni vagy korlátozni a személyegyesítő társaságokhoz képest, ${ }^{491}$ és nem lehet közvetlenül egy társasági jogi utódlási szabályozást bevezetni, de a társasági szerződésben megállapított, az életben maradt tagok javára szóló megváltási jogra (Aufgriffsrecht) irányuló rendelkezések érvényesek lehetnek. Egy ilyen klauzula

\footnotetext{
${ }^{482}$ Barta 2016b. 168-169.

${ }^{483}$ Kovács Krisztián megbízott oktató, doktorandusz hozzászólása a Magánjogot Oktatók Egyesületének nyolcadik éves rendes konferenciáján a Származtatott alapítás - származékos tulajdonszerzés címmel tartott előadásomhoz (Budapest, 2017. május 26.).

${ }^{484}$ LB Cgf. VII. 30.241/2001/2., idézi: Papp 2011b. 412.

${ }^{485}$ Ptk. 7:74. §

${ }^{486}$ Brünner - Pasrucker 95.

${ }^{487} \mathrm{GmbHG} \S 76$. (1) Die Geschäftsanteile sind übertragbar und vererblich.

${ }^{488}$ Brünner - Pasrucker 115., Kalss - Probst 668-669.

${ }^{489}$ Kalss - Probst 196.

${ }^{490}$ OGH 6 Ob 63/10y. Idézi Rauter Rdnr. 231.

${ }^{491}$ Brünner - Pasrucker 115.
} 
következménye az örökösök abbéli kötelezettsége, hogy az üzletrészt a többi üzlettársnak vagy a tagok egy meghatározott csoportjának, így a család valamely ágának fel kell kínálniuk, akiknek joguk van a magukhoz váltáshoz, ezzel a társasági vagyoni viszonyokban a számukra kedvező családi eloszlást biztosítani. ${ }^{492} \mathrm{Ha}$ az örökös a GmbH tagjává válik, őt is be kell jegyeztetni a cégnyilvántartásba. ${ }^{493}$

\subsubsection{Közös tulajdonú üzletrész keletkezése}

A hatályos öröklési jogi szabályok alapján, ha az örökhagyónak több gyermeke volt, a hagyatékból fejenként egyenlő részben örökölnek, ${ }^{494}$ valamint többen örökölnek akkor is, ha a túlélő házastárs gyermek vagy az örökhagyó szülei mellett örököl. ${ }^{495}$ Egy üzletrésznek több tulajdonosa is lehet. Közös tulajdonú üzletrész a társaság müködése során is létrejöhet, például az üzletrész örökléssel száll át a jogutódokra, ${ }^{496}$ amelynek egyébként a gyakorlatban nagy jelentősége van. ${ }^{497}$ Törvényes öröklés mellett természetesen végintézkedés révén is létre lehet hozni mind közös tulajdont, mind pedig azon haszonélvezetet. ${ }^{498}$ Azonban nem csupán öröklés esetén keletkezhet közös tulajdonú üzletrész, hanem abban az esetben is, ha többen vesznek meg egy üzletrészhányadot, vagy a társasági szerződésben megállapított, tag által kötelezően fizetendő vagyoni, illetve nem vagyoni hozzájárulást (apportot) egy törzsbetét vonatkozásában többen teljesítik. A közös tulajdonú üzletrész tulajdonosai a társasággal szemben egy tagnak számítanak; jogaikat csak közös képviselőjük útján gyakorolhatják, és a tagot terhelő kötelezettségekért egyetemlegesen felelnek. ${ }^{499}$ A képviselő személyét illetően a résztulajdonosok szabad belátásuk szerint dönthettek, az általuk legalkalmasabbnak ítélt személyt jelölték ki. A Gt. nem rendelkezett arról, hogy a képviselőnek mindenképpen a tagok közül kellene kikerülnie. A közös tulajdonú üzletrész korábbi szabályozásával ${ }^{500}$ összefüggésben kialakult bírói gyakorlat szerint ahogy az a jelen döntésben is megjelent -, „nincs akadálya annak, hogy az üzletrész állagörökösei az üzletrész haszonélvezeti jogát öröklő túlélő házastársat válasszák a

\footnotetext{
${ }^{492}$ Kalss - Probst 669. További kérdésekre hívja fel a figyelmet Graisy 8-46.

493 OGH 15. 2. 2000, 5 Ob 110/99h, idézi Schopper 1369. A Manz Verlag vonatkozásában sikeres jogutódlásról, illetve vagyonfelosztásról ír Kalss 2015a. 51-52.

${ }^{494}$ Ptk. 7:55. § (2) bek.

${ }^{495}$ Ptk. 7:58. §, 7:60. §

496 Pázmándi 2014b. 608.; Sárközy 2014. 108.

${ }^{497}$ Török T. 2015. 217.

${ }^{498}$ Vö. Villám 37.

${ }^{499}$ Ptk. 3:165. § (1) bek.

${ }^{500}$ Gt. 122 .
} 
közös tulajdonú üzletrész képviselőjének, aki - mint a tagsági jogok gyakorlására elsődlegesen jogosult érdekelt - nem tekinthető a közös tulajdonú üzletrész tekintetében kívülállónak."

A Ptk. e körben változást hozott, ugyanis a megújult szabályozás szerint a közös tulajdonú üzletrész jogosultjai maguk közül kell, hogy válasszanak képviselőt a tulajdoni hányaduk szerinti szavazati jog gyakorlásával. ${ }^{502} \mathrm{Ha}$ a tagok eltérően nem rendelkeznek, a tulajdonostársak szótöbbséggel határoznak a közös tulajdont érintő kérdésekben, amely szavazati jog a tulajdoni hányaduk arányában illeti meg őket, ${ }^{503}$ ekképp választhatnak képviselőt is; a képviselő személyének megválasztása nem esik azon körbe, amelyhez egyhangú határozat lenne szükséges. ${ }^{504}$ Szükséges utalni arra, nem egységes a jogirodalom annak megítélésében, hogy közös képviselő csak a közös üzletrész résztulajdonosai közül kerülhet ki, vagy a tulajdonosok választhatnak nem tulajdonostárs képviselőt is.

Meg kell azonban jegyezni, hogy a közös tulajdonú üzletrész képviselöjét el kell határolni attól a személytől, aki eseti meghatalmazással helyettesíti ezt a képviselőt, példának okáért azért, mert az egyébként a közös tulajdonú üzletrész képviselőjének minősülő személy külföldön van, így nem képes gyakorolni az őt megillető jogokat. A meghatalmazott személy csak olyan körben válik jogosulttá, amilyen körben öt meghatalmazta a képviselő. Ezt a személyt eseti érintettsége folytán nem is fogják bejegyezni a cégjegyzékbe, valamint a meghatalmazás jogszerüségét vizsgálni kell eljárása folyamán.

Dzsula Marianna szerint a cégbíróságok gyakorlata feltehetően megengedő lesz a képviselő személyének kiválasztásában, egyes szakmai grémiumok előzetes állásfoglalása alapján a Ptk. 3:165. § (1) bekezdése ebben a kérdésben diszpozitív. ${ }^{505} \mathrm{~A}$ jelzetteknek megfelelően ez azonban alapvetően dologi jogi kérdés azzal a specialitással, hogy a társasági jogi joganyagban megtalálható a dologi jogi könyvbeli közös tulajdonra vonatkozó szabály. A diszpozitivitás egyik okaként egy sajátos példát említ a szerző, ami szerint, ha a közös tulajdonú üzletrész minden jogosultja külföldön él, célszerü képviselöként egy belföldi személyt kijelölni. Ezt az álláspontot védhetőnek tartom természetesen belföldi tagok esetén is, e személynek azonban érdemes

\footnotetext{
${ }^{501}$ ÍH 2009. 130., Papp 2011b. 405.

502 Ptk. 3:165. $\S(2)$ bek.

${ }^{503}$ Ptk. 5:78. § (1) bek.

${ }^{504}$ Ptk. 5:78. § (2) bek.

${ }^{505}$ Lásd Dzsula 2014b. 4-8.; Komáromi - Pázmándi 208.
} 
valamilyen módon a társasághoz, illetve a közös tulajdonú üzletrésszel rendelkező tagokhoz kötődnie, miután a közös képviselő tagsági jogot gyakorol; lehet, de nem célszerü, hogy ezt a feladatot kívülálló személy lássa el. ${ }^{506}$ Hasonló helyzet nem csak öröklés esetén valósulhat meg, elegendő csupán valamilyen jogi személy tagságára gondolni, amely esetén mindenféleképp kell kézbesítési megbízott. A példákon kívül megalapozottabb lehet ez a jogalkalmazási álláspont, ha annak indokolása az alábbiakat is tartalmazná: Csehi Zoltán emeli ki, hogy a Ptk. 3:1. § (4)-(5) bekezdéseiben foglalt, a jogi személy alapvető ismérveit tartalmazó szabályokra tekintettel kell kezelni a Ptk. 3:4. §-beli „diszpozitivitási tesztet”. A teszt első lépését tekintve, nem tag-tag közötti kérdésről van szó, mivel a közös tulajdonú üzletrész jogosultjai a társasággal szemben egy tagnak minősülnek, ez a viszony a tag és jogi személy közötti viszonyhoz illik. A törvény nem tiltja az eltérést; se a hitelezőket, se a munkavállalókat nem érinti a közös képviselö személye, a tagok kisebbségét érintheti, amennyiben a közös tulajdonú üzletrész egy jelentős hányadot képvisel, és azt egy másik, szintén nagyobb hányaddal bíró tag képviseli. Ez alapvetően nem okozhat nyilvánvaló jogsérelmet, mivel a kisebbségvédelmi eszközök hatékonyan igénybe vehetőek, gondoljunk például a meghozott határozat bírói felülvizsgálatának kezdeményezésére. A teszt végső lépcsőjét vizsgálva a közös képviselő személyének kiválasztása a törvényességi felügyeletet sem tudja akadályozni, annyi az érintett személyek kötelezettsége, hogy valakit válasszanak ki. Ezeket az elemeket figyelembe véve állapítható meg, hogy a közös képviselő személyére vonatkozó szabály nem minősülne olyan szabálynak, amitől ha eltérnénk, a korlátolt felelősségü társaság már nem minősülne korlátolt felelősségü társaságnak, és Csehi Zoltán elemzése alapján nem fogható fel a törvényben nevesített típusjegyként sem. ${ }^{507}$ Ennek magyarázata az, hogy a társaság ebbéli minőségét nem változtatja meg az, ha a közös tulajdonú üzletrész képviselöje nem a tagok közül kerül ki. A haszonélvezeti jog jogosultja és az örökös között mindazonáltal keletkezhetnek feszültségek, amelyek valamely vagy akár mindkét fél számára megnehezítik az őket megillető jogaik megfelelő gyakorlását, ekkor ezt a helyzetet meg kell szüntetni. Mindezek miatt álláspontunk szerint a hivatkozott tételek továbbra is alkalmazhatóak, ami azt jelenti, hogy haszonélvezettel terhelt közös tulajdonú üzletrész képviselöjeként ki lehet jelölni a haszonélvezőt. A Ptk. előírása értelmezhető akképp, hogy a tulajdonostársak érdekei megfelelő módon legyenek képviselve a képviselő

\footnotetext{
${ }^{506}$ Dzsula 2014b. 4-8.; Dzsula 2014c. 990.

${ }^{507}$ Vö. Csehi 2016. [6]
} 
személyének maguk közüli kiválasztásával, azonban érdemes megjegyezni, közöttük is fennállhat vita, a kisebbségben maradó tagnak a szótöbbséggel hozott határozatot bíróság előtt meg kell támadnia. ${ }^{508}$

A közös tulajdonú üzletrész tulajdonosai, azaz példánkban az örökhagyó gyermekei egy tagnak számítanak, jogaikat a kijelölt képviselő útján gyakorolják, a tagot terhelő kötelezettségekért pedig egyetemlegesen felelősek. „A haszonélvezeti joggal terhelt üzletrész tulajdonjogának részjogosítványai közül a tulajdonost csak a rendelkezési jog illeti (jogosult tehát az üzletrész elidegenítésére), de a birtoklás, használat és a hasznok szedésének joga a haszonélvezőé, aki ily módon - a likvidációs hányadhoz való jog kivételével - a vagyoni jellegü és a szervezeti tagsági jogok gyakorlására is elsődlegesen jogosult.”, ${ }^{\text {, }}$ A döntés ekként folytatja: „nincs akadálya annak, hogy az üzletrész állagörökösei az üzletrész haszonélvezeti jogát öröklő túlélő házastársat válasszák a közös tulajdonú üzletrész képviselőjének, aki - mint a tagsági jogok gyakorlására elsődlegesen jogosult érdekelt - nem tekinthető a közös tulajdonú üzletrész tekintetében kívülállónak." ${ }^{510}$ A fentieknek megfelelően a bírói döntés e része a diszpozitivitási szabály nélkül már nem lenne alkalmazható a megváltozott jogszabályi környezet miatt, a többi része viszont igen: a közös tulajdonú üzletrészen állhat fenn haszonélvezet.

A Ptk. hatályba lépésével eltérően alakul a haszonélvezeti jog megváltása, mivel az özvegyet fő szabály szerint az örökhagyóval közösen lakott lakáson és a hozzá tartozó berendezési és felszerelési tárgyakon illeti meg a haszonélvezeti jog, ${ }^{511}$ egyértelmüen ezen a körön kívül esik az üzletrész, ezért egy gyermekrésznyi illeti meg ebből. ${ }^{512}$ Abban az esetben lehet a régi Ptk.-beli helyzetet megteremteni, ha az örökösök és köztük az özvegy érdekeinek ez jobban megfelel, amennyiben osztályos egyezséggel a házastársnak a gyermekrész helyett az egész hagyatékra kiterjedő holtig tartó haszonélvezeti jogot biztosítanak, ${ }^{513}$ majd az özvegy a haszonélvezet megváltását igényli. ${ }^{514}$ Továbbá ilyen jogi megoldáshoz lehet folyamodni például akkor, ha az özvegy és a leszármazók közötti korábbi megfelelő családi kapcsolat megromlott, és az

\footnotetext{
${ }^{508}$ Ptk. 5:79. §

509 ÍH 2009. 130.

510 ÍH 2009. 130.

${ }^{511}$ Ptk. 7:58. $\S$ (1) bek. a) pont

${ }^{512}$ Ptk. 7:58. § (1) bek. b) pont

${ }^{513}$ Ptk. 7:58. § (3) bek.

${ }^{514}$ Ptk. 7:59. §
} 
ebből támadt társaságon belüli problémák megoldását ilyen módon kívánják rendezni. (Lásd bövebben a 4.3.2.4. pontot.)

„Ha az üzletrészt öröklő több örökös közül egyesek tagok akarnak lenni, mások viszont nem, az örökösöknek - álláspontom szerint - osztályos egyezségben kell az egymás közötti - az üzletrészre is kiterjedő - jogviszonyt rendezniük, s ettől függően válnak egyes örökösök a társaság tagjává, mások pedig nem. Ha még ez esetben is több örökös válik taggá, reájuk is az elöbbiekben már tárgyalt az az eset, jogi helyzet következik be, hogy közös üzletrész-tulajdonosokká válnak."

Jelentős jogértelmezési kérdés ebben a körben az, miképp értelmezzük az egyszemélyes korlátolt felelösségü társaság mibenlétét: állhat-e az egyetlen üzletrész közös tulajdonban? A Ptk. sem oldotta fel teljes mértékben a bizonytalanságot a fogalmat illetően, abba akár azt is bele lehet érteni, hogy - ellentétben a társaság jelzőjének („egyszemélyes”) nyelvtani értelmezésével - állhat közös tulajdonban az ilyen üzletrész (valamennyi üzletrészt ugyanaz a tag szerzi meg ${ }^{516}$ - egy üzletrésznek több jogosultja is lehet, ezek a személyek a társasággal szemben egy tagnak számítanak). ${ }^{517}$ A kialakult bírói gyakorlat következetesen amellett foglal állást, hogy nem állhat egyszemélyes kft üzletrésze közös tulajdonban, egyrészt ennek a gyakorlatnak az elismerésére, másrészt a társaság elnevezésének pontos értelmezésére tekintettel egyetértek Barta Judittal abban, hogy a jogalkotónak - figyelemmel a Harmadik Könyv szabályozási módszerére is - érdemes lenne egyértelműen, semmisséget megállapító, eltérést nem engedő szabályként kimondani az ítélkezésben kifejlődött tételt. ${ }^{518}$

\subsubsection{Az üzletrész felosztása}

Az üzletrész felosztása olyan sajátos intézmény, amely a törzstőke érintetlenül hagyása mellett - figyelemmel a létesítő okirat rendelkezésére - strukturális változást képes előidézni, mely a gazdasági társaság belső működésére kihatással lehet. ${ }^{519}$ Habár megjelent az újabb bírói gyakorlatban, ${ }^{520}$ miszerint az üzletrész felosztásával növekedni

\footnotetext{
515 Tarr 277.

${ }^{516}$ Ptk. 3:208. § (2) bek.

${ }^{517}$ Ptk. 3:165. § (1) bek.

${ }^{518}$ Barta 2012. 23-27.

${ }^{519}$ Farkas 337-338.

${ }^{520}$ ÍH 2017. 30. I.
} 
fog a társaságon belül az üzletrészek száma, ez nem feltétlenül fog megvalósulni, ${ }^{521}$ például abban az esetben, amikor valamely örökös már korábban is a társaság tagja lehetett, így már rendelkezett üzletrésszel.

A Gt. lehetőséget adott az üzletrész felosztásának tilalmazására. ${ }^{522}$ Fontos azt kiemelni, hogy felosztásra csak akkor van lehetőség öröklés jogcímén, ha még nem kerültek az örökösök átvezetésre sem a tagjegyzéken, sem a cégbíróság nem jegyezte be a változást, ellenkező esetben már nem beszélhetünk felosztásról. Az alábbi esetekben keletkezik közös tulajdonú üzletrész: a taggyülés nem járul hozzá az üzletrész felosztásához, a társasági szerződés a felosztást eleve kizárta, illetve ha a kialakítandó üzletrész nem tesz eleget a törzsbetét-kialakítás minimális követelményeinek. Az örökösök a Gt. 9. § (2) bekezdése alapján alkalmazandó régi Ptk. szerinti közös tulajdon szabályai alapján szereztek tulajdont az üzletrész felett. ${ }^{523} \mathrm{~A}$ kft. és a tulajdonostársak viszonyára a Gt. szabályai voltak az irányadóak. ${ }^{524}$

Ahogy azt a Gt. is megengedte, a Ptk. szabályozása sem zárja ki azt, hogy ugyanaz a tag a kft.-ben egy önálló üzletrész tulajdonosa legyen, és egy további üzletrészben tulajdonosi hányadot szerezzen. ${ }^{525}$ A Ptk. 3:173. § a Gt. 130. §-hoz hasonlóan taxatív felsorolást ad a felosztás eseteit illetően, némileg átfogalmazva, miszerint az üzletrész átruházás, jogi személy tag szétválása folytán az üzletrésze tekintetében bekövetkezett jogutódlás, öröklés, házastársi közös vagyon megosztása, új jogosult hiányában a tag jogutód nélküli megszünése esetén osztható fel. Az üzletrész felosztása, valamint az ahhoz való taggyülési hozzájárulás megadása utólagos jellegű, az erre vonatkozó döntést meg kell, hogy előzze az öröklés, jogutódlás, átruházás esetén a jogügylet, amely közös tulajdont hoz létre az üzletrészen. ${ }^{526}$

Az elöbb kifejtettek szerint öröklés esetén egy üzletrész felett több örökös is szerezhet tulajdont. Ez a tulajdonközösség az örököstársak érdekeinek nem mindig megfelelő állapot, ${ }^{527}$ ezért is engedi meg az üzletrész felosztását a Ptk., ahogy a Gt. is tette. A Gt. szerint a felosztáshoz a taggyülésnek is hozzá kellett járulnia, miután a felosztás érintheti a társaság tagi összetételét, de megengedte azt, hogy a társasági

\footnotetext{
${ }^{521}$ Vö. Papp 2011b. 413.

${ }^{522}$ Gt. $130 . \S(3)$ bek.

${ }^{523}$ A Gt. 114. § (5) bekezdése szerint minden tagnak egy törzsbetéte volt; egy törzsbetétnek azonban - a közös tulajdon szabályai szerint - több tulajdonosa is lehetett. A közös tulajdonra nem állapított meg a Gt. külön rendelkezéseket, ezért kellet a régi Ptk.-t is figyelembe venni.

${ }^{524}$ Papp 2011b. 405.

525 ÍH 2017. 30. II

526 ÍH 2014. 157.

${ }^{527}$ Barta 2016b. 171-172.
} 
szerződés eltérően rendelkezzen. ${ }^{528} \mathrm{Ez}$ az üzletrész-felosztás sem lehetett azonban korlátok nélküli: a 130. § (2) bekezdése visszautalt a törzsbetét legkisebb mértékére irányadó rendelkezésekre, azaz a 114. § (4) bekezdésére, következésképpen a felosztással kialakult üzletrész alapjául szolgáló törzsbetét mértéke nem lehetett kevesebb százezer forintnál, forintban kifejezettnek és tízezerrel maradék nélkül oszthatónak kell lennie. A már tárgyalt ÍH 2009. 130. eseti döntésben is probléma adódott abból, hogy a cégbíróság nem megfelelően oldotta meg a bejegyzést, a 120 ezer Ft-os üzletrész nem osztható kettő egyenlő részre úgy, hogy az új üzletrészekre igazak legyenek a fenti kritériumok. Ehhez képest a Ptk. kifejezett kógens rendelkezése nem engedi meg egyrészt, hogy más esetet is a felosztás alá soroljanak, másrészt a taggyülés hozzájárulása mindenképpen szükséges a felosztáshoz. Főszabályként az érdekelt üzletrész tulajdonosok, vagy az érintett felek, örökösök, házastárs bejelentése alapján taggyülés összehívásáról kell gondoskodni, ami az ügyvezető kötelessége. ${ }^{529}$ Problémát jelenthet kifejezetten egyszemélyes korlátolt felelősségü társaságnál (bár ez többszemélyesnél is fennállhat), ha a tag egyben ügyvezető is volt. A Hetv. 32. § (2) bekezdése szerint ügygondnok rendelhető ki. Ahogy azt a hagyatéki eljárásról szóló kommentár írja, ${ }^{530}$ nem a vezető tisztségviselet ellátására rendelik ki az ügygondnokot, hanem például annak érdekében, hogy az ő szavazatával megválasszák az új ügyvezetőt. Az örökösök így már kérhetik az új ügyvezetőtől a tagjegyzékbe való bejegyzésüket. ${ }^{531}$

Kisfaludi András állapította meg: „az örököstársak közötti közös tulajdonhoz hasonló helyzet „természetbeni megosztással” (azaz üzletrész-felosztással) nem szüntethető meg, nem kizárt azonban az üzletrész megváltása valamelyik örököstárs által vagy az üzletrész egységként való átruházása - az erre vonatkozó speciális szabályok betartásával."

Az üzletrészek felosztásának problematikája, az értelmezés ellentmondásainak kitünő példájának minősül a BDT 2003. 767. ${ }^{533}$ számon közzétett eseti döntés, mely a Ptk. hatálya alatt is irányadó. A közös tulajdonú üzletrész nem esik teljes mértékben a dologi jogi értelemben vett közös tulajdon fogalmával egy tekintet alá, speciális jogközösségnek minősül, melyre a dologi jellegü tulajdonközösség szabályait

\footnotetext{
${ }^{528}$ Papp 2011b. 414.

${ }^{529}$ Pázmándi 2014b. 641.

${ }^{530}$ Anka 2014a. 101.

${ }^{531}$ Ptk. 3:170. § (1) bek.

532 Kisfaludi 1991. 154

533 A döntésben hivatkozott Gt. szabályok még az 1997. évi CXLIV. törvényre utaltak, de azok tartalma az ügy lényegének szempontjából a 2006. évi IV. törvényben, illetve a 2013. évi V. törvényben nem
} változtak. 
megfelelően kell alkalmazni, ami egyaránt vonatkozik a belső és külső viszonyaira. A megfelelő alkalmazás azt is jelenti, hogy a közös tulajdonú üzletrész kialakítása, megszerzése, megszüntetése elsősorban a Gt. szabályai szerint mehetett végbe, ami egyértelmüen meghatározta kógens módon és egyértelmüen. A közös tulajdon természetbeni megosztása nemcsak azért nem tartozik a társasági jog hatókörébe, mert nem a Ptk. szerinti dologról van szó, hanem ennek bírói úton történő megvalósítása a bíróság részéről a társaság életébe való meg nem engedett beavatkozást jelentené. Egy üzletrész helyett kettő vagy több kialakítása eleve szerződésmódosítást igényel. A társasági szerződésnek bírósági határozattal történő módosításra nincs jogszabályi lehetőség, a szerződésmódosítás szabályait a Gt. ugyanis egyértelmüen meghatározta. A Gt. azonban pontosan körülírta a közös tulajdonú üzletrész megszüntetését, annak eseteit, ezeket kógens jelleggel írja elö, attól eltérni nem lehet, ugyanígy tesz a Ptk. is. A közös tulajdont föszabály szerint természetben kell megosztani, ha ez nem lehetséges, vagy a természetbeni megosztás jelentős értékcsökkenéssel járna vagy meggátolná a rendeltetésszerü használatot, a közös tulajdon tárgyát értékesíteni kell, a vételárat pedig a tulajdonostársak között megfelelően kell felosztani. ${ }^{534}$ A korlátolt felelősségü társaságra vonatkozó törvényi szabályozás azonban nem teszi lehetővé az üzletrészen fennálló közös tulajdon természetbeni megosztását. Az ilyen megszüntetés a társaság életébe való meg nem engedett beavatkozást, a társasági szerződés módosítását jelentené, ${ }^{535}$ a taggyülési határozatot nem pótolhatja a bírósági ítélet. ${ }^{536}$

A Gt.-től eltérően a Ptk. az egyes üzletrészek mértékére csak annyit szab meg, hogy az nem lehet kevesebb százezer forintnál. ${ }^{537}$ Szükséges jelezni ugyanakkor, hogy ebben a jogirodalom és a joggyakorlat nem egységes, van olyan szakmai álláspont, mely szerint a százezer forintos minimum nem tartozik a törzsbetét szük értelemben vett fogalmához, így ez a kérdés a 3:4. § (2) bekezdése szerint a felek autonómiájába tartozik, azaz diszpozitív. ${ }^{538}$ Ezt azzal lehet indokolni, hogy a gazdasági társaság tagjai egymás közti, illetve társasághoz füződő viszonyról van szó, az eltérést nem tiltja a jogszabály, a jogi személy hitelezőjének, munkavállalójának, a tagok kisebbségének jogát nem sérti nyilvánvalóan, mert a törzstőke mértékének ettől meg kell felelnie a hárommillió forintos alsó küszöbnek, a belső elosztás irreleváns, továbbá nem

\footnotetext{
${ }^{534}$ Ptk. 5:84. § (1) - (2) bek.

${ }^{535}$ BDT 2016. 3462., BDT 2011. 2558.

${ }^{536}$ BDT 2016. 3462. [3]

${ }^{537}$ Ptk. 3:161. $\S$

${ }^{538}$ Dzsula 2014b. 4-8.; Dzsula 2014c. 990.; Komáromi - Pázmándi Kinga 218.
} 
akadályozza a törvényességi felügyeletet sem. Ehhez az állásponthoz képest nincs és nem is volt másik olyan gazdasági társaság a Ptk., valamint a korábban hatályos gazdasági társaságokra vonatkozó törvények szerint, amelyikben meg lenne határozva az egy tag által nyújtott vagyoni hozzájárulás minimális mértéke: a közkereseti és a betéti társaságnál magának a társaságnak a minimális vagyona sem kerül meghatározásra, így a tagok vagyoni hozzájárulását sem lehet megszabni. A részvénytársaságok alaptőkéjét kitevő részvények vonatkozásában a törvény csak azt mondja ki, hogy az alaptőkét meghatározott számú és névértékü részvény képezi, ${ }^{539}$ további kikötést nem tartalmaz. Meglátásom szerint a törzsbetétek e tulajdonsága olyan sajátos, jellegadó ismérv, amelytől nem lehet eltérni, az ugyanis a típuskényszer sérelmét jelentené. ${ }^{540}$

Mindezek után tekintsük át az eljárás menetét, miképp járjon a korlátolt felelősségü társaság abban az esetben, ha valamely tagja meghalt, neki több örököse van, akik az üzletrész felosztását kérik. Miután a taggyülés hozzájárulása szükséges az üzletrész felosztásához, ezért azt össze kell hívni. A határozatképesség megállapításánál nem veszik figyelembe a felosztással érintett, örökölt üzletrészt, a határozatot ennek figyelembe vételével kell meghozni. ${ }^{541}$ Az öröklés következtében közös tulajdonba került üzletrész vonatkozásában az örökösök kérelmezik az ügyvezetőtől a változások átvezetését a tagjegyzéken, aki ennek eleget kell, hogy tegyen, ha nincs olyan személy, aki az üzletrész megváltására lenne jogosult valamely tag halála esetén, vagy nem akar élni ezzel a jogával. Az üzletrész felosztásának lehetőségéről rendelkeznie kell a társasági szerződésnek, amely alapján kérhetik azt az örökösök, ezen túl az is szükséges, hogy a felosztás eredményeként létrejövő üzletrészek mértéke haladja meg egyenként a százezer forintot. ${ }^{542} \mathrm{Ha}$ a taggyülés megszavazza a felosztást, fel kell hívnia az ügyvezetőt, hogy a felosztás folyamán bekövetkezett változást vezesse át a tagjegyzéken. A taggá vált örökösöknek nyilatkozni kell, hogy a társasági szerződés rendelkezéseit magukra nézve kötelezőnek ismerik el, ezt csatolni is kell a cégbíróságnak, helyénvaló e nyilatkozat feltüntetése a taggyülési jegyzőkönyvben. Mindezek bejelentése a cégbíróság felé az ügyvezető feladata. ${ }^{543}$

\footnotetext{
${ }^{539}$ Ptk. 3:210. §

${ }^{540}$ Lásd még Sárközy 2015. 13.; Dzsula 2014c. 990.; Csehi 2016. [6]

${ }^{541}$ Ptk. 3:18. § (2) bek., 3:19. § (2) bek. f) pont

${ }^{542}$ Ptk. 3:161. § (1) bek.

${ }^{543}$ Ptk. 3:29. § (3) bek., vö. Gál 2015. 461-475.
} 


\subsubsection{Az üzletrészen fennálló özvegyi jog 544}

Az özvegyi jogra vonatkozó általános szabályokon túlmenően további kérdések is tisztázásra várnak. „Jogok esetében a birtoklás nyilván nem értelmezhető fogalom, hiszen az valamilyen dolog feletti hatalmat fejez ki, a használat és a hasznok szedésének joga azonban már azonosítható a jog gyakorlásával és a társasági tagsági jogok alapján járó hasznok elsajátításával." ${ }^{, 545}$ Kisfaludi András szerint miután a haszonélvező annak tudatában gyakorolja a tagsági jogokat, hogy ezek a jogok és az abból eredő hasznok őt csak korlátozott ideig (legfeljebb haláláig) illetik meg, a lehető legnagyobb hasznot szeretné magának biztosítani, ezért ezek alapján neki nem az az érdeke, hogy a társaságban hosszabb távon befektessenek, hanem a rövidtávú hasznossági szempontokat veszi figyelembe. ${ }^{546}$ Ehhez hozzá kell venni azt az esetet, ha az örökösök kiskorúak, és az életben maradt szülőjük a haszonélvező. A szülő a gyermek törvényes képviselője, aki jogosult a kiskorú vagyonát kezelni. ${ }^{547}$ Amennyiben a gyermek vagyonának kezelése tekintetében a gyermek érdekeit súlyosan sértő módon nem teljesíti kötelezettségét, a gyámhatóság indokolt esetben a Ptk. 4:159. §-ban foglalt intézkedéseket rendelheti el, e körben akár a vagyonkezelést rendszeres gyámhatósági felügyelet alá vonhatja vagy akár a szülő képviseleti jogát korlátozhatja, vagy megvonhatja, ebben az esetben eseti gyámot kell kirendelni. ${ }^{548}$ A Ptk. 5:149. § (1) bekezdése alapján a haszonélvezet jogának gyakorlása során a rendes gazdálkodás szabályai szerint kell eljárni. Jelen esetben ez a szabály azt jelenti, hogy a tagi érdekeken túlmenően figyelemmel kell lenni a társaság müködésére is. „Nyilván beleütközne ebbe a szabályba az, ha a haszonélvező a társaság vagyoni helyzetét, jövőbeni üzleti pozícióit romboló döntéseket hozna csak azért, hogy saját számára pillanatnyi előnyöket biztosítson." ${ }^{, 549}$ A Ptk. hatálybalépése előtt megnyílt öröklési ügyekben támadó jogviták eldöntésére indokolt a kérdés rendezése. A haszonélvezet (pontosabban a hagyományos özvegyi jog) szabályai Ptk.-beli megváltoztatásának egyik fö indokaként bizonyos vagyontárgyak (így készpénz, bankbetét, vagy éppen az üzletrész, értékpapír) hagyatékokban való egyre jelentősebb elterjedése került megjelölésre, amelyekre az állagöröklés és a haszonélvezeti jog öröklésének

\footnotetext{
${ }^{544}$ Lásd még Kovács G. 97.

${ }^{545}$ Kisfaludi - Szabó 945.

${ }^{546}$ Kisfaludi - Szabó 945., vö. Besenyei 2009. 36.

${ }^{547}$ Ptk. 4:155. § (1) bek.

${ }^{548}$ Ptk. 4:163. § (2) bek.

${ }^{549}$ Kisfaludi - Szabó 946.
} 
párhuzamos elismerése gyakorlati szempontokból nem volt célszerü, ${ }^{550}$ ezért a korábbiakhoz képest az ezekben a vagyontárgyakban való állagöröklés mellett döntött a jogalkotó. Ezek az indokok a törvényes öröklésre igazak, a végintézkedésre vonatkozó szabályok nem tiltják meg azt, hogy az örökhagyó haszonélvezetet alapítson a hagyaték bármely tárgyán.

A már többször hivatkozott ÍH 2009. 130. számon közzétett ítélőtáblai döntés szerint a haszonélvezeti joggal terhelt üzletrész tulajdonjogának részjogosítványai közül a tulajdonost csak a rendelkezési jog illeti, a birtoklás, használat és a hasznok szedésének joga a haszonélvezőé, aki ily módon a vagyoni jellegü és a szervezeti tagsági jogok gyakorlására is elsődlegesen jogosult. Mindezek azt jelentik, hogy az örökhagyó halálával, a haszonélvezet keletkezésével a tulajdonosi triász különválik, csak a rendelkezési jog az állagörökösé, a többi a haszonélvezet szabályai szerint a haszonélvezet jogosultját illeti meg. A Ptk. 5:147. § (1) bekezdése csak a dolgok vonatkozásában szabályozza a haszonélvezetet, de ezt a Ptk. 5:156. § (1) bekezdése kiterjeszti a kamatozó vagy más hasznot hajtó jog haszonélvezetére, az üzletrész pedig az utóbbi kategória alá tartozik. A haszonélvezet általános szabályait erre a kontextusra helyezve az állagörökösöket csak annyiban illeti meg a birtoklás, használat, hasznok szedésének joga (vagyis a tagsági jogok, például a szavazás joga), amennyiben azt a haszonélvező nem gyakorolja. ${ }^{551552}$

A szavazati jog a tagsági jogok közül az egyik legjelentősebb jogosítvány, amivel akár jelentősen is befolyásolni lehet a gazdasági társaság müködését a szavazati arányok és a társaságban fennálló erőviszonyok alapján. Ezért nem másodlagos kérdés az, hogy kit illessen meg ez a jog: az állagörököst vagy az özvegyi jog jogosultját, a haszonélvezőt. „Ha a szavazati jog a haszonélvezőt illeti, s a szavazati jogával oly módon él, hogy ezzel a rendes gazdálkodás szabályait sérti, akkor is megszületett a társasági határozat, amit utóbb aligha lehet megkérdőjelezni azon az alapon, hogy az állagörökös és a haszonélvező közötti vitában jóval később a bíróság az állagörökösnek igazat adva megállapítja, hogy a haszonélvező megsértette a rendes gazdálkodás szabályait." ${ }^{553}$ Folytatva ezt a gondolatmenetet, a Ptk. 5:152. § (2) bekezdése szerint először az állagörökösnek tiltakoznia kell a haszonélvező tevékenysége ellen, ennek eredménytelensége esetén követelhet biztosítékot, ha pedig a haszonélvező nem ad

\footnotetext{
${ }^{550}$ Vékás - Weiss 2451.

${ }^{551}$ Ptk. 5:152. § (5) bek.

${ }_{553}^{55}$ Besenyei 2004. 505-506.

${ }^{553}$ Uo.
} 
biztosítékot, a bíróság a tulajdonos kérelmére a haszonélvezeti jog gyakorlását biztosíték adásáig felfüggesztheti. ${ }^{554}$ Ezzel ,,az állagörökös meg tudja akadályozni azt, hogy a haszonélvező huzamosan és véglegesen a társaság és a társaság tulajdonosai érdekeit sértő módon gyakorolja az üzletrészből eredő jogokat."

Amennyiben a haszonélvezőnek csak az osztalékhoz lenne jogosultsága, akkor a tag valóban abban lenne érdekelt, hogy a haszonélvezeti jog fennállása alatt semmilyen haszon kifizetésére ne kerüljön sor. ${ }^{556}$ De vannak olyan élethelyzetek is, amikor nincs ellentét a haszonélvező és az örökösök között, ideértve pl. a kiskorú tag esetét, amikor a szülő a gyermek érdekeit szem előtt tartva jár el a társaság ügyében. A pontos útmutatás hiányára hívta fel a figyelmet Besenyei Lajos is. ${ }^{557}$ A haszonélvezeti joggal terhelt üzletrészt is el lehet idegeníteni, a Ptk. 5:147. § (3) bekezdése alapján a tulajdonos személyének változása nem érinti a haszonélvezeti jog fennállását. Minderre tekintettel logikus következtetés lenne az, ha a haszonélvezeti jogot fel lehetne tüntetni a cégjegyzékben annak érdekében, hogy az üzletrész következő lehetséges megszerzője közhiteles forrásból szerezzen tudomást az üzletrészt érintő minden teherről. A Ctv. 24 31/A. § taxatív felsorolást ad a cégjegyzék kötelező adatairól, amiben nem szerepel az üzletrészen fennálló haszonélvezet feltüntetésének se kötelezettsége, sem annak lehetősége. „Mivel azonban a tagjegyzéket a tagváltozás bejegyzésének kérelmezésekor be kell nyújtani a cégbírósághoz, e cégiraton keresztül a nyilvánosság számára is megismerhető a haszonélvezeti jog fennállása,"558 amennyiben azon megfelelően feltüntetésre került. Megfontolásra lenne érdemes a társasági részesedésen fennálló haszonélvezeti jog cégjegyzékbe való bejegyzése is az üzletrészen fennálló zálogjog 559 mintájára.

A szavazati joggal az osztalékhoz való jog kapcsolatba kerül: az üzletrészen fennálló haszonélvezeti jog az üzletrész hasznainak szedését jelenti, de nem szabad megfeledkezni arról a szabályról, amely szerint az osztalék csak akkor jár, ha a taggyülés a nyereség felosztásáról ilyen határozatot hozott. ${ }^{560}$ A további tagsági jogokat, pl. taggyülésen való részvétel, kérdésfeltevés, indítványtétel joga, illetően is az jegyezhető meg, azok gyakorlására a haszonélvező jogosult, ha az még belefér a

\footnotetext{
${ }^{554}$ Ptk. 5:152. § (3) bek.

${ }^{555}$ Kisfaludi - Szabó 946.

${ }^{556} \mathrm{Uo}$

${ }^{557}$ Besenyei 2009. 36.; Besenyei 2004. 503.

${ }^{558}$ Kisfaludi - Szabó 947.

${ }^{559}$ Ctv. 27. § (3) bek. c) pont

${ }^{560}$ Ptk. 3:185. §, Koday 9.
} 
haszonélvezet szabályaiba, azaz nincs összefüggésben a tulajdonost megillető rendelkezési joggal. Az üzletrészek haszonélvezete kapcsán is igaz az a szabály, miszerint a haszonélvezeti jog fennállása alatt a tulajdonos a birtoklás, a használat és a hasznok szedésének jogát annyiban gyakorolhatja, amennyiben a haszonélvező e jogokkal nem él. ${ }^{561}$ A haszonélvező jól felfogott érdeke, hogy ezekkel a jogokkal éljen. $\mathrm{Az}$ üzletrész tulajdonosa élhet ellenőrzési jogával, és biztosítékot kérhet a haszonélvezőtől, ha a haszonélvező a dolgot nem rendeltetésszerűen használja, ${ }^{562}$ tehát amennyiben a haszonélvező nem él a tagsági jogokkal, amelyekkel élhet.

$\mathrm{Az}$ ügyvezető javaslatára, amennyiben a társaságnál felügyelőbizottság müködik, ennek jóváhagyásával, a taggyülés osztalékelőleg fizetéséről is dönthet két, egymást követő beszámoló elfogadása közötti időszakban, ha közbenső mérleg alapján megállapítható, hogy a társaság osztalék fizetéséhez szükséges fedezettel rendelkezik, és ez a kifizetés nem haladja meg a közbenső mérlegben kimutatott adózott eredménnyel kiegészített szabad eredménytartalék összegét, valamint a társaság helyesbített saját tőkéje nem csökken a kifizetés folytán a törzstőke összege alá. ${ }^{563} \mathrm{Az}$ osztalékhoz hasonlóan ez is a haszonélvezőt illeti meg, szintén a haszonszedés kategóriájába tartozik. Amennyiben az osztalékelőleg kifizetését követően elkészülő éves beszámolóból az állapítható meg, hogy osztalékfizetésre nincs lehetőség, az osztalékelőleget vissza kell fizetni a tagoknak, ${ }^{564}$ ez a visszafizetési kötelezettség pedig független a tagok jó- vagy rosszhiszemüségétől. ${ }^{565}$ Tag alatt ilyen esetben a haszonélvezőt kell érteni, aki számára kifizetésre került az osztalékelőleg, neki is vissza kell fizetnie az osztalékelöleget, ha annak törvényi feltételei fennállnak.

Látszólag tehát okafogyottá teszi az üzletrészen fennálló haszonélvezettel kapcsolatos problémát a Ptk.-nak az a rendelkezése, ami szerint a 2014. márc. 15-e után bekövetkezett halálesetek vonatkozásában ${ }^{566}$ a házastársat a holtig tartó haszonélvezeti jog csupán az örökhagyóval közösen lakott lakáson és a hozzá tartozó berendezési és felszerelési tárgyakon illeti meg. ${ }^{567}$ Azaz ha a hagyaték tárgyai között társasági részesedés is van, úgy azon ezen időpont után nem állhat fenn törvény erejénél fogva özvegyi haszonélvezet, amely szabály természetesen nem érinti a korábban keletkezett

\footnotetext{
${ }^{561}$ Ptk. 5:152. $\S(5)$ bek.

${ }^{562}$ Ptk. 5:152. (1)-(2) bek.

${ }^{563}$ Ptk. 3:186. $\S(1)-(2)$ bek.

${ }^{564}$ Ptk. 3:186. $\$(3)$ bek.

${ }^{565}$ Kisfaludi 2014b. 397.; Pázmándi 2014b. 665., Komáromi - Pázmándi 229.

${ }^{566}$ Ptké. 57. § (1) bek.

${ }^{567}$ Ptk. 7:58. § (1) bek. a) pont
} 
ilyen jogviszonyokat, illetve a régi Ptk. hatálya alatt elhalt személyek tulajdonában álló üzletrészeken a túlélő házastárs számára keletkező özvegyi jogot. Ezzel együtt e körben ismét fel kell hívni a Ptk. 7:58. § (3) bekezdésében szabályozott osztályos egyezségre, amivel újra kialakulhat a régi Ptk. szerinti jogi helyzet. Ezen kívül az örökhagyó végrendeletet is tehet, amelyben eltérhet a törvényben foglaltaktól. Akármilyen módon keletkezik is az üzletrészen haszonélvezet, „bizonyos azonban, hogy a társaság tagjává csak az állagörökös válhat." 568

A korábbi jogi helyzet alapján gyakori eset volt, hogy valamelyik szülő halála esetén annak társasági részesedését a kiskorú gyermek örökölte meg a másik szülő haszonélvezeti jogával terhelten. Ebben az esetben a haszonélvező szülö, a törvényes képviselő és a kiskorú között esetlegesen fennálló érdekellentét miatt a kiskorú társaságbeli képviseletére a már említett eseti gondnok kirendelése vált szükségessé, a kirendelés tényét pedig a cégjegyzékbe is be kell jegyezni. ${ }^{569}$ Tovább bonyolította a helyzetet több kiskorú gyermek öröklése, mert ezek a gyermekek egy közös tulajdonú üzletrész tulajdonosai, ennek képviselője a túlélő házastárs lehetne, ha az üzletrészen fennálló haszonélvezete, vagy esetleges társasági tagsága miatt nem lenne érdekellentét közötte és a kiskorú(ak) között. A gyámhivatal a kiskorú gyermek vagyonának védelme érdekében a hagyatékátadó végzés kézbesítése után társasági részesedés öröklése esetén meggyőződik a cégnyilvántartáson történő átvezetésről is, ${ }^{570}$ hogy az üzletrészen fennálló tulajdonjogot bejegyezzék. Mindezek nem jelentik azt, hogy a haszonélvező szülő és a kiskorú gyermekek között feltétlen érdekellentét állna fenn, megfelelő családi kapcsolatok esetén nem okoz problémát ez a jogi állapot. „A kiskorút megillető üzletrész értékesítése olyankor fordul leginkább elö, amikor a kiskorú(ak) által megörökölt üzletrészt a társaság müködésének folyamatos és zökkenőmentes érdekében maga a társaság vásárolja meg. A kiskorú személyt a tulajdonát képező üzletrész tekintetében csak akkor képviselheti a szülő, ha egyik szülő sem érdekelt semmilyen szinten az adott gazdasági társaságban." ${ }^{, 571}$ E jogirodalmi állásponthoz képest elfogadható az, amennyiben a kiskorú gyermeknek csak az egyik szülőjével áll fenn érdekellentéte, akkor a másik szülő képviselhesse őt az üzletrésze vonatkozásában.

A hatályos szabályozás alapján a haszonélvezethez kapcsolható kérdés az osztályos egyezség a megváltásnál megjelentnél túlmenően. A Ptk. csak az osztályos

\footnotetext{
${ }^{568}$ Anka 1999. 39.

${ }^{569}$ Barzó 26.

${ }^{570}$ Uo.

571 Barzó 27-28.
} 
egyezség lehetőségét deklarálja, illetve azt határozza meg, hogy ilyen egyezség esetén a hagyatékot öröklés jogcímén az egyezségben foglaltaknak megfelelően kell átadni. ${ }^{572}$ Az osztályos egyezség fogalmát nem a Ptk., hanem a Hetv. adja meg, eszerint osztályos egyezség a hagyatéki eljárásban az örökösként érdekeltek között létrejött - a hagyatékban való részesedés mellett és kizárólag a hagyatéki vagyonra (annak egészére vagy részére) vonatkozóan kötött -, a hagyatékból való részesedést a hagyaték megnyíltára visszamenőleges hatállyal meghatározó, élök közötti jogügyletnek nem minősülő egyezség, ${ }^{573}$ amiben akár akként is megállapodhatnak az örökösök, hogy a házastárs számára haszonélvezetet alapítanak. ${ }^{574}$

„Az osztályos egyezség joghatásában abban különbözik a kötelmi jogi jellegű egyezségektől, hogy osztályos egyezség esetében a jogutódlás jogcíme öröklés. Ennek a körülménynek egyik fontos következménye az, hogy a jogutódlás a hagyaték megnyílására visszamenő hatállyal következik be."575 A másik anyagi jogi jogkövetkezmény pedig az illetékekröl szóló 1990. évi XCIII. törvény 10. § (3) bekezdése alapján történő eltérő illetékkiszabás. Eszerint ha az örökösök a megnyílt örökségre nézve maguk között osztályos egyezséget kötnek, mindegyik csak a neki jutott örökrész értéke után járó öröklési illetéket köteles megfizetni. A Ptk. megalkotásakor azzal számoltak, hogy az osztályos egyezségek száma növekedni fog, mert ebbe az irányba mutat a hagyatékok értékének növekedése és összetételük komplexebbé válása, továbbá a hagyományos özvegyi jog megszüntetése is ezt a tendenciát fogja erösíteni. ${ }^{576}$

Az esetbeli helyzetekre leképezve az osztályos egyezség keretei között több örökös megállapodhat úgy, hogy csak az egyik kapja meg a társasági vagyoni részesedést, elkerülve ezzel közös tulajdonú üzletrész, valamint az ezzel együtt esetleg felmerülő problémák létrejöttét, illetve megváltják a haszonélvezetet.

A további elemzés alapjául szolgáló döntésben ${ }^{577}$ tényállása szerint egy kft. tagjának halála után üzletrészét törvényes öröklés címén fele-fele arányban gyermekei örökölték meg a túlélő házastárs özvegyi haszonélvezeti jogával terhelten. Változásbejegyzési eljárás során kérték az elhunyt tag törlését és a két gyermek tagként történő bejegyzését. A cégjegyzékben azonban nem megfelelően vezették át: kettő

\footnotetext{
${ }^{572}$ Ptk. 7:93. §

${ }^{573}$ Hetv. 6. $\S(1)$ bek. k) pont

${ }^{574}$ Ptk. 7:58. § (3) bek.

${ }^{575}$ Vékás - Weiss 2499.

${ }^{576}$ Vö. Vékás - Weiss 2499.

577 ÍH 2009. 130.
} 
önálló üzletrészként jegyezték be a gyermekek üzletrészét, holott annak mértéke százhúszezer forint volt (amit az üzletrészek legkisebb mértékére vonatkozó rendelkezések szerint nem lehet kettéosztani). Az első fokon eljáró bíróság egy későbbi üzletrész-átruházás bejegyzése során észlelte ezt, és felhívta a társaságot a törvénysértő helyzet orvoslására, a társaság pedig ennek érdekében kijavítási kérelemmel élt. Ezt a kérelmet a bíróság elutasította, álláspontja szerint csak úgy lehetséges az anomáliát orvosolni, hogy megváltják a haszonélvezetet, és erre kötelezte is a tagokat törvényességi felügyeleti eljárás terhe (ezzel együtt, ahogy azt a másodfokon eljáró Fővárosi Ítélőtábla is kiemelte, törvényességi felügyeleti eljárás eredményeként kiszabható joghátrányok) kilátásba helyezésével. Az ítélőtábla e fellebbezett végzéssel összefüggésben azt állapította meg, hogy a cégbíróság kizárólag a cégek felett bír bárminemű (bejegyzési -, változásbejegyzési -, törvényességi felügyeleti) eljárással, a gazdasági társaság tagjai vonatkozásában nem bír ilyen jogosultsággal. Az öröklés folytán bekövetkező módosulások bejegyzésére irányuló eljárásban kellett volna észlelnie az első fokon eljáró bíróságnak, hogy a kérelem és a hozzá tartozó mellékletek tartalma ellentétes: a hagyatékátadó végzés és a tagjegyzék egyértelmüen közös tulajdonú üzletrész keletkezését támasztották alá, míg maga a kérelem önálló üzletrészek bejegyzésére irányult; ezen kívül a meghalt tag törlését nem a halál időpontjával kérték, jóllehet tagsági jogviszonya kétséget kizáróan a halál tényével szünt meg. Az elsőfokú bíróság az ellentmondásokat figyelmen kívül hagyva a kérelem szerint jegyezte be a változásokat, ami azt jelenti, hogy ezek az adatok már a bejegyzéskor törvénysértőek voltak. A régi Ptk. 615. § (1) bekezdése szerint az örökhagyó házastársa, bejegyzett élettársa örökli mindannak a vagyonnak a haszonélvezetét, amelyet egyébként nem ő örököl. Ebbe a körbe tartozik a jogeset alapjául szolgáló üzletrész is. A haszonélvezeti jog megváltásával együtt jár az, hogy az özvegy is tulajdonossá válik, akinek ilyen minősége nem biztos, hogy megfelel a társaság, illetve annak bármely tagjának az érdekeinek. Az üzletrész átszállását nem zárta ki a társasági szerződés, mint ahogy azt a Gt. alapján ki lehetett kötni, ezért az ítélőtábla meglátása szerint az örökösökről nemkívánatosságuk nem volt elmondható. Az eljáró fórum azt is kiemelte, hogy a társaság többi (túlélő) tagjának számolnia kell bármelyik másik tag halálával, azzal együtt e személy lehetséges örököseinek kilétével, azaz végső soron az üzletrész új tulajdonosainak személyeivel. A cégbíróság a törvényességi felügyeleti eljárást csak a Ctv. 72-84. §-aiban meghatározott keretek között folytathatja le, a Ctv. 81. §-ában meghatározott intézkedéseket hozhatja, éppen 
ezért nincs hatásköre arra, hogy a cégek tulajdonosainak privátautonómiájába tartozó, személyes megfontolások alapján hozandó döntéseit befolyásolja, ez szétfeszítené a törvény adta lehetőségeket.

Az örökösök nemkívánatosságát, illetve az örökösök személyének ismeretét illetően megjegyzendő, hogy a társaság tagja alapvetően a többi taggal számol, az ő társaságbeli tevékenységükre alapozza saját döntéseit is. Továbbá legfeljebb csak a lehetséges törvényes örökösöket ismerheti, amennyiben a tagok a magánéletükbe is bepillantást nyújtanak a többi tag számára, de a társaság személyegyesítő jellege a tag családjának ismeretét nem feltételezni, ahogy egyébként közkereseti és betéti társaságoknál sem. Nem említve azt a helyzetet, amikor a törvényes örökösök közül választ valakit végrendeleti örökösként, vagy egy, ezen a körön kívül eső személyt nevez örökösévé valamely végintézkedési formával, vagy a lehetséges örökös kiesik az öröklésböl. ${ }^{578}$

Röviden érdemes kitérni a haszonélvezeti jog megváltására, mert az első fokon eljáró bíróság az üzletrész megváltását követelte a tagoktól. Miért állapíthatta meg azt az ítélőtábla, hogy ez a kötelezés sérti a tagok magánautonómiáját?

A megváltás szabályai eltérőek a régi és a hatályos Ptk.-ban: a változás lényege abban áll, hogy a leszármazók már nem követelhetik a haszonélvezet megváltását, amihez érdemes hozzátenni, hogy régi Ptk. alapján az örökhagyóval közösen lakott lakásra és az ahhoz tartozó berendezési és felszerelési tárgyakra előző kódexünk hatálya alatt sem kérhették a leszármazók a megváltást, ${ }^{579}$ az üzletrészre a contrario igen. A megváltásra nincs időbeli korlátozás, de a Ptk. előírja, ${ }^{580}$ hogy a megváltási jog gyakorlásánál az állagörökös leszármazók méltányos érdekét is figyelembe kell venni. ${ }^{581}$ A szabályozásból kikövetkeztethető, hogy a megváltási jog személyhez füződő, arra akarata ellenére senki sem kényszeríthető, éppen ezért jogszabálysértő volt az első fokon eljáró bíróság azon felhívása, miszerint ha nem kerül sor az üzletrész megváltására, úgy törvényességi felügyeleti eljárást fog indítani, ilyen intézkedést nem is tehet.

\footnotetext{
${ }^{578}$ Vö. Besenyei 2009. 37.; Besenyei 2004. 504.

${ }^{579}$ Vékás 2014b. 107.

${ }^{580}$ Ptk. 7:59. § (1) bek.

${ }^{581}$ Vékás 2014b. 107-108.
} 


\subsubsection{Az Äzletrész öröklése ági öröklés útján}

Az ági öröklés ${ }^{582}$ lehetősége társasági részesedések, köztük üzletrészek esetében is felmerült a bírói gyakorlatban. A BDT 2005. 1288. számú eseti döntés tényállása alapján a túlélö házastárs felperest a keresete szerint - miután az üzletrész öröklését kizárták, a társaság pedig azt magához váltotta - az üzletrész megváltása címén, mint törvényes örököst a társaság vagyoni értékének 10\%-a illette volna meg. Az alperesek, az örökhagyó szülei a kereset elutasítását kérték arra hivatkozással, hogy az üzletrész ellenértékét ingyenesen biztosították az örökhagyónak, így ági öröklés címén az üzletrészt, illetve az annak megváltása iránti igényt megörökölték.

A másodfokon eljáró ítélőtábla elvi éllel szögezte le, miszerint a társasági jogviszonyokban az öröklésre nincsen egységes rendelkezés, a szabályok az egyes társasági formáknál jelentősen eltérnek. Miután a korlátolt felelősségü társaság átmenetet képez a személyegyesítő- és a tőketársaságok között, sok a tagok személyes kapcsolataira épülő bizalmi elem. Ennek megfelelően alakul a társaságbeli üzletrészek öröklésének szabályozása is.

Az akkor hatályos gazdasági társaságokról szóló törvény szerint (a hatályos szabályozáshoz hasonlóan) a tag halálával üzletrésze átszáll a jogutódra. Fő szabály szerint tehát érvényesült az ipso iure öröklési rend. A korlátolt felelősségű társaság tagsága azonban a jogutódok taggá válását megakadályozhatta akképp, hogy a társasági szerződés az üzletrész átszállását kizárta, ilyenkor azonban a társasági szerződésben rendelkezni kellett az üzletrésznek a tagok vagy a társaság által történő megváltásáról. Ez lényegében annyit jelentett, hogy a tag örökösét nem az üzletrész, hanem egy elszámolási (megváltási) igény illette meg.

Az elsőfokú bíróság az ági öröklés szabályait azért nem alkalmazta, mert álláspontja szerint ági öröklés alá csak a hagyatékban meglévő vagyontárgy eshet. Vagyontárgy csak valamely birtokba vehető dolog lehet, a korlátolt felelősségü társaság üzletrésze pedig nem dolog. Ezzel szemben megjegyzendő, hogy az üzletrészek is örökölhetőek.

$\mathrm{Az}$ alperesek arra tekintettel kérték az ági öröklés szabályainak alkalmazását, hogy az üzletrész ingyenes juttatásként háramlott róluk az örökhagyóra. Bár azt állították, hogy az üzletrész ellenértékét biztosították ingyenesen az örökhagyónak, a peradatok szerint a pénzt a törzsbetét befizetési kötelezettség teljesítése érdekében

${ }^{582}$ Ptk. 7:67-7:71. § 
bocsátották az örökhagyó rendelkezésére. Az örökhagyó a pénz felhasználásával a törzsbetétet szolgáltatta, a bejegyzést követően pedig a törzsbetét helyébe - eltérö tartalommal - az üzletrész lépett. A régi Ptk. ági öröklésre irányadó szabálya kizárta a redintegrációt, ami azt jelentette, hogy az ági öröklés szabályai nem terjedtek ki az ági vagyontárgy helyébe lépett vagy az ági vagyontárgy értékén vásárolt vagyontárgyra. ${ }^{583}$ Ezért állapíthatta meg azt végső soron az ítélőtábla, hogy az üzletrész öröklésénél az ági öröklés szabályai akkor sem érvényesülhetnek, ha az örökhagyó az üzletrészt ági vagyonnak minősülő pénz vagy apport szolgáltatásával teljesített törzsbetét ellenértékeként szerezte meg, mert az üzletrész az ági vagyontárgy helyébe lépett. Az örökhagyó az alperesek által juttatott pénzt a törzsbetét befizetésekor felhasználta, a készpénz a hagyatékban már nincs meg, így az ági öröklés szabályai ebben a tekintetben sem érvényesülnek. ${ }^{584} \mathrm{Az}$ új szabályozásnak megfelelően a jogeset más elbírálás alá esne, a Ptk., beépítve a korábbi törvényrontó legfelsőbb bírósági gyakorlatot, lehetővé teszi az ági öröklés szabályainak alkalmazását az ági vagyontárgy helyébe lépett vagy értékén vásárolt vagyontárgyra. ${ }^{585} \mathrm{~A}$ szabály megváltoztatása előnnyel jár, mert „piacgazdasági körülmények között nem kis gondot jelentett az is, hogy a redintegráció tilalma akadályozta a gazdasági társaságba bevitt vagyontárgy (pénz, apport) ági jellegének megtartását is." ${ }^{, 586}$

Ugyanez az eset másik problémát is megvilágított, nevezetesen az üzletrészek értékelésével kapcsolatosan: kellő szakismerettel rendelkező és megfelelő összehasonlító adatok birtokában lévő szakértő kirendelésével kell tisztázni a társaság 100\%-os üzletrészének az örökhagyó halála időpontjában fennálló forgalmi értékét, majd ennek figyelembevételével kell meghatározni az örökhagyó üzletrésze által képviselt forgalmi értéket. A korábbi jogi helyzetnek megfelelően tekintettel kellett lenni arra, hogy a társasági szerződés azért zárta ki az üzletrész öröklését, hogy kívülálló harmadik személyeknek a társaságba történő automatikus belépését megakadályozza. A konkrét esetbeli üzletrész forgalmi értékének megállapításánál ezért döntően azt kellett figyelembe venni, hogy a társaság üzletrészeinek 90\%-val rendelkező tag szerezte meg az örökhagyó üzletrészét, és ez által a társaság egyedüli tagjává vált, a másik tag életében lényegében nem tudta véleményét érvényesíteni, a társaság osztalékot nem fizetett, az üzletrész tulajdonképpen eladhatatlan, így az

\footnotetext{
${ }^{583}$ régi Ptk. 613. $\S(1)$ bek.

${ }^{584}$ Vö. Vékás 2013. 1016.

${ }_{585}$ Ptk. 7:70. § (2) bek., Vékás - Weiss 2464.

${ }^{586}$ Vékás - Weiss 2465.
} 
igazságügyi könyvszakértő által feltárt értékcsökkentő tényezők nem érvényesültek. Azaz a szabad piaci értékmegítélés nem lehet kizárólagos szempont, az üzletrész értéke legfeljebb a névértékével egyezett meg.

A FIT-H-PJ-2014-284. ügyben első fokon eljáró bíróság szerint nem volt bizonyított az üzletrészen fennálló ági jelleg: az örökhagyó három kft.-ben üzletrészei alapján dolgozott és abból jövedelemhez jutott, az üzletrészek megszerzése óta eltelt huzamosabb idő $(8,10$, illetve 12 év) arra utalt, hogy azok az örökhagyó munkájával teremtett értéket képeznek. Ezért a felpereseknek kellett volna bizonyítani - bár ezt nem tették -, hogy az üzletrész értékét az örökhagyó annak megszerzésekor nem fizette ki részükre a cégekben végzett munka révén, ennek ellenkezője esetén az örökhagyó az üzletrészen, saját jogán, tulajdonjogot szerzett. A felperesek fellebbezésükben arra hivatkoztak: a tagok személye alapján eldönthető, hogy családi vállalkozásokról van szó; kettő társaság azonban ténylegesen nem müködött, éppen ezért csak az egyikben lehetett az örökhagyó munkavállaló. A másodfokú bíróság szerint az első fokú fórum ítéletének saját jogú tulajdonszerzésre vonatkozó része felesleges, mivel az örökhagyó az üzletrészek tulajdonjogát a cégek alapításával megszerezte, jogszerzése független attól, hogy a törzstőke befizetése milyen forrásból származott. A felperesek csak állították, hogy az üzletrészeket, illetve a befizetett összegeket ajándékozták, de azt nem bizonyították az ági öröklés megállapíthatóságához. Önmagában az a tény, hogy családi vállalkozásokról van szó, nem elegendő az ági jelleg megállapításához.

\subsubsection{Részvénytársaságok}

A részvénytársaság esetében a kibocsátó társaságban gyakorolható tagsági jogokat megtestesítő, névre szóló, névértékkel rendelkező forgalomképes értékpapír, a részvény $^{587}$ a Ptk. 5:14. § (2) bekezdése alapján tulajdonjog tárgyaként viselkedhet, éppen ezért örökölhető. ${ }^{588}$ Értékpapír jellegüknél fogva a Hatodik Könyv vonatkozó rendelkezései is irányadóak rájuk ${ }^{589}$ megtestesíti a részvényesi minőségből folyó jogokat, ${ }^{590}$ a tagsági jogokról pedig csak részvénytársaság állíthat ki értékpapírt. ${ }^{591} \mathrm{~A}$ részvényes személyében bekövetkező változás tipikusan szerződésen alapul, de más

\footnotetext{
${ }^{587}$ Ptk. 3:213. § (1) bek., Harsányi 2010. 43-45.

${ }^{588}$ Kisfaludi 1991. 150.

${ }^{589}$ Ptk. 6:565-6:571. §, lásd még Harsányi 2015. 47-51.

${ }^{590}$ Harsányi 2016. 202.

${ }^{591}$ Ptk. 3:11. §
} 
jogi tények, így pl. öröklés vagy jogutódlás is eredményezhetik, ${ }^{592}$ figyelemmel az Ötödik Könyv rendelkezéseire is. Nyomdai úton elöállított részvény tulajdonjogának nem átruházás - így öröklés - jogcímén történő átszállása esetén az új részvényes kérésére az igazgatóság a tulajdonosváltozást a tulajdonszerzést igazoló okiratok alapján, a részvény hátoldalán vagy toldatán - a tulajdonosváltozást igazoló okirat megjelölése mellett - átvezeti. A tulajdonosváltozást igazoló okirat öröklési jogi szempontból lehet hagyatékátadó végzés, de akár öröklési perben hozott jogerős bírói ítélet is, vagy öröklési bizonyítvány. A változás igazgatóság általi átvezetése a forgatmányi láncolat részét képezi; de nem az igazgatóság forgatmányoz, hanem a forgatmányt a törvényben meghatározott feltételek fennállása esetén pótolja. ${ }^{593}$

Dematerializált részvény megszerzése esetén a korábbi részvényes értékpapírszámlájának megterhelését és a megszerzendő részvényeknek az új részvényes értékpapírszámláján való jóváírását az értékpapír-számlavezető az új részvényes kérelmére, a tulajdonszerzést igazoló okirat alapján hajtja végre. ${ }^{594}$

A részvény által megtestesített tagsági jogokhoz mind vagyoni, mind szervezeti jellegü jogosultságok is tartoznak, amelyek egységéhez a részvényeseknek, így a részvényt öröklés útján megszerző örökösöknek joguk van. Ezért a társaság müködőképessége szempontjából méltányolható érdekük füződik ahhoz, hogy azok ne különüljenek el, ezért helye lehet az özvegyet a régi Ptk. alapján megillető törvény szerinti özvegyi haszonélvezeti jog korlátozásának a részvények vonatkozásában, föleg akkor, ha a többi vagyontárgy feletti özvegyi joga biztosítja szükségleteinek kielégítését. $^{595}$

A részvényesek egyik nevesített joga a részvénykönyvbe történő bejegyeztetés joga, ami azért jelentős, mert a részvényes a részvénytársasággal szemben ebbéli jogi helyzete alapján őt megillető jogokat a bejegyzés után gyakorolhatja. Ahogy azt a Ptk. is kijelenti, a bejegyzés elmaradása a részvényes részvény feletti tulajdonjogát nem érinti, ${ }^{596}$ azaz a részvényes halálával örökösei annak forgalomképessége miatt automatikusan megszerzik, nem szükséges a bejegyzés.

\footnotetext{
${ }^{592}$ Vezekényi 732.

${ }^{593}$ Uo.

${ }^{594}$ Ptk. 3:221. §, Fabó 2014c. 412-413.

595 ÍH 2015. 145.

${ }^{596}$ Ptk. 3:246. § (1) bek.
} 
A részvények forgalomképességének törvénybeli korlátozásának ${ }^{597}$ megjelenése a dolgozói részvény. A dolgozói részvény olyan részvényfajta, ${ }^{598}$ amely a részvénytársaságnál teljes vagy részmunkaidőben foglalkoztatott munkavállalók számára részvényesi jogokat biztosít. ${ }^{599}$ A kibocsátás elsődleges célja az, hogy a munkavállaló számára részvényesi jogokat biztosítson, illetőleg ösztönözze a munka eredményesebb elvégzésére. ${ }^{600} \mathrm{~A}$ dolgozói részvény a hagyaték része lesz, és mint ilyenről, végrendelkezni is lehet.

Az élők közötti forgalomképesség korlátozását a Ptk. 3:237. § (1) bekezdésében foglalt rendelkezés jelenti, ami szerint az ilyen részvény csak a rt. munkavállalóira és azokra ruházható át, akik számára a társaság alapszabálya korábbi munkaviszonyukra figyelemmel biztosítja. A korlátozás öröklés esetén az alábbiak szerint jelenik meg: ha az örökhagyó hagyatékában ilyen értékpapír található, azt az örökös megszerzi, de ha ő nem ugyanannál a részvénytársaságnál dolgozik, mint amelyik a részvényt kibocsátotta, vagy nem minősül más olyan személynek, akire nézve az alapszabály ezt a lehetőséget megadja, kötelezettsége, hogy átruházza a részvényt,

- ha hagyatéki eljárásra nem került sor, az örökhagyó halálától;

- hagyatéki eljárás esetén a hagyaték teljes hatályú átadásáról rendelkező hagyatékátadó végzés jogerőre emelkedése napjától;

- öröklési per esetén a bírósági ítélet jogeröre emelkedése napjától számított hat hónap elteltét követő első közgyülésig. ${ }^{601}$ A kezdőnap a bizonytalanságok elkerülése (pl. álörökös) érdekében olyan időpontra esik, amikor már pontosan megállapítható az örökös személye. Ha eddig az időpontig nem kerül sor az átruházásra, vagy bevonják a részvényt, vagy más részvényfajtává átalakítva a társaság értékesíti, egyúttal a törvény kimondja, hogy akkor a részvény névértéke megilleti az örököst. ${ }^{602}$ Természetesen az átalakított részvényt - amennyiben olyan típusú értékpapírként hozzák forgalomba - az örökös megszerezheti. Amennyiben az örökösnek módjában áll, javasolt, hogy a dolgozói részvényt ellenérték fejében ruházza át, mivel ekkor akár a névértéken felüli összeghez juthat.

Az örökös helyzete speciális e részvényfajtánál: a részvénynek tulajdonosa, de az ahhoz kapcsolódó jogokat nem gyakorolhatja, a részvénykönyvbe nem jegyeztetheti

\footnotetext{
${ }^{597}$ Orosz K. 11.

${ }^{598}$ Ptk. 3:228. § (1) bek. c) pont

${ }^{599}$ Papp 2011b. 459.

${ }^{600}$ Papp 2011b. 459.; Gadó 3.

${ }^{601}$ Ptk. 3:237. § (3) bek.

${ }^{602}$ Ptk. 3:238. $\S$ (4) bek.
} 
be magát, mert a dolgozói részvény az örökhagyó személyéhez kötött. ${ }^{603}$ Mindezek a szabályok nem jutnak érvényre akkor, ha az örökös, vagy több örökös közül valamelyik, vagy mindegyik a kibocsátó részvénytársaság dolgozója vagy dolgozói részvény megszerzésére más okból jogosult: velük szemben ezek a korlátozások nem érvényesülnek, nem kell elidegeníteniük az örökölt dolgozói részvényeket. ${ }^{604}$

$\mathrm{Az}$ osztrák részvénytársaságokra vonatkozóan ugyanolyan öröklési jogi szabályok irányadóak, mint a kft.-re, azaz az elhunyt részvényei alapvetően a hagyatékba tartoznak. Ezeknél a társaságoknál az alapszabályba nem vehetők fel a tagok magukhoz váltására vonatkozó igényre irányuló rendelkezések, hasonló kitételre szindikátusi szerződésben kerülhet sor. ${ }^{605}$

\footnotetext{
${ }^{603}$ Papp 2011b. 461.

${ }^{604}$ Lásd még Orosz K. 11., Sándor T. 2014b. 291.

${ }^{605}$ Kalss - Probst 671., Kalss 2015b. 112-119.
} 


\section{Származtatott alapítás}

\subsection{Bevezetés}

A gazdasági társaságok átalakulása, egyesülése, illetve szétválása származtatott alapításnak minősül, a jogutód új társaság bejegyzése alkalmával nem ex nihilo, hanem jogelőddel létesül, egyúttal a jogalkalmazás során a kiválasztott eljárásnak megfelelő szabályok figyelembe kell venni a gazdasági társaságok alapítására irányadóakat is. A jogelőd szemszögéből nézve pedig a jogelőd gazdasági társaság jogutóddal szünik meg. Ezért mondható el az, hogy az átalakulás szabályrendszere az alapítás és a megszünés jellemzőit is tükrözi, azokat egyesíti. ${ }^{606}$ „Az átalakulás, egyesülés, szétválás a jogi személyek státuszváltozása, a jogi személyek közötti alanyváltozás, a jogi személy(ek) jogutóddal való megszünése, valamint jogelőddel történő keletkezése (származtatott alapítás)." ${ }^{\text {"67 }}$ A származtatott alapítás indokául a korábbihoz képest kisebb vagy éppen nagyobb szervezet kialakítása, cégek fuzionálása vagy éppen kisebb gazdasági egységekre való szétbontása szolgálhat. ${ }^{608}$

A korábbi szabályozástól eltérően a 2014. március 15-én hatályba lépett Ptk. és a kapcsolódó jogszabályok alapján az átalakulás alatt már csak a társasági forma megváltoztatását kell érteni, ${ }^{609}$ a gyüjtőfogalom jelleg megszünt, nem tartalmazza magában az egyesülést és a szétválást, a dolgozat további részében ezért kerül megkülönböztetésre a három eljárás.

A Ptk.-n túlmenően releváns szabályokat az Átv. tartalmazza. A törvény 1. alapján rendelkezéseit a Polgári Törvénykönyvvel együtt kell alkalmazni a gazdasági társaság, a szövetkezet, valamint az egyesülés átalakulása, egyesülése, szétválása során, illetve rendelkezéseit megfelelően alkalmazni kell abban az esetben, ha más jogszabály a Ptk.-nak a jogi személy átalakulására, egyesülésére, szétválására vonatkozó szabályainak alkalmazását írja elő.

Az egyes eljárások bármely szakasza alatt elhalálozhat valamely érintett társaság tagja. A halál folytán társasági típusonként eltérő jellegü jogutódlás következik be, amit meghatározott körülmények között szintén figyelembe kell venni az eljárások során.

\footnotetext{
${ }^{606}$ Papp 2011b. 107.

${ }^{607}$ Papp 2014a. 438.

${ }^{608}$ Gál - Adorján 17.

${ }^{609}$ Papp 2014a. 438.; Török G. 2014. 76.; BDT 2015. 3400., Kisfaludi 2014a. 256., Török G. 2011. 8.; Gál 2014. 3.
} 
A szabályozási struktúra bemutatása után az átalakulás, majd az egyesülés és a szétválás szabályait ismertetem, ehhez illesztve az átalakulás során valamely tag halálával felvetett kérdéseket.

\subsection{A szabályozástól való eltérés lehetősége}

A korábbi szabályozáshoz képest újdonságként (de nem teljesen példa nélkül, lásd 1988. évi VI. törvény a gazdasági társaságokról) jelentkezik az is, hogy a társasági szerződésben a Ptk. 3:4. § alapján bizonyos tárgykörökben (a jogi személy tagjai, illetve alapítói egymás közötti és a jogi személyhez füződő viszonya, valamint a jogi személy szervezete és müködése) további meghatározott kivételek figyelembe vételével eltérhetnek a Ptk.-ban foglaltaktól. A jogirodalom felvetette, hogy a szervezet-átalakító szabályok - különösen pedig az említett külön törvényben meghatározott szabályok kötelezőek-e. Osztom azt az álláspontot, miszerint tekintettel arra, hogy a 2013. évi CLXXVI. törvény nem rendelkezik az eltérés lehetőségéről, ahogy azt a Ptk. teszi, ezért e szervezeti szabályoktól nem lehet a társasági szerződésben eltérni. ${ }^{610}$ Nincs arra lehetőség, hogy jogszabályi felhatalmazás nélkül a Ptk. hatókörén kívül található jogszabályoktól - így az átalakulási törvénytöl is - eltérjenek a felek, ${ }^{611}$ amely állásponttal teljes mértékben egyetértek. Ehhez hozzá lehet tenni azt, ha a tagok e szabályoktól eltérhetnének a társasági szerződésben, és adott esetben társaságok egyesüléséről van szó, a szerződések pedig egymástól eltérő rendelkezéseket tartalmaznak, elöbb módosítani kellene ezeket az összhang érdekében, és csak ezután valósulhat meg a társaságok egyesülése, ami jelentős időbeli késedelmet okoz az eljárás lebonyolításánál. Átalakulás esetén csak egy társaság érintett az eljárásban, ennél az eltérés lehetősége nem okozna problémát, míg szétválásnál a beolvadásos kiválás vagy a beolvadásos különválás vonatkozásában az egyesüléshez hasonló tényállás esetén a kifejtett lehetőségek következhetnének be. Kérdéses lehet, mennyire élnének egy ilyen hipotetikus esetben a felek a lehetőséggel, ahogy természetesen az sem elhanyagolandó, milyen keretek között tehetnék meg.

\footnotetext{
${ }^{610}$ Sárközy 2014. 45.

${ }^{611}$ Dzsula-kommentár, lásd még Metzinger 48-49.
} 


\subsection{A származtatott alapítás hatályos szabályozási struktúrája}

A Ptk.-ba illesztett társasági jogi szabályozással egy sokrétegü jogi struktúrát kell alapul venni a jogalkalmazás során. A jogi személyek átalakulása esetén alkalmazni kell

- egyrészt a jogi személyek közös szabályait,

- másrészt a gazdasági társaságok közös szabályainál található átalakulási szabályokat,

- harmadrészt részvénytársaságok esetében az e társasági formánál megtalálható ezekre vonatkozó speciális szabályokat;

- negyedrészt figyelembe kell venni az Átv.-ben fellelhető jogi személyek átalakulásának,

- ötödrészt ezek egyesülésének,

- illetve szétválásának szabályait,

- hetedrészt ebben a törvényben található gazdasági társaságok átalakulására, egyesülésére, szétválására irányadó közös szabályokat,

- nyolcadrészt a közkereseti és betéti társaság egymás közötti átalakulására irányadó szabályokat,

- kilencedrészt a zártkörüen működő részvénytársaságok esetén ezek szétválására vonatkozó speciális rendelkezéseket,

- mindezeken túlmenően alkalmazni kell a Ctv. és a számvitelről szóló 2000. évi C. törvény idevágó rendelkezéseit is,

- végül figyelembe kell venni a tag halála folytán bekövetkező társasági jogi jogutódlás társasági formánként eltérő megoldásait is.

\subsection{A származtatott alapítás szabályai}

Az egyesülés és a szétválás szabályainak megállapítása során a jogalkotó az átalakulás, azaz a társasági forma megváltoztatásának eljárását vette alapul, ${ }^{612}$ ezért tekintjük át először ennek az eljárásnak az előírásait.

612 3:47. § [Az átalakulás szabályainak alkalmazása]

A jogi személy egyesülésére és szétválására az átalakulásra vonatkozó szabályokat megfelelően alkalmazni kell.

Átv. 12. § A jogi személyek egyesülésére a jogi személyek átalakulásának közös szabályai - ezen alcímben foglalt eltérésekkel - megfelelően irányadóak.

Átv. 22. § (1) A gazdasági társaságok átalakulására, egyesülésére, szétválására az ezen alcímben foglalt eltérésekkel a jogi személyek átalakulásának, egyesülésének és szétválásának közös szabályait kell alkalmazni. 


\subsubsection{A gazdasági társaságok átalakulása}

A gazdasági társaságok átalakulása, egyesülése, szétválása költségigényes eljárás (adó- és illetékfizetési kötelezettség, ügyvédi, illetve könyvvizsgálói díjak), ezért csak akkor érdemes a folyamatot elindítani, ha az átalakulással elérni kívánt gazdasági cél képes ellensúlyozni ezeket. ${ }^{613}$

Alapvető szabályként rögzíti azt a Ptk., hogy a jogi személy (így a gazdasági társaság) más típusú jogi személlyé történő átalakulása esetén az átalakuló jogi személy megszünik, jogai és kötelezettségei az átalakulással keletkező jogi személyre, mint általános jogutódra szállnak át. Tekintettel arra, hogy átalakulás esetén egy új társaság jön létre, a létesítésre vonatkozó szabályokat megfelelően alkalmazni kell. ${ }^{614} \mathrm{Az}$ átalakulás befejezésével, azaz a cégjegyzékbe való bejegyzéssel „az átalakuló jogi személy megszünik, és általános jogutódjaként létrejön egy új típusú jogi személy. A legegyszerübb esetben a jogutód jogi személynek ugyanazok a tagjai lesznek, mint a jogelődnek, és a vagyona is megegyezik a jogelődével, ez azonban nem szükségszerü, mert az átalakulás során mind a tagság, mind a vagyon változhat, akár negatív, akár pozitív irányban." 615

Az átalakulás szabályainak a megfelelő alkalmazása vonatkozásában társaságok egyesülése esetére mondta ki a Fővárosi Ítélőtábla, ${ }^{616}$ hogy ez az alkalmazás az utaló szabállyal hivatkozott normának nem szó szerinti érvényesülését jelenti, hanem olyan alkalmazását, amely összhangban áll az e jogalkalmazással érintett jogintézmény eltérő sajátosságaival. A vonatkozó jogszabály szerint ${ }^{617}$ a döntéshozó szerv meghatározhatja azt a napot, amelyen az átalakulás joghatásai beállnak, ez a nap azonban nem lehet korábbi, mint a jogutód nyilvántartásba vételének napja. A jogeset tényállása szerint a beolvadásban résztvevő cég ennél korábbi időpontot határozott meg, a cégbíróság pedig a jogszabálynak megfelelően eljárva nem ezt a napot tekintette irányadónak. A cég a végzés kijavítása iránti kérelmet terjesztett elő, mivel szerinte ez a rendelkezés csak a formaváltásra irányadó, az egyesülés és a szétválás vonatkozásában nem. Az ítélőtábla azonban elutasította a kérelmet, az első fokon eljáró cégbíróság végzését helybenhagyta.

\footnotetext{
${ }^{613}$ Gál - Adorján 62.

${ }^{614}$ Ptk. 3:39. §

${ }^{615}$ Kisfaludi 2014a. 256.

${ }^{616}$ BDT 2015. 3400.

${ }^{617}$ Átv. 6. § (6) bek.
} 
Megállapítása szerint az egyesülési és a szétválási eljárásokra megfelelően, értelemszerüen alkalmazva figyelembe veendők a formaváltás eljárási rendjére, az eljárást gátló tilalmakra, a tagok speciális jogaira, illetve kötelezettségeire, stb. irányadó szabályok, ezek közé tartozik az átalakulás joghatályának megállapítása is, csak itt nem a jogutód nyilvántartásba vételének napját nem előzheti meg, hanem a jogutód változásainak nyilvántartásba vételének napjánál nem lehet korábbi a megjelölt időpont. ${ }^{618}$

Az átalakulással létrejövő jogi személy nyilvántartásba vételével egyidejüleg az átalakulással megszünő jogi személyt törölni kell a nyilvántartásból (konstitutív és ex nunc hatály, azonos időbeli keletkezés és megszűnés). ${ }^{619}$ A létrejövő jogi személy nyilvántartásba vételéig az átalakuló jogi személy a bejegyzett jogi személy típusban folytatja tevékenységét. „Amennyiben a nyilvántartó bíróság az átalakulás bejegyzését elutasítja, a jogi személy korábbi (eredeti, bejegyzett) formájában müködik tovább. A jogalkotó fenntartja az átalakulás egységes elbírálásának elvét: a bíróság vagy helyt ad az átalakulás bejegyzésére irányuló kérelemnek és a jogelődöt a jogutódra történő utalással törli a nyilvántartásból, egyúttal pedig a jogutódot bejegyzi a nyilvántartásba, vagy minden kérdésben elutasító döntést hoz." ${ }^{620}$

A kötelező átalakulás esetétől ${ }^{621}$ eltekintve a gazdasági társaság tagjai szabadon döntenek az átalakulás kezdeményezéséről az átalakulás módjának és a jogutód jogi személynek a meghatározásával. ${ }^{622}$ „Az átalakulás a jogi személy státuszát érintő, alapvető kérdés, ezért ez a döntés nem tartozhat az ügyvezetési döntések körébe, a döntést a tagok vagy alapítók hozhatják meg az átalakuló jogi személyre vonatkozó szabályok szerint." ${ }^{623}$ A döntés során ugyanakkor figyelemmel kell lenni arra, hogy az átalakulás során olyan gazdasági társasági formát kell választani, amely esetében legalább a törvény által az adott formára elöírt legkisebb mértékü, vagy - ilyen törvényi elöírás hiányában - a jogi személy által meghatározott jegyzett tőke követelménynek a

\footnotetext{
${ }^{618}$ Vö. Ctv. 57. § (2) bek.

${ }^{619}$ Papp 2014a. 441.

${ }^{620}$ BH 2004.373., LB Cgf. II. 30.159/2000., FÍT 13. Gf. 43.019/2010/2. Papp 2011b. 127.; Papp 2014a. 441.

${ }^{621}$ Ptk. 3:133. § (2) bek.: Ha egymást követő két üzleti évben a társaság saját tőkéje nem éri el az adott társasági formára kötelezően előírt jegyzett tőkét, és a tagok a második év beszámolójának elfogadásától számított három hónapon belül a szükséges saját tőke biztosításáról nem gondoskodnak, e határidő lejártát követő hatvan napon belül a gazdasági társaság köteles elhatározni átalakulását. Átalakulás helyett a gazdasági társaság a jogutód nélküli megszünést vagy az egyesülést is választhatja.; ÍH 2010. 39.

${ }_{622}$ Ptk. 3:41. § (1) bek.

${ }^{623}$ Kisfaludi 2014a. 257.
} 
jogi személy az átalakulással eleget tud tenni, ${ }^{624}$ ennek hiányában azt meghiúsultnak kell tekinteni.

Nemcsak a társasági forma megváltoztatása tartozik a tagok magánautonómiájába, hanem az is, részt kívánnak-e venni a jogutód társaságban. Az átalakulási terv közlésétől számított harminc napon belül nyilatkozhatnak, az átalakulással létrejövő jogi személy tagjaivá kívánnak-e válni. Az ilyen jognyilatkozatot tett tagok tagsági jogviszonya az átalakulás időpontjában, annak bejegyzésekor megszünik, és az átalakuló jogi személy vagyonából olyan hányadra jogosultak, amelyet a jogi személy jogutód nélküli megszűnése esetén igényelhetnének. ${ }^{625}$ „Értelemszerűen az átalakulási tervet az átalakulásban részt venni nem kívánó tagok nyilatkozata alapján módosítani kell."

A társaságtól megváló tagot megillető vagyonhányad kiadásának határidejére a Ptk. 3:134. § (2) bekezdése, valamint az Átv. 6. § (5) bekezdése a jogutód nyilvántartásba vételétől számított hatvan napot határoz meg, amelytől az érintett felek megállapodása eltérhet. Ez az idő hatvan napnál több, illetve kevesebb is lehet, miután se a Ptk., se az átalakulási törvény nem határozza meg azt, hogy valamely irányba történő eltérés semmis lenne. Az elszámolás alapja a független könyvvizsgáló által auditált és a legfőbb szerv által elfogadott jogelődi vagyonmérleg-tervezet. Ennek alapján állapítható meg a tag járandósága, és ez teherként szerepel a jogutód társaság vagyonmérleg-tervezetének „Különbözetek” oszlopában. Vagyonkiadásról ekkor még nem lehet szó, miután az átalakulás folytán távozni kívánó tag tagsági viszonya még nem szünt meg. ${ }^{627}$

Az átalakulásról a tagok az átalakulási terv elfogadásával határoznak, amit legalább háromnegyedes szótöbbséggel hoznak meg, ami garancia arra, hogy megfelelő konszenzus alakuljon ki az átalakulás szükségességében, ${ }^{628}$ és annak megvalósításában.

Ha például halál miatt a kkt. vagy bt. tagjainak száma egyre csökkent, illetve nincs két eltérő pozíciójú tag betéti társaságnál, úgy igaz lehet az, hogy a megmaradt tag dönthet akképp, hogy egyszemélyes korlátolt felelösségü társasággá (de akár részvénytársasággá) alakítja át a céget. Ebben az esetben legkésőbb az átalakulás bejegyzése iránti kérelem előterjesztésekor a meghalt tag cégjegyzékből történő törlése

\footnotetext{
${ }^{624}$ Átv. 22. § (3) bek.

${ }^{625}$ Ptk. 3:42. §, Átv. 6. § (3) bek.; Gál 2014. 3.

${ }^{626}$ Papp 2014a. 440.

${ }^{627}$ Gál - Adorján 92-93.

${ }^{628}$ Ptk. 3:43. § (1) bek., Török G. 2014.79.
} 
iránti kérelmet is elö kell terjeszteni azért, mert a tag tagsági jogviszonya halálának napjával megszünt. A kérelmek összevetéséből egyértelmủen tisztázható, miképp kívánja elkerülni az életben maradt tag a társaság megszünését.

A Ptk. 3:40. § c) pontjában megfogalmazott korlátozás alapján, ami a szakasz címével ellentétben nem korlátozás, hanem tilalom, nem alakulhat át a jogi személy, ha a tagok vagy alapítók a társasági szerződés szerinti vagyoni hozzájárulásukat nem teljesítették. Ez a tartozás a Ptk. 7:94. § c) pontba illeszkedő örökhagyói tartozás, aminek a kielégítéséért az örökösök a hagyatéki tartozásokért való felelösség szabályai szerint helytállással tartoznak. ${ }^{629} \mathrm{Ha}$ az örökösök így teljesítették jogelődjük vagyoni hozzájárulását, úgy a társasági formának megfelelő jogutódlásra is sor kerülhet, és attól függően, hogy az örökösök taggá váltak-e vagy sem, az előbbi esetben részt vehetnek az átalakulásban.

A kkt. és bt. egymás közötti - technikai - átalakulását ${ }^{630}$ a cégbírói kar egy része (köztük Gál Judit is) éppen úgy átalakulásnak minősíti, mint annak bármely esetét, tekintve, hogy társasági formaváltás megy végbe. A jogelődöt a jogutódra való hivatkozással törlik a cégjegyzékből, a jogutód céget a jogelődre való hivatkozással jegyzik be, azzal a különbséggel, hogy a Ptk. mentesíti az átalakulás költséges és bonyolult procedúrája alól. ${ }^{631}$

$\mathrm{Az}$ átalakulás vonatkozásában három felelősségi szabályrezsim létezik: az átalakulás során a társaságtól megváló tag felelőssége aszerint alakul, hogy a társaság müködése során fennállt-e közvetett másodlagos felelőssége a társaság tartozásaiért, azaz a korlátlanul felelős tag volt-e, avagy a társaság működése során egyáltalán nem áll fenn felelőssége a társaság tartozásaiért. Ebből fakadóan két felelősségi szabályt kell megvizsgálnunk a társaságtól megváló tag felelőssége vonatkozásában. A harmadik felelősségi szabály arra az esetre vonatkozik, amikor a korlátlanul felelős tag korlátozottan felelős taggá válik az átalakulás során. ${ }^{632}$ Ugyanezeket kell alapul venni öröklés esetén is a hagyatéki tartozásokért való felelősség figyelembevételével.

\footnotetext{
${ }^{629}$ Vö. Kisfaludi 1991. 153.

${ }^{630}$ Ptk. 3:153. §

${ }^{631}$ Gál - Adorján 171.

${ }^{632}$ Török T. 2015. 236.
} 


\subsubsection{Kétüléses eljárás}

A jogi személy döntéshozó szerve az átalakulásról két alkalommal határoz. Első alkalommal az ügyvezetés előterjesztése alapján a tagok arról döntenek, egyetértenek-e az átalakulás szándékával, milyen gazdasági társasági formát válasszanak, továbbá előzetesen felmérik, ki és mekkora vagyoni hozzájárulással kíván a jogutód jogi személy tagjává válni. ${ }^{633}$ Ekkor terjesztik elő az átalakulási tervet is, amely többek között magában foglalja a jogutód jogi személyben tagként részt nem venni kívánó személyekkel való elszámolás módjáról szóló tervezetet. ${ }^{634} \mathrm{Az}$ átalakulási terv írásbeli közlésétől számított harminc napon belül írásban nyilatkozhatnak a tagok arról, ha nem kívánnak a jogutód gazdasági társaság tagjává válni. A törvény vélelmet állít fel arra az esetre, ha nem nyilatkoztak: ilyennemü jognyilatkozat hiányában úgy kell tekinteni, hogy a tag a jogutód jogi személy tagjává kíván válni. A jogutódban való részvétel elfogadása, annak elutasítása, vagy éppen a nyilatkozat hiánya nem végleges, azt az átalakulásról véglegesen döntő második legfőbb szervi ülésen megvalósuló szavazás megkezdéséig megváltoztathatja a tag. ${ }^{635}$

Sem a Ptk., sem az Átv. nem határozza meg azt a határidőt, amely alatt a tagokkal írásban közölni kell az átalakulási tervet. Dzsula Marianna szerint ${ }^{636}$ az ügyvezetésnek ezt a kötelezettségét célszerü minél korábban teljesíteni, figyelemmel az átalakulás folyamatára előírt határidőkre is. Megjegyzendő, nemcsak a határidők miatt, hanem a Ptk. 3:91. § (3) bekezdésére figyelemmel is miszerint, ha a gazdasági társasággal kapcsolatos jognyilatkozat megtétele vagy cselekmény elvégzése kötelező, e kötelezettséget késedelem nélkül kell teljesíteni.

Abban a hipotetikus esetben, ha a tag részt kíván venni az átalakulásban, az átalakulás bejegyzése iránti kérelmet már benyújtották, de ez a személy a cégbírósági eljárás alatt elhalálozik, és a kérelmet végül elutasítják, akkor az Átv. 11. § (3) bekezdése alapján az átalakulni kívánó gazdasági társaság a korábbi társasági formában müködik tovább. Az elhunyt tagot pedig halálának napjával törlik a cégjegyzékből. Megvalósulhat az az eset is, miszerint az első, az átalakulás mellett döntő ülés után hal meg valamelyik tag. Szintén az eredeti társasági forma alapján válaszolható meg a kérdés, miképp válhatnak az örökösei taggá, de a törvény által elöírt létszám hiánya

\footnotetext{
${ }^{633}$ Átv. 2. § (1)-(2) bek.

${ }^{634}$ Átv. 3. § (1) bek.

${ }^{635}$ Átv. 5. § (1)-(2) bek.

${ }^{636}$ Dzsula-kommentár
} 
esetén kkt és bt vonatkozásában a jogvesztő hathónapos határidő miatt szükségessé válhat bizonyos intézkedések megtétele, a már elkészített dokumentumokat, amiket érinthet a tagváltozás, módosítani kell, és a hirdetményeket újra közzé kell tenni. ${ }^{637} \mathrm{Ez}$ azt jelenti, hogy a korábbi társasági formának megfelelő jogutódlás következik be öröklés esetén: a közkereseti, betéti társaságokba való belépéshez az örökösök és a társaságban bennmaradt tagok megállapodása szükséges, míg a korlátolt felelősségü társaságban és részvénytársaságban az öröklés ipso iure jellegéhez igazodó szabályok jelennek meg a körülírtaknak megfelelően, a kivételes eseteket nem számítva. Amennyiben a kérelem elutasítása ellenére annak elutasítását követően a korábbiaknak megfelelően újra át szeretnének alakulni, már a társaságba belépett örökösökkel kell kialakítani a szükséges konszenzust az egyes kérdésekben. Átalakulásban való részvételnek minősül az is, ha a tag nem nyilatkozik az adott eljárási szakaszig, ezért az ilyen helyzeteket (benyújtották a kérelmet, de azt a cégbíróság végül elutasítja) is ekképp kell kezelni valamely tag halála esetére.

Véleményem szerint, ha még az átalakulás cégbíróság előtt folyó eljárása alatt meghal a tag, de még ebben a periódusban lefolytatják a megfelelő eljárást az örökös beléptetéséhez, azaz bekövetkezik az alanyváltozás, visszavonhatják az átalakulás iránti kérelmet, ha az örökösök azzal nem értenek egyet, hiszen az átalakulási (valamint az egyesülési és a szétválási) eljárás kérelemre indul, amit vissza is lehet vonni. ${ }^{638}$ Éppen ezért ha megfelelő többséggel rendelkeznek az örökösök, az eljárást megakaszthatják, illetve adott társaság vonatkozásában eltérően döntenek az átalakulásról. A származtatott alapítás vonatkozásában így például társaságok egyesülésekor kettőnél több résztvevő társaság esetén adott társaság nem fog összeolvadni/beolvadni a másikkal/másikba, ha van több társaság rajta kívül, a többi ezt ugyanakkor minden további aggály nélkül megteheti, szétválás esetén, mivel csakis a szétváló társaság vesz részt csak az eljárásban annak kezdetekor, nem fog bekövetkezni a szétválás. Mindehhez képest arra, hogy még az első szakasz alatt beléphetne a társaságba az örökös, igen kicsi a valószínüség, mert a két ülés közötti időszak alatt a hagyatéki eljárás lefolytatására nem kerül sor.

Amennyiben a belépő örökösök nem képesek olyan többséget felmutatni, ami elegendő ahhoz, hogy a társasági forma megváltoztatására (más társaságokkal való egyesülésre, illetve más társaságokra történő szétválásra) irányuló eljárás iránt

\footnotetext{
${ }^{637}$ Dzsula-kommentár

${ }^{638}$ Ctv. 33. § (1) bek., Ctv. 33. § (3) bek.
} 
benyújtott kérelmet legfőbb szervi határozattal visszavonják, akkor az eljárás eredményeképpen a kérelemnek megfelelően fog eljárni az illetékes cégbíróság. Ha ez a jogi helyzet valamely örökös érdekével ellentétes lenne, az új társasági formának megfelelően megszüntetheti a tagsági jogviszonyát, így korlátolt felelősségü társaságban az üzletrészét, részvénytársaságban a részvényét átruházhatja. Ha az új társaság közkereseti vagy betéti társaság, miután ezeknél a társaságoknál egyhangúság kell az ilyen szervezeti döntéshez, ${ }^{639}$ bármely tag vétója az egész átalakulási eljárást megakaszthatja. A többi társaságnál a Ptk. szerint legalább háromnegyedes többség szükséges az átalakulás végleges eldöntéséhez, ${ }^{640}$ ezeknél ruházhatja át részesedését.

Mindemellett „az sem lehetetlen, hogy a második „ügydöntő” legfőbb szervi ülésen olyan új körülmények merülnek fel (például valamely tag meghal vagy meggondolja magát), amely miatt a vagyonmérleg-tervezetek adatrendszere felborul, vagy más okból kiegészítő vizsgálódás szükséges." ${ }^{641}$

Természetesen abban a hipotetikus esetben, ha az örökhagyó az átalakulás mellett döntött, az örökösök pedig még a cégbíróság eljárása folyamán a (jogelőd) társaság tagjaivá váltak, az új, örökösként belépett tagok is egyetértenek az átalakulás szükségességében és a többi kérdésben is (pl. a vagyonelosztásban, ha van kilépő tag), a cégbíróság pedig a kérelmet helybenhagyja, azaz az átalakulás bejegyzésre kerül, az új társaságban az örökösök szintén taggá válnak annak cégjegyzékbeli bejegyzésével. Itt is érdemes arra emlékezni, hogy a hagyatéki eljárások nem fejeződnek be olyan gyorsan, hogy az átalakulási eljárás ideje alatt beléphessenek az örökösök az esetleges akaratuknak megfelelően. Így az átalakulás bejegyzésére akkor is sor kerülhet, ha az örökösök érdekeivel ellentétes.

Ezen túlmenően az is kérdéses, hogy az örökösök mennyire vannak tisztában az örökhagyó tevékenységével, akkor pedig kifejezetten problémás, ha nem álltak szoros kapcsolatban az örökhagyóval. Amennyiben egyáltalán tudomásuk van arról, hogy valamely gazdasági társaság tagja volt, akkor sem biztos, hogy tudják, melyikben, illetve nem tudják a társaság elérhetőségét, így nem tudják értesíteni a tag haláláról az érintett gazdasági társaság vezető tisztségviselőjét, mindez azt vonja maga után, hogy az átalakulási eljárásról sem lesz tudomásuk.

\footnotetext{
${ }^{639}$ Ptk. 3:143. § (4) bek.

${ }^{640}$ Ptk. 3:43. § (1) bek.

${ }^{641}$ Gál - Adorján 64.
} 
Az átalakulási eljárás egyes üléseire szóló meghívókkal kapcsolatban hasonló helyzet következhet be: egyáltalán nem, vagy csak jelentős késéssel veszik át az örökösök ezeket a küldeményeket, például azért, mert nem egy háztartásban laktak. A kézbesítési vélelem beállásával ${ }^{642}$ pedig az ülésen való meg nem jelenés következtében a részvételi arány csökken, adott esetben nem tudnak szavazni az átalakulásról. Érdemes megfontolni, hogy jelentősebb társasági részesedéssel rendelkező tag jelen nem léte miatt a döntéshozó szervi ülés egyáltalán nem is lesz határozatképes, ${ }^{643}$ éppen ezért újabb ülést kell tartani.

A társaságtól megválni kívánó tag halálával örököseinek is lehetőségük van a vagyonhányad megszerzésére, ez a vagyoni igény őket is megilleti, ez olyan, a társasággal szemben fennálló jog, ami az örökhagyó halálával átszáll a jogutódokra.

\subsubsection{Együléses eljárás}

Az Átv. 8. § (1) bekezdése szerint, ha az ügyvezetés megfelelően előkészítette az átalakuláshoz szükséges okiratokat, a legföbb szerv egy ülésen szavazhat az átalakulásról. Erre csekélyebb taglétszámú és egymással szoros kapcsolatban müködő tagok esetén kerülhet sor, amikor informális úton szerzett információk alapján megtörténhet az átalakuláshoz szükséges dokumentumok elkészítése. Egyszerübb átalakulásoknál ugyanis felesleges adminisztratív teher lehet a két ülés megtartása, a törvény ezért teszi lehetővé az egy ülésen történő határozathozatalt is. ${ }^{644}$ Az öröklés átalakulási eljárásra gyakorolt hatása tekintetében csekély különbség jelentkezik az együléses és a kétüléses döntéshozatal között: a kétüléses felállásban a második ülés végéig kell döntenie a tagnak, részt kíván-e venni az átalakulásban, míg egy ülés esetén ezt eddig az ülésig kell eldönteni véglegesen. Ha még ebben a szakaszban hal meg a tag, a társaság többi tagjának, amennyiben lehetőségük van rá a szűkös határidők miatt, érdemes megvárnia, amíg az örökösök nyilatkoznak arról közkereseti és betéti társaság esetén, be kívánnak-e lépni, és miután az örökös és a társaság közötti megegyezésnek kell születnie, e tekintetben is siettethetik a belépést, ha az örököst a társaság tagjai között kívánják tudni. Korlátolt felelősségű társaság vonatkozásában automatikusabb jogutódlásról van szó; ezt az ipso iure jelleget befolyásolhatja az, hogy a Ptk. alapján az

\footnotetext{
${ }^{642}$ Ptk. 3:91. § (4) bek.

${ }^{643}$ Ptk. 3:18. § (1) bek. ${ }^{644}$ Uo.
} 
üzletrész megváltására jogosult személyek magukhoz kívánják váltani azt. ${ }^{645}$ Ameddig a jogutódlás vagy a megváltás nem történik meg, az átalakulásról sem dönthetnek anélkül, hogy esetleg az örökösök érdekei ne sérülnének.

Kérdésként veti fel a határidők vonatkozásában a PJD 2016. 12. döntés, miszerint igazolni kell-e, hogy a meghívó kézbesítése szabályszerüen megtörtént, illetve annak tartalmáról a tag tudomást szerzett. A kft.-k vonatkozásában a Ptk. 3:190. § (1) bekezdése, a több társasági forma vonatkozásában a 3:17. § a meghívók meghatározott időn belül történő megküldéséhez füz jogkövetkezményt. Eszerint a taggyülés akkor tekinthető - a jogszabályban elöírt egyéb feltételek megvalósulása mellett szabályszerüen összehívottnak, ha a tag részére szóló meghívó a cégnyilvántartásban bejegyzett lakhelyre, jogi személyek esetén székhelyre - esetlegesen a központi ügyintézés helyére - megküldésre került. A meghívó lakhelyre határidőn belül történő megküldésén túl a Ptk. nem ír elő egyéb kötelezettséget, így nem várható el, hogy a társaság felkutassa a tag cégjegyzékbe bejegyzettől eltérő tényleges lakhelyét, székhelyét. A részvénytársaság vonatkozásában az általános szabályokhoz képest szintén találunk speciális rendelkezéseket, így többek között a meghívó vonatkozásában az általános tartalmi elemeken túlmenően tartalmaznia kell a közgyülés megtartásának módját, a szavazati jog gyakorlásához az alapszabályban előírt feltételeket, valamint a közgyülés határozatképtelenséges esetén a megismételt közgyülés helyét és idejét. ${ }^{646}$ Mindezeken túlmenően további szabályok vonatkoznak a közgyülés összehívására zártkörüen ${ }^{647}$ és nyilvánosan müködő részvénytársaságoknál, ${ }^{648}$ ahogy a törvény meghatározza a közgyülés összehívásának kötelező eseteit, amelyek a társaság vagyoncsökkenésével függnek össze, és a részvényeseknek olyan döntést kell hozni, ami alkalmas ennek a megszüntetésére, vagy dönteniük kell a társaság átalakulásáról, egyesüléséről, szétválásáról vagy megszüntetéséről. ${ }^{649} \mathrm{E}$ szabályok figyelembevétele szükséges abban az esetben is, ha valamely tag, illetve részvényes elhunytáról a társaság még nem szerzett tudomást, így hiába keresi őt a meghívó szabályszerü megküldésével a társaság a taggyülés, illetve közgyülés megtartása érdekében, a társaság müködőképességét biztosítani kell.

\footnotetext{
${ }^{645}$ Ptk. 3:170. § (2) bek.

${ }^{646}$ Ptk. Ptk. 3:269. $\S$

${ }^{647}$ Ptk. 3:271. §

${ }^{648}$ Ptk. 3:272. §

${ }^{649}$ Ptk. 3:270. §
} 


\subsubsection{A gazdasági társaságok egyesülése}

A gazdasági társaságok egyesülése összeolvadás és beolvadás útján történhet. Összeolvadásnál az összeolvadó jogi személyek megszünnek, és új jogi személy jön létre általános jogutódlás mellett. Beolvadásnál a beolvadó jogi személy szünik meg, általános jogutódja az egyesülésben részt vevő másik jogi személy. ${ }^{650}$

A 2007. évi CXL. törvény 3. § (1) bekezdése határozza meg az egyesülési szerződés közös tervezetének elemeit, amelyek közül a b) tartalmazza azt, hogy idetartozik az egyesülés útján létrejövő társaság részesedéseinek átruházására vonatkozó részletes szabályok is. Ebbe a pontba beleérthetők mindazok, amelyek akár az átruházás korlátozása, akár annak kizárása vonatkozásában felmerültek az öröklési szerződés kapcsán.

Nem feltétel az, hogy csak az a személy lehet valamely jogutód társaság tagja, aki már eleve valamely jogelődben tag volt, az egyesülési eljárás folyamán más személy is csatlakozhat. Az örökhagyónak is fennállhatott az a szándéka, hogy a jogutód társaság tagjává váljon, amíg azonban ez nem nyilvánul meg valamilyen jogilag értékelhető formában, az örököseinek sem lenne lehetőségük a jogutód tagjává válni. Ilyen forma lehetne például az előszerződés, amelyben jelen esetben arra vállalkoznának az azt megkötő felek, hogy az örökhagyó a tagsági jogviszonyát az új jogi személyben is fenn kívánja tartani vagy éppen tagsági jogviszonyt szeretne létesíteni. Ennek módja lehet szindikátusi szerződés is, amelynek létezik olyan válfaja, ami szándéknyilatkozat jelleggel bír, azaz ebben csak a társaság alapításában való szándékot mérik fel, egy másik típusa lehet az említett előszerződés jellegü, ami viszont egyébként már társaságalapítási kötelezettséget keletkeztet. ${ }^{651} \mathrm{Ez}$ a kötelem azonban az örökhagyó halálával megszünik: az örökösök személye meghatározott ideig bizonytalan, kérdéses az is, hogy az egyesülési eljárás folyamán az örökhagyó halála után bekövetkezett-e olyan, a társasággal kapcsolatos változás (pl. jelentős társasági vagyonvesztés), aminek hatására, ha még ekkor élne az örökhagyó, mégse szeretett volna taggá válni, tehát ő is szabadult volna ettől az előszerződéstől. Ennek az előszerződésnek a személyes jellege nem mérhető össze más kötelmek személyes mivoltával, ami miatt jogutódlásnak lenne helye az örökhagyó pozíciójában. Az örökhagyói szándék nem jelent speciális képességet, az pusztán egy akaratnyilatkozat, a

\footnotetext{
${ }^{650}$ Ptk. 3:44. §

${ }^{651}$ Papp 2015. 229.
} 
társaságok eredeti alapítása vonatkozásában is - amelynek a szabályait alkalmazni kell a származtatott alapításra is - mindenki a maga személyében dönt, aláírja-e a társasági szerződést, ekkor taggá válik, vagy nem írja alá, ekkor nem lesz tag. Emellett a vállalt vagyoni hozzájárulást is teljesíteni kell. A társaság alapításában, illetve abban való részvételre nem lehet senkit sem kényszeríteni, ez igaz lesz az egyesülési eljárás során létrejövő gazdasági társaság vonatkozásában is. Egy ilyen előszerződésben nem lehet továbbvinni a személyesen vállalt kötelezettséget, a kérdésre a kötelmi jogi és társasági jogi szabályokat együttesen kell alkalmazni.

\subsubsection{A jogi személyek szétválása}

A jogi személy különválás vagy kiválás útján több jogi személlyé szétválhat. Különválás esetén a jogi személy megszünik, és vagyona a különválással létrejövő több jogi személyre, mint jogutódra száll át. Kiválás esetén a jogi személy fennmarad, és vagyonának egy része a kiválással létrejövő jogi személyre, mint jogutódra száll át.

A szétválás úgy is megvalósítható, hogy

a) a kiváló tag a jogi személy vagyonának egy részével már müködő jogi személyhez, mint jogutódhoz csatlakozik (beolvadásos kiválás), vagy

b) a különváló tagok a jogi személy vagyonának rájuk eső részével különböző, már müködő jogi személyekhez, mint jogutódokhoz csatlakoznak (beolvadásos különválás). ${ }^{652}$

A többszintű szabályozási struktúra alapján az Átv. 17. § (1) bekezdése szerint a szétválásra a jogi személyek átalakulásának, valamint egyesülésének közös szabályai a törvényben foglalt eltérésekkel megfelelöen irányadóak. Ez a rész olyan rendelkezéseket is tartalmaz, amelyek egyrészt a korábbiak megismétlése, illetve ezekből levezethetőek, így például az, hogy a szétválási terv elfogadásáról vagy módosításáról a szétváló jogi személy döntéshozó szerve dönt. Ezek alapul vételével a törvény szétválás esetén is, az egyesüléshez hasonlóan, bizonyos többletszabályokat határoz meg az eljárás sajátosságaira figyelemmel: a szétválási szerződést a szétváló jogi személy tagjai, valamint a jogutód jogi személyek tagjai (leendő tagjai) kötik meg egymással és írják alá. A jogutód új jogi személy létesítő okiratát csak azok a tagok írják alá, akik az adott jogutód tagjaivá válnak. ${ }^{653}$ Ezek a szabályok a szétválási

${ }^{652}$ Ptk. 3:45. § (1)-(2) bek.

653 Átv. 18. § (4)-(5) bek. 
eljárásban elfoglalt időbeli elhelyezkedésüknél fogva az örökhagyó cselekményeihez (a szétválásról szóló döntés, szétválási szerződés aláírása) tartozhatnak. Amennyiben még nem jut cégbírósági szakig a szétválás, azaz még a szétválásról folyó tárgyalások alatt meghal a tag, szintén minél hamarabb rendezni kell a tag utáni öröklés, valamint a társaságbeli pozíciójában történő változás folytán támadt jogi helyzetet, azért, hogy folytathassák az eljárást.

\subsection{Az osztrák szabályozás alapjai}

A származtatott alapítás osztrák szabályozásának jogrendszerbeli elhelyezkedése a magyar joganyaghoz hasonlóan rendkívül nagy heterogenitást mutat. A személyegyesítő társaságokra vonatkozó szabályokat az UGB tartalmazza, míg a tőkeegyesítő társaságokra irányadó rendelkezések több helyen lelhetők fel: a GmbHG bizonyos részletszabályok mellett a kft.-k egyesülésére az Aktiengesetz részvénytársaságok egyesülési szabályait rendeli alkalmazni megfelelő alkalmazással, ebböl következik, hogy a részvénytársaságoknál az Aktiengesetz-et kell figyelembe venni. A tőkeegyesítő társaságok szétválásának részletszabályait a Spaltungsgesetz taglalja, míg e típusú társaságok átalakulására az Umwandlungsgesetz (UmwG), valamint az Aktiengesetz alkalmazandó.

A tőkeegyesítő társaság átalakulhat egyetemleges jogutódlással közkereseti, illetve betéti társasággá, ${ }^{654}$ míg az is átalakulásnak számít, ha a legalább a törzstőkéböl, valamint alaptőkéből 90\%-os részesedéssel rendelkező tag átveszi a teljes vállalatot, amennyiben a legfőbb szerv így döntött. Ekkor a társaságot törlik a cégjegyzékből, az átvevő tag pedig az UGB rendelkezéseinek betartásával használhatja az addigi céget. ${ }^{655}$ Amennyiben ez a döntés megszületett, és ez a többségi tag ezután meghal, úgy örökösei ezt a vállalkozást vihetik tovább. Ha még csak a taggyülésre, közgyülésre vonatkozó meghívó került kiküldésre, akkor ez a többségi hányad a társaságnak megfelelő jogutódlás alapján az örökösökre háramlik, ha ez közöttük felosztásra kerül, nem is lesz meg ez a szükséges többség.

Az átalakulás másik esete az, ha valamely személyegyesítő társasággá válik a tőkeegyesítő társaság, amely utóbbiban szükség van arra, hogy a tőkeegyesítő társaság vagyonának 90\%-ával rendelkező tagok váljanak taggá, a maradék egytized részt

\footnotetext{
${ }^{654} \mathrm{UmwG} 1 . \S$

${ }^{655} \mathrm{UmwG}$ 2. § (2) bek. 2. pont, UmwG 4. §, UGB 22. §
} 
szerezhetik meg csak új tagok. ${ }^{656}$ Ebben az esetben a taggá vált örökösöket is megilleti ez az átalakulás mellett való döntés joga, de csak akkor, ha megvan a szükséges szavazattöbbség.

Átalakulás a hagyományos értelemben vett társasági forma megváltoztatása, amelynek egyes szabályait - korlátolt felelősségű társaságból részvénytársaság, ${ }^{657}$ és fordítva $^{658}$ is - a részvénytársaságokra irányadó törvény tartalmazza. Ezeknél a fontosabb rendelkezések közé a részvények kiállításának, illetve azok cseréjének részletszabályai tartoznak.

A kft.-k egyesülése megvalósulhat összeolvadással és beolvadással, ${ }^{659}$ amely legalább háromnegyedes szavazattöbbség kell, azzal, hogy a társasági szerződésben további feltételeket is meghatározhatnak. ${ }^{660}$ Amennyiben a társasági szerződésben nem rendelkeztek megváltási jogról, és az örökösök megszerezték az elhunyt üzletrészét, meglátásom szerint rájuk is igaz a magyar joghoz hasonlatosan, dönthetnek az egyesülés folytatása mellett. Ha megfelelő többség áll rendelkezésükre, meg is szüntethetik az eljárást az adott társaságra vonatkozóan.

A részvénytársaságok is egyesülhetnek mind beolvadással, mind összeolvadással. ${ }^{661}$ A téma szempontjából kevésbé jelentős eltérés az, hogy a részvénytársaság korlátolt felelősségű társasággal is egyesülhet, ${ }^{662}$ az előbbi örökléssel kapcsolatos megállapítások igazak lesznek.

A tőkeegyesítő társaságok szétválása a magyar jogból is ismert módokon valósulhat meg: kiválás beolvadással, kiválás új társaság alapításával, különválás beolvadással, különválás új társaság alapításával, ${ }^{663}$ ezek öröklési jogi vetületeire szintén a már említetteket kell megfelelően alkalmazni.

\section{6. Összegző gondolatok}

Megállapítható, hogy a gazdasági társaságok származtatott alapításának mindegyik eseténél (átalakulás, egyesülés, szétválás) relevanciával bír valamely társaság tagjának halála, adott esetben magának az eljárásnak a végét is jelentheti. A tag

\footnotetext{
${ }^{656}$ UmwG 5. § (1) bek.

${ }^{657}$ AktG 245-253. §

${ }^{658} \mathrm{AktG} 239-244$. §

${ }^{659}$ GmbHG 96. § (1) bek.

${ }^{660} \mathrm{GmbHG} 98 . \S$

661 AktG 219. §

${ }^{662} \mathrm{AktG} 234$. §

${ }^{663}$ SpaltG 1. § (2) bek.
} 
halála egyben a jogviszonyának megszünését jelenti, ezen átfogó kategóriának az átalakulás folyamatára gyakorolt hatásáról a jogalkotónak érdemes szabályt alkotnia. Álláspontom szerint abban az esetben, ha az átalakulási (egyesülési, szétválási) eljárás bármely szakasza alatt (egészen a cégbírósági bejegyzésig) megszűnik a tagsági jogviszony, és abban jogutódlás várható (pl. társasági részesedés átruházása, öröklés) célszerü lenne a Ctv.-ben megadni a társaságnak azt a lehetőséget, hogy - bizonyos körülmények, így például valamely tag halálának bekövetkeztekor - az eljárást a társaság felfüggeszthesse, azért, hogy a jogutód nyilatkozatának megfelelöen folytathassák vagy befejezhessék az eljárást. A jogutód nyilatkozatát pedig akkor lehetne elfogadni, amennyiben az jogerős hagyatékátadó végzésen, jogerős öröklési perben hozott ítéleten alapul, de legalábbis örökösi minőségének igazolására öröklési bizonyítványt kell tőle megkövetelni.

Figyelembe kell venni ugyanakkor azt is, nem biztos az, hogy maga az átalakulni kívánó gazdasági társaság tudomást szerez tagjának haláláról, aminek folytán a további szükséges lépéseket sem teheti meg. Elképzelhető az, hogy az örökösök nem tudnak arról, hogy az örökhagyó valamely társaság tagja volt, vagy ha tudják is, a társaság értesítése elmarad. Ekkor meg kell vizsgálni azt is, mennyiben beszélhetünk automatikus jogutódlásról. Az örökösök jogai kevésbé sérülhetnek egy általuk nem kívánt átalakulással, miután a legtöbb társaságnál kérelmezni kell azt, hogy taggá válhassanak, az ilyen kérelmeknél pedig az örökös érdeke a megfelelő tájékoztatás kérése a társaság helyzetével kapcsolatban, ennek a tájékoztatásnak a társaság részéről ki kell terjednie az esetleges átalakulásra is, az örökös pedig ennek tudatában dönthet az abban való részvételről vagy távolmaradásról. 


\section{A közös veszélyben elhunyt társasági tagok utáni jogutódlás rendezése}

\subsection{Bevezetés}

Az öröklés előfeltételeit a törvényi szabályozás ${ }^{664}$ és a jogtudomány ${ }^{665}$ megfelelően kidolgozta, ezek közé sorolható az, hogy az örökös nem eshet ki az öröklésből. Kiesésnek minősül, ha az örökös nem éli túl az örökhagyót. ${ }^{666}$ „A hagyatékot tehát az sem szerezheti meg, aki nem az örökhagyó előtt, hanem az örökhagyóval egyidejüleg hal meg, hiszen az ő jogképessége pontosan akkor szünik meg, amikor öröklés jogcímén jogokat szerezne, márpedig aki nem jogképes, az jogot öröklés jogcímén sem szerezhet. A helyes fogalmazás tehát a régi Ptk.-tól eltérően a Ptk.-nak megfelelö." ${ }^{667}$

A gyakran elöforduló, több ember életét követelő balesetekben elhunytak egymás utáni öröklésének rendezésére a régi Ptk.-hoz képest a hatályos Polgári Törvénykönyv már tartalmaz szabályt: a közös balesetben vagy más hasonló közös veszélyhelyzetben elhunyt személyek az egymás után történő öröklés tekintetében a halál beálltának sorrendjétől függetlenül kiesettnek tekintendők. ${ }^{668}$

E szabálynak a megjelenését napjaink felgyorsult technikai fejlődésével, a motorizáció rendkívüli térhódításával indokolta a jogalkotó. ${ }^{669}$ Gyakran előforduló eset az, hogy egy család tagjait (szülők, gyermekek) végzetes baleset éri, és nem lényegtelen kérdés az, miképp megy végbe az öröklés e személyek után, mert a különböző szabályok igencsak eltérő megoldásokhoz vezethetnek.

\footnotetext{
${ }^{664}$ Ptk. 7:4. §

665 Az öröklés előfeltételeit vö. Vékás 2014b. 21-33.

${ }^{666}$ Ptk. 7:4. §

${ }^{667}$ Anka 2013. 158.

${ }^{668}$ Ptk. 7:4. $\S(1)$ bek.

${ }^{669}$ T/7971. számú törvényjavaslat a Polgári Törvénykönyvröl indokolásából, Orosz 2014c. 219.
} 


\subsection{A közös veszélyben elhunytak utáni öröklés rendezésének lehetséges változatai}

\subsubsection{A három út}

A közös veszélyben elhunytak utáni öröklésre vonatkozóan három szabályozási mód figyelhető meg az európai megoldások alapján. Ezek közül valójában csak kettő változat jelenti a kérdés rendezését, a harmadik nem jelent valódi megoldást.

\subsubsection{A fizikai ellenálló képességen alapuló vélelmek}

A közös veszélyben elhunytak utáni öröklés rendezésének igénye már az ókori Rómában is jelentkezett. A fellelhető források például háborúban elesett katonák (apafia), valamint különböző utazási (hajó) szerencsétlenségek miatt elhunyt emberek (anya és csecsemő fia) utáni öröklésről tesznek említést. Azonos ezekben az esetekben - ami a mai viszonyokra is igaz -, olyan személyek utáni/közötti öröklési viszonyokra igyekeztek szabályt felállítani, akik egymás rokonai, de legalábbis az egyikük örököl a másik halála esetén. Ennek hiányában lényegtelen lenne a haláluk sorrendjének bárminemű meghatározására tett kísérlet. A források áttekintése alapján megállapítható, hogy közös veszélyben elhunytak esetén sok esetben nem az örökhagyó vérszerinti rokonai, hanem házastársa, illetve annak rokonai örökölnének. A vérszerinti rokonok peres ügyeiben a jogtudósok e helyzetek kiküszöbölésére igyekeztek megoldást találni. ${ }^{670}$ A posztklasszikus korra a római jogtudósok vélelmezték, hogy a serdületlen gyermek a szülő előtt hal meg, serdült gyermek és szülő közül viszont a szülő hal meg hamarabb, míg nő és férfi közül előbb a nő veszíti életét.

A probléma modernkori megoldására egészen a XVIII-XIX. századig várni kellett. A római joghoz hasonló megoldással az 1804-es Code Civil él. Eszerint a 15 év alatti elhunytaknál az idősebb éli túl a másikat, 60 felettieknél a fiatalabb, míg ha az egyik elhalt személy 15 év alatti és a másik pedig 60 év feletti, akkor a fiatalabbat kell a másikhoz képest túlélőnek tekinteni. 15-60 év közötti személyek esetében pedig nem a vélhető fizikai ellenálló képességre alapoz, hanem fő szabály szerint különböző neműek esetén a férfi a túlélő, azonos neműek esetében ,az örökséghez jutásuk természetes sorrendjét véve alapul a fiatalabbat kell túlélőnek tekinteni." ${ }^{\text {671 }}$

\footnotetext{
${ }^{670}$ Nótári - Papp 2004. 16-17., Hamza - Sajó 192.

${ }^{671}$ Nótári - Papp 2004. 13.
} 
Ezeket a szabályokat az általános biológiai tapasztalatok hatására alkották meg, de az iskolapéldának számító felvetés szerint ${ }^{672}$ egy repülőgép-szerencsétlenségben elhunyt házaspár halálának sorrendjénél aligha számít az, hogy a férj cirkuszi erőművész. Meg kell azt említeni, hogy ,a Code Civil rendszerében ez a törvényi vélelem azonban csak szubszidiárius jellegü, vagyis csak akkor alkalmazható, ha ténylegesen nem állapítható meg, hogy a kölcsönösen öröklésre jogosultak közül, akik egyazon eseményben (événement) pusztultak el, melyik hunyt el később."673

Ehhez a megoldáshoz sorolható még az 1925-ös brit Law of Property Act rendelkezése is, amely szerint, ha olyan körülmény áll be, ami miatt nem lehet megállapítani a halál sorrendjét, a fiatalabbat kell a túlélőnek tekinteni. ${ }^{674}$

\subsubsection{Az egyszerre elhalás vélelmezése}

A második megoldási variáció legjobb példáinak az osztrák Todeserklärungsgesetz (holttá nyilvánítási törvény) és a német Verschollenheitsgesetz (eltünési törvény) számítanak. Mindkét törvény 11. §-a ugyanúgy rendelkezik: „Kann nicht bewiesen werden, dass von mehreren gestorbenen oder für tot erklärten Menschen der eine die anderen überlebt hat, so wird vermutet, dass sie gleichzeitig gestorben sind." Azaz ha nem lehet megállapítani, hogy több elhalt vagy holttá nyilvánított személy közül egyik a másikat túlélte-e, úgy kell tekinteni, hogy egyszerre haltak meg. A német-osztrák szabályozásból kiemelést érdemel: a szabály alkalmazása arra az esetre vonatkozik, ha az elhalálozás sorrendje bizonytalan, azt nem tudják bizonyítani, ${ }^{675}$ ezzel ellentétben a magyar meg sem adja a lehetőséget a bizonyításra, a jogkövetkezmény az, hogy az egymás utáni öröklés szempontjából azonnali kiesést von maga után. ${ }^{676}$ A két külföldi törvény nem utal arra, hogy csak az egymás utáni öröklésre vonatkozna-e, továbbá lényegtelen, hogy az érintett személyek halálának időpontjából csak az egyik vagy egyik sem ismert, alkalmazni kell ezt a szabályt. ${ }^{677}$ Ennek indokát abban kell keresni, hogy a német BGB 1923. § (1) bekezdésében meghatározott öröklési képesség fogalmát ${ }^{678}$ alapul véve csak az válhat örökössé, aki a halálesetkor életben van. ${ }^{679} \mathrm{Ez}$

\footnotetext{
${ }^{672}$ Nótári - Papp 2004. 13., Hamza-Sajó 194.

${ }^{673}$ Hamza - Sajó 193.

${ }^{674}$ Hamza - Sajó 197.

${ }^{675}$ Burandt - Rojahn 1287.

${ }^{676}$ Ptk. 7:4. $\S(1)$ bek.

${ }^{677}$ Burandt - Rojahn 1287-1288.

${ }^{678}$ Erbe kann nur werden, wer zur Zeit des Erbfalls lebt.

${ }^{679}$ Vö. Burandt - Rojahn 1288.
} 
összecseng a Ptk. 7:4. § (1) bekezdésében található alapesettel: kiesik az öröklésből, aki nem éli túl az örökhagyót, tehát nem esik ki az öröklésböl, így örökös lesz az, aki túléli őt. A német szabályozással teljesen megegyező megoldással élnek a svájciak is. ${ }^{680} \mathrm{~A}$ svájci Zivilgesetzbuch 32. § (2) bekezdése csak szóhasználatában tér el a német és az osztrák megfogalmazástól, ${ }^{681}$ amellyel kapcsolatban érdekességként megjegyezhető, hogy a szabályt nem az öröklési jog, hanem a személyek jogának szabályai között találhatjuk meg.

A holland Ptk., a Burgerlijk Wetboek 4. könyvének 2. cikkelye ${ }^{682}$ azt a vélelmet állítja fel, miszerint ha két vagy több személy elhalálozásának sorrendje nem állapítható meg, úgy kell tekinteni őket, mint akik egyszerre haltak meg, azaz egyikük hagyatékából semmilyen előny nem származik a másikra nézve. A vélelem azonban megdönthető, ugyanezen cikkely (2) bekezdése szerint ugyanis a bíróság akár többszöri haladékot is adhat annak az érdekeltnek, aki neki nem felróható nehézségek miatt akadályozott a közös veszélyben elhaltak közötti halálozási sorrend bizonyításában, feltéve, hogy ésszerüen feltehető, hogy a bizonyítás a haladék elteltéig lehetségessé válik. ${ }^{683}$ Azaz, ha nem lehet megállapítani a haláluk sorrendjét, akkor nem egy törvényi sorrendet állít fel, hanem a hatályos magyar jogszabályhoz hasonlóan egyszerre kiesést állapít meg. A szubszidiaritást nemcsak a korábban említett francia, illetve holland jog ismeri, hanem további európai példaként említhetjük meg a fentebb leírt svájci jogot is. $^{684}$

Az öröklési jog újdonsága az Európai Unió öröklési rendelete, amelynek a határon átnyúló elemeket tartalmazó öröklés teljes körü rendezése mellett egyik célkitűzése volt az öröklést tekintve eltérő joga hatálya alá tartozó közös eseményben, a magyar Ptk.-beli terminológiával élve közös veszélyhelyzetben elhunyt személyek utáni helyzet tisztázása. Az öröklési rendelet alapján az olyan esetek egységes kezelését szerették volna biztosítani, amelyekben bizonyossággal nem lehet megállapítani, hogy két vagy több, az öröklést tekintve eltérő jog hatálya alá tartozó személy halála milyen sorrendben következett be, ${ }^{685}$ ezért mondja ki a 32 . cikk, amennyiben e jogok

\footnotetext{
${ }^{680}$ Pardy

681 „Kann nicht bewiesen werden, dass von mehreren gestorbenen Personen die eine die andere überlebt habe, so gelten sie als gleichzeitig gestorben."

${ }^{682} \mathrm{http}: / /$ www.wetboek-online.nl/wet/Burgerlijk\%20Wetboek\%20Boek\%204.html (2017.07.21.)

${ }^{683}$ Csizmazia 30.

${ }^{684}$ ZGB 32. § (1) bek.: Wer zur Ausübung eines Rechtes sich darauf beruft, dass eine Person lebe oder gestorben sei oder zu einer bestimmten Zeit gelebt oder eine andere Person überlebt habe, hat hiefür den Beweis zu erbringen.

685 55. preambulum-bekezdés
} 
különböző módon rendelkeznek, vagy egyáltalán nem rendelkeznek erröl a helyzetről, ezen elhalálozott személyek egyikét sem illetik meg jogok a másik vagy a többi utáni öröklésben.

Tehát amennyiben közös veszélyben elhunytakról van szó, és az öröklési rendelet alapján ugyanazon jog hatálya alá tartoznak, ez a jog lesz irányadó az öröklés vonatkozásában, bármelyik rendezési módot is követi. Viszont ha más államok jogát kell alkalmazni, először azt kell megvizsgálni, hogy a kérdés rendezésében összeegyeztethetőek-e egymással, ha ez nem teljesül, akkor arra az esetre kell alkalmazni a 32. cikket, a jogkövetkezmény végső soron ugyanaz lesz, mint a magyar jogban: az érintett személyeket egymás utáni öröklésüket tekintve úgy kell tekinteni, mint ha nem is léteztek volna, ${ }^{686}$ azaz kiestek.

Mindezekre tekintettel a magyar, a német, illetve az osztrák vélelem összeegyeztethető az öröklési rendelettel. ${ }^{687}$

\subsubsection{A kódex hallgatása}

A harmadik út, ami tulajdonképpen nem minősül megoldásnak, az a jogi helyzet, ami a régi Ptk.-ban is volt: a jog nem ad semmilyen vélelmet e tárgykörben, hallgat erről az esetről. Ekkor csupán az öröklésben érdekeltek bizonyításán múlik a halál sorrendjének megállapítása, ami igazságtalan eredményekhez is vezethet. ${ }^{688} \mathrm{Az} 1959$. évi IV. törvény miniszteri indokolása szerint miután „nincs vélelem az élveszületés, a születések sorrendje, valamint az életbenlét mellett sem, ugyanúgy nincs a halál tényére, valamint annak időpontjára sem. Ilyen sorrend megállapítása ugyanis megnehezítené a jogviszonyok megfelelő rendezését; bizonyos esetekben még a vélelem megdöntésének lehetősége sem enyhítene számottevően a vélelemből eredő kötöttségen."689 Meglátásunk szerint helyesen járt el a jogalkotó, amikor változtatott ezen az állásponton, és bevezette az új szabályt.

\footnotetext{
${ }^{686}$ Lagarde 181-182.; Müller-Lukoschek 77.; Köhler 1611-1612.; Fischer-Czermak 306-308., Weber $277-$ 280.

${ }^{687}$ Vö. Burandt - Rojahn 1450; Müller-Lukoschek 77.

${ }^{688}$ Ehhez kapcsolódóan különbözö esetvariációkat mutat be Nótári - Papp 2004. 19-22.

${ }^{689}$ régi Ptk. indokolása 39.
} 


\subsubsection{A közös veszély szabályozásának elsö megjelenése a magyar jogban}

„Törvényes vélelmet a magyar jog sem az élveszületés, sem a közös veszedelemben elhaltak halálának sorrendje tekintetében nem ismer" írta már Szladits Károly 1933-as munkájában. ${ }^{600}$ A magánjogi kodifikációs munkálatok során a Hoffman Pál által készített 1871. évi Általános Magánjogi Törvénykönyv Tervezet személyekre vonatkozó részének 31. §-a állította fel elöször azt a vélelmet, miszerint egy idöben haláloztak el a több ugyanazon halálveszélyben kimúlt személyek. ${ }^{691}$ Az 1900-as tervezet ${ }^{692}$ Lányi Bertalan által írt személyjogi részének 15 . §-a is ezt vélelmezte. Egyetértett ezzel az állásponttal a kolozsvári egyetem professzora, Haller Károly is. Véleménye szerint nem tesz eleget a törvényes szabályozás követelményének az, ha az öröklésben érdekeltre hagyják a halálozás sorrendjének bizonyítását. Példaként állítja egy házaspár halálát, akik közül „a szakértők valamelyiknek korábbi halálát valószínünek tartják, de azt határozottan nem állíthatják, ebben az esetben a bíró helyzete meg lenne nehezítve. ${ }^{, 693} \mathrm{Az}$ 1913. évi magánjogi törvénytervezet ${ }^{694} 18$. §-a is az egy időben való halált vélelmezte, a javaslathoz füzött indokolás szerint továbbra is a bizonyítási nehézségek elkerülése érdekében. ${ }^{695}$ Ehhez képest az 1928-as Magánjogi Törvénykönyv javaslatában ilyen szabály nem szerepel, abszolút a felek bizonyítására alapozza a helyzet rendezését. ${ }^{696}$ Vélhetően ennél a nézetnél maradva döntöttek 1959ben is bárminemü vélelem (sorrend felállitása, egyszerre kiesés) hiányáról.

\subsubsection{A közös veszély a hatályos magyar szabályozás szerint}

A Ptk. elfogadásakor végül a közös veszélyhelyzetben elhunyt személyek utáni öröklés tekintetében vélelem felállitása mellett törtek lándzsát. Ez a vélelem nem a halál sorrendjére vonatkozóan tartalmaz rendelkezést, hanem átvágva a gordiuszi csomót (követve ezzel a német jogi hagyományokat), a közös balesetben vagy más hasonló közös veszélyhelyzetben elhunyt személyeket az egymás után történő öröklés tekintetében a halál beálltának sorrendjétöl függetlenül kiesettnek kell tekinteni. Ezzel

\footnotetext{
${ }^{690}$ Szladits 60.

691 1871-es tervezet

6921900 -as tervezet 4.

693 1900-as tervezet bírálata 43.

${ }^{694}$ Hamza - Sajó 198.

695 1914-es tervezet indokolása

${ }^{696}$ Hamza - Sajó 198.
} 
az új szabállyal remélhetőleg kiküszöbölhetőek lesznek a kodifikátorok által is észlelt anomáliák. $^{697}$

Nem a kiesési okok köre, hanem a kiesésre vonatkozó szabályok bővültek. ${ }^{698}$ Kétségtelen, hogy akkor minősülnek egyszerre kiesetteknek az ilyen körülmények között elhaltak, ha legalább szoros időbeli kapcsolat van a haláluk között, de az egyidejüség valószínüsége nagyon kicsi. Osztom azt az álláspontot, miszerint a bírói gyakorlatra vár annak tisztázása is, hogy azon személyek körében hogyan állapítja meg az egyszerre kiesettséget, akik egy baleset miatt, de egyértelmüen időben jól elkülöníthetően haltak meg. Ebből a szempontból a német megoldás nem lenne maradéktalanul alkalmazható, hiszen ilyen esetben bizonyíthatóan meg lehetne állapítani a halál sorrendjét, így a vélelem alkalmazására nincs szükség. Még nehezebb kérdés az, hogy használják-e a vélelmet akkor, ha ugyanabban a veszélyhelyzetben, de egymástól térbeli különbséggel (pl. az egész Balatonra kiterjedő viharban) hunytak el. ${ }^{699}$ Önmagában a közös veszélyhelyzet megfogalmazás is problémás, nem teljesen mentes az aggályoktól. E fogalom a Preußisches Allgemeines Landrecht vonatkozó rendelkezésében tünt fel (gemeinsames Unglück), ${ }^{700}$ később ez került a magyar terminológiába is. Az 1794-es porosz törvénykönyv is ugyanúgy szabályozta ezt a helyzetet, ahogy azt ma a Ptk. is teszi. ${ }^{701}$ További kérdések is felvethetők, amelyek a mai szabályozás alapján is megválaszolatlanul maradnak, pontosabban szólva a bírói gyakorlatra várnak. Ezek közé tartozik, mely esetekben kell vagy lehet vélelmezni az egy időben történő elhalást. A fogalommal önmagában is gondok vannak, ugyanis a közös veszéllyel nem azonos az a konkrét ok, amely a halálhoz közvetlenül vezet. Hamza Gábor és Sajó András szerint helyesebb lenne a közös esemény kifejezés használata. $^{702}$ A közös esemény fogalmát is megfelelően kell értelmezni mind térbeli, mind időbeli szempontból. Aggályokat támaszthat az is, ha nem ugyanazon ok miatt haltak meg a személyek, megállapítható-e a közös esemény miatti kiesés. ${ }^{703}$

Egyetértünk az alábbi állásponttal: „Valójában azonban törvényi vélelem felállításával sem lehet elkerülni a méltánytalan és igazságtalan eredményt; nem szólva arról, hogy a törvényi vélelem megdönthetőségének elvén ugyancsak nagyon nehezen

\footnotetext{
${ }^{697}$ Nótári - Papp 2013. 205-206.

${ }^{698}$ Orosz 2014a. 20.

${ }^{699}$ Orosz 2014a. 21., Orosz 2014b. 266., Orosz 2014c. 219-220.

${ }^{700}$ Hamza - Sajó 195.

${ }^{701}$ Nótári - Papp 2004. 14.

${ }^{702}$ Hamza - Sajó 200-201.

${ }^{703}$ Hamza - Sajó 201-202.
} 
kezelhető bizonyítási eljárások indulhatnak. Emiatt a jogalkotó e helyütt nem vélelmet állított fel az öröklési sorrendet illetően, hanem kötelező szabályt alkotott a kiesésnek erre az esetkörére.",704

Megemlíthető még az is Orosz Árpád nyomán, hogy bár azok, akik az adott kiesési okra vonatkozó szabályozás hiányát felvetették, családtagok (hozzátartozók) haláláról szóltak, a Ptk. szövegében nincs ilyen tartalmú szükítő rendelkezés. Következésképpen ez a rendelkezés mindazokra is kiterjed, akik egymással nem hozzátartozói, hanem egyéb öröklési jogi kapcsolatban (pl. örökhagyó és végrendeleti, vagy szerződéses örökös) állnak. ${ }^{705}$

\subsection{Társasági jogi kapcsolódás}

A közös veszéllyel összefüggő kérdéskört példák segítségével ${ }^{706}$ érdemes áttekinteni a régi Ptk. 600. $\S-\mathrm{a}^{707}$ [a) pont], a Ptk. 7:4. § (1) bekezdése ${ }^{708}$ [b) pont, mintha nem lenne vélelem] és a közös veszélyre vonatkozó vélelem ${ }^{709}$ alapján [c) pont]. A hatályos Ptk.-ra vonatkozó szabályokat tehát célszerü akként különválasztani, milyen eredménnyel járt volna, ha nem állapítja meg a közös veszélyre vonatkozó szabályt a jogalkotó, ugyanis egyes esetekben különbség van. A példák mindegyikében szerepel egy házaspár, figyelemmel arra, hogy a közös veszélyre vonatkozó vélelem az egymás után történő öröklés kizártságáról rendelkezik, nincs ezért relevanciája az olyan helyzetnek, amikor a közös veszély megállapítását megalapozó veszélyhelyzetben érintett személyek nem örökölnének egymás után törvényes vagy végrendeleti öröklés, illetve öröklési szerződés alapján. Megjegyzendő, hogy utóbbi kettő öröklési jogcím esetén nem szükséges az örökhagyó és az örökös között bárminemű hozzátartozói ${ }^{710}$ vagy rokoni ${ }^{711}$ kapcsolat, de abból a szempontból ez irreleváns, hogy a vélelem nem tesz különbséget az egyes jogcímek között. (Természetesen amennyiben az állam

\footnotetext{
${ }^{704}$ Orosz 2014a. 20.; Orosz 2014c. 219.

705 Orosz 2014c. 220.; Orosz 2014a. 21.; Orosz 2014b. 266.

${ }^{706}$ A példák alapjául Nótári - Papp 17-22. szolgált.

${ }^{707}$ Kiesik az öröklésből a) aki az örökhagyó elött meghal.

${ }^{708}$ Kiesik az öröklésböl, aki nem éli túl az örökhagyót.

${ }^{709}$ Ptk. 7:4. § (1) bek. második fordulata

${ }^{710}$ Ptk. 8:1. § [Értelmezö rendelkezések]

(1) E törvény alkalmazásában

1. közeli hozzátartozó: a házastárs, az egyeneságbeli rokon, az örökbefogadott, a mostoha- és a nevelt gyermek, az örökbefogadó-, a mostoha- és a nevelőszülő és a testvér;

2. hozzátartozó: a közeli hozzátartozó, az élettárs, az egyeneságbeli rokon házastársa, a házastárs egyeneságbeli rokona és testvére, és a testvér házastársa.

${ }^{711}$ Ptk. 4:96. §
} 
öröklésére kerülne sor, akkor sincs ilyen családjog kapcsolat.) A házaspárok példáként szolgálnak arra is, hogy az egyes házastársak vagyona, bennük a gazdasági társasági részesedés (a vagyoni hozzájárulással kapcsolatos elszámolási igény közkereseti és betéti társaságban, üzletrész korlátolt felelősségü társaságban, valamint a részvénytársaságban tagsági jogokat megtestesítő részvény) amelyet esetenként még élő szüleiktől kaptak, a halálozások egymást követő véletlenszerüségének köszönhetően, átszállhat házastársuk családjára. Eltérő megoldások adódnak abban az esetben, ha akként vizsgáljuk ezt a helyzetet, hogy volt-e a házaspárnak a közös veszélyben érintett közös gyermeke (6.3.2. pont) vagy sem (6.3.1. pont), továbbá valamely házastársnak van-e másik, nem a házastársától született gyermeke (6.3.2.3-6.3.2.7. pontok).

A fejezet megírásánál alkalmaztuk a jogszabályok nyelvtani, valamint logikai értelmezését, amelyek segítségével a fent megállapított ismérvek kombinálása révén létrejövő összes lehetséges felmerült vázolt eset elemzése történt.

\subsubsection{A vélelem alkalmazása házastársak halála esetén}

6.3.1.1. Amennyiben egy leszármazó nélküli házaspár tagjai közlekedési balesetben halnak meg, és az egyik házastárs megállapíthatóan néhány perccel túléli a másikat.

a) A régi Ptk. alapján leszármazók hiányában ez a házastárs örököl, majd az örökössé váló házastárs teljes vagyonát (beleértve az először meghalt házastárs hagyatékát) ennek a házastársnak szülei öröklik. ${ }^{712}$ Ha a korábban elhunyt házastárs valamely gazdasági társaság tagja volt, e formának megfelelően következik be a jogutódlás a ráeső társasági vagyonban: ekkor nem sokkal később elhunyt házastársa, majd azok szülei és rokonai lesznek jogosultak a tag rokonai helyett az üzletrészre, az elszámolási igényre közkereseti/betéti társaságoknál.

b) A vélelem nélküli föszabály ugyanezt a helyzetet eredményezi, ${ }^{713}$ tekintettel arra, hogy az egyik házastárs túléli a másikat, így nem esik ki az öröklésből.

c) A vélelem már eltérő helyzetet eredményez, amennyiben az maradéktalanul megállapítható: nem fog örökölni egyik házastárs sem a másik után, így a korábban elhalt házastárs tag rokonai kapják az elhunytat korábban megillető, és

\footnotetext{
${ }^{712}$ régi Ptk. 607. § (4) bek., 608. § (1) bek.

${ }^{713}$ Ptk. 7:63. §
} 
a halál folytán átszállni képes jogosultságokat, a később elhunyt házastárs rokonai pedig csak rokonuk után örökölnek.

Közkereseti és betéti társaságok esetén ahhoz, hogy az elhunyt tag örököse beléphessen a társaságba, a társaságban maradt tagokkal meg kell egyeznie. ${ }^{714} \mathrm{Az}$ örökösök az a)-b) esetben a később elhunyt házastárs szülei lesznek, a bekövetkezett halál sorrendjéhez igazodóan. Abban az esetben, ha csak az egyik házastárs volt a társaság tagja, akkor lehetőség van az örökös beléptetésére, tekintettel arra, hogy mindenféleképp lesz társaságban maradt személy a társaságok törvényi fogalmára figyelemmel. A közös veszélyre irányadó vélelem alkalmazásával a vagyonok eredete szempontjából igazságosabb vagyonelosztás valósul meg: egyértelműen az elhunyt tag hozzátartozói kapják meg az elhalt tagot kiválása esetére megillető elszámolási igényhez való jogot.

Korlátolt felelősségü társaságok esetén az üzletrészt megszerezhetik az örökösök. A hatályos Ptk. alapján az átszállás korábbi automatizmusa bizonyos tekintetben megszakadt, amikor az örökösök nyilatkozatától teszi függővé azt, hogy az ügyvezető bejegyzi-e a tagjegyzékbe az örököst, ${ }^{715}$ akinek a személyének megállapítása a közkereseti/betéti társasághoz hasonlóan történik. Azaz eltérően alakul attól függően, alkalmazható-e a közös veszélyre vonatkozó vélelem, mert ha igen, akkor az elhunyt tag rokonainak lesz lehetőségük megszerezni az üzletrészt, ha nem, az elhalálozás véletlenszerű sorrendje jelentősebb vagyon idegen családra szállását eredményezheti.

Házastársi társaság esetén, azaz ha a gazdasági társaság tagjai egy házaspár tagjai voltak, eltérően alakul a gazdasági társaság sorsa közkereseti/betéti társaságoknál és korlátolt felelősségü társaságoknál. Az üzletrészeket a hatályos jogszabályok alapján is megszerezhetik a házaspár örökösei, tekintet nélkül azok személyére, ha kérelmezik az ügyvezetőnél tagként való bejegyzésüket. Közkereseti társaságoknál ehhez képest teljesen eltérő jogkövetkezmények állnak elő, ha a tagok egy balesetben elhaláloznak: ez a jogi tény szükségszerüen a társaság jogutód nélküli megszünéséhez vezet. Nem lesz olyan tag, aki megegyezhetne az örökösökkel, ezért a Ptk. 3:152. § alapján a házaspár halálától (a közös veszély vélelme folytán a balesettől) számított 6 hónap elteltével meg fog szünni a társaság. A betéti társaság fogalmi elemét képezi a két eltérő jogállású tag, a beltag és a kültag léte. ${ }^{716}$ Akkor szünik meg jogutód nélkül ez a társaság, ha

\footnotetext{
${ }^{714}$ Ptk. 3:149. §

${ }^{715}$ Ptk. 3:170. $\S(1)$ bek.

${ }^{716}$ Ptk. 3:154. $\S$
} 
valamennyi beltag vagy valamennyi kültag tagsági jogviszonya megszünik - ezen esetek közé tartozik a tag halála is -, és a társaság nem jelent be újabb tagot a cégbíróságnak a tagsági jogviszony megszünésétől számított hat hónapon belül, illetve ha nem alakul át e határidő alatt közkereseti társasággá, ${ }^{717}$ ahol nincsenek a tagi felelősség szempontjából megkülönböztetett tagok. E társaságokba való belépés csak jogügyleti alapon lehetséges, a Ptk. 3:149. § alapján a meghalt tag örököse a társaság többi tagjával való megegyezés alapján a társaságba tagként beléphet, ez pusztán öröklés útján nem lehetséges. Esetünkben azonban nincs olyan tag a halál miatt, aki az örökössel meg tudna egyezni és a társasági szerződést módosítani tudná, így a házaspár örökösei nem tudnak belépni, nem folytathatják a társaságot. Ebben az esetben a vélelem ugyan a hagyaték többi részének elosztásában segíteni fog, de a társaságot nem képes megmenteni.

Abban az esetben, ha a házaspáron kívül harmadik személy is a társaság tagja, ez a személy meg tud egyezni az örökösökkel a társasági szerződés módosításáról közkereseti/betéti társaságok esetén, hasonlóan ahhoz a helyzethez, amikor csak a házaspár egyik tagja a társaság tagja. Ha a házaspáron kívül csak egyetlen - a balesetnél jelen nem volt - közös gyermekük tagja a társaságnak, akkor ugyan ö örökli az elszámolási igényt, örökösként azonban nem léphet be, de lehetősége van arra, hogy más személyt léptessen be tagként, akinek - eltérően a Ptk. 3:149. §-ban foglaltaktól, figyelemmel arra, hogy ez a személy nem örökös - új tagként vagyoni hozzájárulást kell teljesítenie.

Amennyiben a kft. társasági szerződésében - akár a Gt., akár a Ptk. alapján meghatároztak olyan személyt, aki az üzletrész megváltására jogosult, ha él ezzel a lehetőségével, megválthatja az örököstől az üzletrészt, ${ }^{718}$ megnehezítve ez által új személy belépését a társaságba. Ha ez a személy, házastársi társaság esetén, éppen részese a közös veszély vélelmének alkalmazhatóságát előidéző balesetnek, a társasági szerződés e rendelkezése kiüresedik, az üzletrészt megöröklik az elhunyt tag örökösei. Tekintettel arra, ha házastársi társaságról van szó, a közös gyermekek kapják meg az üzletrészeket egyenlő arányban mindkét tag, azaz a szüleik után, ${ }^{719}$ ha csak egyetlen gyermekük örökli az üzletrészeket, egyszemélyes kft. fog létrejönni. ${ }^{720}$ Attól az időponttól, amikortól létrejön az egyszemélyes társaság, mert valamennyi üzletrészt

\footnotetext{
${ }^{717}$ Ptk. 3:158. $\S(1)$ bek.

${ }^{718}$ Ptk. 3:170. § (2) bek.

${ }^{719}$ Ptk. 7:55. $\S(1)-(2)$ bek.

${ }^{720}$ Ptk. 3:208. § (2) bek.
} 
egyetlen személy, jelen esetben a kiskorú örökös szerzi meg, az egyszemélyes társaságra vonatkozó szabályok szerint müködik tovább.

A részvénytársaságoknál az igazgatóság bejegyeztetheti a részvénykönyvbe az örökösöket, mert a részvényes csak attól az időponttól tudja gyakorolni részvényesi jogait a részvénytársasággal szemben, ${ }^{721}$ de a részvények öröklésére ipso iure sor került. Meg kell azonban jegyezni, hogy valószínüleg nincs ügyvezető, illetve igazgatóság kétszemélyes (ráadásul házastársi) társaságoknál, amely a helyzet megoldását nem feltétlen tudja biztosítani.

Elképzelhető az az eset, hogy a közös veszélyben elhunyt házaspárnak egy közös kiskorú gyermeke volt. Ez a gyermek nem válhat a szülei közkereseti társaságának tagjává, illetve a betéti társaság beltagjává a Ptk. rendelkezései szerint, mivel kiskorú gazdasági társaság korlátlanul felelős tagja nem lehet. ${ }^{722}$ Ebből a contrario az a következtetés vonható le, hogy a kiskorú lehet kültag, kft tagja, valamint részvényes.

A gazdasági társasággal kapcsolatos döntések meghozatala olyan ügynek minősül, ami nem tartozik abba a körbe, amiben egy cselekvőképtelen, vagy korlátozottan cselekvőképes kiskorú önmaga dönthet, az ilyen jognyilatkozatok semmisek, ezért szüksége van törvényes képviselőre, aki el fog járni a nevében. ${ }^{723} \mathrm{Ez}$ a törvényes képviselő a gyám lesz, ugyanis az a kiskorú, aki nem áll szülői felügyelet alatt, gyámság alá tartozik, ${ }^{724}$ és a gyám, ha a Ptk. eltérően nem rendelkezik, a gyámsága alatt álló gyermek gondozója, nevelője, vagyonának kezelője és a gyermek törvényes képviselője. ${ }^{725}$ Továbbá a gyám köteles a gyermek pénzét és értéktárgyait ha azokat a rendes vagyonkezelés szabályai szerint készen tartani nem kell - a gyámhatóságnak átadni. ${ }^{726}$

A hagyatéki eljárás során a leltár egy példányát az illetékes gyámhatóságnak is meg kell küldeni a szükséges intézkedések megtétele végett, és a gyámhatóság rendeli ki a gyámot, erről pedig a közjegyzőt értesíteni köteles. ${ }^{727} \mathrm{Ha}$ ez a leltározás során nem

\footnotetext{
${ }^{721}$ Ptk. 3:246. $\S(1)$ bek.

${ }^{722}$ Ptk. 3:90. § (1) bek. második fordulat. Ez a rendelkezés kógensnek minősül, attól való eltérés a Ptk. 3:4. §-ába beillesztett diszpozitivitási teszt alapján nem lehetséges. A kógencia és diszpozitivitás kérdéséhez lásd még Auer; Metzinger 42-56.

${ }^{723}$ Ptk. 2:14. § (1) bek.

${ }^{724}$ Ptk. 4:223. §

${ }^{725}$ Ptk. 4:224. §

${ }^{726}$ Ptk. 4:236. $\S$

${ }^{727}$ Vö. Hetv. 24. §
} 
történt meg, akkor a közjegyző keresi meg a gyámhatóságot eseti gyám kirendelése végett, mert az öröklésben érdekeltnek nincs törvényes képviselője, és kiskorú. ${ }^{728}$

6.3.1.2. Abban az esetben, ha a házaspár tagjai egyszerre haltak meg a balesetben,

a) a régi Ptk. alapján - ha egyikük sem halt meg a másik előtt - egymás után kölcsönösen örökölnek, utánuk pedig a szüleik. ${ }^{729}$ Ha ugyancsak egyik házastárs volt tag egy gazdasági társaságban, a kölcsönös öröklés miatt ezek a tagsági jogok átkerülnek a házastárs családjához.

b) Ha egyszerre halt meg a házaspár mindkét tagja, akkor egyikük sem élte túl a másikat, tehát kiestek az egymás utáni öröklésböl, aminek folytán ugyanaz a helyzet következik be, mint ami a 6.3.1.1. c) pontban került kifejtésre.

c) A vélelem alkalmazásával is ugyanerre az eredményre jutnánk, ez is volt a jogalkotó célja, amely a vagyoni eredet szempontjából igazságosabb vagyonelosztáshoz vezet.

Szintén el lehet különíteni az egyes jogi helyzeteket a társasági formák alapján.

Közkereseti és betéti társaságok esetén, ha csak az egyik házastárs volt tag, nem lesz különbség a 6.3.1.1. pontban írtakhoz képest. Ezért igaz az, hogy a társasági szerződés módosítása szükséges ahhoz, hogy egy új tag, az örökös beléphessen a társaságba. A fent leírt esetben a régi Ptk. alapján a házastársak egymás után kölcsönösen örökölni fognak, majd átkerül az elszámolási igény a nem tag családjába. Az új főszabály és a vélelem alkalmazása is a vagyonelosztás igazságosabb módjához közelít. Hasonló helyzet áll elö üzletrészek vonatkozásában is.

Házastársi társaságnál némileg differenciáltabb képet kapunk. Tekintettel arra, hogy mindketten tagok voltak, a régi Ptk. szerinti kölcsönös öröklés kevésbé okoz igazságtalanságot, mindkét tag szülei jogosultak a hagyaték tárgyát képező elszámolási igényre, a szülők viszont menyük/vejük vagyoni hozzájárulására, aminek mértéke eltérő lehet, ha az egyik házastárs eleve nagyobb részesedéssel bírt a társaságban. A főszabály és a vélelem folytán ilyen ,vagyoncserére” nem kerül sor, viszont ugyanarra az eredményre juthatunk. A társaság szükségszerüen meg fog szünni, hiszen életben maradt taggal való megegyezés szükséges tag belépéséhez, ennek hiányában az utolsó tag kiválásától, figyelemmel arra, hogy egyszerre haltak meg, a bekövetkezett haláltól számított hat hónap elteltével törölni kell a cégjegyzékből a gazdasági társaságot.

\footnotetext{
${ }^{728}$ Hetv. 49. $\S(1)$ bek. a) pont

${ }^{729}$ régi Ptk. 607. § (4) bek., 608. § (1) bek.
} 
Korlátolt felelősségü társaság vonatkozásában nem rendelkezett a Gt., és nem rendelkezik a Ptk. sem a jogutód nélküli megszünésről, ezek kölcsönös öröklésére a régi Ptk., illetve a Ptk. alkalmazásában a kölcsönös kiesés miatt a szülök általi öröklésére minden további nélkül sor kerülhet.

Ha ennek a házaspárnak van olyan közös gyermeke, aki nem esett ki az öröklésből, nem volt a baleset részese, habár az elszámolási igényhez való jogot megszerzi, a társaságba nem léphet be, meg fog szünni a közkereseti társaság. A közös gyermek megszerezheti ugyanakkor a házastársi kft-beli üzletrészeket, amennyiben nincs olyan élő személy, aki azok megváltására (akár a Gt., akár a Ptk. rendelkezései alapján) jogosult lenne.

Ha egy harmadik személy is tag adott gazdasági társaságban, ha közkereseti/betéti társaságról van szó, megegyezhet az örökösökkel a társasági szerződés módosításáról, e személyek belépéséről. Kft. esetén az örökösök megszerezhetik az üzletrészt, a Ptk. hatálya alatt akkor, ha eziránti kérelmet nyújtanak be az ügyvezetőnek. Elképzelhető, hogy éppen ez a személy lesz az üzletrész megváltására jogosult, az ö döntésétől függ, a társaság tagjaivá válhatnak-e: ha megváltja az üzletrészeket, egyszemélyes kft. fog létrejönni.

\subsubsection{A közös veszélyre vonatkozó vélelem alkalmazása házastársak és a közös veszélyben érintett közös gyermekük halála esetén}

6.3.2.1. Ha egy házaspár és közös gyermekük szintén egy balesetben elhalálozik, és a szülők megállapíthatóan elöbb halnak meg, mint a gyermekük:

a) a gyermek örököl szülei után, ${ }^{730}$ azonban leszármazók, házastárs, szülők (ők már kiestek az öröklésből korábbi haláluk miatt), szülői leszármazók hiányában (csak ő volt), törvényes örökösök a gyermek nagyszülei, illetve kiesésük esetén az ő leszármazóik. ${ }^{731}$

b) A Ptk.-beli vélelem nélküli főszabály is ehhez az eredményhez vezet. ${ }^{732}$

c) A közös veszélyre vonatkozó vélelemmel is erre a következtetésre jutunk, azaz nincs alapvető különbség a régi Ptk. és a hatályos Ptk. között ilyen esetben.

\footnotetext{
${ }^{730}$ régi Ptk. 607. § (1) bek.

${ }^{731}$ régi Ptk. 609. § (1)-(2) bek.

${ }^{732}$ Ptk. 7:55. § (1) bek., 7:64. § (1)-(2) bek.
} 
Annyiban van eltérés, hogy rögtön a nagyszülöi parentéla örököl, nem történik öröklés az elhunytak között.

Amennyiben csak az egyik szülő tagja egy közkereseti/betéti társaságnak, abban az esetben a régi Ptk. alapján először a gyermek szerzi meg a vagyoni részesedést, de az ő (és szülei) bekövetkezett halála miatt a nagyszülők és azok leszármazottai kapják meg a hagyatékot. Ez azt jelenti, hogy azok a - gyermek szemszögéből - nagyszülök is részesülni fognak a társasági vagyonból, akiknek a gyermeke (azaz a közös gyermek édesanyja/édesapja) nem is volt tag. Ha van még egy másik életben maradt tag, akkor mind a négy nagyszülőnek, ezek kiesése esetén leszármazottaiknak (nagynénik/nagybácsik) lehetőségük nyílik arra, hogy taggá váljanak, ha sikerül megállapodniuk az életben lévő taggal. Alapvetően ez a jogi helyzet a hatályos Ptk. rendelkezései alapján is társasági jogi szempontból.

Korlátolt felelősségű társaságok esetén az üzletrészek öröklése szintén hasonló módon következik be: valamely szülő üzletrészét (e tekintetben nincs különbség egymáshoz képest történt elhalálozásuk tekintetében a régi Ptk. alapján) előbb a gyermek szerzi meg, amit majd ugyancsak a nagyszülők fognak négy egyenlő részben megkapni.

A Ptk. alapján, amennyiben nem vonatkozna a közös veszélyre vélelem, ha elöször a kft tagja hal meg, őt követi házastársa, akkor a vagyoni részesedést, illetve üzletrészt kettő egyenlő részben a kis idővel őt túlélő házastársa és a gyermekük kapja meg. ${ }^{733}$ A házastárs részesedését halálát követően a gyermek kapja meg, amit végül szintén a nagyszülők kapnak meg. A vélelem alkalmazásával ugyanerre jutunk, de a jelzett keresztöröklések nélkül.

Házastársi társaság esetén a korábbiakhoz igazodóan a kkt és bt meg fog szűnni, mivel nem lesz olyan személy, aki be tudná léptetni az örökösöket vagy más új tagot. Csupán a társaság vagyonával való elszámolás valósulhat meg, ez a régi Ptk. alapján a gyermek számára állagot, a kis idővel túlélő házastárs számára haszonélvezetet biztosított, a Ptk. szerint az elöbbiekhez hasonló keresztöröklés következik be, majd végül mindkét törvénykönyv alapján a nagyszülők és ezek leszármazottai lehetnek jogosultak a társaságba történő belépésre.

Az üzletrészek tekintetében hasonló megoldásra jutunk, ha házastársi társaságról van szó: a gyermek teljes állagot, illetve annak felét kapja meg. Ezt csak az

${ }^{733}$ Ptk. 7:58. § (1) bek. 
befolyásolja, van-e az üzletrész(ek) megváltására jogosult személy, aki ha a másik házastárs, nem lesz ilyen személy, harmadik személy esetén pedig ő lesz jogosult eldönteni, megengedi-e a nagyszülöknek, leszármazottaiknak az üzletrész megszerzését.

Ha a házastársak mellett harmadik személy is a társaság tagja volt, kkt és bt esetén úgyszintén megegyezhet az örökösökkel azok belépéséröl, kft esetén pedig megszerezheti az üzletrészeket. Ez a harmadik tag is lehet üzletrész megváltására jogosult, akinek a döntésétől függ az új személyek, az örökösök belépése.

6.3.2.2. Amennyiben előbb a gyermek hal meg, és csak ezután a szülei eltérő időpontokban:

a) a meghalt gyermek után leszármazók és házastárs hiányában a szülők örökölnek fejenként egyenlő részben. Az egyik szülő halála után, (leszármazó hiányában) házastársa örökli a teljes vagyont, ennek halála után az ő szülei (és ezek leszármazói) öröklik a teljes hagyatékot. Ezzel az esetleges gazdasági társasági részesedés szintén átszállhat a - gyermek szempontjából - másik ágra.

b) Az új főszabály szerint a szülők túlélésük miatt nem esnek ki az öröklésböl, ezzel az elöbbi a) pontban vázoltak következnek be.

c) A vélelem alkalmazásával a szülők nem örökölnek egymás után, még a gyermek után sem, végül leszármazók, házastárs, szülők hiányában a gyermek nagyszülei fogják megkapni a hagyatékot. A tag részesedése vonatkozásában a tag szülei fognak örökölni.

Ha csak az egyik szülő volt egy adott gazdasági társaság tagja, a gyermek kiesésével föszabály szerint - a régi Ptk. alapján - a házastárs örököl. Amennyiben a részesedést illetően megállapítható ági vagyoni jelleg, ${ }^{734}$ abban az esetben a házastárs egyáltalán nem örökölné azt se kkt/bt, se kft esetén. Másik tag megléte esetén ez a személy gondoskodhat arról, hogy a társasági szerződést módosítsa, az örököst beléptesse, aki a fent vázolt esetben a másodikként elhalt házastárs szülei, és ezek leszármazottai lennének, tekintet nélkül arra, hogy ez a házastárs volt-e a tag vagy sem. Az ezzel elöálló igazságtalannak tünő helyzetet orvosolja a közös veszélyre vonatkozó vélelem: mindenféleképp az elhalt tag szülei és ezek leszármazottai jogosultak az elszámolási igényre, ők léphetnek be a társaságba, valamint szerezhetik meg az

${ }^{734}$ Ptk. 7:67. § 
üzletrészt. Utóbbit akkor, ha nincs megváltásra jogosult személy, vagy ez a személy nem kíván ezzel a jogával élni.

Házastársi közkereseti/betéti társaság esetén a régi Ptk. szerint vázolt igazságtalanság fennállhatott: habár mindkét nagyszülőpár gyermeke tag volt, egyrészt nem biztos, hogy a részesedésük egyenlő volt, másrészt az egyik nagyszülőpár kaphatja meg a teljes társasági vagyont. Ahogy az megfigyelhető, ebben az esetben a társaság mindenféleképp megszünik, a vagyoni helyzet megfelelő rendezése lehet csak kérdéses. A Ptk.-ban felállított vélelem egy jobb elosztást tesz lehetővé: az esetleges nagyobb mértékü részesedéssel bíró tag szüleinek keletkezik gyermekük részéhez kapcsolódó elszámolási igénye, illetve örökölhetik az üzletrészt.

Ha a házaspáron kívül más is tag volt, ugyanúgy igaz az, hogy ez a személy léptethet be újabb tagot a közkereseti, illetve betéti társaságba, ha sikerül megegyezni az örökösökkel. Korlátolt felelősségü társaságoknál az üzletrész megváltására jogosult lehet ez a harmadik személy is, továbbra is az ő döntésétől függ, megszerzik-e azt az örökösök (nagyszülök és leszármazottaik), vagy adott esetben egyszemélyes kft jön létre, ha magához váltja azokat.

Akkor, ha a szülök mellett a gyermek volt a közkereseti/betéti/korlátolt felelősségü társaság tagja, a szülőknek előbb igényük keletkezik az elszámolásra, valamint kft.-nél megöröklik az üzletrészt, az ő haláluk sorrendjében örökölnek a régi Ptk. alapján, ezáltal az egyik nagyszülőpár kapja meg a teljes társasági vagyont; felefele arányban a Ptk. szerint a közös veszélyre vonatkozó vélelem alkalmazásának segítségével. A közkereseti/betéti társaságok kiváló (elhalt) tagot megillető elszámolási igénye iránt ugyanezen személyeknek van.

6.3.2.3. Tegyük fel, hogy a házaspárnak van egy közös gyermeke, míg a férjnek előző házasságából van még egy másik gyermeke is, aki túlélte a balesetet, vagy nem is volt részese annak. A halálozás sorrendje bizonyítottan: 1. anya, 2. apa, 3. közös gyermek.

a) A régi Ptk. alapján az anya után a közös gyermek, az apa után pedig a közös és a korábbi házasságából született gyermek örököl fele-fele arányban, majd ezt a felet is a féltestvér kapja meg, miután a közös gyermek leszármazó, házastárs, szülő hiányában hal meg. ${ }^{735} \mathrm{Ha}$ az anyának pl. üzletrésze volt egy kft-ben, az ő családjához képest idegen család fogja megszerezni azt.

\footnotetext{
${ }^{735}$ régi Ptk. 608. § (2)-(3) bek.
} 
b) A Ptk.-beli főszabály alapján az előzőek némiképp változni fognak: az anya halála után a közösen lakott lakáson a férj/apa holtig tartó haszonélvezeti jogot szerez, illetve egy gyermekrésznyit kap minden más vagyontárgyból a közös gyermek mellett, ${ }^{736}$ azaz jelen esetben fele részt (akár egy üzletrész felett közös tulajdona lesz, ha rövid ideig is, az apának és a közös gyermeknek). Az apa halálával a nejéről rászállt örökrész a gyermekei között oszlik meg, az üzletrész negyede már a féltestvéré, majd a közös gyermek halála után a teljes hagyaték az övé lesz. Amennyiben egyidejüleg halnak meg, igazságosabb eredmény lenne: a féltestvér és az anya szülei öröklik a vagyont fele-fele részben.

c) A közös veszélyre vonatkozó vélelem alkalmazása ugyanazt a helyzetet eredményezi, mintha egyidejü elhalálozást vélelmeznénk: a gyermek anyai nagyszülei és a féltestvér lesznek örökösök fele-fele arányban.

Abban az esetben, ha az anya volt a közkereseti/betéti társaság egyik tagja, a gyermek fogja megszerezni az ő vagyoni részesedését, ami a halálával végül a féltestvérre fog átszállni, így kerül idegen családhoz a részesedés. Ha az életben maradt tagnak sikerül megegyeznie a féltestvérrel, az örökössel, a társaság továbbműködhet. A Ptk. alapján annyi a különbség, hogy az anya halála után a részesedés értékének felét az apa, a másik felét a közös gyermek kapja, de végül a féltestvérre száll a teljes hagyaték. Ha az apa volt a társaság tagja, az anya korábbi halála miatt a társasági részesedés öröklése vonatkozásában kiesik, a közös gyermek és a féltestvér örököl fele-fele arányban. Ekkor nem következik be az, hogy egy idegen családra szálljon a vagyon a halálozás véletlenszerű sorrendje folytán. A végső konklúzió azonos: a féltestvér lesz az örökös, vele egyezhet meg az életben maradt tag kkt/bt esetén a belépésről, illetve ő szerezheti meg az üzletrészt. Ezen a helyzeten változtat a vélelem: az anya vagyonát az ő szülei, ${ }^{737}$ az apa vagyonát a féltestvér, ${ }^{738}$ a közös gyermek vagyonát szintén a féltestvér szerzi meg. ${ }^{739}$ Ugyanez következik be az üzletrészek átszállása esetén is.

Házastársi közkereseti/betéti, továbbá korlátolt felelősségü társaság esetén is kölcsönös öröklések figyelhetök meg: az anya részét az apa haszonélvezetével terhelten a közös gyermek kapja meg a régi Ptk. alapján, ${ }^{740}$ az apa részét a két gyermeke fele-fele arányban, a gyermek részét a féltestvére kapja meg. A Ptk. szerint az anya részét az apa

\footnotetext{
${ }^{736}$ Ptk. 7:58. § (1) bek.

${ }^{737}$ Ptk. 7:63. $§(1)$ bek.

${ }^{738}$ Ptk. 7:55. § (1) bek.

${ }^{739}$ Ptk. 7:63. § (2) bek.

${ }^{740}$ régi Ptk. 615. § (1) bek.
} 
és a közös gyermek fele-fele részben kapja, az apa után szintén a gyermekei, a gyermek után féltestvére örököl a vélelem hiányában. A vélelem alkalmazásával a féltestvér az apa, az anyai nagyszülők pedig az anya részesedésére tarthat igényt.

Családi társaság esetén (ha a közös gyermek is tag volt) az öröklési sorrendek a két törvénykönyv vonatkozásában azonosak lesznek, továbbá a vélelem joghatása is ugyanaz lesz, mind közkereseti/betéti, mind korlátolt felelősségü társaság esetén. Ha a féltestvér is tag, akkor a vélelem hiánya nélkül egyszemélyes kft jöhet létre, illetve egy új tagot kell keresnie, tekintettel arra, hogy jogelőd jogán csak ő léphetne be a társaságba, ha már nem lenne az. A családhoz képest idegen személy tagsága esete nem változtat alapvetően ezen a helyzeten, ha fennáll a vélelem, ha nem: az örökösökkel neki kell megegyeznie a társaság fennmaradása érdekében kkt/bt esetén, vagy ha ő jogosult üzletrész megváltására a korlátolt felelősségü társaságnál, erről dönthet.

6.3.2.4. Ha a halálozási sorrend eltérően alakul, az anya után a gyermek, majd az apa hal meg:

a) az anya után a közös gyermek örököl, majd a közös gyermek után az apa, aki után a külön gyermek örököl.

b) Ha ebben a sorrendben, tehát nem egyszerre haltak meg, akkor a láncolat majdnem megegyezik az előbbi 6.3.2.4. a) pontban írtakkal, az eredmény ugyanaz lesz.

c) A vélelem alkalmazása az anya szüleinek és a féltestvérnek az öröklését vonja maga után.

Két eltérő jogi megoldása lehet ennek a problémának a vázoltaknak megfelelően.

Amennyiben az apa volt tag, a féltestvéren túlmenően más személy öröklése nem bírhat relevanciával, akkor is, ha alkalmazzuk a vélelmet, akkor is, ha nem. Ha az anya, végső soron a vélelem nélkül a féltestvér lesz jogosult a közkereseti/betéti társaságba történő belépésre, üzletrész megszerzésére, a vélelem alkalmazásával az anya szülei szerezhetik meg azokat.

Házastársi társaság esetén (mindhárom társasági formánál) a kérdésre hasonló választ kaphatunk, annyiban, hogy a vélelem alkalmazásával egyfajta öröklési igazságosság valósulhat meg. A társasági részesedéshez kapcsolódó esetleges ági jelleg is ezt mozdíthatja elö. 
Ha harmadik személy is a társaság tagja volt a házastársak mellett szintén mindhárom gazdasági társaságnál, akkor is igaz lesz a hasonló helyzetekre írtak, neki lesz joga új tagot beléptetnie, valamint az üzletrész megváltásáról dönteni. Ugyanúgy elenyészik ez a jogosultság, ha valamely szülö lett volna arra jogosult. Ez a harmadik személy ugyanúgy lehetett a közös gyermek is, sőt, a féltestvér, amely helyzetre szintén a korábbiak lesznek igazak.

6.3.2.5. Ha elöször az apa hal meg, öt követi az anya, majd a közös gyermek:

a) az apa halála esetén a gyermekek örökölnek fele-fele arányban, az anya halála után a közös gyermek örököl, aki után szintén - miután a szülei kiestek az öröklésből, leszármazók és házastárs hiányában a féltestvér.

b) Egyszerre elhalás vélelmezése esetén jutnánk csak eltérő megoldásra a hatályos Ptk. alapján, különben az előző pontok lesznek igazak.

c) A vélelem alkalmazása esetén a féltestvér és a közös gyermek anyai nagyszüleire száll a hagyaték.

Ha az egyik házastárs tag egy gazdasági társaságban, és ez a személy az apa: kkt és bt esetén a régi Ptk. alapján a gyermekeknek nyílik joga arra, hogy örökösként belépjenek apjuk helyére azzal, hogy az anya haszonélvezeti jogával meg van terhelve az egész hagyaték. A Ptk. egyik jelentős módosítása a házastárs törvényes örökléséhez kapcsolódik: az örökhagyóval közösen lakott lakáson és a hozzá tartozó berendezési és felszerelési tárgyakon holtig tartó haszonélvezetet kap a túlélő házastárs, míg a hagyaték többi részéből egy gyermekrésznyit. ${ }^{741}$ Erre figyelemmel örökli meg az elszámolás iránti igény harmadát az anya, másik harmadot a közös gyermek, a harmadik harmadot pedig a féltestvér. Az anya halála miatt a közös gyermek megkapja az ő harmadát, majd ezt a kétharmadot ennek elhunyta folytán megkapja az őt követő féltestvér, aki végül az apa teljes vagyoni hányadával a bennmaradt taggal való sikeres megegyezés esetén a társaság tagjává válhat. A vagyoni részesedések aránya hasonlóan alakul az üzletrészek vonatkozásában is.

$\mathrm{Az}$ anya tagsága esetén közkereseti és betéti társaság vonatkozásában elszámolási igénye az apának - korábbi kiesése miatt - nem keletkezik, illetve az üzletrészt nem örökölheti, az rögtön a közös gyermekükre száll. Figyelemmel ennek a

${ }^{741}$ Ptk. 7:58. § (1) bek. 
gyermeknek a közös veszély miatt bekövetkezett halálára mindkét törvénykönyv alapján a féltestvér szerzi meg ezeket a jogokat.

A közös veszély esetére felállított vélelem öröklési igazságossága az anya közkereseti/betéti társasági tagsági jogai, továbbá üzletrésze esetén érhetők tetten: nem a féltestvér örökli meg a kft-beli üzletrészt (ha nincs megváltásra jogosult személy, vagy az arra jogosult nem él ezzel a jogával), illetve nem léphet be a közkereseti/betéti társaságba, hanem az anya szülei jogosultak minderre, mindamellett, hogy a törvényi feltételek esetén akár ági vagyonnak is minősíthető. (A leszármazó ugyanis kiesett, nem örökölhet.)

Házastársi társaságnál, mind közkereseti/betéti társaság, mind korlátolt felelősségü társaság esetén a régi Ptk. szerint keresztöröklések figyelhetők meg: az apa részét az anya haszonélvezeti jogával terhelten a két gyermek örökli, az anya részét a közös gyermek, majd a gyermek részét a féltestvér kapja meg. Igazságosabb megoldást csak a hatályos Ptk. szerinti vélelem alkalmazásával kaphatunk, amellyel az anya szülei lányuk után részesülhetnek a társasági vagyonból.

Ha a házastársakon kívül más is a társaság tagja volt, akkor ezzel a harmadik személlyel egyezhet meg az örökös (csak a féltestvér a régi Ptk. alapján, az anyai szülök a vélelem alkalmazásával) a közkereseti, valamint betéti társaságba történő belépésről, illetve ő szerezheti meg az üzletrészt (kft-k esetén). Ha a közös gyermek volt ez a személy, akkor sem változik az öröklésre jogosultak köre az egyes törvénykönyvek alapján, a pontos hányadokat minden személy után külön-külön kell megállapítani, ahogy nem változik akkor sem, ha rajtuk kívül még a féltestvér is tag volt a társaságban.

6.3.2.6. Ha megváltozik a halálozás bizonyítható sorrendje: 1. apa, 2. közös gyermek, 3 . anya.

a) Az apa után szintén a gyermekei örökölnek, a közös gyermek után az anya örököl, az anya után pedig az ö szülei, ezáltal a két család között megoszlik a vagyon.

b) A vélelem nélküli főszabállyal szintén ehhez az eredményhez jutunk.

c) A vélelem alkalmazhatósága esetén eredményét tekintve szintén az a) pontban írtak valósulnak meg.

E sorrend esetén a korábbiakhoz képest egyik törvénykönyv megoldása esetén sincs eltérés. 
Ha csak az egyik házastárs volt tag egy kkt/bt-ben, e tagnak a személyétől függ a társasági részesedés sorsa: a férj tagsága esetén a régi Ptk. rendszerében a gyermekek örökölték az állagot (az elszámolási igényt) az anya haszonélvezeti jogával, a gyermekek léphettek volna be a társaságba, ha megegyeznek apjuk társával, illetve kft esetén ők szerezhették volna meg az üzletrészt (ha megváltásra jogosult személy nincs, vagy nem kíván élni ezzel a jogával). A közös gyermek halálával az anya örökli az apáról ráeső részt (a társasági tagságból eredő jogok felét), amit az ő halálával (leszármazó és házastárs hiányában) a közös gyermek anyai nagyszülei szereznek meg.

Az édesanya tagsága esetén a társasági tagságból eredő örökléshez füződő jogok (az elszámolási igény/belépés a jogelőd jogán a közkereseti/betéti társaságba - az üzletrész öröklése/annak megváltása esetén a megváltási érték a korlátolt felelősségü társaságoknál) csupán az ő szüleit, illetve azok leszármazottait illetik meg, törvényes öröklési kapcsolat hiányában a féltestvér nem örökölhet utána.

Házastársi társaság esetén az apa részesedését gyermekei kapják meg, ennek a közös gyermeket illető felét a gyermek halálával a féltestvér szerzi meg, így a társaság apára eső elszámolási igényére teljes mértékben a féltestvér lesz jogosult, míg az anyára eső részesedést az ő szülei kapják meg, amennyiben közkereseti/betéti társaságról van szó. Erre az esetre is igaz lesz az, hogy a közkereseti/betéti társaság jogutód nélkül meg fog szünni, mivel nem maradt életben lévő társasági tag. A kft-beli üzletrészt szintén ezek a személyek szerezhetik meg, hacsak nincs olyan személy, aki megváltásra jogosult lenne. A Gt. alapján csak a többi tag, illetve társaság jogosult erre; a Ptk. hasonló elöírásokat nem tartalmaz, a 3:170. § (2) bekezdése társasági szerződés által erre feljogosított személyekről ír. Ugyanakkor továbbra is célszerünek tartjuk azt, ha a társaság, illetve a tagok körére korlátozzuk a megváltásra jogosult személyeket.

Családi gazdasági társaság esetén, bármely tárgyalt társasági formánál, ha az elhalt gyermek is tag volt, hasonlóan alakul a társasági vagyoni részesedések öröklése: az apa után a gyermekek, a gyermek után anyja, az anya után a nagyszülök örökölnek. A vagyoni arányok attól függnek, mekkora részesedéssel bírtak a gazdasági társaságban a család tagjai. Amennyiben a bármely társasági forma tagja a féltestvér is, az apa elszámolási igényének, illetve üzletrésze, részvénye fele iránt keletkezik igénye, míg a közös gyermek és mostohaanyja részesedését utóbbinak szülei kapják meg. Ekkor a féltestvér állapodhat meg a nagyszülőkkel a társaságba történő beléptetésről. 
6.3.2.7. Amennyiben elöször a közös gyermek, majd az apa, és az anya hal meg a balesetben:

a) leszármazók és házastárs hiányában az apa és az anya örököl egyenlő arányban, az apa vagyonát megkapja a külön gyermek, az anya után pedig az anyai nagyszülök, illetve azok leszármazottjai örökölnek.

b) A Ptk. szabályrendszere alapján az apa és az anya örököl egyenlő arányban, de az apa halálát követően az anya, mint túlélő házastárs és a féltestvér egyenlő arányban örököl, majd az anyai nagyszülők szerzik meg az anya hagyatékát.

c) A közös veszélyben elhalás vélelme alapján is erre az eredményre jutunk.

Ha csak az egyik szülő volt a társaság tagja, a vagyon háramlása úgyszintén attól függ, ki volt ez a személy: az apa, akinek az előző házasságából van egy másik gyermeke, vagy az anya, akinek csak az apával közös gyermeke született. A közös gyermek ebben az esetben korábbi kiesése miatt nem hozható összefüggésbe társasági jogi jogutódlással. Ha az apa volt tag, akkor a társasági vagyoni részesedést csak a féltestvér szerzi meg a régi Ptk. alapján, ahhoz az anyai nagyszülöknek nem lesz közük, az ő joga lesz a közkereseti/betéti társaságba történő belépés, illetve az üzletrész megszerzése. A hatályos Ptk.-hoz képest ez annyiban mutat eltérést, hogy a féltestvér mellet az anya is örököl állagot, ezt a felet megkapják a nagyszülők, ezt az igazságtalanságot - olyanok öröklik a vagyont, akik az örökhagyónak nem is rokonai a közös veszélyben elhunytak utáni örökléséről szóló vélelem orvosolja: csak a féltestvér követelheti az elszámolási igényt, illetve az üzletrészt. Az anya tagsága esetén akár figyelembe vesszük a közös veszélyre vonatkozó Ptk.-beli vélelmet, akár nem, a nagyszülők fogják megszerezni a részesedést.

Házastársi társaság esetén bármely társasági formánál a közös gyermek újfent nem örökölhet. Az apa korábbi halála miatt a Ptk. alapján az anya és a féltestvér örököl fele-fele arányban, az anya részét szintén a közös gyermek anyai nagyszülei fogják megkapni, így ha egyenlő arányú volt a vagyoni részesedések a gazdasági társaságban, akkor ebből a szempontból ugyanakkora vagyon fog háramlani az örökösökre, egyforma lesz az elszámolási igény, valamint az üzletrészek nagysága is.

Családi társaság esetén (bármely társasági formánál) a gyermek részét leszármazó és házastárs hiányában a szülök fogják megkapni, ezután az öröklés az előbbiek szerint valósul meg, a különbség ilyen jellegü társaságoknál annyi, hogy az örökrészek a közös gyermek részesedésével növekedve szállnak át. Ha nincs más személy a közkereseti/betéti társaságban (házastársi és ilyen családi társaságnál), akkor 
ezek a társaságok szükségszerüen meg fognak szünni jogutód nélkül, akkor van lehetőség a megmentésükre, ha van hozzájuk képest harmadik személy. Ilyen személy a korábbiakhoz hasonlóan a féltestvér is lehet, ő egyezhet meg az anyai nagyszülőkkel a beléptetésről. Korlátolt felelősségü társaságok esetében, akkor pedig különösen, ha nincs megváltásra jogosult személy, vagy nem él ezzel a jogával, nem következik be jogutód nélküli megszünés, az anyai nagyszülők és a féltestvér lesz a társaság tagja.

A féltestvér is lehet a közkereseti/betéti társaság tagja: úgyszintén neki kell gondoskodnia új tagok beléptetéséröl, ha azt szeretné, hogy a társaság továbbra is müködhessen. Ezek a személyek az örökösök lehetnek, a féltestvéren kívül az anyai nagyszülök léphetnek be elődjük jogán, de ha velük nem sikerül megegyeznie, akkor más személyt is beléptethet a törvényi határidő betartásával. Ekkor megfelelően el kell számolni az anyai nagyszülőkkel, és a belépő új tagoknak vagyoni hozzájárulást kell teljesíteni.

Ugyanilyen konklúziókkal jár az a helyzet is, ha a közös gyermek után az anya hal meg, majd öt követi az apa.

\section{4. Összegzés}

A közös veszélyben elhunytak esetére felállított vélelem a hasonló szerencsétlenségekben elhunyt személyek utáni öröklést megkönnyíti, de csak akkor, ha a törvényi szabályozást megfelelően értelmezik a jogalkalmazók, szem előtt tartva annak célját. Ez a cél pedig a közös veszélyben elhunytak utáni öröklés lehető legigazságosabb rendezése, valamint az egymásba fonódó hagyatéki eljárások nehézségeinek elhárítása és a jogutódlás megállapításának meggyorsítása ${ }^{74}$ volt. A lehető legigazságosabb rendezés azt jelenti, hogy a vagyon eredete szempontjából annak a családnak kell visszajuttatni a hagyatékot, illetve annak meghatározott elemeit, amelyiktől az származott (lásd erre példaként az ági öröklési szabályokat), tehát azt, hogy ne idegenek kapják meg a családi vagyont (feltéve, hogy az öröklés nem végintézkedés útján alapján történt). Az ilyen megoldással tehát elkerülhető az olyan igazságtalannak minősíthető eredmény, ami szerint a halálesetek véletlenszerü, gyors egymás utáni, nehezen megállapítható sorrendben történő bekövetkezésétől függően

${ }^{742}$ Pusztahelyi 15. 
szintén rövid idö alatt kerüljön az örökhagyó vagyona az öt éppen csak túlélö örökösének családjához. ${ }^{743}$

A jogirodalomban megjelent egyes álláspontok arról tanúskodnak, hogy a törvénybeli megfogalmazás nyomán maradnak olyan értelmezési kérdések, amelyeknek a megválaszolása a bírói gyakorlatra hárul. A nemzetközi példák jó iránytünek minősültek abból a szempontból, hogy megmutassák, a helyzet kezelésére nincsen egyedüli helyes megoldás, ezeknek kialakulásában hatása lehet a megelőző történeti példáknak is.

A közös veszélyben elhunytak egymás utáni öröklésére vonatkozó vélelem társasági jogi szempontból releváns megnyilvánulása kapcsán elmondható: nem minden esetben képes orvosolni a kialakuló - egyelöre hipotetikus - helyzeteket, mert azokat nagymértékben befolyásolják a társasági jog Polgári Törvénykönyvön belüli, de még jobban a kódexen kívüli szabályai.

${ }^{743}$ Fábián 2015. 15. 


\section{Speciális társulások öröklési jogi vonatkozásai}

\subsection{Bevezetés}

Jelen részben bizonyos speciális társulások öröklési jogi vonatkozásaira térek ki, amelyek meghatározásánál az alábbi ismérveket vettem alapul:

- organizációs elemeket felmutató megállapodáson alapuló személy-, illetve tőkeegyesülések,

- amelyek jellemzően profitorientáltak, ${ }^{744}$ (azzal, hogy az egyszemélyes kft-k, illetve rt-k nonprofit formában is müködhetnek),

- nem tartoznak a civil szférához,

- tagjai általában természetes személyek, illetve jogi személyek lehetnek,

- a Ptk.-ban szabályozott gazdasági társaságokhoz viszonyítva különleges ismérvvel bírnak.

Ezen ismérvek alapján csoportosíthatók a társulások jogalanyiság, az általuk végzett/végezhető tevékenység, illetve cél szerint; továbbá taglétszám, valamint vagyon szempontjából. A csoportosításnak megfelelően a felvázolt kategóriákon belül a kiválasztott egyes speciális társulások, azaz a polgári jogi társaság, a koncessziós társaság, a vízgazdálkodási és az erdőgazdálkodási társulatok, az egyszemélyes korlátolt felelősségü társaság és részvénytársaság, az egyéni cégek, végül az állami részvétellel müködő gazdasági társaságok vonatkozásában a rájuk jellemző öröklési jogi vetületet, a jogutódlás lehetőségét vagy éppen annak kizártságát vázolom fel. E társulások közül néhány formációnak nincs szorosabb kapcsolata a társasági joggal, mindegyikre igaz azonban a társulati, szerződéses jelleg és/vagy a felvázolt ismérvek.

\subsection{A speciális társulások osztályozása}

\subsubsection{Jogalanyiság szerint}

A jogalanyiságot tekintve a speciális társulások közül a polgári jogi társaság ${ }^{745}$ nem bír jogalanyisággal, tehát csupán egy jogalanyiság nélküli szerződéses kapcsolat, a többi felsorolt formáció a rájuk vonatkozó szabályok alapján jogi személynek minősül.

\footnotetext{
${ }^{744}$ Fézer et al. 2012. 205.

${ }^{745}$ A polgári jogi társasághoz lásd még Ujváriné 23-42.
} 
A jogi személyiségü társaságok egyben cégek is, a cégnyilvántartásba vétellel keletkeznek, és az abból való törléssel szünnek meg, ilyenre polgári jogi társaságnál nem kerül sor a társaság jogképességének hiánya miatt. A polgári jogi társasági szerződés Ptk.-beli szabályozásánál erős személyegyesítő jelleg mutatkozik az általános rendelkezéseken túl abban is, amikor bármely szerződő fél halála esetére a szerződés megszünését írja elő a törvény ettől eltérést engedő szabályként: ${ }^{746}$ az életben maradt tagok mind a szerződő fél örökösével, mind nélküle folytathatják a társaságot, utóbbira pedig nyilvánvalóan csak akkor kerül sor, ha az örökhagyó tag nem bírt olyan személyi kvalitással, amelynek hiánya a társaság további fennmaradásának gátját szabhatná. (Megjegyzendő, hogy a polgári jogi társasági szerződésben kiköthetik a társaság megszünését valamely tag halálának esetére, de ezt később is megtehetik egyhangú módosítással.) Bármelyik következik be, a korábbi polgári jogi társasághoz képest új társaság jön létre (ellentétben a többi speciális társasággal), az előző szerződéshez képest nováció lesz.

E társaságok jogi személyiségének megítélése során a magyar álláspont hasonlít a külföldi szabályozáshoz: az osztrák irodalomban szintén felvetődött kereskedelmi nyilvántartásba történő regisztrálásuk, ezzel azonban pont a magyar jogban is tapasztalható rugalmasság veszhetne el, mert ehhez a regisztrációhoz megfelelő tartalmi és alaki követelmények teljesítése válna szükségessé. ${ }^{747}$ Ha változna is ebbe az irányba a szabályozás, a tag jogutódlása esetére irányadó szabályokon nem szükséges változtatni, az már most is hasonlít a közkereseti társaságokhoz, illetve betéti társaságokhoz, amelyek a Ptk. hatályba lépése óta jogi személynek minősülnek, ugyanakkor nem rendelkeznek maradéktalanul a jogi személyek minden ismertetőjegyével. ${ }^{748} \mathrm{~A}$ hasonlóság azonban relatív: valamely tag halála fő szabály szerint nem vezet automatikusan a kkt. és a bt. megszünéséhez, míg a polgári jogi társaság esetében igen, de mindegyik formációnál a társaságba be nem lépett örökössel ugyanúgy el kell számolni, és a hagyatéki tartozásokért való felelősség alapján fognak helytállni a társaságok tartozásaiért.

\footnotetext{
${ }^{746}$ Ptk. 6:511. $\S$

${ }^{747}$ Szikora 2004

${ }^{748}$ Papp 2014b. 150-151.
} 


\subsubsection{Tevékenység, cél alapján}

A társulások által végezhető/végzendő tevékenység vonatkozásában is elkülöníthetőek egymástól az egyes típusok: a koncessziós társaságot ${ }^{749}$ a koncessziós eljárásban eredményesen szereplő ajánlattevőnek kell megalapítania, amely a koncessziós tevékenység végzésére, illetve az állam, helyi önkormányzat kizárólagos tulajdonába tartozó vagyontárgyak létrehozására, valamint ezek müködtetésére lesz jogosult. ${ }^{750}$ A koncesszió keretében átengedhető tevékenységek, illetve tulajdont képező tárgyak körét az Nvt. határozza meg. ${ }^{751}$ A koncesszió-köteles tevékenységen kívül kizárólag azzal szervesen összefüggő — az ágazati törvényben, illetőleg az önkormányzat döntésében meghatározott — tevékenységek gyakorlására jogosult. A koncesszió elnyeréséhez támasztott követelményeknek a koncessziós társaság müködése alatt is meg kell valósulnia. ${ }^{752}$ A koncessziós társaságokra ezek miatt különleges szabályok vonatkoznak, ami azonban nem jelenti azt, hogy ne lennének irányadóak rájuk a gazdasági társaságokra vonatkozó Ptk.-beli, valamint a cégeljárási szabályok. ${ }^{753}$ A koncessziós társaságokban valamely természetes személy tag halála esetén az általános társasági jogi szabályokhoz képest eltérő szabályok fognak érvényesülni. A szerencsejáték-, valamint a bányászati koncesszióra vonatkozó jogszabály szerint ${ }^{754}$ a koncessziós szerződést aláíró személynek, aki a pályázatot nyerte, olyan társaságot kell alapítania, amelyben a megalakuláskor és a tevékenység során a részvények, üzletrészek, szavazatok többségével rendelkeznie kell. Ennek a személynek a halálával ez a kritérium nem teljesül többé: a jogutódok, ha be is következhetne a társasági formának megfelelő jogutódlás, nem minősülnek a szerződést aláíró személynek. Véleményem szerint a társaságot végelszámolás lefolytatásával meg kell szüntetni, egyúttal a koncesszióköteles tevékenység végzésére újabb pályázatot kell kiírni.

Érdemes megjegyezni, hogy speciális és részletes szabályok érvényesülnek a dohány-kiskereskedelmi koncessziónál, ${ }^{755}$ de az csak egyéni vállalkozó kereskedőnél lesz igaz, az ilyen szereplők gazdasági életben elfoglalt szerepüknél fogva érdemes

\footnotetext{
749 A koncessziós társaság vonatkozásában bővebben lásd Papp 2006. 82-92., Miskolczi Bodnár 2003. 193-221.

${ }^{750}$ 1991. évi XVI. törvény 20. § (1) bek., 23. § (1) bek., Kovács I. 17.

${ }^{751}$ Nvt. 12. § (1)-(2) bek.

${ }^{752}$ Vö. Bányatv. 13. §, Sztv. 6. § (1) bek., Papp 2015. 301-302., Miskolczi Bodnár 2016. 135-136.

${ }^{753}$ Barta - Kovács 124.

${ }^{754}$ Sztv. 6. § (1) bek.; Bányatv. 13. § (1) bek.

755 2012. évi CXXXIV. tv. 13. § (9) bek.
} 
kitérni a szabályozásra akkor is, ha nem kerül alkalmazásra. Ha a dohánytermékkiskereskedelmi tevékenységet egyéni vállalkozó folytatja, akkor annak örököse, erre irányuló igénye esetén - feltéve, hogy a jogszabályban írt egyéb feltételeknek megfelel és még ő maga is egyéni vállalkozói tevékenységet folytat, vagy dohánykiskereskedelemre irányuló kérelmét a vámhatósághoz benyújtotta - a koncessziós szerződésből eredő jogok gyakorlására és kötelezettségek teljesítésére jogosulttá, illetve kötelezetté válik. Azaz a feltételek teljesülésével a koncessziós szerződéses pozícióban következik be változás. Azt a tényt, hogy a kérelmező a dohány-kiskereskedelmi tevékenységet egyéni vállalkozói formában végző örökhagyó örököse, a hagyatéki eljárás befejezéséig közokiratba foglalt nyilatkozattal kell igazolni. Álláspontom szerint helyesebb lett volna, miután a tevékenység monopolisztikus jellege megkívánja, hogy ne kelljen megvárni adott esetben egy hosszadalmas hagyatéki eljárás befejezését hagyatékátadó végzéssel, sőt ha öröklési perre kerül sor, annak jogerős befejezését, elegendő lenne, ha a Hetv. 102. § szerinti öröklési bizonyítvány kiállíttatását követelhetné meg a törvény, ami helyesebb lenne. Ezzel ugyanis nem az örökös állítaná magáról, hogy valóban örökös, hanem egy töle független hatósági személy. Több örökös esetén további feltételt támaszt a törvény, miszerint az örökösök a jogok gyakorlásáról és a kötelezettségek teljesítéséről közokiratba foglalt megállapodást kössenek, és az állam felé a kötelezettségek teljesítésére szintén közokiratba foglalt nyilatkozattal egyetemleges felelősséget vállaljanak. Az örökösök koncesszióköteles tevékenység folytatására vonatkozó igényüket az örökhagyó egyéni vállalkozó halálát követő 30 napon belül be kell jelenteni a vámhatósághoz, valamint a nemzeti fejlesztési miniszternek, illetve a miniszter által megbízott és a nevében eljáró természetes személynek. Ebben az esetben a koncessziós szerződés hatálya fennmarad azzal, hogy ha az örökhagyó halálától számított egy éven belül a hagyaték átszállását igazoló jogerős közokiratot (így az lehet a teljes hatályú hagyatékátadó végzés, valamint ha befejeződik, az öröklési perben meghozott jogerős bírói ítélet) az örökös nem nyújtja be, vagy e közokiratból a kérelmező öröklési jogosultsága nem derül ki, (a megfogalmazásba bele lehet érteni a közjegyző által kiállított öröklési bizonyítványt is) akkor a koncessziós szerződés hatálya megszünik. Ha az örökös kérelme az említetteknek megfelel, akkor a vámhatóság az örökhagyó részére kibocsátott vámhatósági engedélyt módosítja, feljogosítva ezzel a kérelmező örököst a dohánytermék-kiskereskedelmi jogosultság további gyakorlására; ellenkező esetben a vámhatóság a vámhatósági engedélyt visszavonja. E visszavonás esetén újra kell 
kezdeni a koncessziós eljárást, amely keretében az egyéni vállalkozó kereskedő halála folytán megüresedett helyére másik ajánlattevő kerül.

Kiegészítésként megemlíthető a közbeszerzési eljárás nyertesének projekttársaság alapítására és müködtetésére vonatkozó kötelezettsége, ${ }^{756}$ ugyanis főszabály szerint a közbeszerzési eljárás nyertese teljesítheti a szerződést, és a közbeszerzési szabályok alapján az állapítható meg, hogy a projekttársaságban részt vevők személyében csak korlátozott esetekben következhet be jogutódlás, amibe az öröklés nem illeszthető bele. ${ }^{757}$ Megjegyzendő, miután csak természetes személy halála esetén beszélhetünk öröklésről és az, hogy természetes személy nyerjen meg egy közbeszerzési pályázatot, nagyon ritka eset.

Az erdőbirtokossági társulat az adott területen erdő besorolású művelési ágban nyilvántartott földrészletek tulajdonosai által az erdőgazdálkodási tevékenység hatékonyságának növelése érdekében létrehozott jogi személy, ${ }^{758}$ így a tevékenység ${ }^{759}$ is csak erre, illetve az ezzel összefüggő feladatok ellátására korlátozódhat. ${ }^{760} \mathrm{~A}$ társulatok tagjai ezen a területen erdőtulajdonnal rendelkező személyek; a lényeg az ingatlan tulajdona, aki a tulajdonos, az a tag. Amennyiben a tag elhalálozik, azok a személyek lesznek a társulat tagjai, akik az örökhagyó után az ingatlant megszerzik öröklés útján. Az örökösök válnak taggá, átszáll a társulati érdekeltség. Ha eltérően nem egyezik meg az örökös és a társulat, álláspontom szerint analóg módon a társulati érdekeltség átruházására vonatkozó szabállyal, ${ }^{761}$ a névjegyzékbe való felvétellel jön létre a tagság az örökhagyó halálának időpontjával. ${ }^{762}$ Az analógia alapját az adja, hogy a társulati érdekeltség átruházása és átszállása esetén is a szerző fél szerzi meg a tagságot; az örökös válik az erdő tulajdonosává, és csak erdőtulajdonnal rendelkező személy válhat taggá. Az átszállás fogalom a Gt.-beli korlátolt felelősségű társaságoknál használt kifejezéshez hasonlóan automatikus jellegü jogutódlást sugall. Mindezekre tekintettel ,a társulati érdekeltség szorosan kapcsolódik az erdőterület tulajdonjogához, ezért azt átruházni, örökölni csak az erdő tulajdonjogával együtt lehet."763 A társulati

\footnotetext{
756 2015. évi CXLIII. törvény 35. § (9) bek.

757 2015. évi CXLIII. törvény 138-140. §, különösen 140. § (5) bek.

${ }^{758}$ Ebtv. 25. § (1) bek.

$759 \mathrm{Az}$ erdőgazdálkodási tevékenységekre lásd az Ebtv. 28. § (4) bekezdését, ide tartozik az erdei haszonvételek gyakorlása is, erre lásd 2009. évi XXXVII. tv. 68. §

${ }^{760}$ Ebtv. 28. § (3) bek., Bobvos - Hegyes 146., Fézer et al. 2014. 201-206., Harsányi 2003. 321-348.

${ }^{761}$ Ebtv. 26. § (3) bek.

762 Ezzel egyező álláspont: Barta - Kovács 191.; Az erdőbirtokossági társulat megalakulása, In: Céghírnök 1994/10. 5.

${ }^{763}$ Csák 298.; Ebtv. 3. § (3) bek.
} 
érdekeltség átszállásával pedig a társulati tagság is átszáll a szerző félre. ${ }^{764} \mathrm{Az}$ átszállást halál esetén a hagyatékátadó végzés (öröklési perben az ítélet) jogeröre emelkedése bizonyítja, aminek kézhezvételét követően a társulat tagjairól vezetett társulati névjegyzéket az adatok változásához igazodóan haladéktalanul módosítani kell.

Lehetőség van arra, hogy a gazdasági társaságokhoz hasonlóan az erdőbirtokossági társulat is megkezdje müködését a cégbírósági bejegyzés előtt, amire az előtársaság szabályait kell alkalmazni. ${ }^{765}$ Ha még ezen - ma már egyre rövidebb periódus alatt hal meg a tag, amennyiben bejegyezték a társulatot, úgy az előzőeknek megfelelően az erdőt öröklő jogutódok válnak taggá, ha nem került sor a bejegyzésre, az alapítók együttes jognyilatkozatának minősül az előtársaság által tett jognyilatkozat, ${ }^{766}$ ami végső soron az örökhagyó tartozásaként megjelölt hagyatéki teher lesz. ${ }^{767}$ Mindezek a szabályok nem akadályozzák azt, hogy a régi Ptk. alapján az erdőn fennálló özvegyi haszonélvezeti jogot az özvegy gyakorolni tudja, semmilyen korlátozást vagy kizárást nem találhatunk. ${ }^{768}$

A Vgt.-ben meghatározott közfeladatok vízgazdálkodási társulatok ${ }^{769}$ útján láthatók el, ezek a társulatok is csak ezeket a feladatokat láthatják el, (ahogy az erdőbirtokossági társulatok a saját nemükben) más tevékenységet nem. ${ }^{770} \mathrm{~A}$ vízgazdálkodási társulatok az ellátott közfeladattól függően vízitársulat vagy víziközmü társulat lehetnek. A vízitársulat a társulati müveken területi vízrendezési, vízkárelhárítási és mezőgazdasági vízhasznosítási feladatokat lát el, a társulati műveket fenntartja, üzemelteti és fejleszti, ${ }^{771}$ a víziközmü társulat ehhez képest többek között közműves vízellátást, szennyvízelvezetést és -tisztítást végezhet. Mindkét társulat a maga feladatának ellátásában az adott területen kizárólagossággal bír. ${ }^{772} \mathrm{Az}$ erdőgazdálkodási társulatokhoz hasonlóan e társulatok tagjai is az adott müködési területen ingatlannal rendelkező személyek lehetnek. A tevékenység kötelezően ellátandó jellege és a törvény ereje miatt a tagok automatikusan válnak a vízgazdálkodási társulat tagjává, még akkor is, ha a társulat létrehozásában nem vettek részt, illetve ahhoz személyesen tagként nem jelentkeztek. Emiatt a kényszertagsági

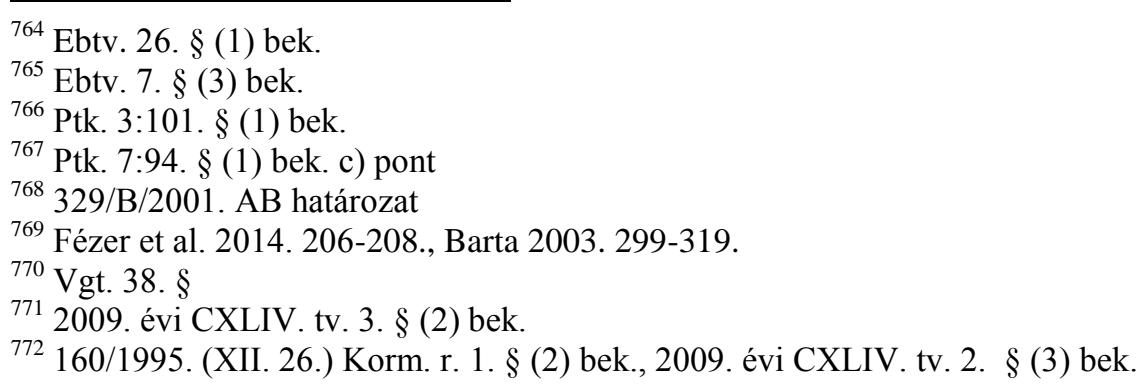


jelleg $^{773}$ a jogutódokat is terhelni fogja: aki az öröklésre vonatkozó általános szabályok szerint örökli az ingatlant, azaz akit tulajdonosként bejegyeznek az ingatlannyilvántartásba, az egyúttal a vízgazdálkodási társulat tagjává is válik. Az erdőbirtokossági társulattal együtt e kettő formációban a tagsági jogviszony utódlása kevésbé bonyolult, mint ahogy az a gazdasági társaságoknál megfigyelhető volt: a társulati tagság az érdekeltségi területen fekvő ingatlan tulajdonlásához kötődik, az ingatlanban való öröklés kiváltja a jogutódlást is.

Tevékenység alapján besorolt speciális társulás a családi gazdaság, ami szerint családi gazdaság a mezőgazdasági igazgatási szervnél családi gazdaságként nyilvántartásba vett mezőgazdasági üzem. ${ }^{774}$ A fogalomból eredően e jogintézménynek is - az előbbi társulási formákkal azonosan - az agrárjoggal van szorosabb kapcsolata, de jogi jellegére tekintettel indokolt e helyütt is tárgyalni. A családi gazdaság tagjait összefoglalóan a gazdálkodó család tagjainak nevezzük, ${ }^{775}$ a családi gazdaságot vezető személy pedig a családi gazdálkodó. ${ }^{776}$ A családi gazdaság nyilvántartásba vételével összefüggő feladatokat azon járási hivatal látja el, amelynek illetékességi területén található a családi gazdaság központja. ${ }^{777}$ A gazdálkodó család tagjai vagyoni, elszámolási viszonyukat szerződésben szabályozzák, ebben rendelkeznek a családtagok például azokról a mezőgazdasági és kiegészítő tevékenységekről, amelyet folytatni kívánnak, a tulajdonukban és a használatukban lévő termőföldterületnek és az annak megműveléséhez szükséges vagyontárgyaknak legalább öt évre a családi gazdálkodó részére történő átadásáról. ${ }^{778} \mathrm{~A}$ családi gazdaság megszűnésének egyik esete az, ha a családi gazdálkodó meghal, és a túlélő családtagok a halotti anyakönyvi kivonat kiállításától számított 60 napon belül nem jelentik be, hogy a családi gazdálkodást folytatni kívánják. ${ }^{779}$ A családi gazdaság nem egyeztethető össze teljesen a 7.3. pontban tárgyalt családi vállalkozással, mert a családi gazdaság csak a mezőgazdasági

\footnotetext{
${ }^{773}$ Csák 305., ÍH 2011.40., ÍH 2016.28. A társulatok kényszertagsági jellegének alkotmányellenességének megállapítására irányuló kérelmet az Alkotmánybíróság elutasította. (809/B/2004. AB határozat)

${ }_{774}$ 2013. évi CXXII. tv. 5. § 4. pont; Ugyanezen $\S 20$. pontja határozza meg a mezőgazdasági üzem fogalmát, ami az azonos céllal működtetett mezőgazdasági termelési tényezök (föld, mezőgazdasági felszerelés, egyéb vagyonelemek) szervezeti alapegysége, amely a gazdasági összetartozás révén gazdálkodási alapegység is. A családi gazdaságokkal kapcsolatban lásd még: Kurucz 2007a. 52-54., Kurucz 2007b. 26-29., Fézer et al. 2014. 29-30.

${ }^{775}$ 2013. évi CXXII. tv. 5. § 8. gazdálkodó család tagjai: a családi gazdálkodó, továbbá annak olyan házastársa, élettársa, kiskorú gyermeke, unokája, valamint a gazdálkodó család tagjaként bejelentkezett nagykorú gyermeke, szülöje, nagyszülöje, testvére, ahol a gyermeken az örökbe fogadott és a nevelt gyermeket is érteni kell.

${ }_{776}$ 2013. évi CXXII. tv. 5. § 5. pont

${ }^{777}$ 326/2001. (XII. 30.) Korm. r. 2. § (1) bek.

${ }^{778} 326 / 2001$. (XII. 30.) Korm. r. 3. §

${ }^{779}$ 326/2001. (XII. 30.) Korm. r. 5. § (1) bek. c) pont
} 
termeléshez kapcsolódó tevékenységet láthat el, míg a családi vállalkozások tevékenységi köre kiterjedhet bármilyen jogszabály által nem tiltott tevékenységre, illetve engedélyhez kötött tevékenységre is, amennyiben a társaság rendelkezik a szükséges engedéllyel.

\subsubsection{Létszám szerint}

A társulásban résztvevők száma alapján történő csoportosítást tekintve a társulás hétköznapi jelentéséhez képest (kettő vagy több személy valamilyen cél érdekében történő állandó vagy ideiglenes jellegü közreműködése) létszámbeli speciális vonása van a Polgári Törvénykönyvben szabályozott egyszemélyes kft-nek és rt.-nek. Az egyszemélyi jellegből eredő sajátosságok figyelembevételével ${ }^{780}$ rájuk egyébként a többszemélyes társaságokra irányadó szabályokat kell alkalmazni. Az eltérések öröklés esetén is megfelelően irányadóak: amennyiben egyetlen személy szerzi meg adott társaság összes üzletrészét, illetve részvényét, egyszemélyes társaság jön létre; ${ }^{781}$ ugyanez igaz, ha öröklés következtében valósul meg ez a szerzés (pl. egy kétszemélyes társaság házastárs tagjai közös veszélyben haltak meg, és egyetlen gyermekük az örökös). Újra többszemélyes társasággá alakul át az egyszemélyes társaság, ha az egyszemélyes társaság tagja meghal, és több örökös is a társaság tagjává válik. Ekkor az alapító okiratot társasági szerződéssé kell alakítani, amivel az egyszemélyes „áltársaság” ténylegesen társulássá válik. ${ }^{782}$ Egyszemélyes kft. esetén is lehet olyan személy, aki a tag halálának bekövetkeztekor magához válthatja az egyetlen üzletrészt, a Ptk. vonatkozó 3:170. § (2) bekezdése nem támasztja azt a követelményt, hogy csak olyan személy jelölhető meg a létesítő okiratban, aki maga is a társaság tagja. Ha egyetlen ilyen személy van, aki él a jogával, a társaság ugyanúgy egyszemélyes marad, míg ha több személy él ezzel a jogosultsággal, akkor többszemélyes társasággá válik. Ha nincs ilyen rendelkezés az alapító okiratban, akkor az örökösi minőség igazolása mellett kérheti az egyetlen tag örököse a tagjegyzékbe tagként való bejegyzést. Először közös tulajdonú üzletrész keletkezik, de már ekkor sem beszélünk egyszemélyes társaságról, hiszen nem az üzletrészek, hanem a jogi személy tagjainak számához igazodik a társaság müködése; ezt követően lehet felosztani, amit érdemes megtenni. A

\footnotetext{
${ }^{780}$ Ptk. 3:208-209. §, 3:323. §

${ }^{781}$ Ptk. 3:208. § (2) bek., 3:323. § (2) bek.

${ }^{782}$ Komáromi - Pázmándi 247.
} 
részvénytársaságoknál nincs olyan rendelkezés, ami lehetővé tenné azt, hogy meghatározott körülmények között valamely személy jogosult lenne arra, hogy a részvényt magához váltsa, ha meghal a részvényes, így ennek a lehetőségnek a hiányával, igazodóan a részvény, mint forgalomképes értékpapír jellegéhez, az örökös(ök) megszerezheti(k) azokat. Az örökösök számától függ továbbra is az, milyen társaság lesz, azaz kell-e alkalmazni az egyszemélyes részvénytársaságra irányadó külön szabályokat.

Ugyancsak létszámbeli különbséget jelent a hagyományos értelemben vett társulásokhoz viszonyítva az egyéni cég, amelyet az egyéni vállalkozói nyilvántartásban szereplő természetes személy alapított, és kizárólag ez az egy tagja lehet. ${ }^{783}$

$\mathrm{Az}$ egyéni cég egyetlen tagjának halála esetén ugyanaz a személyi kör folytathatja e tevékenységet, mint akik az egyéni vállalkozó elhunyta esetére jogosultak: a tag halála esetén özvegye, özvegy hiányában, illetve az ő egyetértésével az örökösök, de csak akkor, ha személyüket tekintve az Evc. tv.-ben meghatározott feltételeket maradék nélkül teljesítik, és ezt az igényüket a haláltól számított 30 napon belül bejelentik a cégbíróságnak. Több örökös esetén (véleményem szerint ideértve azt is, ha az özvegy és az örökösök együttesen szeretnék folytatni az egyéni cég tevékenységét)

- hagyatéki eljárás lefolytatásának hiányában az örökhagyó halálától,

- hagyatéki eljárás esetén a hagyaték teljes hatályú átadásáról rendelkező hagyatékátadó végzés jogerőre emelkedésének napjától,

- öröklési per esetén az ítélet jogeröre emelkedésétől

számított három hónapos határidőig valamennyien a cég tagjává válhatnak, ${ }^{784}$ egyúttal be kell jelenteni azt, ki látja el a vezető tisztségviselő vagy képviselő számára előírt feladatokat. ${ }^{785}$ A határidő leteltét követő időszakra nem tartalmaz rendelkezéseket a törvény, azokat a többi irányadó szabályból kell levezetni, így az alábbi lehetőségek adódnak: valamely, a tevékenységet továbbfolytató örökös az egyéni cég tagjává válik; a cég átalakulásáról döntenek (ekkor bármely gazdasági társasági formát választhatják,

\footnotetext{
${ }^{783}$ Evc. tv. 20. § (1), valamint (4) bek. Az egyéni cég szabályozását tekintve sajátos jogintézmény, az Evc. tv.-n túlmenően meghatározott kivételekkel alkalmazni kell a Ctv.-t, a Ptk. jogi személyre vonatkozó általános és gazdasági társaságokra irányadó közös szabályait, a cég tőkéjéből a tag részére tagsági jogviszonyára tekintettel történő kifizetés vonatkozásában a kft-re vonatkozó szabályokat, végül jogutóddal és jogutód nélküli megszűnés esetére az eljárástól függő rendelkezéseket. Lásd még Sáriné Simkó 12-13.

${ }_{784}^{7} \mathrm{Az}$, hogy egyidejüleg több tagja legyen az egyéni cégnek, kivételes állapot. Lásd Gál 2010. 9.

${ }^{785}$ Evc. tv. 32. §, Gál 2010. 12-13., Fézer et al. 2014. 27.
} 
de az ezekre vonatkozó szabályokat be kell tartani), valamint a részesedés átruházására ${ }^{786}$ kerülhet sor. $^{787}$

\subsubsection{Vagyoni szempontból}

A speciális társulások vagyon alapján történő csoportosítása a magántulajdon és a köztulajdon elhatárolását jelenti, olyan társaságok tartoznak ide, amelyekben részben vagy egészben tag az állam, illetve a helyi önkormányzat, ezek a részesedések egyúttal a nemzeti vagyonról szóló törvény hatálya alá tartozó nemzeti vagyonnak minősülnek. ${ }^{788}$ A korábbi állami vállalatokat nagy részben privatizálták, amelyek pedig részben vagy egészben önkormányzati, állami tulajdonban maradtak, gazdasági társaságokká alakultak át. Így ma az állam és az önkormányzatok gazdasági vállalkozásai magánjogi jogi személyként, gazdasági társasági formákban működnek. Az állami, önkormányzati tulajdonnal való gazdálkodással összefüggő érdekeket pedig oly módon érvényesítik, hogy valamely közigazgatási szerv közvetlenül, vagy valamely vagyonkezelő szerv útján gyakorolja a magánjogi szabályozás körébe sorolható tulajdonosi jogokat. ${ }^{789}$ Az állam nemcsak alapíthat társaságot, hanem törvényes öröklés esetén is taggá válhat valamely gazdasági társaságban. Az öröklés jogcíme lehet végintézkedésen alapuló öröklés, de gyakoribb a törvényes öröklés: más örökös hiányában ugyanis az állam a törvényes örökös, akit mint törvényes örököst az örökség visszautasításának joga nem illet meg. ${ }^{790}$

Tehát ha a hagyatékban társasági részesedés van, a társasági formának megfelelően taggá válhat az állam is. A Magyar Állam tipikusan kft.-ben vagy zrt.-ben tag, ilyen társaságokat alapít, azonban egyéb társasági formában, például betéti társaságban is taggá válhat. A helyzet valódi fennállását, és nem csupán hipotetikus voltát bizonyítja az, hogy az MNV Zrt. a rábízott vagyonában 2017-ben összesen 237 olyan, az állam tulajdonába került társasági részesedést tartott nyilván, amelyeket öröklés útján szerzett meg. Éves szinten átlagban 100-120 különböző értékű és tulajdoni arányt megtestesítő társasági részesedést örököl az állam. ${ }^{791}$

\footnotetext{
${ }^{786}$ Evc. tv. 30. § (7) bek.: Egyéni cég vagyoni betétje kizárólag egyéni vállalkozóra ruházható át.

${ }^{787}$ Vö. Körösy

${ }^{788}$ Nvt. 1. $§(2)$ bek. c) pont

${ }^{789}$ Fazekas (szerk.) 70-71.

${ }^{790}$ Ptk. 7:74. §

${ }^{791}$ Boros 8 .
} 
Öröklés útján számos olyan társasági részesedés is állami tulajdonba kerül, amely társaságok tevékenységi köre szempontjából nem szükségszerü az állami szerepvállalás, itt bármilyen tevékenységet végző társaságra gondolhatunk. Megvalósulhat az az eset, miszerint azért örököl az állam, mert az örökhagyó öröklésre jogosult rokonai, hozzátartozói visszautasítják az örökséget annak túlterheltsége miatt, a hagyatéki vagyonban pedig van társasági részesedés. Az államnak sem érdeke, hogy egy veszteséges társaság tagja legyen, az nem lehet kötelező; ezért dönthet úgy, hogy nem lép be a társaságba. Ebben az esetben irányadó a Ptk. 3:151. § (2) bekezdése, ami alapján hagyatéki tartozás lesz a kielégítetlen hitelezői követelés, abban a részben, ami az elhunyt tagra esett. Ez olyan polgári jogi jogviszonyból fakadó kötelezettség lenne, ami költségvetési fedezet hiányában is terhelné az államot, ${ }^{792}$ de az államháztartásról szóló 2011. évi CXCV. törvény 32. § c) pontja ezt a fogalmat leszúkíti az állammal szemben folyamatban lévő peres ügyekkel és az állam által fizetendő kártérítésekkel, kártalanításokkal, továbbá sérelemdíjakkal kapcsolatos költségvetési kiadásokra. ${ }^{793}$ Mindehhez kapcsolódóan az Ávtv. 29. § (1) bekezdésében foglalt szabály is felülírja a Ptk.-t, mert az állam - a törvényes képviseletét ellátó szerv útján - csak olyan gazdálkodó szervezetben vehet részt, illetve olyan gazdálkodó szervezetet alapíthat, amelyben felelőssége nem haladja meg vagyoni hozzájárulásának mértékét. Az Ávtv. rendelkezése azt is jelenti, hogy az állam nem válhat kkt tagjává, illetve bt beltagjává sem, ha a hagyatékban e tagi pozíciókkal kapcsolatos részesedés van. Mindezek tehát azt jelentik, hogy társasági részesedések öröklése esetén a Ptk. 3:406. § kiüresedik.

Az államot ugyan magának az örökség visszautasításának joga nem illeti meg, tehát Magyarországon semmiféleképp nem keletkezhet uratlan hagyaték, de az a speciális jog megilleti az Ávtv. alapján, hogy az állam, mint törvényes örökös nevében az MNV Zrt. az öröklésről az örökhagyó utolsó belföldi lakóhelye, ennek hiányában a hagyaték fekvési helye szerinti helyi önkormányzat, ingatlan esetében pedig annak a fekvési helye szerinti helyi önkormányzat javára lemondjon. ${ }^{794}$ Ez a társasági részesedések vonatkozásában a társaság székhelye szerinti helyi önkormányzatot jelenti, az állam részesedésszerzéséhez viszonyítva a társaság már végezhet olyan tevékenységet, ami az önkormányzati szerepvállalás szempontjából megfelelő lehet. Ez

\footnotetext{
${ }^{792}$ Ptk. 3:406. §

${ }^{793}$ Pázmándi 2014a. 1056-1057.

${ }^{794}$ Ávtv. 36. § (5) bek.
} 
a lemondás nem egyenlő azzal a lemondással, ami kiesési ok, ${ }^{795}$ a leendő örökhagyó és az utána törvényes öröklésre jogosult közötti írásbeli megállapodás. Ha nem ez lenne az értelmezés, akkor az állam nem válhatna szükségképpeni törvényes örökössé, és a magyar ipso iure öröklési rendszer ellenére uratlan hagyaték keletkezhetne, ami még az államnak sem kellene, mivel „lemondott” róla.

$\mathrm{Az}$ állami részvétellel müködő társaságoknál további öröklési jogi vetületek is felmerülnek: a köztulajdonban álló gazdasági társaságok takarékosabb müködése vonatkozásában külön törvényt hoztak, amely pontosan meghatározza, mely társaságokat kell a törvény alanyi hatálya alá tartozóknak tekinteni. ${ }^{796}$ E törvény alapján fö szabály szerint az ilyen tulajdonosi szerkezetű társaságokban kötelező felügyelőbizottságot létrehozni, ez alól az egyik kivétel, ha öröklés útján szerez többségi befolyást az állam, és a tulajdonosi joggyakorló a szerzéstől számított 6 hónapon belül a társaság jogutód nélküli megszüntetéséről döntött, ha ez nem valósul meg, úgy a fő szabályt kell alkalmazni, létre kell hozni a felügyelöbizottságot. ${ }^{797}$ További specialitás található az Nvt.-ben, hogy meghatározott jogcímek kivételével, beleértve az öröklést is, nem szerezhet részesedést olyan társaságban az állam/helyi önkormányzat, illetve olyan gazdasági társaság, amelyben az állam/helyi önkormányzat az Nvt. szerinti többségi befolyással rendelkezik, ha annak a társaságnak valamely nem természetes személy tagja nem átlátható szervezet. ${ }^{798}$ Ha van ilyen tagja ezeknek a társaságoknak, a társaság köteles haladéktalanul intézkedni részesedése megszüntetése érdekében. ${ }^{799}$

Ha a részesedésszerzést követően válik nem átláthatóvá valamely nem természetes személy, az állami/helyi önkormányzati tulajdonos kezdeményezi a társasági szerződés felülvizsgálatát és a gazdasági társaság tulajdonosi szerkezetének az Nvt.-ben foglalt átlátható szervezetre vonatkozó előírásainak megfelelő átalakítását. ${ }^{800}$ Ugyanezeket a szabályokat kell alkalmazni akkor is, ha az Nvt. szerinti többségi befolyással rendelkezik az állam/helyi önkormányzat tag. ${ }^{801} \mathrm{Nem}$ tesz különbséget a törvény a törvényen és a végintézkedésen alapuló öröklés között, bármelyik jogcímen következzen be az öröklés, alkalmazni kell a törvényben meghatározott szabályokat.

\footnotetext{
${ }^{795}$ Ptk. 7:4. § (2) bek. c) pont; Ptk. 7:7-7:9. §

796 2009. évi CXXII. tv. $1 . \S$ a) pont

${ }^{797}$ 2009. évi CXXII. tv. 4. §

${ }^{798} \mathrm{Az}$ átlátható szervezet fogalmát lásd Nvt. 3. § (1) bek. 1. pont

${ }^{799}$ Vö. Nvt. 8. §

${ }^{800}$ Nvt. 8. $\S(2)$ bek.

${ }^{801}$ Nvt. 8. § (3)-(4) bek.
} 
Ha végrendeletben valamely központi költségvetési szervet neveznek meg örökösként, akkor a társasági részesedés állami tulajdonba kerül azzal, hogy az MNV Zrt. nem visszterhes megbízási szerződést köt az adott költségvetési szervvel, tekintettel arra, hogy az Nvt. szabályai szerint ${ }^{802}$ gazdasági társaságbeli részesedés nem lehet vagyonkezelés tárgya. Amennyiben ezt a részesedést később értékesítik, úgy annak bevétele a kedvezményezett költségvetési szervet illeti meg. ${ }^{803}$

Összegezve megállapítható, hogy a Ptk. a korábbi jogi helyzettel megegyezően az államnak speciális szerepet ad a törvényes öröklés folyamatában, amihez igazodik az, hogy nem utasíthatja vissza az örökséget. Ezt figyelembe véve kell elemezni az állami szerepvállalást azon gazdasági társaságokban, amelyekben öröklés útján szerezhet részesedést, egyúttal figyelembe kell venni a Ptk.-n kívüli jogszabályokat is a megfelelő összkép érdekében.

Az állam az osztrák öröklési jogban is sajátos pozíciót foglal el: a módosított öröklési jogi szabályok alapján az állam elnevezése der Bund (a szövetség), amely névváltoztatás a jogintézmény tartalmát tekintve nem jelent változást, tulajdonképpen a korábbi jogértelmezésnek megfelelő gyakorlat beültetése. Az állam csak akkor sajátíthatja el a hagyatékot, ha nincs más öröklésre jogosult és senki más nem akarja azt megszerezni, ${ }^{804}$ ilyen más személynek minősül még a hagyományos vagy a kötelesrészre jogosult, ${ }^{805}$ azaz az állam soha nem válik örökössé a magyar joggal ellentétben. Ez azt jelenti, hogy nem lesz erre kötelezett, valamint a bizonyos elemeiben eltérő társasági jogi szabályozása miatt - a közkereseti és a betéti társaság ex lege megszünik valamely tag halálával, ${ }^{806} \mathrm{de}$ az üzletrész ${ }^{807}$ és a részvény ${ }^{808}$ örökölhető kisebb a valószínűsége, hogy az osztrák állam társasági részesedést szerezzen valamely tag halála folytán.

\subsection{A családi vállalkozások}

Az örökhagyó tag halála nemcsak a családra, hanem a társulásra is jelentős hatást gyakorolhat, különös társasági szerződési elöírások hiányában a társasági jogi és

\footnotetext{
${ }^{802}$ Nvt. 8. $\S(7)$ bek.

803 Ávtv. 28. § (5) bek.

${ }^{804}$ ABGB 750. §, Schauer - Motal - Reiter - Hofmair - Wöss 51.

${ }^{805}$ Welser 532.

${ }^{806}$ UGB 131. § 4. pont, UGB 161. § (2) bek.

${ }^{807}$ GmbHG 76. § (1) bek.

${ }^{808}$ Kalss - Nowotny - Schauer 3/122.
} 
az öröklési jogi szabályok érvényesülnek, amelyek alapvetően eltérő céllal rendelkeznek. A társasági jog szabályozásának célja a társaságban résztvevők különböző érdekeinek összehangolása, az egyensúly biztosítása, míg az öröklési jog célpontjában az elhunyt hagyatékának, benne a társasági részesedésének, elosztása áll. Tekintettel arra, hogy a társasági jogviszony létrejöttével egy alapvetően tartós jellegü jogviszony létesül a többi üzlettárssal is, miután ezeknek is megvannak a saját érdekeik, adott esetben befolyásolni szeretnék a jogutódlást. ${ }^{809} \mathrm{Az}$ örökhagyó még életében érvényesítheti végrendelkezési szabadságát, vagyonának (ebben társasági részesedésének) halála esetére történő elosztásának jogát, ${ }^{810}$ ugyanakkor, ha ez iránt életében nem tett lépéseket, úgy a társasági jogot és a törvényes öröklésre vonatkozó jogot kell alkalmazni. ${ }^{811}$ Az örökösök érdeke a hagyaték megszerzése, és az azzal való szabad rendelkezés, a kötelesrészre jogosultaké a kötelesrészi igények kielégítésére rendelkezésre álló tiszta vagyon törvény alapján őket megillető részének megszerzése. A vállalkozás érdeke a hatékony és megfelelő döntéshozatal és ügyvitel, míg az üzlettársaké az, hogy befolyást tudjanak gyakorolni a mindennapi működésre. ${ }^{812}$

Jelentős szerepet tölthetnek be a vidéki népesség megtartásában a helyi családok által müködtetett családi vállalkozások, amelyek fontos szerepet töltenek be a gazdaságban, valamint javíthatják a müködési területük szociális és kulturális állapotát, ezáltal az adott régió szerves társadalmi képződményeivé válhatnak. ${ }^{813} \mathrm{E}$ vállalkozások egyik legfontosabb, saját túlélésükhöz szükséges ismérve a megfelelő forrás biztosítása, amelyhez az Európai Unió több alkalommal is próbált segítséget nyújtani. ${ }^{814}$

A családi vállalkozás fogalma nem jelenik meg jogszabályi szinten, még a kisés középvállalkozásokról, fejlődésük támogatásáról szóló 2004. évi XXXIV. törvényben sem, amelybe a társaságra vonatkozó jellemző jegyek beilleszthetők lettek volna. Ennek ellenére a joggyakorlatban több alkalommal használják a kifejezést, ${ }^{815}$ míg pontos fogalomalkotással nem találkozhatunk. Kérdéses, mennyire szüken, vagy éppen tágan értelmezzük a család fogalmát, valamint ezekhez képest mennyire illeszthetők be az

\footnotetext{
${ }^{809}$ Kalss - Probst 654., Guggenberger 345.

${ }^{810}$ Müller 309.

${ }^{811}$ Zeiss 324-326.

${ }^{812}$ Kalss - Probst 655., Probst 341.

${ }^{813}$ Kalss - Probst 302. Ugyanez jegyezhető meg a szűkebb tevékenységi kört felölelő családi gazdaságok kapcsán is, lásd Kurucz 2015. 145.

${ }^{814}$ Lásd például a Tanács határozata (2000. december 20.) a vállalkozásokra és különösen a kis- és középvállalkozásokra (kkv-kre) vonatkozó többéves programról (2001-től 2005-ig), a célkitüzések a 2. cikkben olvashatók.) Idézi Miskolczi Bodnár 2004. 208. Jelenleg erről az 1287/2013/EU rendelet tartalmaz szabályokat.

${ }^{815}$ FIT-H-PJ-2014-284.; BDT 2005. 1288.; ÍH 2009. 130.
} 
alábbi osztrák megoldások. A fogalom használata ellenére a döntésekből magukból sem derül ki.

Az osztrák és a német jogirodalom a magyarhoz képest többet foglalkozik a családi vállalkozásokkal, mint lehetséges társulási formákkal. Ezek a vállalkozások a többi, hagyományos értelemben vett gazdasági társaságtól tulajdonosi körükben és a társaságok céljaiban különböznek. Az ilyen társaságoknak nem az az elsődleges célja, mint a többi profitorientált társaságnak, hogy minél gyorsabban a lehető legmagasabb nyereségre tegyenek szert, hanem müködtetésük folyamán jelentős szerepet játszanak a következő generációkról való, hosszú távú gondoskodásnak, a családtagok vagyoni biztonságának, a családi vagyon megőrzésének elvei. ${ }^{816}$ Ezek a társaságok gyakran kevesebb taggal rendelkeznek, mint a nem családi vállalkozások. ${ }^{817}$

E vállalkozásoknak nincs jogszabályban lefektetett fogalmuk, a vonatkozó szakirodalomban különböző meghatározásokat találunk. Az ún. név szerinti családi vállalkozások cégnevében egy család neve szerepel; a családi ellenőrzés alatt álló családi vállalkozásokban maximum három természetes személy a szavazatok legalább 50\%-ával rendelkezik; míg vannak olyan családi vállalkozások, hogy szintén a szavazatok legalább 50\%-ával rendelkező tulajdonosok, akik ugyanannak a családnak tagjai, a társaság vezetésében is részt vesznek. További fogalmi ismérvként jelölhető meg, hogy a családtagok akarata elsődlegesen arra irányul, hogy mint az egész család, a társaságot, túlnyomó többségben a legfelsőbb szinten irányítsák, ${ }^{818}$ fennáll valamint annak a szándéka is, hogy a vállalkozást több generáción át müködtessék, és az a család ellátását is szolgálja. ${ }^{819} \mathrm{~A}$ családi vállalkozásoknál nemcsak a vezetés átadása, hanem a társasági vagyon generációk közötti átadása is rendkívül fontos azok megmaradása érdekében. ${ }^{820}$ Tehát az objektív kritériumokhoz, úgy, mint a részesedés nagysága, ezen keresztül a szavazásra való jogosultság mértéke, a vezető- és ellenőrző pozíciók kézben tartása, párosulnak szubjektívnek tekinthető vonások (a cég folytatására irányuló akarat, felelősségvállalás) ahhoz, hogy a társaságot családi vállalkozásnak tekinthessük. ${ }^{821} \mathrm{Nem}$ zárható ki tehát a családi vállalkozássá minősítés abban az esetben sem, ha adott társaság társasági részesedései nem egy család tulajdonában állnak, hanem több

\footnotetext{
${ }^{816}$ Kalss - Probst 2.

${ }^{817}$ LeMar 6.

${ }^{818}$ Kalss - Probst 9-12.

${ }^{819}$ Kalss - Probst 16.

${ }^{820}$ LeMar 197.

${ }^{821}$ Kalss - Probst 17.
} 
családéban, illetve a családhoz képest idegen személyek is a társaság tagjaivá váltak. ${ }^{822}$ Megjegyzi azt is az irodalom, hogy családi vállalkozások esetében nem feltétel az, hogy többszemélyes társaság legyen. ${ }^{823} \mathrm{Az}$ osztrák közgazdasági- jogi elemzés esetleges magyar átvétele nem eredményezne idegen hatást, hasonló megfontolások a magyar cégek vonatkozásában is megállnák a helyüket.

Jelentős kérdés ezeknél a jellemzően kkv-nak minősülő vállalkozásoknál a sikeres utódlás véghezvitele, ${ }^{824}$ aminek súlyponti kérdése, egyben problémája a kötelesrészi igények kielégítése különösen azoknál a társaságoknál, ahol jelentős apportaránnyal bírnak a termőföldek (földbirtokok), és amely problémák akkor merülnek fel, ha a nyereségből nem képesek ezeket a kötelesrészi igényeket kielégíteni, és a kötelesrészre jogosulttal nem tudnak megegyezni. ${ }^{825}$ Megjegyzendő, hogy a magyar termőföld forgalmáról szóló törvény értelmében a jogi személyek csak a törvényben meghatározott kivételekkel szerezhetnek földtulajdont. ${ }^{826} \mathrm{~A}$ vállalkozások sokszor nem rendelkeznek meghatározott tárgykörökben belső szabályozással, amelyek szükség esetén kellenének. E hiányok közé tartoznak a vitarendezési mechanizmusok vagy éppen az utódlás kérdésköre, amelyek rendezésére gazdasági, de inkább személyes és érzelmi alapokon nyugodva nem is készülnek fel. A keretszabályozás nem mindig tudja ezeket megnyugtatóan kezelni, amik a családi vállalkozások megszűnését eredményezhetik, de ezeket a kereteket pontosan ismerni kell, amikre alapozva a hiátusok kiküszöbölhetőek. ${ }^{827}$

A magyar jogirodalom hiányosságai ellenére meggyökeresedett ez a típusú (de a hagyományos gazdasági társaságokhoz képest nem eltérő, hanem ugyanolyan formákban müködő) társasági forma. Ausztriához hasonlóan Magyarországon is elterjedt, a hazai vállalatok hetven százaléka van családi tulajdonban, a GDP több mint felét adják, a munkavállalók felét dolgoztatják. Magyarországon is a generációváltás az egyik legjelentősebb kihívás, ennek ellenére nincs kidolgozott utódlási terv, ami miatt kétharmaduk megszünhet e folyamat során. ${ }^{828}$

A problémák megoldásának egyik eszköze az öröklési szerződés lehet. A többi átruházó szerződéshez képest az az előnye, hogy a családi vállalkozásban részt vevő tag

\footnotetext{
${ }^{822}$ Kalss - Probst 77.

${ }^{823}$ Kalss - Probst 12-13., uo. 191.

${ }^{824}$ Diwisch - Voithofer - Weiss 2.

${ }^{825}$ Kalss - Probst 3. A 2017. január 1-jétől hatályos osztrák öröklési jogi szabályok kötelesrészre vonatkozó rendelkezéseinek társasági jog körében való alkalmazásra hívja fel a figyelmet Graisy 5-6.

${ }^{826}$ 2013. évi CXXII. törvény 9. § (1) bek. c) pont

${ }^{827}$ Kalss - Probst 4.

${ }^{828}$ http://www.vg.hu/kkv/optimistak-a-csaladi-cegek-475310 Letöltés ideje: 2016 . november 9.
} 
továbbra is maradhat ebben a minőségében egészen haláláig, de az utódlásról is gondoskodott. A szerződésben lehetőség van a vagyon egy részére nevezni az örököst, és ennek ellenértékének megfelelően lesz jogosult tartásra, gondozásra, életjáradékra attól függően, hogy az adott szituáció melyiket kívánja meg, és miben állapodik meg az örökhagyó tag és a szerződéses örökös. A hazai ilyen jellegü vállalkozásoknál is szempont lehet az, hogy a családtagok vigyék tovább, és megfelelő rokoni kapcsolatok esetén a leendő örökhagyó is ennek figyelembevételével kívánja utódját kiválasztani. Az öröklési szerződéssel arra is lehetőség nyílik, hogy a vállalkozás mindennapi ügyvitelében vagy annak foglalkozási területében jártas személlyel (lehetőség szerint valamely családtagjával) kerüljön sor a megállapodásra. E társaságok az utódlás megfelelő tervezése esetén nagyobb eséllyel működhetnek tovább, munkát adva ez által a munkavállalóknak, támogathatják a helyi gazdaságot és kultúrát (pl. különböző rendezvények pénzügyi fedezetének nyújtása).

Ahogy az a 8.3.2. részben kibontásra kerül, meg lehet valósítani azt a társasági szerződésben, miszerint korlátolt felelősségü társaságnál meghatározott jogcímek vonatkozásában a tagok kizárják az üzletrész átruházását, így ez alapján például az öröklési szerződés nem lehet jogcím. Ebben az esetben meg lehet engedni azt, hogy más jogcímen - különbséget téve a végintézkedések között - végrendelettel bizonyos személy javára juttassa az örökhagyó a családi vállalkozásbeli részesedését, ugyanakkor nem megvalósítható, hogy a 4.3.2.1. pont alatt tárgyalt jogesethez hasonlóan az üzletrészek vonatkozásában a másik tag általi öröklésről rendelkezzék a társasági szerződés, ezt meglátásom szerint a családtagok által müködtetett társaságoknál sem megengedett. A társasági szerződés célját tekintve jogalany létrehozására és annak szervezetének, működésének meghatározására irányul, nem a természetes személy tagok halála esetére irányadó rendelkezéseket kell tartalmaznia. Erre más megfelelő eszközöket kínál a jog, például a végrendeletet. Mindezeket mutatis mutandis a többi társaság vonatkozásában is meg lehet jegyezni.

Az osztrák egyszemélyes társaságok, mint létszám szerint csoportosított speciális társaságok és a családi vállalkozások jegyeinek keveredése található meg az egyszemélyes családi társaságoknál. Ezek esetében jellemző az, hogy az örökhagyó tag halála után nem olyan személy lesz a társaság tagja, mint aki korábban például vezető tisztségviselő volt, mert adott esetben az örökhagyó maga vezette a társaságát, vagy éppen a családi viták elkerülése érdekében egy, a családjához képest idegen személyt kért meg erre a feladatra. Az örökösök ez által nem is láthattak a cég mindennapjaiba, 
így azt nekik meg kellene ismerni, hogy teljes mértékben átvehessék a korábbi egyszemélyi tulajdonos pozícióját, elkerülve ezzel a társaság eladósodását. Egyetlen lehetséges örökös esetén nem probléma a jogutódlás eldöntése, csak az lehet kérdéses, hogy valóban jogelődje helyére kíván-e lépni, és alkalmas-e erre a posztra. ${ }^{829}$ Több örökös esetén az lehet kérdés, hogy mennyien szeretnének taggá válni, illetve a tulajdonosi pozíción kívül mennyien kívánnak ténylegesen részt venni a társaság vezetésében. ${ }^{830}$ A munka gördülékeny folytatása érdekében célszerű ezeket a kérdéseket még az örökhagyó életében tisztázni, vagy ha erre már nincsen lehetőség, úgy a családi vállalkozás fennmaradásának érdekét szem elött tartva minél hamarabb, lehetőleg jogvita nélkül rendezni a jogutódlás folyamatát. Mindezek túlmenően kiskorú örökös esetén, ha rájuk vonatkozóan van valamilyen társasági szerződésbeli előírás, akkor azokat is be kell tartani. Nem lehet természetesen figyelmen kívül hagyni a törvényes képviselet kérdéskörét sem, mert adott esetben érdekellentét állhat fenn a szülök, illetve a szülök és a gyermekek között, ${ }^{831}$ például ha valamely nagyszülő végrendeletében unokáját tette örökösévé. Többszemélyes társaságoknál is ugyanúgy felbukkannak a tulajdonosi körre és az üzletvezetésre irányadó problémák, de abból a szempontból súlyozottabban, azaz azzal a különbséggel, hogy itt vannak más tagok is, akiknek különösen a személyegyesítő társaságoknál jelentős beleszólásuk van a társasági részesedés jogutódlásába, ha a társasági szerződés azt lehetővé teszi, meggátolva akár az eredményes és minél korábbi döntéshozatalt.

Mindezek alapján megállapítható, hogy a családi vállalkozás jogi helyzete speciális abban az értelemben, habár nincsen jogszabályban meghatározott definíciója, de a bírói gyakorlatban és a hétköznapi életben gyakran használt kifejezés, még sincs a fellelhető jogesetekben különösebb jogkövetkezménye, pontosabban eredménye annak, ha egy társaságról megállapítják annak családi vállalkozás mivoltát. Az osztrák jogirodalom nyomán célszerünek találom egy átfogó, nem túl kazuisztikus fogalom meghatározását, amelyhez - a családi gazdaság mintájára - eltérő kedvezmények, pl. adójogi tehercsökkentés, párosulhatnának.

Ennek a fogalomnak mindenféleképpen elemévé kellene tenni a családi jelző meghatározását, itt nem csupán a Ptk. 8:1. § (1) bekezdésének 2. pontja szerinti hozzátartozók közötti társulás képezhetné az ilyen jellegű minőség odaítélését, hanem

\footnotetext{
${ }^{829}$ Kalss - Probst 286.

${ }^{830}$ Kalss - Probst 287.

${ }^{831}$ Kalss - Probst 287.
} 
azon személyek között, akik rokonok a Ptk. 4:96. § alapján. A kiterjedt családi kapcsolatok feltérképezhetetlenségének érdekében ezt a kört a törvényes öröklésre jogosultak körére lenne célszerü szorítani, ami azt jelenti, hogyha azok válhatnának ugyanazon családi vállalkozás tagjaivá, akik egymás után - az őket megelőző személyek kiesése esetére - a törvény alapján örökölnének (dédszülöi parentéla). Meglátásom szerint a rokoni körbe még ezek a személyek ismerik egymást, és tarthatják jobban a kapcsolatot.

A vállalkozás fogalmi elem helyett, miután a vállalkozás a fogyasztói szerződésekhez kapcsolódó terminus technicus - a cég kifejezés használatát tartom megfelelőnek. Ez már csak azért sem okozhat fogalmi diszkrepanciát, mert az osztrák minta kitételei alapján - amiknek átvétele támogatandó - a cégek azok a jogi formák, amely formákban az ilyen jellegü társulásoknak létjogosultsággal rendelkeznek, ahol ugyan nem teljes, de tolerálható mértékben, az adott cég sajátosságait teljes mértékig tiszteletben tartva - a vagyongyarapítás mellett a személyes közremüködésnek is helye lehet.

Mindezeknek a külön jegyeknek a társasági pozíciók öröklésére is kihatással van: az adott cég sajátosságaira figyelemmel, amennyiben van neki öröklésbeli specialitása, és nem kizárt a jogutódlás lehetősége, úgy ebben az adott társaság tagjai törvény erejénél fogva elsőbbséget élveznének, még ha egyébként törvényes öröklés alkalmával csak egy olyan parentélában foglalnának helyet, amelynek a tagjai nem örökölnek; ezzel is eltérítve a cégbeli részesedésen kívüli vagyontárgyakra irányadó öröklési jogi szabályokat. A fogalom jogszabályi szintü megalkotásának akkor van értelme, ha ahhoz további joghatás is füződne, ilyen egyrészt a speciális jogutódlás bevezetése, valamint például a már említett adókedvezmény meghatározása.

\section{4. Összegzés}

$\mathrm{Az}$ értekezésben speciális társulásokként meghatározott személy- és vagyonegyesülések öröklési jogi szempontból történő megközelítése sajátos összképet nyújt, amely nem csupán abból ered, hogy egymáshoz képest különféle típusok kerültek e fejezetben tárgyalásra. Konzekvenciaként levonható, hogy a személyegyesítő gazdasági társaságokhoz hasonlóan azokban a társulásokban, ahol valamely kiemelt csoportosítási jellemző alapján a társulásban közremüködő személy kiléte fontos, példának okáért szakmai képzettség miatt, ott ennek a személynek halála utáni speciális 
társaságbeli jogutódlás is kötöttebb. Ha egyáltalán az örökösök a társaságban jogutóddá is válhatnak, akkor az is inkább társaságbeli új pozíció létrejövetelét eredményezi, mintsem az örökhagyó jogviszonyának szerves folytatását jelenti, lásd például a polgári jogi társaságot. Ahol viszont a társaság megkülönböztető ismérvét egy, a személyeken kívüli tényező alapozza meg, ott a jogutódlás is kevésbé kötött, ilyen pl. az erdőbirtokossági társulat. 


\section{Az öröklési szerződés szerepéről a társasági jogban}

\subsection{Bevezetés}

Az örökölhető vagyonelemek egyik jelentős ismérve az, hogy forgalomképes jogosultságok és kötelezettségek. Az egyes társasági formákhoz kapcsolódó részesedések öröklése nem mindegyik esetben türi az ipso iure tulajdonosváltozást, az átszálláshoz feltétel társulhat, míg másokat az örökösök könnyebben meg tudnak szerezni. Az öröklési jogi forgalomképességgel rokon vonásokat mutat a társasági jogi forgalomképesség, azzal, hogy utóbbiban sokkal jelentősebb szerepe van a jogviszonyt alakítóknak, ugyanis a jogszabályok nagyobb szabadságot adnak: a részvények - a dolgozói részvények és egyéb korlátozottan forgalomképessé alakított részvények kivételével - szabadon átruházhatóak; az üzletrészek is forgalom tárgyai lehetnek, de e jellegük korlátozható, pl. elővásárlási joggal, vagy ha a társasági szerződés adásvételen kívül más jogcímen nem engedi az átruházást, azt más feltételhez kötik, vagy öröklés esetén megváltásra jogosult személyt jelölnek ki; míg kkt. és bt. esetében a társasági részesedés átruházásához a társasági szerződés egyhangú módosítása szükséges. ${ }^{832} \mathrm{~A}$ társasági részesedések átruházás-korlátozásának az a célja, hogy ilyen módon elkerüljék a nemkívánatos személyek társaságba történő belépését, a döntéshozatalban való részvételüket, akár egyszerü, minősített többséget biztosító befolyás szerzését. ${ }^{83}$

Speciális élők közötti, de halál esetére szóló átruházási szerződés az öröklési szerződés, melynek társasági jogban történő alkalmazásával kérdések merülhetnek fel. Ezekre törekedek válaszokat találni ebben a fejezetben.

\section{2. $\quad$ Az öröklési szerződésről általában}

A Ptk. szerint az öröklési szerződéssel az örökhagyó a vele szerződő felet a magának, illetve a szerződésben meghatározott harmadik személynek nyújtandó tartás, életjáradék, illetve gondozás ellenében - vagyona, annak egy meghatározott része vagy meghatározott vagyontárgyak tekintetében - örökösévé nevezi; a másik fél kötelezettséget vállal a tartás, életjáradék, illetve gondozás teljesítésére. ${ }^{834}$ A szerződés

\footnotetext{
${ }^{832}$ Papp 2011a. 130.

${ }^{833}$ Török T. 2011. 3.

${ }^{834}$ Ptk. 7:48. § (1) bek.
} 
sajátossága, hogy az örökhagyó az öröklési szerződésben bármilyen végrendeleti rendelkezést tehet, míg az örökhagyóval szerződő félnek az öröklési szerződésbe foglalt végrendeleti rendelkezése érvénytelen. ${ }^{835} \mathrm{Az}$ örökhagyó szempontjából a formáját tekintve a szerződés egyben tehát végintézkedés, ugyanakkor tartalma szerint a tartási vagy az életjáradéki szerződésnek speciális típusa, ezért e szerződések szabályait is megfelelően figyelembe kell venni, ${ }^{836}$ ezeken kívül még szerencseszerződés is, amelyben a szolgáltatás és az ellenszolgáltatás aránya a szerződés megkötésekor fogalmilag nem vizsgálható. ${ }^{837}$ A végintézkedési jelleg abból is kitűnik, hogyha az öröklési szerződés érvénytelen, de egyébként az írásbeli magánvégrendelet kellékeinek megfelel az okirat, akkor azt ekként kell elbírálni. ${ }^{838}$ A szerződés alakiságára vonatkozóan, hogy az érvényes legyen, az írásbeli végrendeletre vonatkozó szabályokat azzal az eltéréssel kell alkalmazni, hogy a szerződésnek akkor is a más által írt végrendelet alaki érvényességi feltételeinek kell megfelelnie, ha az valamelyik fél saját kézírásával készült. ${ }^{839}$

Az öröklési szerződéssel átruházott vagyontárgy nemcsak ingó és ingatlan lehet, hanem bármely olyan vagyonelem, ami öröklés útján átszállhat, hiszen az öröklési szerződéssel a szerződő fél, ahogy az a fogalomból is kiderül, az örökhagyó örökösévé válik akkor is, ha egyébként nem minősülne törvényes örökösének, ugyanúgy, mint a többi végintézkedési formánál. Nem feltétel, hogy a teljes vagyonra nézve váljon örökössé, elegendő bizonyos vagyontárgyak meghatározása, így akár azok lehetnek az örökhagyó üzletrészei, részvényei, stb. és ezeknek a meghatározott vagyonelemeknek megfelelő értékü ellenszolgáltatást kell a szerződéses örökösnek nyújtania.

Tekintettel arra, hogy végintézkedési formáról van szó, fontos fogalmi elem az, hogy az örökhagyót túlélje az örökös. Nem ugyanaz, ha a felek a jogutódlás időpontjául, de nem feltételéül az örökhagyó halálát kötik ki, az ilyen kikötés valójában a szerződés teljesítési időpontjának a meghatározása. ${ }^{840}$

A szerződés megkötése a felek magánautonómiájához tartozó kérdés, abban az esetben, ha megkötötték, akkor a felek eltérő megállapodásának hiányában semmis az örökhagyónak élők között vagy halála esetére az öröklési szerződéssel lekötött

\footnotetext{
${ }^{835}$ Ptk. 7:48. § (3) bek.

${ }^{836}$ Ptk.7:52. §, Anka 2014c. 588.; Vékás - Weiss 2430.; Orosz 2014c. 264. Az öröklési szerződésekkel kapcsolatban lásd még Szalma 377-382.

${ }^{837}$ Vékás - Weiss 2431.

${ }^{838}$ BH 1996. 362.

${ }^{839}$ Ptk. 7:49. § (1) bek.

${ }^{840}$ Vékás - Weiss 2429.
} 
vagyontárgyat elidegenítő vagy megterhelő rendelkezése, ez azonban harmadik jóhiszemű személy visszterhesen szerzett jogát nem érinti. ${ }^{841}$

Amennyiben kiskorúval, mint szerződéses örökössel kötnek öröklési szerződést, akkor az hatósági jóváhagyás hiányában hatálytalan. A jóváhagyással azonban a szerződés annak megkötésének időpontjára visszamenőleges hatályossá válik. ${ }^{842} \mathrm{~A}$ megváltozott jogszabályi környezet folytán már nem vehető figyelembe az a korábbi bírói döntés, amely szerint hatósági jóváhagyás hiánya esetén az öröklési szerződés nem jött létre. Az sem alkalmazható maradéktalanul, miszerint abban az esetben, ha az örökhagyó a teljesítés elfogadásával, mint ráutaló magatartásával is kifejezésre juttatja a szerződéses akaratát, és a szerződéses örökösnek még az örökhagyó életében bekövetkezett nagykorú válásával megszűnt az a feltétel, ami a szerződés létrejöttét akadályozta, az öröklési szerződést visszamenőleges hatállyal létrejöttnek kell tekinteni. $^{843}$

\subsection{A társasági részesedések átruházása öröklési szerződéssel}

Dogmatikai szempontból az átszállás és az átruházás származékos szerzésmódnak minősül; az átszállás általában a jogalany akaratától függetlenül megy végbe jogszabályi rendelkezés, születés, halál, stb., azaz objektív jogi tény következtében, ilyen a társasági jogi szempontból is releváns öröklés és jogutóddal való megszünés. Az átruházás ehhez képest a jogalanyok egyező akarata szerint valósul meg, szubjektív jogi tény alapján. ${ }^{844}$ A társasági részesedések átruházása vonatkozásában utalásokat találhatunk az egyes társasági formáknál, amiket az alábbiakban röviden áttekintünk. Mindezek előtt általánosságban elmondható, hogy nem kizárt a részesedések öröklési szerződés útján történő átruházása, ${ }^{845}$ amit a bírói gyakorlat is alátámaszt nemcsak tartási szerződés, hanem öröklési szerződés vonatkozásában. ${ }^{846} \mathrm{~A}$ társaságokra vonatkozó öröklési jogi szabályok rövid áttekintésén túl az öröklési szerződéseknek ilyen módon történő megjelenését tekintjük át e részben.

\footnotetext{
${ }^{841}$ Ptk. 7:50. § (1) bek.

${ }^{842}$ Ptk. 6:118. § (1) bek.

${ }^{843}$ BH 2012. 170.

${ }^{844}$ Török T. 2011. 3.

845 Például az üzletrészek öröklési szerződéssel való lekötése vonatkozásában lásd Koday 11.

${ }^{846}$ BDT 2007. 1581.
} 
Az öröklési szerződés és a szindikátusi szerződés ismérveinek egybevetése $\mathrm{e}^{847}$ alapján megállapítható, hogy az öröklési szerződésekre jellemző tartalom ugyan szükebb kört képvisel, mint amilyen tartalommal a szindikátusi szerződéseket meg lehet kötni, de előbbi beolvasztható az utóbbi szerződésekbe, mert nem egymásnak ellentmondó szolgáltatásokról van szó, mindkettő bizonyos tekintetben egyfajta együttmüködést takar. Míg a szindikátusi szerződés a társaság tagjainak egymás közötti szerződéses viszonyát rendezi, általában valamilyen többletkötelezettséget tartalmaz, vagy a Ptk.-ban nem található kérdést rendez, addig az öröklési szerződés a szerződéses örökös és az örökhagyó közötti kapcsolat, amely teljesítése során a leendő örökös az örökhagyó javára tartást vagy életjáradékot nyújt. Ez tekintettel a szerződés szerencseelemére, akár hosszabb ideig fennálló szoros kapcsolatot teremt a szerződéses felek között. Ezekkel - ahogy az látható - hatékonyan elő lehet segíteni a jogviták megelőzését és a tag halálának társaságra gyakorolt hatásainak csökkentését.

Lehetőség van arra is, hogy a szerződéses örököst rendelje ki a közjegyző a Hetv. 32. § szerinti ügygondoknak. ${ }^{848}$

\subsubsection{Közkereseti és betéti társaságok esetén}

A közkereseti és a betéti társaságoknál a tag a tagsági jogviszonyon alapuló jogokból és kötelezettségekből álló társasági részesedését vagy annak egy hányadát a társaság más tagjára vagy harmadik személyre ruházhatja át. Az átruházó szerződést írásba kell foglalni. Az átruházó szerződés akkor válik hatályossá, ha a társaság a társasági szerződést az átruházásnak megfelelően módosítja, ${ }^{849}$ a tagváltozás átvezetéséhez - a társasági szerződés módosítása miatt - egyhangú határozathozatalra van szükség. ${ }^{850}$

Átruházási jogcímnek minősül az öröklési szerződés is, mely átruházási szerződéssel kapcsolatos írásba foglalási kényszer azért nem okoz a feleknek többletkötelezettséget, mert már önmagában az öröklési szerződés érvényességi kelléke valamely írásbeli végrendeleti formának való megfelelés, ez pedig jóval túlmutat az egyszerü írásbeliségen, hiszen a társasági részesedés átruházására irányuló szerződés alakiságára nem rendel további feltételt a Polgári Törvénykönyv, ezért más szerződés

\footnotetext{
${ }^{847}$ Nagy Barna - Dúl 8-12.

${ }^{848}$ Debreceni Ítélőtábla Pf. II. 20.644/2015/7.

${ }^{849}$ Ptk. 3:148. §

${ }^{850}$ Ptk. 3:143. $\S(4)$ bek.
} 
esetén elegendő e kritérium. A hatályos és az azt megelőző szabályozások szerint a társasági részesedés korlátozottan forgalomképes vagyoni értékü jog, mivel a tagok döntéséhez, a társasági szerződés tagok általi módosításához kötött a tagcsere. ${ }^{851} \mathrm{~A}$ társasági szerződés módosítása miatt az összes tagnak hozzá kell járulnia az ügylethez, ${ }^{852}$ éppen ezért olyan kikötésekhez, amik a korlátolt felelősségű társaságoknál és a részvénytársaságoknál törvényi szinten is szabályozva vannak, ezeknél a társasági formáknál szükségtelenek. Így nem kell külön a társaság beleegyezéséhez kötni az átruházást (pl. öröklési szerződés útján való átruházásnál), azzal, hogy természetesen nem ütközik jogszabályba, ha a társasági szerződésbe ilyen tartalmú rendelkezést vesznek fel. A társaság beleegyezése vonatkozásában a társasági, de még inkább egy szindikátusi szerződésben (amelyeknek a kötése egyik társasági forma vonatkozásában sem kizárt, de a kkt és bt jellegüknél fogva nem olyan modellel rendelkeznek, amiknél külön megállapodás indokolt lenne) meghatározhatnak olyan feltételeket, amik bekövetkezése esetén minden tagnak hozzá kell járulnia a társasági szerződés módosításához.

Nem szabad azonban elfelejtkeznünk arról, hogy ezeknél a társaságoknál nem válik automatikusan az örökhagyó örököse taggá, ahhoz külön jogügylet szükséges, és a változások átvezetésére szolgál a módosítás. Az öröklési szerződés hatályosulása a többi átruházó szerződéstől eltérő: a társasági szerződés módosítása valójában az örökös tagként való belépését fogja szolgálni, de az öröklési szerződés jellege miatt erre csak az örökhagyó halálát követően kerülhet sor, ha az örökös túléli öt, egy pontosan meghatározott feltételtől függően egy közelebbről meghatározhatatlan időpontban, szemben a többi, általános jellegű átruházó szerződéssel, amelyeknél a szerződéskötő felek életében beállnak a kívánt joghatások. Tekintettel kell lenni arra is, hogy az örökös öröklése jogán is beléphet a társaságba: ${ }^{853}$ látszólag két önálló jogcímen válhat a kkt., illetve bt. tagjává (átruházás öröklési szerződéssel, valamint öröklés folytán), de a szerződés jellege ezt kizárja. Mindenképpen módosítani kell a társasági szerződést, ami pedig az összes tag konszenzusát fogja jelenteni. ${ }^{854}$

\footnotetext{
${ }^{851}$ Boóc 185 .

${ }^{852}$ Ptk. 3:143. § (4) bek.

${ }^{853}$ Ptk. 3:149. §

${ }^{854}$ Ptk. 3:143. § (4) bek.
} 


\subsubsection{Korlátolt felelősségü társaságok}

„Az üzletrész átruházása alapvetően azért igényel sajátos társasági jogi szabályozást, mert bár nem szerződéses viszonyról van szó, a társaság személyegyesítő jegyeket is magán hordozhat, ami azt indokolja, hogy a tagváltozás bizonyos mértékig a többi tag kontrollja mellett történjen. Ez a kontroll különböző erősségű aszerint, hogy a tagok egymás között vagy kívülálló számára ruházzák-e át az üzletrészt. A szabályozás tehát eszerint differenciáltan történik." ${ }^{855}$ Az átruházás tulajdonszerzési módot jelent, amelyhez kapcsolódóan a tulajdonszerzési jogcímeket a Ptk. kötelmi joga tartalmazza, és a jogcímek tekintetében nincs törvényi korlátozás. Konkrét jogeset vonatkozásában mondta ki a jogalkalmazó, hogy az előbbi megállapításnak megfelelően nincs akadálya annak, hogy a kft. tag üzletrészét életjáradék fejében ruházza át. ${ }^{856}$ Habár az öröklési szerződés az öröklési jogi könyvben található, és álláspontom szerint jellege miatt oda is tartozik, át lehet ruházni öröklési szerződés címén az üzletrészeket, már csak azért is, mert az örökhagyó részére nyújtandó szolgáltatásra a kötelmi jogban fellelhető tartási és életjáradéki szerződést kell alapul venni, amelyek szintén jogcímként szolgálhatnak az üzletrész átruházásához. A különbség utóbbi kettő szerződés és az öröklési szerződés között, hogy öröklési szerződés esetén csupán majd csak az örökhagyó halálával szállnak át az örökösre a szerződésben meghatározott vagyontárgyak.

A már említettek alapján helytállóak a BDT 2005. 1107. számon megjelent eseti döntésben foglaltak, amelyek az üzletrész fogalmi jellemzőin keresztül vezeti le az üzletrészek átruházhatóságát: az üzletrész nem ,dolog”, hanem olyan tagsági és vagyoni jogokat megtestesítő vagyoni értékü, immateriális jogosultságok összessége, amely a hasznosítás és rendelkezés (átruházás) során dolog módjára viselkedik. Az üzletrész a társaság tagjai között szabadon átruházható, ${ }^{857}$ míg kívülálló részére pénzszolgáltatás ellenében átruházni kívánt üzletrész megszerzésére a többi tag, a társaság vagy a társaság által kijelölt személy - ebben a sorrendben - az elővásárlási jogra vonatkozó rendelkezések megfelelő alkalmazásával másokat megelőzően jogosult. E jog átruházása semmis. Az üzletrész másokat megelőző megszerzésére irányuló jog a tagokat üzletrészeik egymáshoz viszonyított mértéke szerint, arányosan illeti meg. ${ }^{858} \mathrm{Az}$ üzletrészek pénzszolgáltatás ellenében történő átruházásának Ptk.-beli általános

\footnotetext{
${ }^{855}$ Kisfaludi 2014b. 378.

856 ÍH 2004. 71.

${ }^{857}$ Ptk. 3:166. § (1) bek.

${ }^{858}$ Ptk. 3:167. § (2) bek.
} 
szabályai az öröklési szerződés tekintetében azért nem alkalmazhatóak, mert nem pénzszolgáltatás áll az üzletrésszel szemben, illetve jobban személyhez kötött, mint ahogy az az alapesetben került szabályozásra. Az öröklési szerződés lehet tartási jellegü, a tartás, mint az ellenszolgáltatás fö vonása nem egyeztethető össze a pénzszolgáltatással, utóbbi a tartás pontosan megfogalmazott, a Ptk.-val a korábbiakhoz képest kibővített és a bírói gyakorlatban kimunkált fogalmába nem illeszthető be aggály nélkül. E szerződések másik jellemző típusa az életjáradéki szerződést ötvözi. Az életjáradék ugyan egyfajta pénzszolgáltatás, ami által sokkal inkább piaci jelleget ölt magára, ${ }^{859}$ de véleményem szerint az még szorosan kapcsolódik a szerződéses örökös személyéhez, az örökhagyó nem kíván bárkit örökösévé tenni, ezért köt ezzel a személlyel szerződést. A bírói gyakorlat ${ }^{860}$ az életjáradéki szerződések vonatkozásában az ellenszolgáltatás személyhez tapadó jellegét gyengébbnek tartja, mégis több esetben életjáradéki szerződések a tartási szerződések átalakítása miatt jöttek létre, mindezek nem egyeztethetőek össze a 3:167. § (2) bekezdésében írtakkal, ami alapján azt a következtetést lehet levonni, hogy az (örökhagyó) tag számára gyakorlatilag mindegy, kitől kapja meg az üzletrész értékét.

A társaság számára nem közömbös, kik a tagok, ezért ha a társasági szerződés az üzletrész kívülálló személyre történő átruházását a társaság beleegyezéséhez köti, a beleegyezés megadásáról a taggyülés dönt. Ha a társaság az átruházási szándék bejelentésétől számított harminc napon belül nem nyilatkozik, a beleegyezést megadottnak kell tekinteni. Semmis a társasági szerződés azon rendelkezése, amely ennél hosszabb határidőt biztosít. ${ }^{861}$ A semmisségi klauzula tehát kijelöli az eltérés lehetőségének irányát: az átruházási szándék bejelentésétől számított harminc napnál hosszabb határidőt nem határozhat meg a társasági szerződés, a contrario rövidebbet igen. A taggyűlés összehívására, illetve magára a taggyülésre vonatkozó szabályok figyelembe vételével nem célszerü a rövidebb határidő meghatározása, hiszen adott esetben valamely (akár nagyobb szavazati joggal rendelkező) tag érdekét sértheti az, ha a taggyülés ugyan a társasági szerződésnek, de nem neki megfelelően került összehívásra, akkor is, hogyha a társasági szerződést aláírta, vagy legalábbis az abban foglalt rendelkezéseket magára nézve kötelezőnek ismerte el.

\footnotetext{
859 Jójárt 22.

${ }^{860}$ BH 1996. 534., BH 2000. 105., BH 2002. 14. idézi Jójárt 24.

${ }^{861}$ Ptk. 3:167. § (6) bek.
} 
E bekezdés alkalmazásában nem a társaságnak a másokat megelőző szerzési jogáról van szó, mint a (2) bekezdésben, hanem arról, amikor az átruházás érvényességéhez a taggyülés külön jóváhagyása is szükséges. Az átruházás társasági engedélyhez kötését a társasági szerződésben rögzíteni kell, az a létesítő okirat szükséges tartalmi kellékévé válik. ${ }^{862} \mathrm{~A}$ megváltozott kötelmi jogi szabályozásra tekintettel már nem vehető figyelembe az a döntés, miszerint ha a társasági szerződés az üzletrész kívülállóra történő átruházását a társaság beleegyezéséhez köti, e beleegyezés hiányában a kívülállóval kötött üzletrész átruházási megállapodás létre nem jött szerződésnek minősül. ${ }^{863}$

Ha a társasági szerződés az adásvételen kívüli jogcímen üzletrész-átruházáshoz a taggyülés hozzájárulását követeli meg, de a hozzájárulás megadásának vagy megtagadásának feltételeit nem határozza meg, nem lehet a társasági szerződésnek ezen rendelkezését nem létezőnek tekinteni. Ha a taggyülés hozzájárulása szükséges, az ügyvezető mindaddig nem köteles a tagváltozás átvezetésére, és az ezzel összefüggő változás-bejelentési kötelezettség teljesítésére, amíg a taggyülési hozzájárulás hiányzik. ${ }^{864}$ A döntés alapjául szolgáló konkrét esetben a megadás, illetve a megtagadás feltételei nem voltak meghatározva a társasági szerződésben, csak annyit tartalmazott, hogy a taggyülés hozzájárulásához köti az adásvételen kívüli átruházást. Az eljáró bíróság megállapítása szerint az ilyen rendelkezések társasági szerződésbe való beépítése a tagi érdekeknek a védelmét szolgálják, de ezek meghatározása nem valósulhat meg teljes részletességgel, nem lehet minden esetre kiterjedően szabályozni a kérdéskört. Folytatva ezt a gondolatmenetet, vélhetőleg ezért hagyta el a Ptk. 3:167. § (6) bekezdése az üzletrész átruházás beleegyezéshez kötésének szabályából a feltételrendszer társasági szerződésbeni rögzítésének kötelezettségét. Ha kiderül a szerződésből, hogy a felek akarata erre irányul, az ilyen kikötést a bíróságnak tiszteletben kell tartani, ${ }^{865}$ ezért még inkább igaz lesz az, hogy az üzletrész kívülálló részére történő átruházásához a taggyülés a hozzájárulást - a társasági szerződés részletes szabályozása hiányában is - megtagadhatja, amennyiben a határozatot megalapozó indokok a jegyzőkönyvből megállapíthatóak, ellenőrizhetőek. ${ }^{866}$

\footnotetext{
862 Pázmándi 2014b. 620.

863 ÍH 2010. 37.

864 ÍH 2014. 78.

865 ÍH 2014. 78.

866 ÍH 2015. 155.
} 
Lehetőség van arra, hogy a tagok a társasági szerződésben az üzletrész kívülálló

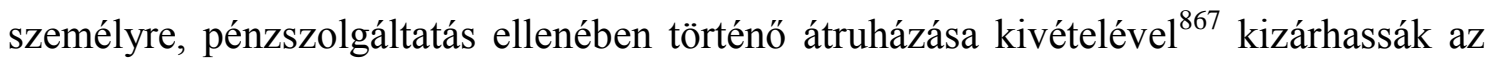
átruházást. A Gt. 126. § (2) bekezdése akképp rendelkezett, hogy az adásvételi szerződésen kívüli jogcímen történő átruházás a társasági szerződésben korlátozható vagy kizárható. A Ptk. erről külön explicite nem rendelkezik, mert a 3:4. §-ban rögzített diszpozitivitási teszt alapján a tagok értelemszerüen rendelkezhetnek így. A törvény csak azt nem teszi lehetővé, hogy a tagok a pénzszolgáltatás ellenében történő átruházást érvényesen kizárják, amiből az is következik, hogy korlátozhatják vagy feltételekhez is köthetik. ${ }^{868}$ Továbbra is igaz a bírói gyakorlatban megfogalmazásra került tétel, miszerint a társasági szerződésben a tagok az üzletrész kívülálló személyre történő átruházását a társaság beleegyezéséhez köthetik, illetve az adásvételi szerződésen kívüli jogcímen történő átruházást kizárhatják vagy korlátozhatják. Amennyiben a tagok a társasági szerződésben erről nem rendelkeztek, úgy csere vagy ajándékozás esetén az elővásárlási joggal a többi tag nem élhet, és az átruházás ilyen módon nem akadályozható meg. ${ }^{869}$ A cseréhez és az ajándékozáshoz hasonlóan, amelyek szintén átruházási jogcímnek minősülnek, az elővásárlási jog annak fogalmi kizártsága miatt sem érvényesülhet az öröklési szerződésnél.

Amennyiben az öröklési szerződésre nézve kizárták az átruházást, nem lesz érvényes az a szerződés, amely a tilalom ellenére rendelkezik az üzletrész sorsáról is, azt viszont nem tilthatja meg a társaság, hogy a tag a végrendeletében meghatározott személynek juttassa az üzletrészt. Éppen ezért megvalósulhat az is, hogy a társasági szerződés ilyen tartalmú rendelkezése esetén az üzletrészen kívül más, meghatározott vagyontárgyakat, vagy azon kívüli teljes vagyonára köt öröklési szerződést. Ha a társasági szerződésben meghatározásra került olyan személy, aki öröklés esetén az üzletrész megváltására jogosult, az ő döntésén múlik, hogy az örökös taggá fog-e válni vagy sem. Ugyanakkor figyelembe kell venni azt is, hogy az öröklési szerződésen alapuló öröklés is - nevéből is eredően - öröklés, azaz erre az esetre is fennáll a megváltás lehetősége, de az üzletrész forgalmi értékét az örökös meg kell, hogy kapja, nem marad ellenszolgáltatás nélkül az általa az örökhagyónak, annak életében nyújtott tartás vagy életjáradék. Ha a társasági szerződés kizárja vagy korlátozza akár az öröklési szerződés révén történő átruházást, még mindig dönthetnek úgy a tagok, hogy a

\footnotetext{
${ }^{867}$ Ptk. 3:167. § (7) bek.

${ }^{868}$ Komáromi - Pázmándi 211.; Tökey [27]

${ }^{869}$ ÍH 2004. 72.
} 
társasági szerződést megfelelö többséggel módosítják, és szabadon lehetővé teszik, vagy ha korlátozták, illetve ha korábban teljesen kizárták, akkor más feltételhez kötik azt. ${ }^{870}$

Az üzletrész-átruházás a társaság tagja (öröklési szerződés esetén az örökhagyó) és az üzletrész megszerzője (a szerződéses örökös) közötti szerződés, amely kötelező alakisághoz kötött. ${ }^{871}$ Bármelyik átruházási jogcímen kerül sor az üzletrész átruházására, azt írásba kell foglalni. A közkereseti és a betéti társasághoz képest viszont az üzletrész átruházása a társasági szerződés módosítását nem igényli. ${ }^{872}$ Mégis hasonlóan az említett társaságokhoz, itt sem fog gondot okozni a formakövetelmény az öröklési szerződések esetén, hiszen a szerződésre vonatkozó alaki követelmények túl is mutatnak az egyébként elvárt egyszerü írásbeliségen. ${ }^{873}$

Főszabály szerint $^{874}$ a jogosultak személyének megváltozását és annak időpontját a tagjegyzékbe való bejegyzés céljából az üzletrész megszerzője a szerzéstől számított nyolc napon belül köteles bejelenteni a társaságnak. (Praktikusan, miután a társaság képviselője az ügyvezetője, így neki kell bejelenteni.) ${ }^{875}$ A bejelentést közokiratban vagy teljes bizonyító erejü magánokiratban kell megtenni, és mellékelni kell hozzá az üzletrész-átruházási szerződést. A bejelentésben nyilatkozni kell a megszerzés tényén kívül arról is, hogy az üzletrész megszerzője a társasági szerződés rendelkezéseit magára nézve kötelezőnek ismeri el. Mindezek szintén eltérnek öröklési szerződés esetén, újra figyelemmel arra, hogy de iure és de facto az örökös csak az örökhagyó halálával szerzi meg az öröklési szerződésben meghatározott üzletrészt. Így ez a nyolcnapos határidő itt nem lesz irányadó, mivel öröklés esetén nem tartalmaz annak bejelentésének határidejére irányadó szabályt. Az örökös érdeke a mihamarabbi bejelentés a tagsági jogok gyakorlása miatt. A Ptk. 3:169. §-ban megfogalmazott, az üzletrész átruházásához kapcsolódó joghatásokat is némileg eltéríti az öröklési szerződés. Az általános szabály szerint az üzletrész átruházása esetén az átruházónak a tagsági jogviszonyból eredő jogai és kötelezettségei az üzletrész megszerzőjére szállnak át, ${ }^{876}$ amely ugyanúgy öröklési szerződés esetén is igaz lesz, a különbség újfent csak annak időpontjában jelentkezik. Megkötésekkel alkalmazhatóak a (2) bekezdésben

\footnotetext{
${ }^{870}$ Az üzletrészek átruházásának Ptk. 3:166-167. §-ban foglaltakon kívüli eseteinek feldolgozásához nagy segítséget nyújtott Papp Tekla professzor asszony 2015. április 17-én, a Szegedi Tudományegyetemen tartott Társasági jog II. előadása.

${ }^{871}$ BDT 2016. 3551.

${ }^{872}$ Ptk. 3:168. § (1) bek., PJD 2016. 5.

${ }^{873}$ Vö. Kisfaludi 2014b. 381.

${ }^{874}$ Ptk. 3:168. § (2) bek.

${ }^{875}$ Ptk. 3:29. § (1) bek., Kisfaludi 2014b. 381.

${ }^{876}$ Ptk. 3:169. § (1) bek.
} 
foglaltak is, miszerint az üzletrész átruházása folytán bekövetkezett tagváltozás a társasággal szemben annak bejelentésétől hatályos; az üzletrész új jogosultját a társasággal szemben a nyilvántartásba vételtől függetlenül a bejelentéstől illetik meg a tagsági jogviszonyból eredő jogosultságok, és terhelik a tagsággal járó kötelezettségek. Az örökösnek is be kell jelentenie az öröklést, de az örökhagyó tagnak érdemes még magát az öröklési szerződés megkötését is a többi tag tudtára adni, amikor azt megkötötték, hogy a tagok „felkészülhessenek” az örökhagyó halála esetére. Ugyanakkor ennek az átruházó szerződésnek nem ugyanazok lesznek a joghatásai, mint a többi átruházási jogcímnek, hiszen az örökös még mindig az örökhagyó halálát követően - amennyiben a szerződéses örökös valóban túl is fogja élni az örökhagyót, és más ok miatt sem esik ki az öröklésből - szerezheti meg az üzletrészt, így kell figyelembe venni a bejelentés hatályosságát is.

Megjegyzendő, hogy az üzletrészek vonatkozásában a Ptk. által bevezetett pénzszolgáltatás ellenében történő átruházás kategorizálása nem problémamentes: az üzletrészről el lehet mondani, hogy vagyoni értékkel bír, immateriális jogok és kötelezettségek összessége, amely a Ptk. hatályba lépéséig a törvényi szabályozás és a bírói gyakorlat alapján a hasznosítás és a rendelkezés során egyértelmüen dolog módjára viselkedett, és amely inkorporálta a törzsbetét mellett a tagsági jogokat és kötelezettségeket is. Az üzletrésszel való rendelkezés során az üzletrész által megteremtett egység nem bontható fel akképp, hogy például egyes jogokat a több jogosult között felosztanának, ez a felosztás legfeljebb csak eszmei hányadok szerint valósulhat meg. ${ }^{877}$ A Ptk. dolog fogalma ${ }^{878}$ alá aggály nélkül nem sorolható, az esetleg releváns értékpapírnak sem lehet minősíteni. ${ }^{879}$ Az üzletrészek jogátruházással ${ }^{880}$ nem ruházhatóak át, mert nem tisztán jogokból áll, a szerződésátruházás azért nem jöhet szóba, mert nem szerződéses pozícióról van szó, kétségtelen, hogy a társaság létrejöttéhez szükség van társasági szerződésre, és a társaság müködését alapvetően befolyásolja a társasági szerződés, de a cégbejegyzést követően egyértelmüen nem csupán szerződéses felek, hanem egy önálló jogi entitás tagjairól lehet beszélni. A dolog adásvételére irányuló szerződés szabályait megfelelően alkalmazni kell az olyan szerződésre, amelyből jog vagy követelés visszterhes átruházására vonatkozó

\footnotetext{
${ }^{877}$ Barta 2016b. 163.

${ }^{878}$ Ptk. 5:14. §

${ }^{879}$ Vö. Ptk. 3:11. §

${ }^{880}$ Ptk. 6:202. §
} 
kötelezettség fakad, ${ }^{881}$ de miután az üzletrész nem jog vagy követelés, hanem jogok és kötelezettségek összessége, így ez alapján az üzletrész nem lehet adásvételi szerződés tárgya sem. A Ptk. értelmező rendelkezése ${ }^{882}$ alapján nem is vagyontárgy, ugyanis az előbb kifejtettek alapján nem dolog, nem jog és nem is követelés, mindezekre tekintettel alkotta meg a kódex ezt a különös kifejezést az üzletrészek átruházására. Célszerü lett volna valamelyik kategória alá besorolni az aggálymentes elbírálás érdekében. Az üzletrész kívülálló személyre történő átruházásának szabálya között mondja ki a jogalkotó, ${ }^{883}$ hogy az üzletrész megszerzése során meghatározott személyek az elővásárlási jogra vonatkozó rendelkezések megfelelő alkalmazásával másokat megelőzően jogosultak. Ez alapján lehet arra a következtetésre jutni, hogy valamilyen adásvételi szerződéssel lehetséges az átruházás mert az elővásárlás egyértelműen az adásvételi szerződés egyik különös neme. További átruházási jogcím lehet a csere, ajándékozás, apportálás, tartás, életjáradéki szerződés, halál esetére szóló ajándékozás, illetve az öröklési szerződés, amelyek ugyan nem illeszthetőek össze maradéktalanul a tárgyalt szabályozással, de a korábbi jogi helyzethez hasonlóan megfelelnek átruházási jogcímként. $^{884}$

\subsubsection{Részvénytársaságok}

A tulajdon-átruházás kétféle jogügyletből áll: a tulajdonjog átruházására vonatkozó kötelezettségvállalásból, mint jogcímet teremtő kötelező ügyletből (szerződés) és a tulajdon-átszállást eredményező átruházó (rendelkező) ügyletből. Ez a kettősség áll a részvény-átruházásra is, vagyis különbséget kell tenni a jogcímes jogügylet (legtöbbször szerződés) érvényes létrejötte és a tulajdonátszállást eredményező forgatmány között. ${ }^{885}$ „A részvény értékpapír, és mint ilyen, szabadon átruházható. Az átruházás korlátozása éppen ezért ritkán fordul elő, pontosabban szólva, a korlátozás esetei olyanok, hogy azok valóban kivételt jelentenek az általános

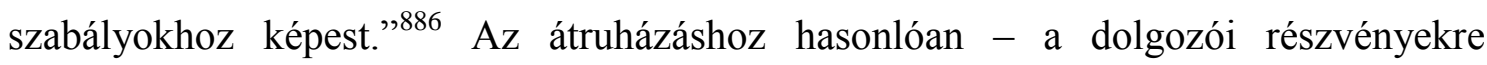

\footnotetext{
${ }^{881}$ Ptk. 6:215. $\S(3)$ bek.

${ }^{882}$ Ptk. 8:1. $\S(1)$ bek. 5. pont

${ }^{883}$ Ptk. 3:167. $\S(2)$ bek.

${ }^{884}$ Papp Tekla professzor asszony a Szegedi Tudományegyetem Állam- és Jogtudományi Karán 2015. március 27-én elhangzott Társasági jog II. előadása alapján. A Ptk. által használt jogcímmel kapcsolatos problémára hívja fel a figyelmet Barta Judit is. Lásd Barta 2016b. 165.

${ }^{885}$ Török T. 2011.9.

${ }^{886}$ Sándor T. 2014b. 272.
} 
vonatkozó szabályozás ${ }^{887}$ kivételével - a részvények halál esetén is forgalomképesek, azzal kapcsolatosan nem merülnek fel a korábbiakhoz hasonló problémák.

Lehetőség van arra, hogy a részvénytársaság a részvény átruházását az alapszabályban korlátozza, vagy az átruházást a társaság beleegyezéséhez kösse, de ezek a korlátozások harmadik személyekkel szemben csak akkor hatályosak, ha a korlátozás és annak pontos tartalma a részvényből, illetve dematerializált részvény esetén az értékpapírszámla adataiból kitűnik. ${ }^{888}$ „Ez az előírás egybevág az általános értékpapírjogi szabályozás alapelveivel, amelyek szerint egy értékpapírból eredő jogokkal szemben csak olyan kifogás hozható fel, amely magából az értékpapírból kitűnik." ${ }^{889} \mathrm{Ha}$ az átruházás korlátozására kerül sor, akkor az a részvénytársaság személyegyesítő jellegének megjelenését idézi elő. A Ptk. nem korlátozza ezt csak a zrt.-re, a nyrt.-k is megtehetik ugyanezt az alapszabályukban, ők azonban valószínüleg nem gyakran fogják a korlátozási lehetőséget alkalmazni, mert akkor az a tőzsdei kereskedést, mint a nyilvánosan müködő részvénytársaságok egyik legjelentősebb jellemzőjét, gátolná. 890

„Fontos rámutatni, hogy ezek a korlátozások kizárólag az átruházás útján történő részvényszerzést korlátozzák, az átruházásnak nem minősülő módon, pl. öröklés, jogutódlás útján történő részvényszerzés nem korlátozható. ${ }^{„ 891}$ Az öröklési szerződés már említett sajátos vonása megjelenik e társasági formánál is. Ez a jogügylet átruházásnak minősül, amire vonatkozóan korlátozás - a korlátolt felelősségü társaságokhoz hasonlóan - sor kerülhet a részvénytársaság alapszabályában is, de nem zárható ki és nem is korlátozható törvényes és más végintézkedés útján a részvények örökösre történő átszállása. Ha kizárták, vagy korlátozták az átruházást öröklési szerződés útján, és a korlátozásnak nem felel meg az adott szituáció, akkor az öröklési szerződés tartalmi szempontból érvénytelen, de ha az alakiság vonatkozásában megfelelö, akkor, mint végrendelet, megállhatja a helyét, a jogutódlás bekövetkezhet ezúton, ezt tehát nem tudja korlátozni az alapszabály.

A korábbi szabályozáshoz képest a Ptk. ugyan már nem emeli ki, de továbbra is igaz lesz az, hogy az alapszabály vagy szerződés korlátozása, illetve a társaság beleegyezésén túlmenően jogszabály is gátolhatja a részvények megszerzését. A

\footnotetext{
${ }^{887}$ Ptk. 3:234. § (2)-(4) bek.

${ }^{888}$ Ptk. 3:219. § (1) bek.

${ }^{889}$ Kisfaludi 2014b. 430-431.

${ }^{890}$ Kisfaludi 2014b. 431.

${ }^{891}$ Vezekényi 728.
} 
törvénykönyv nem határozza meg, hogy az alapszabály a részvény átruházását hogyan, mi módon korlátozza. Ilyen korlátozásnak minősül például az, ha meghatározzák az egy személy által maximálisan megszerezhető részvények mennyiségét, ha ezt a korlátozást tartalmazza az alapszabály, akkor azt pontosan, azaz részvényfajták és részvényosztályok szerint külön-külön kell megtenni annak érdekében, hogy a részvényesek és harmadik személyek is pontos képet kaphassanak az általánostól eltérő szabályokról. „Fontos rámutatni, hogy ezek a korlátozások kizárólag az átruházás útján történő részvényszerzést korlátozzák, az átruházásnak nem minősülő módon, pl. öröklés, jogutódlás útján történő részvényszerzés nem korlátozható.” ${ }^{892}$ Az öröklési szerződés már említett sajátos vonása megjelenik e társasági formánál is. Ez a jogügylet átruházásnak minősül, amire vonatkozóan korlátozásra - a korlátolt felelősségü társaságokhoz hasonlóan - sor kerülhet a részvénytársaság alapszabályában is. Nem zárható ki és nem is korlátozható törvényes és végintézkedés öröklés útján a részvények örökösre történő átszállása. Ha kizárták, vagy korlátozták az átruházást öröklési szerződés útján, és a korlátozásnak nem felel meg az adott szituáció, akkor az öröklési szerződés tartalmi szempontból érvénytelen, de ha az alakiság vonatkozásában megfelelö, akkor, mint végrendelet, megállja a helyét, a jogutódlás bekövetkezhet ezúton, ezt tehát nem tudja korlátozni az alapszabály. Érdemes megjegyezni, amennyiben a korlátozás pontos tartalma az alapszabályban meghatározásra került, és a részvényből (értékpapírszámla adataiból) is kiderül, akkor az egy személy által megszerezhető részvények darabszámának korlátozása öröklés esetén is fennáll, ha nincs jogcímbeli különbség példának okáért az adásvételhez képest. A törvényes örökös vagy az öröklési szerződéstől eltérő végintézkedés útján örökössé váló személy is megszerzi a részvényt az ipso iure öröklés folytán, azonban a társasági jogi korlátozás miatt intézkedni kell. Egy ilyen korlát túllépése esetén az alábbi lehetőségek adódnak: más részvényfajtává vagy más részvényosztályba tartozó részvénnyé alakítják át a korlátozással érintett részvényeket, amelyek már nem állhatnak egy személy tulajdonában; az alapszabályt módosítják, és a korlátozást eltörlik vagy felemelik, hogy még az újonnan szerzett részvények ebbe a határba beleférjenek; vagy a részvényessé vált örökös értékesíti a részvényeket.

A korlátolt felelősségü társaságokhoz hasonlóan lehetőség van a részvények átruházásához a társaság beleegyezésére. Ha a részvénytársaság alapszabálya a

${ }^{892}$ Vezekényi 728. 
részvények átruházásához a részvénytársaság beleegyezését írja elő, ${ }^{893} \mathrm{az}$ alapszabályban meg kell határozni azokat az okokat is, amelyek a beleegyezés megtagadásához vezethetnek. A beleegyezésről való döntés az igazgatóság hatáskörébe tartozik. $^{894}$

Eltérő a két társaság között, hogy a részvénytársaságnál meg kell határozni a megtagadáshoz vezető lehetséges okokat, de itt is irányadó lehet az a bírósági döntés, ${ }^{895}$ miszerint ha ezek nem is lennének meghatározva, az eljáró bíróságnak akkor is figyelembe kell venni a részvényesek ebbéli kívánságát. Ez a szabály garanciális jellegü, mert fő szabály szerint az igazgatóság, tehát nem a közgyülés hatáskörébe tartozó kérdésről van szó. Nem elképzelhetetlen az az eset, hogy pl. egy kisebb részvényesi létszámú zrt.-nél, ahol az igazgatóság tagjai nem részvényesek, megtagadják olyan személyek részvényszerzését, akikkel kapcsolatban egyébként egyik részvényesnek sem lenne kifogása, akár haszonra is szert tehetnének. A közgyülés határozhatja meg azokat az okokat, amik alapján egyértelmüen meg kell tagadni ezen okok alá eső személyek részvényszerzését. Az igazgatóság - azért, hogy ne kelljen minden részvényátruházáskor a közgyülésnek összeülnie - megvizsgálja, hogy a közgyülés által meghatározott kritériumok érvényesülnek-e az adott személy vonatkozásában. Ha ezen személyek belépését alapos ok nélkül, akár az alapszabályban meghatározott okok fenn nem állása esetén megtagadnák, akkor külön eljárást kellene indítani az igazgatósággal szemben, mert olyan döntést hoztak, ami az általuk képviselt társaság érdekeivel ellentétes, e helyzetben komoly bizonyítási kérdéseket kellene megválaszolni, ezért kell meghatározni pontosan az okokat. Ugyancsak a sajátos 3:4. §beli szabályozási módszer miatt más szerv hatáskörébe is tartozhat a beleegyezés megadása, amit erre figyelemmel meg kell határozni az alapszabályban.

A Gt. 205. § (3) bekezdésbeli szabályozáshoz képest még példálózó jelleggel sem sorol fel lehetséges megtagadási okokat, de továbbra is igaz az, pl. ha versenytárs szeretné megszerezni a részvényeket (hostile take over), ${ }^{896}$ meg lehet tagadni a részvény átruházását, mert a megszerzett információkat saját maga hasznára használja fel, a részvényekkel együtt járó döntési jogát nem a társaság, hanem a tag, mint versenytárs

\footnotetext{
${ }^{893}$ Ptk. 3:250. § (2) Az alapítók érvényesen az alapszabályban rendelkezhetnek: d) a részvények átruházásának korlátozásáról vagy annak a részvénytársaság beleegyezéséhez kötéséről; ${ }^{894}$ Ptk. 3:220. § (1) bek., ÍH 2009. 30.$$
895 \text { ÍH 2014. } 78 .
$$$$
{ }^{896} \text { Sándor T. 2014b. 272., Harsányi 2016b. } 211 .
$$ 
érdekét fogja szolgálni. ${ }^{897}$ Természetesen ezek a lehetőségek öröklési szerződés útján való átruházás esetén is bekövetkezhetnek, éppen ezért az alapszabály megfogalmazásakor, esetleges módosításakor ezeket a tényezőket is figyelembe venni.

Nem kizárt az, hogy csak egyes részvényfajták vagy részvényosztályok tekintetében korlátozza az alapszabály az átruházást a társaság beleegyezésével, ugyanakkor ebben az esetben is elengedhetetlen a pontos megfogalmazás. Akár a társaság, akár az igazgatóság vagy bármely másik szerv részéről elvárt a beleegyezés, mindegyikre igaz az, hogy a Ptk. „megtagadáshoz vezethetnek” kitétele azt jelenti, hogy a beleegyezést nem feltétlen kell megtagadnia, de határozhat úgy az alapszabály, kategorikus rendelkezések formájában, hogy meghatározott tényállás bekövetkezése esetén mindenféleképp meg kell tagadni a beleegyezést. ${ }^{898}$ Természetesen itt is igaz az, hogy ezek a rendelkezések nincsenek „kőbe vésve”, lehetőség van ezeknek a későbbi módosítására. Ha az igazgatóság (illetve a beleegyezés megadására jogosult szerv) a részvényre vonatkozó átruházási szándék bejelentésétől számított harminc napon belül nem nyilatkozik, a beleegyezés megadottnak tekintendő, ${ }^{899}$ azaz a kft.-hez hasonlóan „a hallgatás beleegyezés".

A korlátozottan forgalomképes dolgozói részvény öröklésén túlmenően az átruházásukra vonatkozóan is vannak speciális szabályok, amelyeket az öröklési szerződések vonatkozásában is figyelembe kell venni: a dolgozói részvény érvényesen a részvénytársaság munkavállalóira és azokra ruházható át, akik számára az alapszabály ezt a jogot a részvénytársasággal fennállt korábbi munkaviszonyukra tekintettel biztosítja. $^{900} \mathrm{Az}$ említett forgalomképesség korlátozását jelenti ez a szabály, mert már önmagában a részvény megszerzésére jogosult személyi kört is megszabja, öröklési szerződéssel eleve csak olyan személyekre ruházható át a dolgozói részvény, akik megfelelnek a fenti feltételeknek.

Összegzésképpen megjegyezhető, hogy a társasági részesedés forgalomképességét akár ki is lehet zárni, de a forgalomképtelenség ellenére, a tagsági jogokon túlmenően, olyan vagyoni jogot is megtestesít mind az üzletrész, mind a részvény, amikre ha az örökös nem tarthatna igényt, akár, ha másképp nem is, megváltási igényként, akkor sérülne az ipso iure öröklési rend. Ezért kell a korlátolt felelősségü társaságnál a társaság, valamely tag, vagy a társasági szerződés által kijelölt

\footnotetext{
${ }^{897}$ Kisfaludi 2014b. 431.

${ }^{898}$ Vezekényi 730.

${ }^{899}$ Ptk. 3:220. § (2) bek.

${ }^{900}$ Ptk. 3:237. § (1) bek.
} 
harmadik személy magához váltása esetére az örökös részére az üzletrész forgalmi értékét kifizetni. Hasonló szabály nem került megfogalmazásra a részvénytársaságnál, de miután egy alapszabálybeli rendelkezés csak a részvény átruházását zárhatja ki, magát az ipso iure öröklést nem lehet ekképp befolyásolni. A hagyatékból ilyen módon nem vonható ki vagyon.

\subsection{Az osztrák öröklési szerződés}

Az osztrák jog alapján az öröklési szerződés házassági szerződésnek minősül, ${ }^{901}$ ami a végrendeletekkel ellentétben egyoldalúan nem vonható vissza, közös megegyezéssel szüntethető meg, olyan jogügylet az örökhagyó és az örökös között, amivel a megállapodás szerint az örököst felhívják öröklésre, amennyiben túléli az örökhagyót. ${ }^{902}$

Az öröklési szerződés jogintézményének vonatkozásában a magyar és az osztrák jog között lényeges eltérés tapasztalható. A magyar jog minimális alanyi korlátozásán túlmenően (nem tehet minden személy az általa megkívánt formában végrendeletet) bárki szabadon köthet egymással ilyen szerződést, az osztrák jog ehhez képest csak a házastársak számára engedélyezi ezt, ${ }^{903}$ amin nem változtat a 2017. január 1-jén hatályba lépett öröklési jogi novella sem. Örökös lehet akár az egyik házastárs, kölcsönösen is megnevezhetik egymást örökösnek, harmadik személyt azonban nem jelölhetnek meg. Az osztrák szabályozás fényében elismerhető az a gondolat, hogy helytelen akképp rendelkezni az öröklési szerződésben, hogy harmadik személyt jelölnek meg örökösként, hiszen léteznek harmadik személy javára szóló szerződések, de maga a törvénykönyv erre lehetőséget adna, ${ }^{904}$ és nem fogalmazna egyértelmüen, hogy ilyen szerződés csak házastársak között köthető. Harmadik személy örökössé nevezése a magyar jogban sem lehetséges, a leendő örökhagyó és örököse között kell a szerződést megkötni.

Az osztrák öröklési szerződésről is megjegyezhető, hogy a szerződések és a végrendeletek között helyezkedik el, mint a magyar jogban, mindkettő jellegzetességeivel rendelkezik. ${ }^{905}$ A kontraktus alakszerüségét tekintve a magyar

\footnotetext{
901 ABGB 1217. §

902 Apathy 127.

903 ABGB 1249. §

${ }^{904}$ Welser 522.

${ }^{905}$ Welser 522., Apathy 128.
} 
szabályozással rokonítható vonás, hogy a közjegyzői okiratoknak és az írásbeli végrendeleteknek kell megfelelniük az érvényesség érdekében, ${ }^{906}$ míg a tartalmát tekintve alapvetően a végrendeletekre irányadó anyagi feltételeknek kell eleget tenni. ${ }^{907}$ Ez utóbbit vizsgálva nem kapunk olyan „instrukciót”, miszerint az örökössé nevezés fejében tartás vagy életjáradék lenne az ellenszolgáltatás, nem tartalmi elem. Tartási szerződés megkötésére a magyar szabályozásnak megfelelő tartalommal ugyan lehetőség van, de azt alapvetően családjogi alapokon kívánják megoldani, a német nyelvü területek közül csak Svájcban nevesítettek nem családjogi alapokon nyugvó, az életjáradéki szerződéssel rokonítható tartást „Verpfründung” elnevezéssel; a magyar tartási szerződéshez hasonló jogintézményt se a német, se az osztrák jog nem ismer. ${ }^{908}$ Hasonló a magyar joghoz az osztrák „Ausgedinge”, amit a gyakorlat és a hagyomány ismer, tipikusan a vidéki parasztság körében terjedt el, mert fő célja a paraszti vagyon megőrzése, egyben tartása, ekkénti átörökítése volt. Ezért és a tartási jelleg okán sem volt lehetőség az „Ausgedingére” jellemző személyes jelleg feloldására. ${ }^{909}$ Az osztrák jog ismeri az életjáradéki szerződést, és arra, mint szerencseelemet tartalmazó szerződésre tekint. ${ }^{910}$

Az osztrák irodalomban is megjelent az az álláspont, miszerint az üzletrészek átruházása folyamán életjáradék is lehet az ellenszolgáltatás, amit érdemes és lehetséges is akképp kombinálni, hogy az életjáradéki szerződés megkötésekor (vagy egy meghatározott, de a szerződéskötéstől számítva nem hosszabb időn belül) nyújtandó fix összegből és a tulajdonképpeni, időközönként rendszeresen visszatérő életjáradékból álljon. ${ }^{911}$ Ugyanakkor az előbbiekkel egyezően ez nem képezi az öröklési szerződésbeli kötelezettség teljesítését, mint az életjáradék megfizetése, de a magyar jogba minden aggály nélkül átültethető az életjáradék meghatározásának módja.

Mindezek alapján megállapíthatjuk, hogy a magyar és az osztrák öröklési szerződés nem ugyanaz a jogintézmény, éppen emiatt az ABGB-beli öröklési szerződés nem alkalmazható ugyanolyan körülmények között az osztrák társasági jogban halál esetére irányadó utódlási lehetőségként, mint a magyar öröklési szerződés.

\footnotetext{
${ }^{906}$ ABGB 1249. §

${ }^{907}$ Welser 523.

908 Jójárt 19., Uo. 23.

909 Jójárt 29.

910 Jójárt 26., ABGB 1284-1286. §

${ }^{911}$ Kalss - Probst 714.
} 


\section{A hagyatéki tartozásokért való felelősség társasági jogi kitekintéssel}

\subsection{Bevezetés}

A fejezet a hagyatéki tartozásokért való helytállás alapjait kívánja bemutatni, kitekintéssel a régi Ptk. eltérő szabályaira, melyek között az öröklési jog több jelentős koncepcióváltásával (például a túlélő házastárs öröklési jogi helyzete) ellentétben, ebben a témakörben hasonló fajsúlyú módosítást nem lehet találni.

A vizsgálat aktualitását adja az, hogy az utóbbi években megnövekedett azon hagyatéki eljárások száma, ahol a magas hagyatéki tartozások miatt megfontolandó kérdés az örökösök számára, hogy igényt tartsanak-e az örökségre, vagy inkább azt visszautasítsák. ${ }^{912}$ Korábban ugyanis a temetési költségek, a hagyatéki költségek és a hagyatéki eljárás költségei jelentették a hagyatéki terhek nagyobb részét, és csak kisebb részben az örökhagyó tartozásai. Mára ez az arány megfordult. ${ }^{913}$ „Túlterhelt hagyatéknak azt tekintjük, amikor a hagyatéki terhek meghaladják a hagyatéki vagyon értékét." 914

További cél annak bemutatása, hogy a fent körülírt témakörnek szoros kapcsolata van a társasági joggal: fokozatosan jelennek meg olyan hagyatéki eljárások, amelyekben az örökhagyó hagyatékához társasági jogi részesedés tartozik.

A következőkben a jogszabályi környezet bemutatásával együtt a főbb jogtudományi meglátásokat ismertetjük a témához szervesen kapcsolódó joggyakorlattal, kiegészítve saját meglátásainkkal.

\subsection{A hagyatéki tartozások}

Az örökléssel az a sajátos eset áll elő, hogy a vagyoni kötelezettségek teljes egészében átszállnak ugyan, ettől azonban elválik a kötelezettségekért való felelősség terjedelme. Ezért nevezzük hagyatéknak az örökhagyót a halálakor megillető

\footnotetext{
912 Visegrádi 424.

913 Uo.

914 Bókai 7.
} 
valamennyi vagyoni jellegü jogot és kötelezettséget, míg örökségnek csak azt, amely ebből az örökösre „mint egész” (jogok a kötelezettségekkel együtt) átszáll. ${ }^{915}$

A Ptk. taxatíve felsorolja a hagyatéki tartozásokat; ezek megegyeznek a régi Ptk.-ban foglaltakkal: ${ }^{916}$

a) az örökhagyó illő eltemetésének költségei;

b) a hagyaték megszerzésével, biztosításával és kezelésével járó szükséges költségek (hagyatéki költségek), valamint a hagyatéki eljárás költségei;

c) az örökhagyó tartozásai;

d) a kötelesrészen alapuló kötelezettségek;

e) a hagyományon és a meghagyáson alapuló kötelezettségek. ${ }^{917}$

Ez a felsorolás egyben kielégítési sorrend is, ami azt jelenti, hogy ,a meghatározott sorrendben előbb álló csoportba eső tartozások a kielégítés során megelőzik a hátrább álló csoportba soroltakat." "18 Abban a csoportban, amelyben valamennyi tartozás teljes kielégítésére nincs lehetőség, kielégítésnek a követelések arányában van helye.

A törvényi szabályozás alapján az egyes tartozásokat csoportosítani is lehet: az a)-b) pont alattiak az örökhagyó halála folytán merülnek fel, a c) pont alattiak az örökhagyó életében keletkezett, őt terhelő és halála miatt a jogutódjára átszálló tartozások, míg a d)-e) pontban nevesített tartozások az örököst terhelő tartozások. ${ }^{919}$

A fenti taxatív felsorolás azt jelenti, hogy csak azok a tartozások vehetők figyelembe, amelyek valamelyik nevesített tartozáscsoportba tartoznak. „Az egyes csoportokon belül már különböző jogcímeken felmerülö tartozások jelenhetnek meg, amelyek kapcsán vita merülhet fel, helye van-e annak, hogy azokat hagyatéki vagyonból kielégítendő követelésként ismerjük el. A régi Ptk. alapján kialakult és továbbra is irányadónak tekinthető joggyakorlat több vitás kérdésben letisztult." ${ }^{, 920}$ Ilyen vitás kérdésnek minősült például az örökhagyó tartozásai között az örökhagyó tartásával, gondozásával, ápolásával és gyógykezelésével felmerült költségek érvényesítése, melyet - az eset körülményei alapján - a Legfelsőbb Bíróság hagyatéki teherként ismert el. ${ }^{921,922}$

\footnotetext{
915 Anka 2014a. 17-18.

916 régi Ptk. 677. § (1) bek.

${ }^{917}$ Ptk. 7:94. § (1) bek.

918 Orosz 2014c. 309.

${ }^{919}$ Fabó 2014a. 739.; Complex CD jogtár 1959. évi IV. törvény 677. §-hoz füzött magyarázata

${ }^{920}$ Fabó 2014a. 739-740.

${ }^{921}$ BH 1993. 428., BH 1991. 20.
} 
A hagyatéki eljárásról szóló törvény értelmező rendelkezéseit tárgyaló 6 . § b) pont alapján a 7:94. § (1) bek. a)-b) pont alá sorolt követelések eljárásjogi szempontból hagyatékátadási tehernek minősülnek. A Hetv. ezzel tulajdonképpen megerősíti a Ptk.ban foglaltakat, de meg is kettőzi a jogszabályi rendelkezést.

Külön pont tartalmazza a hagyatéki hitelezö fogalmát, aki nem más, mint

- egyrészt a hagyatékátadási teher, valamint az örökhagyó tartozásainak megfizetése iránti igényét a hagyatéki eljárásban előterjesztő személy,

- másrészt az, aki a hagyatékhoz tartozó vagyontárgyra - az örökhagyónak a vagyontárgy reá történő átruházására vonatkozó kötelezettségét állítva - a hagyatéki eljárásban kötelmi jogcímen támaszt igényt.

Az anyagi jogi és az eljárásjogi szabály között látszólag ellentmondás van, mivel a hagyományost és a meghagyás jogosultját nem említi meg ez a pont, de a kiterjesztést a Hetv. 6. § (2) bekezdésében ${ }^{923}$ megtalálhatjuk. Észre kell venni azt, hogy a kiterjesztés nem teljes, mert a szöveg a dologi hagyományost nem nevezi meg. A két törvény közötti összhang érdekében - tekintettel arra is, hogy a régi Ptk. is ugyanígy rendelkezett - a jogalkotónak célszerü lett volna módosítania a Hetv. e §-át akképp, hogy a 6 . $\S(2)$ bekezdésében - vagy eleve az ea) pontban - további megszorítás nélkül nevesíti a hagyományost, valamint a meghagyás jogosultját. Az eljárási jogszabály általam vélt hiányossága ellenére a Ptk. alapján a dologi hagyományost is hagyatéki hitelezőnek kell tekinteni.

A hagyatéki tartozás rendszerint olyan harmadik személlyel szemben áll fenn, aki maga nem örökös. ${ }^{924}$ Sajátos elszámolási viszony jön létre abban az esetben, ha az örökös egyben hagyatéki hitelező is. Ez a tény a tartozás fennállásán és hagyatéki jellegén nem változtat, confusio valósul meg azon rész tekintetében, amelyet az örökös örökrészként megörökölt és a hagyatéki tartozás azon hányadában, ami őt, mint örököst terhelné. ${ }^{925}$ „A tétel kimondása egyértelművé teszi azt, hogy az örökhagyó, mint kötelezett és későbbi örököse, mint jogosult között keletkezett jogviszony nem szünik meg annak révén, hogy a kötelezett halálával tartozását ugyanaz örökli, mint akivel szemben az fennállt. Ezáltal az örökös vagyona két alvagyonra oszlik: a hagyatékra, az abból őt illető örökrészre az aktív és passzív elemekkel, utóbbiak között az örökös

\footnotetext{
922 Vékás - Weiss 2502.

923 Hetv. 6. § (2) bek.: A meghagyás és a kötelmi hagyomány jogosultjára a hagyatéki eljárásban a hagyatéki hitelezőre vonatkozó szabályokat kell alkalmazni.

924 Orosz 2014c. 308.

${ }^{925}$ Orosz 2014c. 308., Ptk. 7:94. § (2) bek.
} 
követelésével, másfelől a hagyaték megnyílása előtti magánvagyonára, benne az örökhagyóval szemben keletkezett követeléssel, amelyet az azt megillető rangsorban éppen úgy érvényesíthet, mint bármely más hagyatéki hitelező." 926

Egy irányadó bírói döntés alapján ${ }^{927}$ az örökösnek saját, a hagyatékkal szembeni követelésének terhét és ezeket a költségeket a rá eső hagyatéki érték arányában neki is viselni kell, mert a hagyatéki tartozás valamennyi örököst örökrészeik arányában terheli. A hagyatéki tartozásokért az örökösök felelössége egymás közti viszonyukban a hagyatékban való részesedés mértékéhez igazodik, s ezen nem változtat az sem, ha az egyik örököstárs egyben hagyatéki hitelező is.

A hagyatéki tartozások felsorolása olyan taxáció, ami a kielégítés sorrendjét is meghatározza. Az ettől való eltérés a szabályt megszegő örökös korlátozott felelősségét (Ptk. 7:96. §) szüntetheti meg, ha az eltérésnek a törvény által elismert alapja nem volt. $^{928,929}$

\subsubsection{Az örökhagyó illö eltemetésének költségei}

Az örökhagyó illő eltemetésének költségei általában, de nem minden esetben, a hagyatékot terhelik. Ha van más személy, aki valamely jogalapon a költségek viselésére kötelezhető, akkor a temetés költsége nem vehető figyelembe hagyatéki tartozásként. ${ }^{930}$ Így például büncselekmény következtében meghalt személy eltemettetésével és a gyászszertartással felmerült költség olyan kár, amelynek megtérítésére azt a személyt kell kötelezni, aki az örökhagyó halálát okozta. Az ilyen költségek viselésére tehát az örökös elsődlegesen nem kötelezhető, de vállalhatja. ${ }^{931}$ A költségek elismerése nem lehet parttalan, egyrészt csak az a költség ismerhető el, ami egyértelműen és kizárólag az örökhagyó eltemetésével függ össze, másrészt, amely az adott helyzetben megfelel az általános szokásoknak, illetve a kegyeleti szempontok indokolják. ${ }^{932}$ A bírói gyakorlat a halotti tor és a szokásos minőségü és méretü síremlék állításának ellenértékét hagyatéki

\footnotetext{
${ }^{926}$ Fabó 2014a. 745-746.

${ }^{927}$ BH 1990. 338.

${ }^{928}$ Fabó 2014a. 746.

${ }^{929}$ Ptk. 7:98. §

${ }^{930}$ Fabó 2014a. 740.

931 BH 1979. 181.

${ }^{932}$ Fabó 2014a. 740.
} 
tartozásnak minősíti. Utóbbival kapcsolatos költségek csak olyan mértékben számíthatóak fel, amilyen mértékben az örökhagyó emlékének megőrzését szolgálják. ${ }^{933}$

A temetési költségek viselése nem egyenlő az eltemetés kötelezettségével. Ennek a kötelezettségnek a temetőkről és a temetkezésről szóló 1999. évi XLIII. törvény 20. $\S$ alapján köteles személyeknek ${ }^{934}$ kell eleget tenni. Az illő eltemetés költségének viselésére kötelezettek köre - az örökösök számától függően - általában szélesebb.

\subsubsection{A hagyatéki költségek és a hagyatéki eljárás költségei}

A hagyaték megszerzése önmagában nem jár költséggel, azonban a hagyatékba tartozó vagyontárgyak feletti rendelkezési lehetőség megszerzése azzal járhat. ${ }^{935} \mathrm{Az}$ öröklési illeték megfizetése a hagyaték megszerzésének nem feltétele, hanem annak következménye, ezért nem esik a hagyaték megszerzésével járó költség fogalma alá. ${ }^{936}$ Ez utóbbi csoportba tartoznak viszont egyrészt a Hetv. 32. § szerinti biztosítási intézkedés költségei, másrészt a törvény 72 . § (1) bekezdésében ${ }^{937}$ nevesített tartozások.

\subsubsection{Az örökhagyó tartozásai}

Mindazok a jogok és kötelezettségek, amelyek nem polgári jogi jogviszonyból erednek, valamint amelyek az örökhagyó személyéhez kötődnek (pl. haszonélvezeti

${ }^{933}$ BH 1990. 300., BH 1996. 367., Vékás - Weiss 2501.

934 1999. évi XLIII. tv. 20. § (1) A temetésről sorrendben a következők kötelesek gondoskodni:

a) aki a temetést szerződésben vállalta;

b) akit arra az elhunyt végrendelete kötelez;

c) végintézkedés hiányában elhunyt temetéséröl az elhalálozása előtt vele együtt élő házastársa vagy élettársa;

d) az elhunyt egyéb, közeli hozzátartozója a törvényes öröklés rendje szerint.

(2) Ha temetésre kötelezett személy nincs, ismeretlen helyen tartózkodik, vagy a kötelezettségét nem teljesíti, a temetésről az elhalálozás helye szerint illetékes települési önkormányzat (fövárosban a kerületi önkormányzat) polgármestere, illetve ha az elhalálozásra a fövárosi önkormányzat által közvetlenül igazgatott területen kerül sor, a föpolgármester - jogszabályban meghatározott határidőn belül gondoskodik.

935 Fabó 2014a. 742.

936 BDT 2013. 2975.

${ }^{937}$ Hetv. 72. § (1) A hagyatéki eljárás költsége:

a) a közjegyzőt a közjegyzői díjszabásról szóló jogszabály szerint megillető munkadíj és költségtérítés (közjegyzői díjazás),

b) az ügygondnok eljárásának külön jogszabályban meghatározott díja és költségtérítése (gondnoki díjazás),

c) a biztosítási intézkedés elrendelésével és foganatosításával kapcsolatban felmerült, külön jogszabályban meghatározott költség (biztosítási intézkedés költsége), valamint

d) a külföldi hatósághoz intézett megkereséssel összefüggésben felmerült költség. 
jog), kívül esnek az öröklési jog által rendezett életviszonyokon, a hagyaték, ezen belül a hagyatéki tartozások fogalmán. ${ }^{938}$ „Az egyes jogviszonyok konkrét tartalmi vizsgálata alapján dönthető el az, hogy az egyébként az örökhagyó életében őt terhelő tartozás hagyatéki tartozásnak minősül-e, terheli-e az örököst." ${ }^{\text {939 }}$

$\mathrm{Az}$ örökhagyó tartozásai az utóbbi évtizedekben sokkal nagyobb arányban találhatók meg a hagyatéki terhek között, mint néhány évtizeddel ezelőtt, amikor az a)b) pontok szerinti követelések tették ki azok jelentősebb részét. ${ }^{940} \mathrm{Az}$ ebbe a csoportba tartozó követelések az örökhagyó halála elött keletkezett jogviszonyon alapulnak, feltéve, hogy az örökhagyó halálakor még fennállnak, ${ }^{941}$ az viszont lényegtelen, hogy az örökhagyónak a jogviszonyból eredő kötelezettsége halála előtt esedékessé vált-e, vagy sem. $^{942}$

\subsubsection{A kötelesrészen alapuló kötelezettségek}

Kötelesrész illeti meg az örökhagyó leszármazóját, házastársát és szülöjét, ha az öröklés megnyílásakor az örökhagyó törvényes örököse vagy végintézkedés hiányában az lenne. ${ }^{943}$ A kötelesrészen alapuló részesedés nem minősül öröklésnek, amit mutat az is, hogy az elévülhetetlen öröklési igénnyel ${ }^{944}$ szemben a kötelesrész iránti igény öt év alatt elévül, ${ }^{945}$ és azt a hagyaték terhére kell kiadni. ${ }^{946}$

Az öröklési rendelet tárgyi hatályáról már a preambulum is szól: a rendelet hatályának ki kell terjednie a hagyaték öröklésének valamennyi polgári jogi szempontjára, azaz a vagyontárgyak, jogok és kötelezettségek haláleset miatti átszállásának valamennyi formájára, akár végintézkedés szerint megvalósuló átruházás, akár törvényes öröklés révén átszállás útján történik. ${ }^{947}$ Ez a rész nem tesz említést a kötelesrészröl, melyet több európai ország jogrendszere is ismer, (például német, osztrák, holland, lengyel) ${ }^{948}$ és már a római jog óta egyfajta sajátos örökösödés: egy létező, érvényes és hatályos végrendelet ellenére az örökhagyó meghatározott

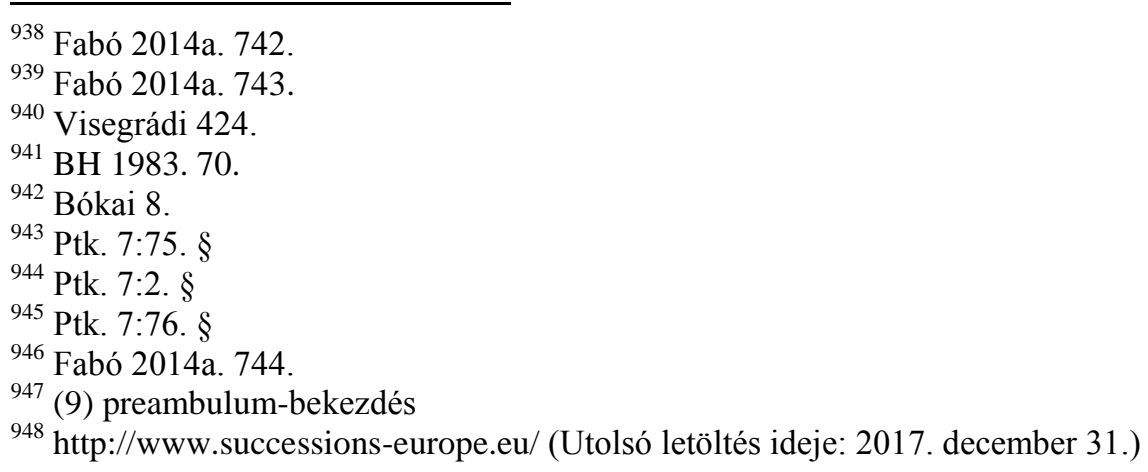


legközelebbi hozzátartozóinak a hagyatékból járó minimumrészesedése. Magyar eredetét keresve az Ideiglenes Törvénykezési Szabályokig kell visszamenni. ${ }^{949}$ A kötelmi típusú (római jogi) és az öröklési típusú (pl. francia, olasz) kötelesrész ismérveit összekeverték, megalkotva ezzel a törvényes osztályrészt, egy alapvetően öröklési igényü jogintézményt, amely jellemző főképp abban jutott kifejeződésre, hogy a kötelesrészt sértő részben a végrendelet semmis volt. ${ }^{950} \mathrm{~A}$ kötelesrész a mai magyar magánjog alapján kötelmi jogi igény, azaz az elévülhetetlen öröklési igénnyel szemben a kötelesrész iránti igény öt év alatt elévül, hiába keletkezik az igényre való jogosultság az örökhagyó halálával. ${ }^{951}$ A kötelesrészre jogosult tulajdonképpen hagyatéki hitelező. ${ }^{952}$ A bírói gyakorlat alapján:

- jogi természetét tekintve a kötelesrészi igény nem öröklésnek, a kötelesrész pedig nem örökségnek, hanem az örökösökkel és az örökhagyó által megajándékozottakkal szembeni kötelmi igénynek minősül; ${ }^{953}$

- a kötelesrészre jogosult nem tartozik az örökösök körébe ${ }^{954}$

- a kötelesrész iránti igény a hagyaték megnyílásával keletkezik, és követelési jogot biztosít a jogosultnak a kötelesrész érvényesítésére; ${ }^{955}$

- a hagyatékból minden tehertől és korlátozástól mentesen kell kiadni, ${ }^{956}$ elsősorban pénzben; ${ }^{957}$

- nem évül el az állagöröklésre, dologi hagyományra irányuló igény, mert azok tulajdoni jellegüek, ezzel szemben ötéves elévülés alá esik a kötelesrész, a kötelmi hagyomány, etc., mert ezek kötelmi alappal rendelkeznek. ${ }^{958} \mathrm{Az}$ elévülés nyugvására vezető igényérvényesítési akadálynak minősül, ha a kötelesrészre jogosult számára csak a hagyaték megnyílása után válik egyértelművé, hogy a hagyatékban nem a törvényes öröklés rendje érvényesül, s mi a hagyaték köre, ${ }^{959}$

\footnotetext{
${ }^{949}$ Fabó 2014b. 670.

${ }^{950}$ Vékás 2014b. 127.

${ }^{951}$ Ptk. 7:2. §, 7:76. $\S, 7: 87 . \S$

${ }^{952}$ Ptk. 7:94. $\S$ (1) bek. d) pont

${ }^{953}$ BH 2014. 306.

${ }^{954}$ BH 1980. 248., BH 2004. 113., EBH 2005. 1212.

${ }^{955}$ BH 1995. 343., BH 1996. 152.

${ }^{956} \mathrm{BH}$ 1988. 230.

${ }^{957} \mathrm{BH} 2001.475$.

958 BH 2005. 176.

${ }^{959}$ BH 2016. 62.
} 
- az öröklésből kiesettnek tekintendő a kitagadott, aki a kitagadás érvénytelensége esetén is csak kötelesrészre jogosult. ${ }^{960}$

A jogintézmény öröklési jogi könyvben történt elhelyezése azért indokolt, mivel ez a rész határozza meg, ki lehet örökös, milyen alaki és tartalmi kellékek kellenek a végrendelethez, amellyel a törvény rendelkezéseit „meg lehet kerülni”, ${ }^{961}$ kötelesrészre szorítva ezzel az egyébként törvényes örökösnek minősülő hozzátartozót. Az idézett rendeletbeli rész ugyan nem említi meg a kötelesrészt, ez a hiány nem jelenti a jogintézmény szabályozás alóli kizártságát.

\subsection{A hagyatéki tartozásokért való helytállás}

A hagyatéki tartozásokért való helytállás fő szabálya a Ptk. 7:96. §-ban található meg, mely szerint az örökös a hagyatéki tartozásokért a hagyaték tárgyaival és azok hasznaival (cum viribus hereditatis) felel a hitelezőknek. Ha a követelés érvényesítésekor a hagyaték tárgyai vagy hasznai nincsenek az örökös birtokában, az örökös öröksége erejéig egyéb vagyonával is (pro viribus hereditatis) felel. „Az örökös a törvény erejénél fogva korlátozott felelősséggel tartozik anélkül, hogy felelőssége korlátozásáért bármely jogcselekményt kellene tennie."962

A cum viribus felelősség azon a megfontoláson alapul, hogy a hagyatéki hitelezőknek egyébként is ez a vagyontömeg állt volna rendelkezésükre követelésük fedezetéül. Ha az örökös a hagyatéki tartozásokért a hagyaték tárgyaival és annak hasznaival felel, akkor az öröklési perben meghozott ítéletnek a rendelkező részében meg kell jelölni azokat a vagyontárgyakat, amelyekből, illetőleg amelyeknek hasznaiból a hitelező végrehajtás útján kielégítést kereshet. Amennyiben a kielégítés alapjául szolgáló hagyatéki vagyont haszonélvezeti jog terheli, az ítéletben alperesként perbe vont haszonélvezőt türésre kell kötelezni. ${ }^{963}$ Ezzel szemben a pro viribus felelősség gazdasági tartalma az, hogy az eredetileg meglévő vagyontárgyak helyébe lépnek az azok értékének megfelelő bármely más vagyontárgyak, amelyből a hitelező kielégítést

\footnotetext{
${ }^{960}$ BH 2010. 275.

961 Vékás 2013. 1022.

962 Bókai 9.

${ }^{963}$ BH 1981. 106.
} 
szerezhet végső fokon szintén végrehajtás útján. ${ }^{964}$ A készpénzörökség - elhasználható dolog lévén - fogalmilag pro viribus felelősséget jelent. ${ }^{965}$

A törvényszövegben található hasznok kifejezés alatt a hagyatéki vagyontárgyaknak az öröklés megnyílása után keletkezett hasznait kell érteni, mert az öröklés megnyílása előtt beszedett hasznok hagyatéki vagyonként szállnak át az örökösre. $^{966}$

A PK 192. számú állásfoglalás, amely az 1/2014. PJE határozat alapján a hatályos kódex alkalmazása körében is megfelelöen irányadó, a hagyatéki tartozásokra vonatkozó bírói gyakorlatot ${ }^{967}$ összegzi. A cum viribus felelősség ítéletbeli megfogalmazásának módja mellett a határozat szerint pro viribus felelősség esetén nincs szükség a vagyontárgyak körülírására, és még csak arra sem kell utalni, hogy az örökös felelőssége milyen érték erejéig áll fenn. Ezeket az indokolásban kell megfogalmazni, a rendelkező részben további korlátozás nélkül csak a meghatározott összeg fizetésére kell kötelezni, ami azonban az örökség értékét nem haladhatja meg. Ezen a körön kívül esnek a Ptk. 7:96. § (3) bekezdése alapján a hagyatéki költségek és a hagyatéki eljárás költségei, amelyekért az örökös a saját vagyonával is felel. A jogalkotó ezzel a bekezdéssel a korábban kialakult bírói gyakorlatot ${ }^{968}$ emelte törvényi szintre.

A házastárs a haszonélvezetével terhelt vagyonból türni köteles a hitelezők követeléseinek kielégítését a hagyományon és a meghagyáson alapuló követelések kivételével. A kivétel alá eső igényeket az özvegyi jog alá nem eső vagyontárgyakból, illetve az özvegyi jog megszünése után lehet kielégíteni. ${ }^{969}$

A Ptk. 7:96. $§(2)$ bekezdése szerint azokat a vagyontárgyakat, amelyek nem kerültek az örökös birtokába, továbbá azokat a követeléseket és egyéb jogokat, amelyek nem voltak érvényesíthetők, valamint az átvett vagyontárgyak meg nem levő hasznait annyiban lehet az örökös felelőssége megállapításánál figyelembe venni, amennyiben az örökös ezektől neki felróható okból esett el.

\footnotetext{
${ }^{964}$ Fabó 2014a. 747-748., Orosz 2014c. 309-310.

965 BH 1997. 82.

966 Complex CD-jogtár 1959. évi IV. törvény 679. §-hoz füzött magyarázata

${ }^{967}$ BH 1980. 473., BH 1981. 106.

968 BH 2006. 51.: A hagyatéki eljárás lefolytatásával a jogszabályban meghatározott munkadíjra, költségtérítésre a közjegyző az örökössel szemben nem hagyatéki hitelezőként tarthat igényt, így az öt hagyatéki vagyon hiányában is megilleti. Ugyanezt tartalmazzák a BH 2006. 212. és az EBH 2005. 1213. döntések is.

${ }^{969}$ Ptk. 7:96. § (4) bek., Orosz 2014c. 310.
} 
Fontos hangsúlyozni, hogy az örökös helytállási kötelezettsége csak akkor áll fenn, ha a hagyatékot ingyenesen szerezte. Az öröklési szerződés alapján a hagyatéki vagyontárgyakat megöröklő személy - a szerződéses örökös - a hagyatéki tartozásokért nem felel, tartalma szerint ugyanis tartás vagy életjáradék, aminek a fejében kapja a lekötött vagyontárgyat, ${ }^{970}$ azaz visszterhes szerzésmódról van szó. A Legfelsőbb Bíróság több döntésében is utalt arra, hogy a szerződéses örökös az örökhagyó legtöbb tartozásáért nem felel. ${ }^{971} \mathrm{Ez}$ alatt a tartozás alatt a c) pontos hitelezőket kell érteni, ha erről a kizártságról van szó, ezekért csak akkor felel a szerződéses örökös, ha a lekötött vagyontárgyon (így akár az üzletrészen) zálogjog áll fenn. Az a) és b) pontos tartozásokért a szerződés jellegénél fogva helytáll, a hagyományokért és a meghagyásokért a szerződés ilyen kikötése esetén, míg a kötelesrészre vonatkozóan az ún. kétéves szabály ${ }^{972}$ alkalmazandó. ${ }^{973}$ A szerződéses örökös is az örökhagyó egyetemes jogutóda, ez az egyetemesség pedig, ahogy az már említésre került, azt jelenti, hogy az aktívákkal együtt a passzívák is ugyan átszállnak, de a szerződés visszterhes jellege miatt nem felel a tartozásokért, pontosabban nem kell helytállnia. ${ }^{974}$

\subsection{Több örökös helytállása}

Az örököstársak a közös hagyatéki tartozásokért mind a hagyatéki osztály előtt, mind azt követően egyetemlegesen felelnek. ${ }^{975}$ Orosz Árpád szerint az egyetemleges felelősség végső soron azt jelenti a felek közötti elszámolás viszonyában, hogy itt is érvényesülnie kell a cum, illetve pro viribus felelősségnek, az egyetemleges adósok korlátolt felelősségi szabályaival együtt. ${ }^{976}$ A felelősség alapja az, hogy az örökösök jogközössége nemcsak jogosultak, hanem kötelezettek kockázatközösségévé is válik. A hagyatéki hitelezői igény - az egyetemlegesség folytán a törvényben meghatározott korlátozás mellett - bármelyik örökössel szemben érvényesíthető, valamennyi örököstárs perben állására tehát nincs szükség. ${ }^{977}$ A bírói gyakorlat további kapcsolódó döntés is született: a hagyatéki tartozásokért az örökösök felelössége egymás közti

\footnotetext{
${ }^{970}$ Visegrádi 427.

${ }^{971}$ BH 1981. 407., BH 1988. 401.; Gellért 123.

972 A szabály kiváló elemzését adja Leszkoven László, lásd Leszkoven 69-86.

973 Vékás - Weiss 2431-2432.

${ }^{974}$ Anka 2014c. 599.; K-H-PJ-2015-336. bírósági határozat

975 Ptk. 7:97. § (1) bek.

976 Orosz 2014c. 311.

${ }^{977}$ BH 1988. 402., Fabó 2014a. 750.
} 
viszonyukban a hagyatékban való részesedés mértékéhez igazodik, s ezen nem változtat az sem, ha az egyik örököstárs egyben hagyatéki hitelező is. ${ }^{978}$

Nem lehet figyelmen kívül hagyni az alábbi álláspontot sem, amellett, hogy az egyetemlegesség alkalmazhatóságát elfogadhatónak tartom: „Az egyetemlegesség szabályai a prudens örököst veszélyeztetik, aki előbb kerül a hitelezői igények célpontjába, mint az a vagyontalan örökös, aki még örökségét is pillanatok alatt feléli, és vele szemben bármilyen követelés behajthatatlan, beleértve a helyette (is) helytálló teljesítő örököstárs megtérítési igényét." ${ }^{979}$ Meglátásom szerint - ez az egyébként extrémnek tünő - példa ellenére is fenn kell tehát tartani az örököstársak egyetemlegességét, mert ezzel a módszerrel biztosítható az örökösök örökrészüknek megfelelő helytállása, és nem kell olyan tartozásért helytállni, amely csupán saját magánvagyonuk rovására lenne kielégíthető. Azért tartom védhetőnek az álláspontot, mert az örökhagyó életében csak az ő vagyona áll a hitelezői igények kielégítésére, hacsak például nem volt kezes, de nem ez a fö szabály.

Ha csupán a kötelezetti egyetemlegesség szabályait alkalmaznánk az örököstársaknál, akkor az azzal a következménnyel járna, hogy egyes örökösökkel szemben az örökrészük értékét meghaladó hagyatéki tartozás behajtására is sor kerülhetne. Az egyetemleges helytállás örököstársak esetén a kifelé fennálló felelősség korlátozott mértékét (a pro viribus felelősség elvét) nem törheti át, csak annak keretei között érvényesíthető, azaz minden kötelezettnél csak a saját felelőssége mértékéig. Az örökösök egymás közti (belső) jogviszonyára kihatóan hatályosulhat az a szabály [a döntéskor alkalmazandó régi Ptk. 338. § (1) bek., jelenleg Ptk. 6:30. § (1) bek.], hogy az örökösök a hagyatékból való részesedésük arányában felelnek a hagyatéki tartozásokért. Ha tehát valamelyikük a jogosultnak a saját kötelezettségét meghaladó követelést teljesített, örököstársaival szemben a követelésnek őket terhelő része erejéig megtérítési igénye keletkezik. $^{980}$

\footnotetext{
${ }^{978}$ BH 1990. 338.

${ }^{979}$ Fabó 2014a. 750.

980 ÍH 2011. 163., „Az örökösök a hagyatéki osztály után egymással szemben - az egyetemleges kötelezettek belső viszonyát rendező szabály szerint - megtérítési igényt érvényesíthetnek.” Lásd még: Vékás 2013. 1031.
} 


\subsection{A tartozások kielégítése}

Az örökös a hagyatéki tartozásokat a kielégítés sorrendjének megtartása nélkül elégítheti ki mindaddig, amíg felteheti, hogy a hagyatéki tartozásokat a hagyaték teljesen fedezi, ha figyelmen kívül hagyja az örökhagyó által élők között ingyenesen vállalt, valamint a hagyományon és meghagyáson alapuló kötelezettségeket. Ellenkező esetben csak a sorrend szerint nyújthat kielégítést. ${ }^{981}$ „Az örökös a kielégítés sorrendjének megtartását csak akkor mellőzheti, ha a hagyaték aktív és passzív oldalát számba vette, ezeket az általános társadalmi felfogáshoz képest józanul és reálisan mérlegelte és e mérlegelés eredményeként a hagyaték a tartozások fedezésére elegendőnek mutatkozik."982 Az a hitelező, akinek a hagyatékhoz tartozó valamely vagyontárgyon zálogjoga van, a biztosíték erejéig - a hagyatéki tartozások sorrendjében elfoglalt helyére tekintet nélkül - teljes kielégítést kereshet. ${ }^{983}$

Ha az örökös ezeket a szabályokat neki felróhatóan megszegi, az emiatt kielégítetlenül maradt hitelezővel szemben egész vagyonával felel, ${ }^{984}$ azaz elveszíti a korlátolt felelősség kedvezményét. ${ }^{985}$ „Annak kockázatát, hogy az örökös jól mérlegelte, amikor a sorrendtől való eltéréssel teljesít a hitelezőknek, illetve a privilegizált hitelezőnek tényleg csak a zálogfedezet erejéig biztosított elsőbbséget, az örökösre telepíti: a szabályok felróható megszegése esetén egész vagyonával felel a kielégítetlen követelés hitelezőjének, de csak akkor, ha ennek oka a szabályok felróható megszegése volt." $" 986$

\subsection{Társasági jogi relevanciák}

A gazdasági társaságok csoportosítása többek között az alábbi szempontok alapján lehetséges: a tagi együttmüködés, a társaságok által végezhető tevékenység, taglétszám, tagi felelősség, alapításkori vagyon és a bejegyzési eljárás jellege. ${ }^{987}$ Ezek közül a tagi felelősség az egyik legfontosabb ismérv, miután az egyes gazdasági társaságok törvényi fogalmában ${ }^{988}$ és a tagok általi társasági forma kiválasztásában

\footnotetext{
${ }^{981}$ Ptk. 7:98. § (1) bek.

982 Világhy 125.; Idézi: Orosz 2014c. 312.

${ }^{983}$ Ptk. 7:98. § (2) bek.

${ }^{984}$ Ptk. 7:98. § (3) bek.

985 Orosz 2014c. 312.

${ }^{986}$ Fabó 2014a. 752.

${ }^{987}$ Papp 2011b. 48-49.

${ }^{988}$ Ptk. 3:138. §, 3:154. §, 3:159. §, 3:210. §
} 
jelentős szerepet tölt be az induló vagyon mértéke mellett. Ezek közül a tagi felelősség szempontjából történő osztályozás aszerint történik, hogy a társaság tagjai a társaság tartozásaiért mögöttesen, korlátlanul és egyetemlegesen helytállnak-e, (lásd a kkt. tagjai és a bt. beltagja) vagy a tagok nem tartoznak helytállással a társaság tartozásaiért, (lásd a bt. kültagja, a kft. tagja és a részvényes). A tagi felelősség jellegének jelentős szerepe van a hagyatéki tartozásokért való felelösség vonatkozásában is.

Meglátásom szerint mindegyik típusnál igaz az az állítás, miszerint amennyiben - miután a társasági szerződés arra lehetőséget adott ${ }^{989}$ - olyan tag halálozik el, aki még nem teljesítette teljes mértékben a vagyoni hozzájárulását, a kötelezettség a hagyatékának erejéig átszáll az örökösökre.

\subsubsection{A hagyatéki tartozásokért való felelösség a közkereseti társaságban és a betéti társaságban}

A közkereseti társaság és a betéti társaság közötti szoros kapcsolatot a Ptk. 3:155. § határozza meg: a betéti társaságra - a rá vonatkozó címben foglalt eltérésekkel - a közkereseti társaságra vonatkozó rendelkezéseket kell megfelelően alkalmazni. Figyelemmel arra, hogy e szegmensben nem tartalmaz eltérést, a közkereseti társaság vonatkozásában megállapítottak irányadóak a betéti társaságra is.

A hagyatéki tartozásokért való felelösség természetesen csak a társaság tagjának halála esetén merülhet fel. A tagsági jogok és kötelezettségek nem képezik a hagyaték tárgyát, ezek nem szállnak át a maguk változatlan formájában, ipso iure nem válik az örökös taggá, ennek magyarázata a társaság személyegyesítő jellegében rejlik. ${ }^{990}$

Az örökösnek a 4.2.1. és a 4.2.2. pontokban ismertettek alapján lehetösége van arra, hogy tagként belépjen abba a társaságba, amelyben az örökhagyó tag volt, amennyiben a társaság többi tagjával így egyezik meg. ${ }^{991}$ A törvényszöveg megfogalmazásából pedig kitünik az, hogy az örökösnek nem kötelezettsége a társaságba történő belépés. Ha viszont belép a társaságba, ugyanolyan felelősséggel tartozik, mint bármely belépő tag, mint például akire egy korábbi tag átruházta a társasági részesedését, aki így - a Ptk. 3:139. § (4) bekezdése alapján - a belépése előtt keletkezett társasági kötelezettségekért a többi taggal azonos módon köteles helytállni.

\footnotetext{
${ }^{989}$ A közkereseti társaságnál és a betéti társaságnál a vagyoni hozzájárulás teljesítésére a Ptk. nem szabott meg határidőt. A kft. és a rt. vonatkozásában lásd a Ptk. 3:162-3:163. §-t, illetve a Ptk. 3:252. §-t.

990 Kisfaludi 2014b. 362.

${ }^{991}$ Ptk. 3:149. §
} 
A tagok ezzel ellentétes megállapodása harmadik személyekkel szemben nem hatályos. Ebben az esetben a meghalt tag örökösének helytállása a hagyatéki tartozásokért megoszlik. Habár a közkereseti társaságban a társasági vagyon által nem fedezett tartozások arányos része az örökhagyót terhelné, ami a Ptk. 7:94. § (1) bek. c) pontjába illeszkedő tartozás, a belépéssel helytállása alakulhat úgy, hogy először ő fizeti meg a tartozást a hitelező felé, és csak ezután számolnak el a tagok egymással. Minden más, a társasági részesedésen kívül általa örökölt vagyontárgyakkal, illetve az azok helyébe lépő értékkel a hagyatéki tartozásokért való felelősség általános szabályai lesznek az irányadóak.

Közkereseti és betéti társaságok esetében a hagyaték tárgya (a társasági részesedésen kívüli hagyatékkal együtt) a meghalt tagot kiválása esetére megillető elszámolási igény. ${ }^{992}$ Ezzel az elszámolási igénnyel kapcsolatosan lesz az a joga, hogyha belép, akkor ne kelljen a társaság felé vagyoni hozzájárulást teljesíteni, hacsak eltérően nem egyezik meg a társaságban maradt tagokkal. Az elszámolási igény kiszámolását a Ptk. 3:150. § (2) bekezdése akként adja meg, mekkora a kiváló (elhunyt) tag vagyoni hozzájárulásának aránya a tagsági jogviszony megszünésének (az örökhagyó halálának) időpontjában megállapított társasági vagyon forgalmi értékében. $^{993}$

Az örökösnek arra is lehetősége van, hogy ne lépjen be a társaságba, ebben az esetben a tag halálától számított ötéves jogvesztő határidőn belül a hagyatéki tartozásokért való felelősség szabályai szerint köteles helytállni a tag halála elött keletkezett társasági tartozásokért. ${ }^{99}$ A társaságba be nem lépő örökös jogállása speciális. ${ }^{995}$ A társasági vagyon által nem fedezett kötelezettségek nem társasági jogi alapon terhelik, hanem az öröklési jog szabályai szerinti korlátozott felelősség alapján, ugyanis a jogszabály a hagyatéki tartozások között nem tesz különbséget azok „forrása” (jogcíme) alapján. Az örökös által megörökölt, az örökhagyó mögöttes helytállási kötelezettségén alapuló tartozások ezért a cum, illetve pro viribus felelősség szabályai szerint fognak kielégítést nyerni. A társaság hitelezői a hitel kockázatának felmérésekor ugyanis a tagok mögöttes helytállásával is számoltak, nem kerülhetnek előnytelenebb

\footnotetext{
992 Papp Tekla professzor asszony a Szegedi Tudományegyetem Állam- és Jogtudományi Karán 2015. március 27-én elhangzott Társasági jog II. előadása alapján.

$993 \mathrm{Az}$ üzletrészek forgalmi értékével kapcsolatban lásd Pázmándi 2015. 9-10, amely irányadó a közkereseti és a betéti társaságnál is.

${ }_{994}$ Ptk. 3:151. § (2) bek.

995 Lásd még Barta 2016a. 11-12.
} 
helyzetbe a tag halála miatt, ${ }^{996}$ azzal, hogy pro viribus felelösség esetén fennállhat annak a veszélye, hogy az örökösnek nincs semmilyen vagyontárgya.

Egy eseti döntés szerint ${ }^{997}$ a közkereseti társaság tagja és a betéti társaság beltagja csak a tagsági jogviszonya megszünéséig esedékessé vált társasági tartozásokért köteles helytállni. Meglátásom szerint ez jogszabályt szükítő értelmezés; az ítélet meghozatalakor hatályos Gt. 104. § (1) bekezdése és a Ptk. 3:151. § (1) bekezdése egyaránt rögzíti a tagnak a tagsági jogviszony megszünéséig keletkezett tartozásokért való helytállási kötelezettségét. Ez a gyakorlat, amelyre a Ptk.-hoz kapcsolódó egyik kommentár is irányadóként tekint - ráadásul a társaságba be nem lépő örökös helytállása kapcsán -, ${ }^{998}$ a volt tag, illetve az örökös számára kedvezőbb.

Ugyanezen szabályok irányadóak a betéti társaság beltagjának halála esetén is, mert a betéti társaságra a közkereseti társaságra vonatkozó rendelkezéseket megfelelően kell alkalmazni, ha nincs más szabály, ilyet pedig - ahogy jeleztem - nem találunk. A kültag a törvényi fogalom alapján ${ }^{999}$ csak a vagyoni hozzájárulás teljesítésére köteles, azon túlmenően eltérő rendelkezés hiányában nem felel a társasági vagyon által nem fedezett tartozásokért. ${ }^{1000}$

\subsubsection{A korlátolt felelösségü társaságok és a részvénytársaságok}

A betéti társaság kültagjához hasonlóan a korlátolt felelősségü társaság tagjának, illetve a részvényes örököse sem felel azokért a tartozásokért, amiket nem fedez a társaság vagyona, miután - eltérö rendelkezés hiányában - nem felel a tag sem. Ettől eltérő rendelkezésnek minősülnek például az apport túlértékelése, ${ }^{1001}$ illetve annak rosszhiszemű elfogadása ${ }^{1002}$ vonatkozásában felmerülő felelősségi kérdések (lásd a 4.2.3. pontban), ha azokért az örökhagyó nem állt helyt: az ilyen igényekért a hagyatéki tartozásokért való felelősség szabályai szerint az örökösöknek is helyt kell állniuk.

Korlátolt felelősségü társaságoknál az üzletrész örökölhetőségét a jogalkotó explicit módon nem jelenti ki, csupán utal rá a 3:170. § [Az üzletrész öröklése és átszállása a jogutódra] címében. A hivatkozott szakasz szerint az elhalt tag örököse - e

\footnotetext{
996 Kisfaludi 2014b. 363.

${ }^{997}$ BH 2013. 130.

${ }^{998}$ Nochta 2014b. 566

999 Ptk. 3:154. §

${ }^{1000}$ Lásd még Barta 2017. 85-86.

${ }^{1001}$ Ptk. 3:10. § (3) bek.

${ }^{1002}$ Ptk. 3:98. § (2) bek.
} 
minőségének igazolása mellett - kérheti tagként való bejegyzését az ügyvezetőtől. A részvény, mint értékpapír önmagában forgalomképes, azzal kapcsolatban a közkereseti társaságnál és a betéti társaságnál tárgyalt problémafelvetésekkel nem találkozhatunk. A hagyatéki tartozásokért való felelősség kérdései - a korlátolt felelősségü társasághoz hasonlóan - itt is csak a törvényben külön szabályozott esetekben merülhet fel.

A korlátolt felelősségü társaság létesítő okirata, valamint a részvénytársaság alapszabálya rendelkezhet úgy, hogy az üzletrészt, illetve a részvényt forgalomképtelenné teszi, utóbbi esetben - a Ptk. 3:240. §-ban foglalt jogalkotói felhatalmazással élve, a részvény által megtestesített tagsági jogok tartalma és mértéke meghatározása mellett - akár olyan részvény megalkotásával is, amely egyik, a kódexben szabályozott részvényfajtába sem illeszthető be. Ebbe a sorba illeszkedik a dolgozói részvény is sajátos forgalomképessége miatt. Ezekben az esetekben az örökös az üzletrész és a részvény értékére tarthat igényt. Vagyontárgy hiányában pedig ezekhez kapcsolódóan az örökös pro viribus felelössége áll fenn. ${ }^{1003}$

\subsection{A hagyatéki tartozások osztrák szabályozásáról}

Az örökség átvételére irányuló nyilatkozatnak tartalmaznia kell azt, hogy az átvétel feltételes vagy feltétel nélküli, a kettő közötti különbség az örökös részére történt hagyatékátadást követő felelősségében rejlik. Alapvetően igaz az, hogy az átvételi nyilatkozatnak feltétel nélküli akaratnyilatkozatnak kell lennie, mert a feltételt és az időtűzést tartalmazó nyilatkozat nem megengedett, és az nem is váltja ki a kívánt joghatást, a két feltétel kifejezés azonban nem ugyanazt a fogalmat takarja. ${ }^{1004}$

A feltétel nélküli átvételi nyilatkozat az örökségnek felelősségkorlátozás nélküli átvétele, ami azt jelenti, hogy a hagyatéki kötelezettségekért személyesen, azaz teljes, saját vagyonával is felelős. Ugyan a feltételes átvételi nyilatkozattal átvett tartozásokért is személyében felelős, de a magyar pro viribus hereditatis szabályaival egyezően csupán a rá, öröklés útján átszálló hagyatéki vagyontárgyak értékével. Ez a korlátozás a hagyatéki eljárás során felmerülő eljárási költségekre is érvényes, ellentétben a Polgári Törvénykönyvbe a bírói gyakorlat által kimunkált tételek felvételével. A feltételhez kötött nyilatkozatot leltárkedvezménnyel („,cum beneficio inventarii”) átvett örökségnek

\footnotetext{
1003 A hagyatéki tartozásokért való felelősség és a társasági jog kapcsolatát vizsgálja még Harsányi Ujváriné - Miskolczi Bodnár 229-230. is.

${ }^{1004}$ Welser 567-568.
} 
is nevezik, ezt a lehetőséget az eljáró hatóság nem észleli hivatalból és a leendő örökösnek bizonyítási kötelezettsége áll fenn, ami abban áll, hogy már olyan sok kötelezettséget kielégített, hogy az megfelel a hagyaték értékének. Ennek előnye, hogy a továbbiakban felmerülő tartozásokat nem kell kielégíteni, ellentétben a feltétel nélküli nyilatkozatot tevő személyeknek. ${ }^{1005}$

Hagyatéki tartozásnak minősülnek az örökhagyó örökölhető tartozásai, az örökléshez kapcsolódó tartozások, így többek között a temetés költségei, kötelesrészi igények, hagyomány, meghagyás, örökölhető tartási igények, a hagyaték megszerzésével kapcsolatos költségek, pl. leltározás költsége, a hagyatéki eljárás költsége. ${ }^{1006}$

\section{8. Összegzés}

A hagyatéki tartozásokért való felelősség kérdésével a szakirodalom és a bírói gyakorlat is sokat foglalkozott, tekintettel annak az öröklési jogon belül betöltött fontos szerepére. E körben viszonylag tisztázott, alaposan kimunkált rendelkezések vannak a törvénykönyvben, amely már a vonatkozó bírói gyakorlatot is beemelte a jogszabályi rendelkezések közé. Ennek ellenére az élet hozhat olyan szituációkat - például egy, a magyar jogtól idegen, speciális jogintézmény vagy például társasági jogi megoldás átvétele, amelynek öröklési jogi kihatása is van - amelyek a szabályok újabb értelmezésére szorítják a jogalkalmazót.

Habár a társasági jog alapvetően a társaság tagjaitól elkülönülő gazdasági társaságok alapítását, müködését és megszünését szabályozza, nem hagyhatóak figyelmen kívül azok a rendelkezések, amelyek a társaság elhalt tagja vonatkozásában szabályokat tartalmaznak. Ezek alkalmazása nem volna lehetséges a vonatkozó öröklési jogi szabályok ismerete nélkül. A megállapítás a másik irányban is igaz: a társasági jogi részesedéssel bíró örökhagyó utáni öröklés rendezése nemcsak a Ptk. öröklési jogot tartalmazó Hetedik Könyvét igényli, hanem figyelemmel kell lenni a speciális szabályokra is. Az egyik ilyen kérdéskör a hagyatéki tartozások kielégítése.

\footnotetext{
1005 Welser 567-569.

1006 Apathy 99.
} 


\section{Záró gondolatok}

$\mathrm{Az}$ értekezés kiindulópontjaként rögzített kutatási kérdés, amely szerint a társasági jog az elhunyt tag társasági részesedésének öröklése esetén eltéríti az öröklési jogot, álláspontom szerint megfelelően bizonyításra került. A személyegyesítő jelleget magán hordozó közkereseti és betéti társaság részesedésének megszerzése, ha az örökös taggá kíván válni, akként történhet, hogy megegyezik a társaság életben maradt tagjaival a belépésről, de ha nem akar belépni, úgy megszerezheti elődje részesedésének értékét megváltási igényként, az örökhagyó halála előtt keletkezett kötelezettségekért azonban helyt kell állnia az irányadó szabályoknak megfelelően. Az üzletrészek öröklése esetén kérdésként arra kell választ adni, hogy miután az örökös kéri az ügyvezetőtől a tagként való bejegyeztetését, már amennyiben kéri, van-e a társasági szerződésben az üzletrész megváltására feljogosított személy, és ha igen, akkor egyáltalán ő ezzel a jogával élni kíván-e. Az esetleges további, bekövetkező esetekre figyelemmel megfontolásra lenne érdemes a társasági részesedésen fennálló haszonélvezeti jog cégjegyzékbe való bejegyzése az üzletrészen fennálló zálogjog mintájára. A részvénytársaság vonatkozásában a dolgozói részvények megszerzése vet fel problémákat, amely megoldását már a törvény is tartalmazza, azonban azokat céljuknak megfelelően kell értelmezni. A cél e tekintetben az, hogy dolgozói részvény ne állhasson huzamosabb ideig olyan személy tulajdonában, aki nem a részvénytársaság munkavállalója, ugyanakkor annak törvény folytán bekövetkező megszerzése esetén se essenek el annak ellenértékétől, miután ez a részvény is a hagyatékba tartozik.

A személyegyesítő társaságoknál a joggyakorlatban többször felmerült kérdés az, ha a halál folytán a törvényi minimum alá csökken a kkt. tagjainak száma, illetve a betéti társaságban nem lesz kültag vagy beltag, honnan kell számítani a társaság megszünésére, illetve nevezhető akár megmentésére előírt hathónapos határidőt. Hiába tartalmazták ezt pontosan a korábbi gazdasági társaságokra irányadó törvények (ugyan a korábbiakhoz képest már megemelt határidővel), illetve szerepel jelenleg is a Ptk.-ban, több közzétett eseti döntés a feleknek e jogszabályi hellyel összefüggő nem megfelelő értelmezéséről tett tanúbizonyságot. Még fajsúlyosabb volt a kérdés, amikor még nem került beiktatásra a határidő jogvesztő jellege, igazolási kérelemmel szerettek volna élni, holott erre a bíróságok álláspontja alapján nem kerülhetett sor. A döntésekben foglalt jogértelmezési problémák hatására de lege ferenda javaslat az, miszerint ne a 
haláltól, hanem a hagyaték közhitelü és végleges átadásától kelljen számítani a társaság megszünésére irányuló jogvesztő határidőt, amellyel orvosolni lehetne ezeket a félreértelmezéseket. Meglátásom szerint helyes az a jogalkotói álláspont, miszerint a közkereseti társaságok valóban csak rövid, átmeneti időre lehessenek egyszemélyes társaságok, ugyanakkor ezt az ismérvet haladéktalanul fel kell tüntetni a cégjegyzékben is a közhitelesség érdekében és azért, hogy a cégjegyzékbe betekintő személyek megismerhessék a társaság valóságnak megfelelö állapotát.

Betéti társaságok esetén lenne az megvalósítható, mintegy a kkt.-k alóli speciális kivételként, miszerint ha egyetlen kültagja volt a betéti társaságnak, és ennek halála folytán ez a jogi pozíció kiüresedik, mégis egynél több beltag marad, akkor automatikusan közkereseti társasággá alakuljon a betéti társaság, aminek megalapozottságát a jogtörténeti előzményként említendő Kt. szabályozásában látom. Egyfajta közkereseti társaság áll fenn a betéti társaság több beltagja között akkor is, ha ma ezt a törvény explicite nem is jelenti ki. Ha azt a megoldást választjuk, miszerint a tagsági jogviszony megszünésénél fogva nem marad kültag egy betéti társaságban, de továbbra is lesznek beltagok, akkor a hathónapos jogvesztő határidő leteltével, ha nem jelentettek be új tagot a kültagi pozícióra, vagy ők nem jelentették be közkereseti társaságként való folytatást, akkor ex lege átalakul a betéti társaság közkereseti társasággá. Így a betéti társaság, miután legalább két tagja lesz, megmaradhat annak ellenére, hogy a társaság formája megváltozik. A megoldás lehetséges folytatása az, hogy nem kell automatikusan módosítani a társasági szerződést, hanem azt csak akkor kell, ha egyéb okból annak módosítására van szükség.

A jogtörténeti fejezet alátámasztja azt, hogy az öröklés útján bekövetkező társasági jogi jogutódlás már a XIX-XX. század fordulóján is foglalkoztatta a magyar jogtudósokat, hasonló problémákat felfedezve, amelyek hatályos jogunkban is fellelhetőek, illetve próbálták az öröklési joggal összeegyeztetni a kereskedelmi társaságok vagyoni részesedéseinek öröklését. A kérdés fontosságát mutatja az, hogy neves elödeink is írtak erről a kérdéskörröl.

A származtatott alapítás eseteit, az eljárások egyes momentumait megvizsgálva is arra a következtetésre kell jutni, hogy először a társasági jog szabályait kell alkalmazni, és ha nem is azok hiányosságainak pótlására, hanem az öröklési jogviszonyra tekintettel kell alkalmazni azokat az eljárásban részt vevő társasági formának megfelelő jogutódlás alapján. 
A közös veszélyre irányadó hatályos, valamint a régi Ptk.-beli szabályozás fejezetben meghatározott, egyelöre hipotetikus helyzetekben eltérö eredményekhez vezethet a társaság tagjának halála, valamint figyelembe kell azt is venni, hogy a tagok egy család tagjai voltak-e vagy sem, az egymás utáni öröklés miatt, közülük kik voltak tagok, és mennyiben járt volna más eredménnyel az, ha a jogalkotó nem illesztette volna be a vélelmet. Látható az esetek alapos vizsgálata után, lényeges változás következett be a megújult szabályozással az egyes hipotetikus tényállásokban, amelyek azonban nem teljes mértékig elképzelhetetlenek.

A speciális társulások néven összefoglalt személy- és vagyonegyesülések különféle szempontok alapján csoportosíthatóak, bennük a társaság sajátosságaihoz illeszkedő szabályok kerültek megalkotásra, ennek hiányában ezeket a különlegességeket a szóba jöhető lehetőségek alapul vételével lehet feloldani. Az idesorolt családi társaság is különleges képződmény, valóban csak a tagság összetétele miatt kerül megkülönböztetésre, azonban az igényli az egyik választ, egy család mely tagjai részvétele esetén beszélhetünk családi vállalkozásról, egymáshoz felmenőileszármazói kapcsolatban álló személyek, ki kell-e terjeszteni a Ptk. 8:1. § (1) bekezdésének 2. pontja szerinti hozzátartozókon kívüli személyekre, amely személyeket egyébként a köznyelv még családtagoknak titulál. Több eseti döntésben megjelent már a kifejezés használata, általában, mint a tényállás elején szereplő információ, az indokolásban azonban nem kerül bővebb kifejtésre a fogalom, és a jogesetben szereplő cég tagjainak egymáshoz füződő rokoni szálaira sem derül feltétlenül fény. A velük kapcsolatos másik gócpont a jogutódlás kérdése, ahogy azzal az osztrák jogirodalom, a magyarhoz képest mindenképpen meglepően sokat foglalkozik. Az e helyen részletesen, illetve az értekezés egyes helyein érintőlegesen számba vett osztrák fragmentumok a jog-összehasonlító jellegen túl azt is hivatottak szolgálni, hogy egy jogcsaládba sorolt, egymással ráadásul szomszédos országok jogában, több évszázados történelmi kapcsolódás ellenére vannak olyan területek, amelyeknek ugyanazon kihívásaira, jelen esetben egy társasági tag halála utáni vagyoni viszonyok elrendezése mennyire más felelet adása lehet. Amennyiben meg kívánnánk adni a családi vállalkozás fogalmát, úgy ennek a fogalomnak mindenféleképpen elemévé kellene tenni a családi jelző meghatározását, hogy az előbbi kérdésre választ adva, itt nem csupán a Ptk. 8:1. § (1) bekezdésének 2. pontja szerinti hozzátartozók közötti társulás képezhetné az ilyen jellegü minőség odaítélését, hanem azon személyek között, akik rokonok a Ptk. 4:96. § alapján. A kiterjedt családi kapcsolatok feltérképezhetetlenségének érdekében ezt a kört 
a törvényes öröklésre jogosultak körére lenne célszerü szorítani. A vállalkozás fogalmi elem helyett, miután a vállalkozás a fogyasztói szerződésekhez kapcsolódó terminus technicus - a cég kifejezés használatát tartom megfelelőnek. Ez már csak azért sem okozhat fogalmi diszkrepanciát, mert az osztrák minta kitételei alapján - amiknek átvétele támogatandó - a cégek azok a jogi formák, amely formákban az ilyen jellegü társulásoknak létjogosultsággal rendelkeznek, ahol - ugyan nem teljes, de tolerálható mértékben, az adott cég sajátosságait teljes mértékig tiszteletben tartva - a vagyongyarapítás mellett a személyes közremüködésnek is helye lehet. A cég kifejezés azért is megfelelö, mert nem látom annak akadályát, hogy családi cégek feltétlen csak gazdasági társaságok lehetnének. Mindezeknek a külön jegyeknek a társasági pozíciók öröklésére is kihatással van: az adott cég sajátosságaira figyelemmel, amennyiben van neki öröklésbeli specialitása, és nem kizárt a jogutódlás lehetősége, úgy ebben az adott társaság tagjai törvény erejénél fogva elsőbbséget élveznének, még ha egyébként törvényes öröklés alkalmával csak egy olyan parentélában foglalnának helyet, amelynek a tagjai nem örökölnek; ezzel is eltérítve a cégbeli részesedésen kívüli vagyontárgyakra irányadó öröklési jogi szabályokat. A fogalom jogszabályi szintű megalkotásának akkor van értelme, ha ahhoz további joghatás is füződne, ilyen egyrészt a speciális jogutódlás bevezetése, valamint például adókedvezmény meghatározása.

Az öröklési szerződés egyszerre magán viseli a tartási, illetve életjáradéki szerződések, valamint a végrendeletek stílusjegyeit, amelynek tárgya lehet az üzletrész, a részvény, stb. az öröklés és az átruházás határán elhelyezkedő jogintézmény, ezért mindkét terület szabályozását figyelembe kell venni. Ezek a szerződések alkalmasak arra, hogy a szerződéskötéshez viszonyítva változatlan körülmények fennállta esetére egyrészt biztosítsák a társasági részesedésben való jogutódlást, másrészt a leendő örökhagyó ellátásbeli igényeinek kielégítését. Az öröklési szerződések alkalmazásánál először mindig meg kell nézni a létesítő okiratot, hogy korlátozza-e vagy kizárja a részesedésszerzést ezen a jogcímen, ha lehetővé teszi, minden további nélkül köthetők ilyen szerződések, ha nem teszi lehetővé, vagy más utat keres az igények kielégítésére és a társasági részesedésének átörökítésére, vagy a társasági szerződést módosítja a legfőbb szerv. Ezzel a jogintézménnyel megfelelő felkészülési lehetőség áll rendelkezésre a társaságbeli pozícióbeli jogutódlás biztosítására.

A hagyatéki tartozásokért, ezek között említve bizonyos esetekben a társasági részesedéssel összefüggő kötelezettségeket, való felelősség és a társasági jog legeklatánsabb példája a közkereseti társaságoknál, illetve a megfelelő alkalmazás 
folytán a betéti társaságoknál jelenik meg, amikor a törvényhely maga utal ezeknek a szabályoknak a figyelembe vételére, nem szabad azonban figyelmen kívül hagyni a Hetedik Könyvbeli szabályok generális jellemzőjét, miszerint bármely öröklés esetén helyt kell állnia a tartozási sorrendbe illeszkedő kötelezettségért.

$\mathrm{Az}$ öröklési rendeletnek megfelelö szabályozás jogrendszerünkbe való beépítését, a már jelzetteknek megfelelően, a rendeletnek hazánkra is kötelező jellege indokolta. Megalkotásának szükségességére a preambulum adja meg a választ, mivel tekintettel kell lenni az egyre gyakoribb, határokon átnyúló öröklési elemet tartalmazó jogviszonyokra, ráadásul ezek a hagyatékok egyre nagyobb értéket képviselnek. A jogszabály e jogviszonyok lehető legteljesebb spektrumát igyekszik lefedni, ami kollíziós és nemzetközi polgári eljárásjogi szempontból csak lehetséges, egyúttal próbált figyelemmel lenni a tagállamok jogaiban előforduló minden, egymáshoz képest rendkívül eltérő jellegü, öröklési jogi szempontból szóba jövő lehetséges helyzetre, ebből került kiemelésre néhány momentum, ami megítélésem szerint a magyar öröklési jog vonatkozásában is szerephez juthat. Az öröklési rendelet alapjában véve nem sok változást hozott a magyar jogéletbe, a magyar szabályozás megfelel az európai követelményeknek. Ez betudható annak is, hogy az öröklési rendelet végleges szövege már elkészült a Ptk. kodifikációs munkálatai alatt, így azt figyelembe vették. A rendeletnek való teljes körü megfelelés érdekében szükségessé vált bizonyos, javarészt eljárási szabályok megalkotása, amelyekre sor is került. Habár a rendelet tárgyi hatálya nem tér ki bizonyos társasági jogi kérdésekre, még akkor sem, ha az egyébként az öröklés szempontjából relevanciával is bírna, a rendelet hatálya alól kizáró szabályok vizsgálata szükséges e szabályok terjedelmének a meghatározásához, erre tettem kísérletet. 


\section{Irodalomjegyzék}

1. Adorján 2000. = Adorján Lívia: A hagyatéki vagyon változásának és az özvegyi jog érvényesülésének gyakorlati problémái. In: Magyar Jog 2000/6.

2. Adorján 1999. = Adorján Lívia: Társasági részesedések - értékpapírok a hagyatékban. In: Gazdaság és Jog 1999/11.

3. 1871-es tervezet = Általános Magánjogi Törvénykönyv Tervezete Magyarország számára. I. Közlemény Általános Rész. Pest, 1871.

4. Anka 1999. = Anka Tibor: Különleges vagyontárgyak a hagyatékban. In: A Polgári Jogi Tudományos Diákkör évkönyve 1998-1999. tanév, Eötvös Loránd Tudományegyetem Állam- és Jogtudományi Diákkör, Budapest, 1999.

5. Anka 2013. = Anka Tibor: Öröklés az új Ptk.-ban. In: Grad-Gyenge Anikó (szerk.): Egy új korszak hajnalán, Károli Gáspár Református Egyetem Állam- és Jogtudományi Kar, Budapest, 2013.

6. Anka 2014a. = Anka Tibor: Öröklési jog - Hagyatéki eljárás. 2. hatályosított kiadás, HVG-ORAC Lap- és Könyvkiadó Kft., Budapest, 2014.

7. Anka 2014b. = Anka Tibor: Az öröklés joghatásai. In: Osztovits András (szerk.): A Polgári Törvénykönyvről szóló 2013. évi V. törvény és a kapcsolódó jogszabályok nagykommentárja IV. kötet, Opten Informatikai Kft., Budapest, 2014.

8. Anka 2014c. = Anka Tibor: Öröklési szerződés. In: Osztovits András (szerk.): A Polgári Törvénykönyvről szóló 2013. évi V. törvény és a kapcsolódó jogszabályok nagykommentárja IV. kötet, Opten Informatikai Kft., Budapest, 2014.

9. Anka 2006. = Anka Tibor: Szokatlan vagyontárgyak a hagyatékban. In: Közjegyzők Közlönye 2006/6.

10. Apathy = Apathy, Peter: Erbrecht. In: Riedler, Andreas (szerk.): Zivilrecht VII, 5. átdolgozott kiadás, LexisNexis Verlag, Wien, 2015.

11. Auer = Auer Ádám: Gondolatok a Ptk. III. könyvének diszpozitív szabályozásáról. In: Opuscula Civilia 2016/3.

12. Magyar nyelvü céhlevelek $=$ Az Mester Emberek jó rendtartása, Magyar nyelvü céhlevelek (1525-1682). MTA Néprajzi Kutatóintézet, Budapest, 2000. 
13. Barta 2016a. = Barta Judit: Gondolati kalandozások a személyegyesítő társaságok tagjának halála okán felmerülő kérdések körül. In: Miskolci konferenciák 2015 Az új Ptk. öröklési jogi szabályai - Tapasztalatok és kritikák, Novotni Alapítvány a Magánjog Fejlesztéséért, Miskolc, 2016.

14. Barta 2016b. = Barta Judit: VII. fejezet Korlátolt felelősségü társaság. In: Barta Judit - Harsányi Gyöngyi - Majoros Tünde - Ujváriné Antal Edit: Gazdasági társaságok a Polgári Törvénykönyvben, Patrocinium Kiadó, Budapest, 2016.

15. Barta 2012. = Barta Judit: Néhány elméleti, valamint a gyakorlatból fakadó észrevétel a korlátolt felelősségü társaság szövegtervezetéhez. In: Miskolci konferenciák 2011 Javítandó és jobbítható elemek a Ptk. kodifikációjában, Novotni Alapítvány a Magánjog Fejlesztéséért, Miskolc, 2012.

16. Barta 2017. = Barta Judit: A tag halálának joghatása a gazdasági társaságok működésére. In: Adó-kódex Cégvezetők ABC-je 2017/8.

17. Barta 2003. = Barta Judit: XIV. fejezet A vízgazdálkodási társulat. In: Barta Judit - Fazekas Judit - Harsányi Gyöngyi - Miskolczi Bodnár Péter - Ujváriné Antal Edit: Speciális társaságok - A társaságok különös formái, KJK-KERSZÖV Jogi és Üzleti Kiadó Kft., Budapest, 2003.

18. Barta - Kovács = Barta Judit - Kovács István: A speciális társaságok iratmintatára. KJK-Kerszöv Jogi és Üzleti Kiadó Kft., Budapest, 2000.

19. Barzó = Barzó Tímea: Cselekvőképtelen, illetve korlátozottan cselekvőképes személyek részvétele a gazdasági társaságokban. In: Jogi személyek az új Polgári Törvénykönyvben, Novotni Alapítvány a Magánjog Fejlesztéséért, Miskolc, 2013.

20. Benke $=$ Benke József: A jogalap nélküli gazdagodás vagyonjogi jelentősége és generálklauzulája. In: Polgári Jog 2016/7-8.

21. Besenyei 2009. = Besenyei Lajos: A gazdasági társaságokról szóló törvény egy polgári jogász szemszögéből. In: Acta Conventus de Iure Civili. Tomus X., Lectum Kiadó, Szeged, 2009.

22. Besenyei 2004. = Besenyei Lajos: Az öröklési jogunk vitatható kérdései. In: Tanulmányok dr. Molnár Imre egyetemi tanár 70. születésnapjára, Szeged, 2004.

23. Besenyei 2002. = Besenyei Lajos: A társasági jog és az örökjog kapcsolatáról. In: Gazdaság és Jog 2002/12. 
24. Bíró (szerk.) = Bíró György (szerk.) - Barzó Tímea - Juhász Ágnes - Lenkovics Barnabás - Pusztahelyi Réka: Általános tanok és személyek joga. Novotni Kiadó, Miskolc, 2014.

25. Blutman = Blutman László: Az Európai Unió joga a gyakorlatban. 2. átdolgozott kiadás, HVG-ORAC Lap- és Könyvkiadó Kft., Budapest, 2013.

26. Bobvos - Hegyes = Bobvos Pál - Hegyes Péter István: A földforgalom $\mathrm{s}$ földhasználat alapintézményei. SZTE ÁJK - JATEPress, Szeged, 2015.

27. Bodor $=$ Bodor Mária: A vagyonrendezési eljárás egyes kérdéseiről I. In: Céghírnök 2006/1.

28. Bókai = Bókai Judit: Az örökös felelőssége, különös tekintettel a túlterhelt hagyaték kérdésére. In: Közjegyzők Közlönye 2001/7-8.

29. Boóc $=$ Boóc Ádám: A közkereseti társaság. In: Sárközy Tamás (szerk.): Polgári jog - A jogi személy, 2. átdolgozott, bővített kiadás, HVG-ORAC Lap- és Könyvkiadó Kft., Budapest, 2014.

30. Boros = Boros Anita: OECD Guidelines on Corporate Governance of StateOwned Enterprises from Hungarian State-Owned Enterprises' Point of View. In: Pro Publico Bono - Public Administration 2017 Special Edition 1.

31. Brünner - Pasrucker $=$ Brünner, Georg - Pasrucker, Christoph: Die GmbH von der Gründung bis zur Auflösung. 2. Auflage, dbv-Verlag, Graz - Wien, 2016.

32. Burandt - Rojahn $=$ Burandt, Wolfgang - Rojahn, Dieter: Erbrecht. 2. átdolgozott kiadás, Beck, München, 2014.

33. Complex CD jogtár 1959. évi IV. törvényhez írt kommentár

34. Csák = Csák Csilla (szerk.): Agrárjog. Novotni Kiadó, Miskolc, 2006.

35. Csehi 2013. = Csehi Zoltán: A Polgári Törvénykönyv időfogalma és magánjogunk időfelfogása. Pázmány Press, Budapest, 2013.

36. Csehi 2014. = Csehi Zoltán: A kereskedelmi (gazdasági) társaságok szabályozásának megújulásáról az új Polgári Törvénykönyvben. In: MiskolcziBodnár Péter - Grad-Gyenge Anikó (szerk.): „Megújulás a jogi személyek szabályozásában” - tanulmányok az új Ptk. köréből, Károli Gáspár Református Egyetem Állam- és Jogtudományi Kar, Budapest, 2014.

37. Csehi 2016. = Csehi Zoltán: Az új Ptk. jogi személy szabályozásának a kógenciájáról és diszpozitivitásáról. In: Polgári Jog 2016/3.

38. Csizmazia $=$ Csizmazia Norbert: Az új holland öröklési jog. In: Polgári Jogi Kodifikáció 2003/2. 
39. Csüri = Csűri Éva Katalin: A társasági részesedések a házassági vagyonjogban. HVG-ORAC Lap- és Könyvkiadó Kft., Budapest, 2006.

40. Diwisch - Voithofer - Weiss $=$ Diwisch, Sandra - Voithofer, Peter - Weiss, Christoph R.: The 'Shadow of Succession' - A Non-Parametric Matching Approach. In: Discussion Papers SFB International Tax Coordination, 13. SFB International Tax Coordination, WU Vienna University of Economics and Business, Vienna. (Available in ePubWU: February 2006) (Utolsó letöltés ideje: 2016. 09. 12.)

41. Doralt - Nowotny - Kalss $=$ Doralt, Peter - Nowotny, Christian - Kalss, Susanne: Kommentar zum Aktiengesetz. Band I $\S \S 1-136,2$. Auflage, Linde Verlag, Wien, 2012.

42. Dzsula-kommentár = Dzsula Mariann: Kommentár az egyes jogi személyek átalakulásáról, egyesüléséről, szétválásáról szóló 2013. évi CLXXVI. törvényhez. http://uj.jogtar.hu (utolsó letöltés ideje: 2017. december 31.)

43. Dzsula 2014a. = Dzsula Mariann: Miért kógens a diszpozitív? I. In: Céghírnök $2014 / 2$.

44. Dzsula 2014b. = Dzsula Mariann: Miért kógens a diszpozitív? III. In: Céghírnök 2014/4.

45. Dzsula 2014c. = Dzsula Mariann: Összefoglaló a „Kógencia és diszpozitivitás az új Ptk. jogi személyekről szóló könyvében" címü vitaanyagban felvetett kérdésekben a Civilisztikai Kollégiumvezetők 2014. május 21-23. napjain tartott tanácskozása által kialakított álláspontokról. In: Kúriai Határozatok 2014/9.

46. Az erdőbirtokossági társulat megalakulása. In: Céghírnök 1994/10.

47. Fábián 2014. = Fábián Ferenc: Előadásvázlatok az öröklési jog köréből. 2. átdolgozott és kibővített kiadás, Patrocinium, Budapest, 2014.

48. Fábián 2015. = Fábián Ferenc: 77. Az öröklés általános szabályai, kiesés az öröklésből, érdemtelenség, lemondás az öröklésről. In: Sándor István (szerk.): Polgári jog III. Az öröklési jog, a családi jog - Jogi szakvizsga könyvek, Patrocinium Kiadó, Budapest, 2015.

49. Fabó 2014a. = Fabó Tibor: Hagyatéki tartozások és kielégítésük. In: Osztovits András (szerk.): A Polgári Törvénykönyvről szóló 2013. évi V. törvény és a kapcsolódó jogszabályok nagykommentárja IV. kötet, Opten Informatikai Kft., Budapest, 2014. 
50. Fabó 2014b. = Fabó Tibor: Kötelesrész. In: Osztovits András (szerk.): A Polgári Törvénykönyvröl szóló 2013. évi V. törvény és a kapcsolódó jogszabályok nagykommentárja IV. kötet, Opten Informatikai Kft., Budapest, 2014.

51. Fabó 2014c. = Fabó Tibor: Öröklés. In: Osztovits András (szerk.): A Polgári Törvénykönyvröl szóló 2013. évi V. törvény és a kapcsolódó jogszabályok nagykommentárja IV. kötet, Opten Informatikai Kft., Budapest, 2014.

52. Farkas $=$ Farkas Csaba: Az üzletrész felosztása. In: Acta Conventus De Iure Civili Tomus X., Lectum Kiadó, Szeged, 2009.

53. Fazekas (szerk.) = Fazekas Mariann (szerk.): Közigazgatási jog - Általános rész I. ELTE Eötvös Kiadó, Budapest, 2014.

54. Fézer et al. 2007. = Fézer Tamás - Károlyi Géza - Petkó Mihály - Törő Emese: A gazdasági szféra alanyai - a gazdasági társaságok. Kossuth Egyetemi Kiadó, Debrecen, 2007.

55. Fézer et al. 2012. = Fézer Tamás - Károlyi Géza - Petkó Mihály - Törő Emese: A kereskedelmi jog alanyai - Cégek és civil szervezetek joga. Kapitális Nyomdaipari Kft., Debrecen, 2012.

56. Fézer et al. 2014. = Fézer Tamás - Károlyi Géza - Petkó Mihály - Törő Emese: Jogi személyek a gazdasági forgalomban. Kapitális Nyomdaipari Kft., Debrecen, 2014.

57. Fiedler $=$ Fiedler Laura Ágnes: Gondolatok a kötelesrészről... (Múlt - jelen jövő). In: Magyar Jog 2016/7-8.

58. Fischer-Czermak $=$ Fischer-Czermak, Constanze: Artikel $32-$ Kommorienten . In: Deixler-Hübner, Astrid - Schauer, Martin (szerk.): Kommentar zur EUErbrechtsverordnung, MANZ'sche Verlags- und Universitätsbuchhandlung, Wien, 2015.

59. Frimston = Frimston, Richard: Artikel 3. In: Bergquist, Ulf et al.: EUErbrechtsverordnung Kommentar, Verlag Dr. Otto Schmidt, Köln, 2015.

60. Gadó = Gadó Gábor: A dolgozói részvény és az osztalékjog szabályozásáról II. In: Céghírnök 2011/4.

61. Gál 2014. = Gál Judit: Az átalakulási szabályok új Ptk.-val összefüggő változásai. In: Céghírnök 2014/4.

62. Gál 2015. = Gál Judit (szerk.): Társasági és cégjogi iratmintatár. 3. átdolgozott kiadás, HVG-ORAC Lap- és Könyvkiadó Kft., Budapest, 2015.

63. Gál 2002. = Gál Judit: A társasági vagyonrész öröklése. In: Céghírnök 2002/3. 
64. Gál 2010. = Gál Judit: Újdonságok az egyéni cégek szabályozásában. In: Gazdaság és Jog 2010/11.

65. Gál - Adorján $=$ Gál Judit - Adorján Csaba: A gazdasági társaságok átalakulása. HVG-ORAC Lap- és Könyvkiadó Kft., Budapest, 2010.

66. Gellért = Gellért György: Az öröklési szerződés. KJK-KERSZÖV Jogi és Üzleti Kiadó Kft., Budapest, 2001.

67. Gerendás $=$ Gerendás Ernő: Adatok a budai és pesti céhek életéhez, különös tekintettel a Fővárosi Könyvtár céhirataira. Különlenyomat a Fővárosi Könyvtár évkönyve X. kötetéből. In: Tanulmányok XVII, Fővárosi Könyvtár, Budapest, 1940.

68. Gombos = Gombos Katalin: A jog érvényesülésének térsége az Európai Unióban. Wolters Kluwer Kft., Budapest, 2014.

69. Gothárdi = Gothárdi Enikő: Az általános joghatóság szabályozása az Európai Unió öröklési rendeletében. In: Magyar Jog 2015/9.

70. Graisy = Graisy, Johanna: Vererbung von GmbH-Geschäftsanteilen Praxisleitfaden $\mathrm{zu}$ den erbrechtlichen und gesellschaftsrechtlichen Gestaltungsmitteln. Verlag Österreich GmbH, Wien, 2016.

71. Guggenberger = Guggenberger, Bernd: Unternehmensübergabe an nächste Generation. In: Czernich, Dietmar - Guggenberger, Bernd - Schwarz, Manfred (szerk.): Handbuch des österreichischen Familienunternehmens. LexisNexis Verlag ARD ORAC GmbH \& Co. KG, Wien, 2005.

72. Gummert = Gummert, Hans: 1 . Teil. Die Kommanditgesellschaft. In: Gummert, Hans - Weipert, Lutz (szerk.): Münchener Handbuch des Gesellschaftsrechts, Band 2., 4. neubearbeitete Auflage, Verlag C. H. Beck, München, 2014.

73. Gyekiczky = Gyekiczky Tamás: Az európai „öröklési”rendeletről. In: Európai Jog 2014/2.

74. Halász $=$ Halász Péter: Praktikus gondolatok a hagyatéki vagyontervezés témaköréhez. In: Mándoki István (szerk.): A hagyatéki vagyontervezés - Estate Planning, Studia Notarialia Hungarica Tom. XVII., Közjegyzői Akadémia Kiadó, Budapest, 2015.

75. Hamza - Sajó = Hamza Gábor - Sajó András: Az együtt elhalás néhány jogi kérdése. In: Magyar Jog 1976/3. 
76. Hajnóczy = Hajnóczy Iván: A céhek életéből. XV. és XVI. századbeli céhszabályok. Lampel R. (Wodianer F. és fiai) Rt., Franklin Társulat Nyomdája, Budapest, é. n.

77. Harsányi 2003. = Harsányi Gyöngyi: XV. fejezet Az erdőbirtokossági társulat. In: Barta Judit - Fazekas Judit - Harsányi Gyöngyi - Miskolczi Bodnár Péter Ujváriné Antal Edit: Speciális társaságok - A társaságok különös formái, KJKKERSZÖV Jogi és Üzleti Kiadó Kft., Budapest, 2003.

78. Harsányi 2015. = Harsányi Gyöngyi: Az értékpapírjog szabályozásának fejlődése az elmúlt két évtizedben. In: Miskolci konferenciák 2013, In memoriam Novotni Zoltán - Emlékkönyv Novotni Zoltán professzor halálának 20. évfordulója alkalmából, Novotni Alapítvány, Miskolc, 2015.

79. Harsányi 2010. = Harsányi Gyöngyi: A magyar értékpapírjog alapjai. Novotni Kiadó, Miskolc, 2010.

80. Harsányi 2016. = Harsányi Gyöngyi: VIII. fejezet Részvénytársaság. In: Barta Judit - Harsányi Gyöngyi - Majoros Tünde - Ujváriné Antal Edit: Gazdasági társaságok a Polgári Törvénykönyvben, Patrocinium Kiadó, Budapest, 2016.

81. Harsányi - Ujváriné - Miskolczi Bodnár = Harsányi Gyöngyi - Ujvári Andorné - Miskolczi Bodnár Péter: A jogutódlás mint sajátos szerződést módosító jogi tény a társaságokban. In: Magyar Jog 1991/4.

82. Havasi = Havasi Bálint: Halál és eltűnés. In: Közjegyzők Közlönye 2011/6.

83. Homoki-Nagy = Homoki-Nagy Mária: A magyar magánjogi kodifikáció első lépései. In: Szabó András emlékkönyv. Acta Universitatis Szegediensis de Attila József Nominatae, Acta Juridica et Politica, LIII. Szeged, 1998.

84. Horváth 2004. = Horváth Attila: Az első magyar kereskedelmi társaságokról szóló törvény. In: Jogtörténeti Szemle 2004/4.

85. Horváth 2006. = Horváth Attila: A magyar magánjog történetének alapjai. Gondolat Kiadó, Budapest, 2006.

86. Horváth 2003. = Horváth Attila: Széchenyi István részvénytársaság-alapításai. In: Jogtörténeti Szemle 2003/2.

87. 1914-es tervezet indokolása = Indokolás a Polgári Törvénykönyv törvényjavaslatához. I. kötet Bevezetés. Személyi és családi jog. Grill Károly Könyvkiadóvállalata, Budapest, 1914.

88. Jancsó = Jancsó György: A magyar házassági és házastársi öröklési jog. Politzer Zsigmond és fia kiadása, Budapest, 1901. 
89. Jójárt = Jójárt Eszter: Javaslat a tartási és életjáradéki szerződés jogi szabályozásának változtatására. In: Polgári Jogi Kodifikáció 2007/3.

90. Kalss 2015a. = Kalss, Susanne: Überlegungen zur Gestaltung der Unternehmensrechtsnachfolge im Zuge der laufenden Erbrechtsreform. In: Österreichische Notariatszeitung 2015/2.

91. Kalss 2015b. = Kalss, Susanne: Die Vererbung von Aktien. In: Journal für Erbrecht und Vermögensnachfolge 2015/4.

92. Kalss - Nowotny - Schauer $=$ Kalss, Susanne - Nowotny, Christian - Schauer, Martin: Österreichisches Gesellschaftsrecht. Manzsche Verlags- und Universitätsbuchhandlung, Wien, 2008.

93. Kalss - Probst $=$ Kalss, Susanne - Probst, Stephan: Familienunternehmen. Manzsche Verlags- und Universitätsbuchhandlung, Wien, 2013.

94. Károlyi = Károlyi Géza: Az egyszemélyes társaságokról. In: Jogtudományi Közlöny 1999/9.

95. Kelemen = Kelemen Dániel: Az angol társasági jog fejlődése. In: Jura 2006/1.

96. Kisfaludi 2014a.= Kisfaludi András: Harmadik Könyv Első Rész. In: Vékás Lajos - Gárdos Péter (szerk.): Kommentár a Polgári Törvénykönyvhöz I. kötet, Wolters Kluwer Kft., Budapest, 2014.

97. Kisfaludi 2014b. = Kisfaludi András: Harmadik Könyv Harmadik Rész. In: Vékás Lajos - Gárdos Péter (szerk.): Kommentár a Polgári Törvénykönyvhöz I. kötet, Wolters Kluwer Kft., Budapest, 2014.

98. Kisfaludi 1991. = Kisfaludi András: Társasági tagsági jogok a hagyatékban. In: Magyar Jog 1991/3.

99. Kisfaludi - Szabó = Kisfaludi András - Szabó Marianna (szerk.): A gazdasági társaságok nagy kézikönyve. Complex Kiadó Jogi és Üzleti Tartalomszolgáltató Kft., Budapest, 2008.

100. Koday $=$ Koday Zsuzsanna: A társasági jog néhány öröklési jogi vonatkozása kft.-nél. In: Gazdaság és Jog 2001/6.

101. Komáromi - Pázmándi = Komáromi Gábor - Pázmándi Kinga: A korlátolt felelősségü társaság. In: Sárközy Tamás (szerk.), Az új Ptk. magyarázata II/VI. A jogi személy, 2. átdolgozott, bővített kiadás, HVG-ORAC Lap- és Könyvkiadó Kft., Budapest, 2014. 
102. Köhler $=$ Köhler, Andreas: Artikel $32-$ Kommorienten. In: Kroiß, Ludwig et al. (szerk.): Nachfolgerecht - Erbrechtliche Spezialgesetze, Nomos Verlagsgesellschaft, Baden-Baden, 2015.

103. Körös - Makay $=$ Körös András - Makai Katalin: A jogképesség. In: Wellmann György (szerk.): Polgári jog - Bevezető és Záró Rendelkezések, Az ember mint jogalany, Öröklési jog, 2. átdolgozott, bővített kiadás, HVG-ORAC Lap- és Könyvkiadó Kft., Budapest, 2014.

104. Kőrösy = Körösy Judit: Kommentár az egyéni vállalkozóról és az egyéni cégről szóló 2009. évi CXV. törvényhez. http://uj.jogtar.hu (2016. május 16-i letöltés)

105. Kovács G. = Kovács Gergely: Gondolatok a hagyatéki tervezési céllal létrehozott társaságokról és alapítványokról. In: Mándoki István (szerk.): A hagyatéki vagyontervezés - Estate Planning, Studia Notarialia Hungarica Tom. XVII., Közjegyzői Akadémia Kiadó, Budapest, 2015.

106. Kovács I. = Kovács István: Koncesszió - koncessziós szerződés. In: Gazdaság és Jog 1997/12.

107. Kovács P. = Kovács Péter: Nemzetközi közjog. 2. átdolgozott és bővített kiadás, Osiris Kiadó, Budapest, 2011.

108. Kreiczer-Levy $=$ Kreiczer-Levy, Shelly: The mandatory nature of inheritance. In: The American Journal of Jurisprudence Vol. 53. 2008.

109. Kristó $=$ Kristó Gyula - Barta János - Gergely Jenő: Magyarország története elöidőktől 2000-ig. Pannonica Kiadó, Budapest, 2002.

110. Kuncz 1937a. = Kuncz Ödön: A magyar kereskedelmi- és váltójog I. rész 1. fele: A kereskedő vállalata, Grill Károly könyvkiadóvállalata, Budapest, 1937.

111. Kuncz 1937b. = Kuncz Ödön: A magyar kereskedelmi- és váltójog I. rész 2. fele: Kereskedelmi társaságok, Grill Károly könyvkiadóvállalata, Budapest, 1937.

112. Kurucz 2007a. = Kurucz Mihály: Az agrárjog tárgya, fogalma, alapelvei és rendszere. In: Agrár- és Környezetjog 2007/2.

113. Kurucz 2015. = Kurucz Mihály: Gondolatok a magyar földforgalmi törvény uniós jogi feszültségpontjainak kérdéseiről. In: Szalma József (szerk.): A Magyar Tudomány Napja a Délvidéken 2014., Vajdasági Magyar Tudományos Társaság, Újvidék, 2015. 
114. Kurucz 2007b. = Kurucz Mihály: A magyar termőföldforgalom szabályozásának mai rendszeréről és megújításának alapjairól. In: Agrár- és Környezetjog 2007/3.

115. Lábady = Lábady Tamás: A magánjog általános tana, Szent István Társulat, Budapest, 2013.

116. Lagarde $=$ Lagarde, Paul: Artikel $32-$ Kommorienten. In: Bergquist, Ulf et al.: EU-Erbrechtsverordnung Kommentar, Verlag Dr. Otto Schmidt, Köln, 2015.

117. LeMar = LeMar, Bernd: Generations- und Führungswechsel im Familienunternehmen. 2. Auflage, Springer Fachmedien, Wiesbaden, 2014.

118. Lenkovics = Lenkovics Barnabás: A jogképesség kezdete és megszűnése. In: Vékás Lajos - Gárdos Péter (szerk.): Kommentár a Polgári Törvénykönyvhöz I. kötet, Wolters Kluwer Kft., Budapest, 2014.

119. Leszkoven = Leszkoven László: A kötelesrész kielégítése és a szerencseszerződések - Gondolatok az új Polgári Törvénykönyv 7:80. § (4) bekezdésének ún. „kétéves szabályáról”. In: Miskolci konferenciák 2015, Az új Ptk. öröklési jogi szabályai, Tapasztalatok és kritikák, Novotni Alapítvány, Miskolc, 2016.

120. Lőrinczi = Lőrinczi Gyula: A korlátolt felelősségü társaság mint „tolómérő”. In: Gazdaság és Jog 2012/7-8.

121. Ludwig = Ludwig, Ingo: Az öröklési kollíziós jog európai jog összehasonlító vizsgálata. In: Közjegyzők Közlönye 2004/7-8.

122. Mádl - Vékás = Mádl Ferenc - Vékás Lajos: Nemzetközi magánjog és nemzetközi gazdasági kapcsolatok joga. 8. átdolgozott kiadás, ELTE Eötvös Kiadó, Budapest, 2015.

123. 1900-as tervezet $=$ A magyar általános Polgári Törvénykönyv tervezete. Első szöveg. Grill Károly cs. és kir. udv. könyvkereskedése, Budapest, 1900.

124. 1900-as tervezet bírálata = A magyar általános Polgári Törvénykönyv tervezetének további tárgyalását előkészítő főelőadmány és a tervezetre bírálati anyag. I. kötet. Grill Károly cs. és kir. udvari könyvkereskedése, Budapest, 1904.

125. régi Ptk. indokolása $=\mathrm{A}$ Magyar Népköztársaság Polgári Törvénykönyve. Az 1959. évi IV. törvény és a törvény javaslatának miniszteri 
indokolása. Közzéteszi az Igazságügyi Minisztérium, Közgazdasági és Jogi Könyvkiadó, Budapest, 1960.

126. Metzinger $=$ Metzinger Péter: Diszpozitivitás és/vagy kogencia a magyar társasági jogban. In: Fontes Iuris 2015/3-4.

127. Mezey (szerk.) = Mezey Barna (szerk.): Magyar jogtörténet. Osiris Kiadó, Budapest, 2007.

128. Miskolczi Bodnár 2004. = Miskolczi Bodnár Péter: A kisvállalkozások forrásteremtését és különösen kockázati tőkével való támogatását segítő kezdeményezések az EU-ban és Magyarországon. In: Varsányi Judit (szerk.): Kis- és középvállalkozások az Európai Unió küszöbén, Széchenyi István Egyetem, Györ, 2004.

129. Miskolczi Bodnár 2016. = Miskolczi Bodnár Péter: Koncesszió. In: Barta Judit - Fazakas Zoltán - Harsányi Gyöngyi - Miskolczi Bodnár Péter - Szuchy Róbert - Ujváriné Antal Edit (Majoros Tünde szerk.): Kereskedelmi szerződések alapvető szabályai, 2. átdolgozott kiadás, Patrocinium Kiadó, Budapest, 2016.

130. Miskolczi Bodnár 2003. = IX. fejezet Miskolczi Bodnár Péter: A koncessziós társaság. In: Barta Judit - Fazekas Judit - Harsányi Gyöngyi Miskolczi Bodnár Péter - Ujváriné Antal Edit: Speciális társaságok - A társaságok különös formái, KJK-KERSZÖV Jogi és Üzleti Kiadó Kft., Budapest, 2003.

131. Mohai 2016a. = Mohai Máté: Felelősség és helytállási kötelezettség a társaságok jogában a Kereskedelmi Törvénytől az első társasági törvényünkig. In: Miskolci Jogi Szemle 2016/2.

132. Mohai 2016b. = Mohai Máté: A gazdasági társaságok tagjainak helytállási kötelezettségéről. In: Magyar Jog 2016/7-8.

133. Molnos - Szabó 2015a. = Molnos Dániel - Szabó Imre Gergely: Az elhunyt tag esete I. In: Céghírnök 2015/9.

134. Molnos - Szabó 2015b. = Molnos Dániel - Szabó Imre Gergely: Az elhunyt tag esete II. In: Céghírnök 2015/10.

135. Müller $=$ Müller, Jens-Oliver: Unternehmensübertragung zu Lebzeiten. In: Wegmann, Jürgen - Wiesehahn, Andreas (szerk.): Unternehmensnachfolge Praxishandbuch für Familienunternehmen, Springer Fachmedien, Wiesbaden, 2015. 
136. Müller-Lukoschek $=$ Müller-Lukoschek, Jutta: Die neue EUErbrechtsverordnung. 2. Auflage, zerb Verlag, Bonn, 2015.

137. Nagy Barna - Dúl = Nagy Barna Krisztina - Dúl János: Az öröklési szerződés szindikátusi szerződéskénti alkalmazhatósága a tárasági jogban, mint népességmegtartó tényező. In: Államtudományi Mühelytanulmányok 2017/19.

138. Nagy Cs. I. = Nagy Csongor István: Nemzetközi magánjog. 2. átdolgozott és bővített kiadás, HVG-ORAC Lap- és Könyvkiadó Kft., Budapest, 2012.

139. Nagy F. = Nagy Ferenc: A magyar kereskedelmi jog kézikönyve: különös tekintettel a bírói gyakorlatra és a külföldi törvényhozásokra. 2. kötet. Athenaeum, Budapest, 1913.

140. Neumayr = Neumayr, Matthias: Europäisches Nachlasszeugnis. In: Österreichisches Anwaltsblatt 2016/5.

141. Nochta 2014a. = Nochta Tibor: A betéti társaság. In: Osztovits András (szerk.): A Polgári Törvénykönyvröl szóló 2013. évi V. törvény és a kapcsolódó jogszabályok nagykommentárja I. kötet, Opten Informatikai Kft., Budapest, 2014.

142. Nochta 2014b. = Nochta Tibor: A közkereseti társaság. In: Osztovits András (szerk.): A Polgári Törvénykönyvről szóló 2013. évi V. törvény és a kapcsolódó jogszabályok nagykommentárja I. kötet, Opten Informatikai Kft., Budapest, 2014.

143. Nochta 2011. = Nochta Tibor: Társasági jog. Dialóg Campus Kiadó, Budapest-Pécs, 2011.

144. Nótári - Papp 2004. = Nótári Tamás - Papp Tekla: Az együtt elhalás problematikája a történetiség és az új Ptk. koncepciójának tükrében. In: Acta Universitatis Szegediensis Acta Juridica et Politica Tomus LXVI. Fasc. 16., Szeged, 2004.

145. Nótári - Papp 2013. = Nótári Tamás - Papp Tekla: Commorientes - on the problem of simultaneous death in the law of inheritance. In: Matters of relevance in economy, law, and studies in 2013 (Collection of Scientific Articles - International Scientific Practical Conference), Kauno Kolegija, Ekonomikos ir teises fakultetas, Kaunas, 2013.

146. Odersky = Odersky, Felix: Die Europäische Erbrechtsverordnung in der Gestaltungspraxis. In: notar 2013/1. 
147. Orosz 2014a. = Orosz Árpád: Kiesés az öröklésből. In: Orosz Árpád Weiss Emilia (szerk. Sáriné Simkó Ágnes): Öröklési jog - Anyagi jog, HVGORAC Lap- és Könyvkiadó Kft., Budapest, 2014.

148. Orosz 2014b. = Orosz Árpád: Öröklési jogunk az új Polgári Törvénykönyvben. In: Jogtudományi Közlöny 2014/6.

149. Orosz 2014c. = Orosz Árpád: Öröklési jog. In: Wellmann György (szerk.): Polgári jog - Bevezető és Záró Rendelkezések, Az ember mint jogalany, Öröklési jog, 2. átdolgozott, bővített kiadás, HVG-ORAC Lap- és Könyvkiadó Kft., Budapest, 2014.

150. Orosz K. = Orosz Katalin: A dolgozói részvényről. In: Céghírnök $1996 / 4$.

151. Osztovits $=$ Osztovits András: A kötelmek közös szabályai. In: Osztovits András (szerk.): A Polgári Törvénykönyvről szóló 2013. évi V. törvény és a kapcsolódó jogszabályok nagykommentárja III. kötet, Opten Informatikai Kft., Budapest, 2014.

152. Papp 2015. = Papp Tekla (szerk.): Atipikus szerződések. Opten Kft., Budapest, 2015.

153. Papp 2013. = Papp Tekla: Felelősségátvitel, felelősségáttörés - quo vadis ius societatum. In: Papp Tekla: Opuscula civilia - Magánjogi látlelet, Lectum Kiadó, Szeged, 2013.

154. Papp 2011a. = Papp Tekla: Gazdasági társasági formák Magyarországon - Elönyök és hátrányok rendszere. In: Acta Conventus De Iure Civili Tomus XIII., Lectum Kiadó, Szeged, 2011.

155. Papp 2010b. = Papp Tekla: A jogi személyiség nélküli gazdasági társaságok. In: Bodzási Balázs (szerk.): Ünnepi tanulmányok Balásházy Mária tiszteletére, Budapesti Corvinus Egyetem, Gazdasági Jogi Intézet, Budapest, 2010.

156. Papp 2006. = Papp Tekla: A koncesszió. Pólay Elemér Alapítvány, Szeged, 2006.

157. Papp 2011b. = Papp Tekla (szerk.): Társasági jog. Lectum Kiadó, Szeged, 2011.

158. Papp 2010a. = Papp Tekla: Társasági jogi jogalkotásunk rövid története, európai kitekintéssel. In: Nótári Tamás (szerk.): Ünnepi tanulmányok Sárközy Tamás 70. születésnapjára, Lectum Kiadó, Szeged, 2010. 
159. Papp 2014a. = Papp Tekla: A jogi személy átalakulása, egyesülése, szétválása és jogutód nélküli megszünése. In: Osztovits András (szerk.): A Polgári Törvénykönyvröl szóló 2013. évi V. törvény és a kapcsolódó jogszabályok nagykommentárja, I. kötet, Opten Informatikai Kft., Budapest, 2014.

160. Papp 2014b. = Papp Tekla: Vázlatos áttekintés a jogi személyröl az új Polgári Törvénykönyv apropóján. In: Pro Publico Bono Magyar Közigazgatás $2014 / 2$.

161. Papp 1993. = Papp Tekla: A német korlátolt felelősségü társaság felelősségi megoldásai az alapítási stádiumban. In: Magyar Jog 1993/10.

162. Pardy $=$ Pardy Balázs: Commorientes, vagyis a közös veszélyben elhunytak utáni öröklés kérdése. http://www.arsboni.hu/commorientes-vagyis-akozos-veszelyben-elhunytak-utani-orokles-kerdese.html (Utolsó letöltés ideje: 2015. 09. 02.)

163. Paulus $=$ Paulus, David: Das Schicksal von Gesellschaftsanteilen in internationalen Erbfällen. In: notar 2016/1.

164. Pázmándi 2014a. = Pázmándi Kinga: Az állam jogalanyisága a polgári jogi jogviszonyokban. In: Osztovits András (szerk.): A Polgári Törvénykönyvröl szóló 2013. évi V. törvény és a kapcsolódó jogszabályok nagykommentárja I. kötet, Opten Informatikai Kft., Budapest, 2014.

165. Pázmándi 2014b. = Pázmándi Kinga: A korlátolt felelősségü társaság. In: Osztovits András (szerk.): A Polgári Törvénykönyvröl szóló 2013. évi V. törvény és a kapcsolódó jogszabályok nagykommentárja I. kötet, Opten Informatikai Kft., Budapest, 2014.

166. Pázmándi 2015. = Pázmándi Kinga: Az üzletrész öröklésével (jogutódlásával) kapcsolatos Ptk.-beli szabályokról. In: Gazdaság és Jog 2015/5. 167. Pintér $=$ Pintér Attila: A tagsági és a részvényesi jogviszony keletkezéséről. In: Gazdaság és Jog 2015/6.

168. Pozsár $=$ Pozsár István: A Csongrád megyei céhek története. Bozó és Justin könyvnyomdája, Csongrád, 1912.

169. Probst $=$ Probst, Stefan: Erbrechtsnovelle 2014 aus dem Blickwinkel der Erhaltung der österreichischen Unternehmen. In: Die Wirtschaftstreuhänder 2014/5-6. 
170. Pusztahelyi $=$ Pusztahelyi Réka: Az öröklésből való kiesés. In: Barzó Tímea - Juhász Ágnes - Pusztahelyi Réka - Sápi Edit: Öröklési jog, Novotni Alapítvány, Miskolc, 2016.

171. Rauter $=$ Straube, Manfred - Ratka, Thomas - Rauter, Roman Alexander:

Wiener Kommentar zum GmbH-Gesetz. Manz Verlag, Wien, Stand 1. 12. 2014, rdb.at

172. Réti = Réti Mária: A kereskedelmi társaságok vagyonjogi szabályairól. In: Jogtudományi Közlöny 2005/3.

173. Sándor I. 2000. = Sándor István: A társasági jog előzményei az ókori jogokban. In: Jogtudományi Közlöny 2000/9.

174. Sándor I. 2005. = Sándor István: A társasági jog története NyugatEurópában. KJK-KERSZÖV Jogi és Üzleti Kiadó Kft., Budapest, 2005.

175. Sándor T. 2014a. = Sándor Tamás: Jegyzetek a részvénytársaság új szabályozásához. In: Gazdaság és Jog 2014/4.

176. Sándor T. 2014b. = Sándor Tamás: A részvény. In: Sárközy Tamás (szerk.): Polgári jog - A jogi személy, 2. átdolgozott, bővített kiadás, HVGORAC Lap- és Könyvkiadó Kft., Budapest, 2014.

177. Sápi 2016a. = Sápi Edit: Az öröklési jog alapvető fogalmai. In: Barzó Tímea - Juhász Ágnes - Pusztahelyi Réka - Sápi Edit: Öröklési jog, Novotni Alapítvány, Miskolc, 2016.

178. Sápi 2016b. = Sápi Edit: Második Rész - A végintézkedésen alapuló öröklés. In: Barzó Tímea - Juhász Ágnes - Pusztahelyi Réka - Sápi Edit: Öröklési jog, Novotni Alapítvány, Miskolc, 2016.

179. Sáriné Simkó = Sáriné Simkó Ágnes: Az egyéni vállalkozók és az egyéni cégek új szabályozása. In: Gazdaság és Jog 2010/1.

180. Sárközy 2014. = Sárközy Tamás (szerk.): Gazdasági társaságok Cégtörvény. HVG-ORAC Lap- és Könyvkiadó Kft., Budapest, 2014.

181. Sárközy 2015. = Sárközy Tamás: Még egyszer a Ptk. jogi személy könyve állítólagos diszpozitivitásáról. In: Gazdaság és Jog 2015/11.

182. Schauer - Motal - Reiter - Hofmair - Wöss: Schauer, Martin - Motal, Bernhard - Reiter, Sebastian - Hofmair, Marlene - Wöss, Sebastian: Erbrechtsreform: Paradigmenwechsel oder Window Dressing? In: Journal für Erbrecht und Vermögensnachfolge 2015/2. 
183. Schopper $=$ Schopper, Alexander: §76. In: Gruber, Michael - Harrer, Friedrich (szerk.): Gesetz über Gesellschaften mit beschränkter Haftung Kommentar, Linde Verlag, Wien, 2014.

184. http://www.successions-europe.eu/ (Utolsó letöltés ideje: 2017. december 31.)

185. Szalma = Szalma József: A kötelesrész, a végintézkedési szabadság és az öröklési szerződések az európai és a magyar magánjogban. In: Jogtudományi Közlöny 2016/7-8.

186. Szende $=$ Szende Péter Pál: Magyar hiteljog I. kötet. Kereskedelmi törvény és a reá közvetlenül vonatkozó joganyag. Grill Károly Könyvkiadóvállalata, Budapest, 1929.

187. Szikora 2014. = Szikora Veronika: A jogképesség. In: Osztovits András (szerk.): A Polgári Törvénykönyvről szóló 2013. évi V. törvény és a kapcsolódó jogszabályok nagykommentárja I. kötet, Opten Informatikai Kft., Budapest, 2014.

188. Szikora 2004. = Szikora Veronika: A polgári jogi társaság jelentősége a magyar és az osztrák jogban. In: Gazdaság és Jog 2004/7-8.

189. Szikora 2008. = Szikora Veronika: Társasági jogi reform Ausztriában vállalkozási törvény. In: Gazdaság és Jog 2008/12.

190. Szladits = Szladits Károly: A magyar magánjog vázlata I. rész. 4. átdolgozott kiadás, Grill Károly Könyvkiadóvállalata, Budapest, 1933.

191. Szőcs $=$ Szőcs Tibor: Az európai öröklési rendelet mint új kihívás. In: Közjegyzők Közlönye 2016/2.

192. Tarr $=$ Tarr György: Az öröklés kérdése a társasági jogban. In: Magyar Jog 1992/5.

193. Tóth $=$ Tóth Ildikó: A társasági jog és a hagyatéki eljárás. In: Céghírnök $1995 / 7$.

194. Tökey = Tökey Balázs: Az elővásárlási jog a Ptk.-ban. In: Polgári Jog $2016 / 6$.

195. Török G. 2011. = Török Gábor: Átalakulás, egyesülés, szétválás jogutód nélküli megszünés. In: Gazdaság és Jog, 2011/7-8.

196. Török G. 2014. = Török Gábor: A jogi személy átalakulása, egyesülése, szétválása és jogutód nélküli megszünése. In: Sárközy Tamás (szerk.): Polgári 
jog - A jogi személy, 2. átdolgozott, bővített kiadás, HVG-ORAC Lap- és Könyvkiadó Kft., Budapest, 2014.

197. Török T. 2011. = Török Tamás: Az üzletrész - és a részvényátruházás, átszállás korlátozása és kizárása. In: Gazdaság és Jog 2011/2.

198. Török T. 2015. = Török Tamás: Felelősség a társasági jogban. 2. átdolgozott és bővített kiadás. HVG-ORAC Lap- és Könyvkiadó Kft., Budapest, 2015.

199. Traar $=$ Traar, Thomas: Die EUErbVO. In: Barth, Peter - Pesendorfer, Ulrich (szerk.): Praxishandbuch des neuen Erbrechts, Linde Verlag, Wien, 2016. 200. t.t. = t.t.: Adalékok a közkereseti társaság jogához. In: Polgári Jog $1937 / 9$.

201. Ujváriné = Ujváriné Antal Edit: I. fejezet. A polgári jogi társaság. In: Barta Judit - Fazekas Judit - Harsányi Gyöngyi - Miskolczi Bodnár Péter Ujváriné Antal Edit: Speciális társaságok - A társaságok különös formái, KJKKERSZÖV Jogi és Üzleti Kiadó Kft., Budapest, 2003.

202. Vékás 2014a. = Vékás Lajos: A kötelmek közös szabályai. In: Vékás Lajos - Gárdos Péter (szerk.): Kommentár a Polgári Törvénykönyvhöz II. kötet, Wolters Kluwer Kft., Budapest, 2014.

203. Vékás 2014b. = Vékás Lajos: Öröklési jog. Eötvös József Könyvkiadó, Budapest, 2014.

204. Vékás 2013. = Vékás Lajos (szerk.): A Polgári Törvénykönyv magyarázatokkal. Complex Kiadó Jogi és Üzleti Tartalomszolgáltató Kft., Budapest, 2013.

205. Vékás - Weiss = Vékás Lajos - Weiss Emilia: Hetedik Könyv. In: Vékás Lajos - Gárdos Péter (szerk.): Kommentár a Polgári Törvénykönyvhöz II. kötet, Wolters Kluwer Kft., Budapest, 2014.

206. Vezekényi = Vezekényi Ursula: Részvénytársaság. In: Osztovits András (szerk.): A Polgári Törvénykönyvről szóló 2013. évi V. törvény és a kapcsolódó jogszabályok nagykommentárja I. kötet, Opten Informatikai Kft., Budapest, 2014.

207. Világhy $=$ Világhy Miklós: Öröklési jog. kézirat, Nemzeti Tankönyvkiadó, 1993. 
208. Villám = Villám Krisztián: A „megszokottként igazságosnak ítélethez való ragaszkodásról" - avagy rendelkezhet-e az örökhagyó végintézkedés útján haszonélvezet alapításáról? In: Közjegyzők Közlönye, 2016/3.

209. Visegrádi = Visegrádi Ágnes: Az örökös felelössége a hagyatéki tartozásokért. In: Magyar Jog 2015/7-8.

210. Weber $=$ Weber, Johannes: Artikel $32-$ Kommorienten. In: Dutta, Anatol - Weber, Johannes (szerk.): Internationales Erbrecht, Verlag C. H. Beck oHG, München, 2016.

211. Wellmann = Wellmann György: Egyes társasági jogi kérdésekröl. In: Közjegyzők Közlönye 2000/3.

212. Welser $=$ Welser, Rudolf: Grundriss des bürgerlichen Rechts Band II. Schuldrecht Allgemeiner Teil, Schuldrecht Besonderer Teil, Erbrecht. 13. neubearbeitete Auflage, Nachdruck, Manzsche Verlags- und Universitätsbuchhandlung, Wien, 2007.

213. $\underline{\text { http://www.vg.hu/kkv/optimistak-a-csaladi-cegek-475310 }}$ (Utolsó letöltés ideje: 2017 . december 31.)

214. Zeiss $=$ Zeiss, Hendrik: Unternehmensnachfolge bei Tod des Unternehmers. In: Wegmann, Jürgen - Wiesehahn, Andreas (szerk.): Unternehmensnachfolge - Praxishandbuch für Familienunternehmen, Springer Fachmedien, Wiesbaden, 2015. 


\section{Felhasznált jogszabályok, eseti döntések}

Magyarország Alaptörvénye (2011. április 25.)

Törvények, törvényerejü rendeletek

1827. évi 8. tc. a bizottsági rendszeres munkálatok további tárgyalása a legközelebbi országgyülésre halasztatik

1840. évi 16. tc. a kereskedőkről

1840. évi 18. tc. a közkeresetre összeálló társaságok jogviszonyairól

1875. évi XXXVII. tc. Kereskedelmi törvény

1876. évi XIV. tc. A közegészségügy rendezéséről

1877. évi XX. tc. A gyámsági és gondnoksági ügyek rendezéséről

1884. évi XVII. tc. Ipartörvény

1922. évi XII. tc. Az 1884. évi XVII. törvénycikkbe iktatott ipartörvény módosításáról

1930. évi V. tc. A korlátolt felelősségü társaságról és a csendes társaságokról

1959. évi IV. törvény a Polgári Törvénykönyvről

1979. évi 13. törvényerejü rendelet a nemzetközi magánjogról

1988. évi VI. törvény a gazdasági társaságokról

1990. évi XCIII. törvény az illetékekröl

1991. évi XVI. törvény a koncesszióról

1991. évi XXXIV. törvény a szerencsejáték szervezéséről

1993. évi XLVIII. törvény a bányászatról

1994. évi XLIX. törvény az erdőbirtokossági társulatról

1995. évi LVII. törvény a vízgazdálkodásról

1996. évi LXXXI. törvény a társasági adóról és az osztalékadóról

1999. évi XLIII. törvény a temetőkről és a temetkezésről

1997. évi CXLIV. törvény a gazdasági társaságokról 
1997. évi CLIV. törvény az egészségügyröl

2000. évi C. törvény a számvitelről

2004. évi XXXIV. törvény a kis- és középvállalkozásokról, fejlődésük támogatásáról

2006. év IV. törvény a gazdasági társaságokról

2006. évi V. törvény a cégnyilvánosságról, a bírósági cégeljárásról és a végelszámolásról

2007. évi LXXV. törvény a Magyar Könyvvizsgálói Kamaráról, a könyvvizsgálói tevékenységről, valamint a könyvvizsgálói közfelügyeletről

2007. évi CVI. törvény az állami vagyonról

2007. évi CXL. törvény a tőkeegyesítő társaságok határokon átnyúló egyesüléséről

2009. évi XXXVII. törvény az erdőről, az erdő védelméről és az erdőgazdálkodásról

2009. évi CXV. törvény az egyéni vállalkozóról és az egyéni cégről

2009. évi CXXII. törvény a köztulajdonban álló gazdasági társaságok takarékosabb müködéséről

2009. évi CXLIV. törvény a vízitársulatokról

2010. évi XXXVIII. törvény a hagyatéki eljárásról

2011. évi CXCV. törvény az államháztartásról

2011. évi CXCVI. törvény a nemzeti vagyonról

2012. évi CXXXIV. törvény a fiatalkorúak dohányzásának visszaszorításáról és a dohánytermékek kiskereskedelméröl

2013. évi V. törvény a Polgári Törvénykönyvröl

2013. évi CXXII. törvény a mező- és erdőgazdasági földek forgalmáról

2013. évi CLXXVI. törvény az egyes jogi személyek átalakulásáról, egyesüléséről, szétválásáról

2013. évi CLXXVII. törvény a Polgári Törvénykönyvröl szóló 2013. évi V. törvény hatálybalépésével összefüggő átmeneti és felhatalmazó rendelkezésekről

2015. évi LXXI. törvény a 650/2012/EU európai parlamenti és tanácsi rendelet 31. cikke szerinti megfeleltetési nemperes eljárásról, valamint egyes igazságügyi tárgyú törvénymódosításokról

2015. évi CXLIII. törvény a közbeszerzésekről 
2017. évi CXVIII. törvény a bírósági nemperes eljárásokban alkalmazandó szabályokról, valamint egyes bírósági nemperes eljárásokról

T/7971. számú törvényjavaslat indokolása

\section{$\underline{\text { Rendeletek }}$}

A földmüvelési-, ipar- és kereskedelemügyi, valamint az igazságügyi miniszter együttes rendelete ,a kereskedelmi czégjegyzékek berendezése és vezetése tárgyában”, In: Magyarországi rendeletek tára 1875., Vodianer F., Budapest, 1875. 523-533.

160/1995. (XII. 26.) Korm. r. a vízgazdálkodási társulatokról

326/2001. (XII. 30.) Korm. r. a családi gazdaságok létrehozásáról, nyilvántartásba vételéről, müködtetéséről, valamint kiemelt támogatásukról

1/1960. (IV. 13.) IM rendelet a holtnak nyilvánítási, valamint a halál tényének megállapításával kapcsolatos eljárásról

21/2006. (V. 18.) IM rendelet a cégbejegyzési eljárás és a cégnyilvántartás egyes kérdéseiről

24/2006. (V. 18.) IM rendelet az elektronikus cégbejegyzési eljárás és cégnyilvántartás egyes kérdéseiről

\section{Európai uniós jogszabályok, határozatok}

Az Európai Parlament és a Tanács 650/2012/EU rendelete (2012. július 4.) az öröklési ügyekre irányadó joghatóságról, az alkalmazandó jogról, az öröklési ügyekben hozott határozatok elismeréséről és végrehajtásáról, valamint az öröklési ügyekben kiállított közokiratok elfogadásáról és végrehajtásáról, valamint az európai öröklési bizonyítvány bevezetéséről

Az Európai Parlament és a Tanács 1287/2013/EU rendelete (2013. december 11.) a vállalkozások és a kis- és középvállalkozások versenyképességét segítő program (COSME) (2014-2020) létrehozásáról és az 1639/2006/EK határozat hatályon kívül helyezéséről

A Bizottság 1329/2014/EU végrehajtási rendelete (2014. december 9.) az öröklési ügyekre irányadó joghatóságról, az alkalmazandó jogról, az öröklési ügyekben hozott határozatok elismeréséről és végrehajtásáról, valamint az öröklési ügyekben kiállított közokiratok elfogadásáról és végrehajtásáról, valamint az európai öröklési bizonyítvány bevezetéséröl szóló 650/2012/EU európai parlamenti és tanácsi rendeletben említett formanyomtatványok meghatározásáról 
A Tanács határozata (2000. december 20.) a vállalkozásokra és különösen a kis- és középvállalkozásokra (KKV-kre) vonatkozó többéves programról (2001-töl 2005-ig)

Alkotmánybírósági határozatok

329/B/2001. AB határozat

219/B/2004. AB határozat

809/B/2004. AB határozat

\section{Közzétett eseti döntések}

BDT 2003. 767.

BDT 2005. 1107.

BDT 2005. 1127.

BDT 2005. 1288.

BDT 2006. 1330.

BDT 2007. 1581.

BDT 2008. 1768.

BDT 2010. 2258.

BDT 2011. 2385.

BDT 2012. 2827.

BDT 2013. 2392.

BDT 2013. 2975.

BDT 2014. 3086.

BDT 2014. 3164.

BDT 2014. 3166.

BDT 2015. 3400.

BDT 2016. 3551.

BDT 2016. 3553.

BH 1979. 181. 
BH 1980. 248.

BH 1980. 473.

BH 1981. 106.

BH 1981. 407.

BH 1983. 70.

BH 1988. 230.

BH 1988. 401.

BH 1988. 402.

BH 1990. 300.

BH 1990. 338.

BH 1991. 20.

BH 1993. 428.

BH 1993. 761.

BH 1995. 343.

BH 1996. 152.

BH 1996. 362.

BH 1996. 367.

BH 1996. 534.

BH 1997. 82.

BH 1998. 438.

BH 2000. 105.

BH 2001. 475.

BH 2002. 14.

BH 2004. 113.

BH 2004. 373.

BH 2005. 176.

BH 2006. 51. 
BH 2006. 212.

BH 2010. 275.

BH 2012. 170.

BH 2013. 130.

BH 2014. 306.

BH 2016. 62.

Debreceni Ítélőtábla Pf. II. 20.644/2015/7.

EBH 2001. 541.

EBH 2003. 884.

EBH 2004. 1024.

EBH 2005. 1212.

EBH 2005. 1213.

Fővárosi Ítélőtábla 13. Gf. 43.019/2010/2.

Fővárosi Ítélőtábla 10. Cgf. 45.071/2010/2.

Fővárosi Ítélőtábla 6. Pf. 20.767/2011/5. (FIT-H-PJ-2011-1289.)

Fővárosi Ítélőtábla 13. Gf. 40.338/2011/6.

Fővárosi Ítélőtábla 14. Cgtf. 44.222/2013/2.

Fővárosi Ítélőtábla 1. Pf. 21.049/2013/3. (FIT-H-PJ-2014-284.)

Fővárosi Ítélőtábla 1. Pf. 21.131/2014/4/II. (FIT-H-PJ-2015-442.)

Győri Îtélőtábla Pf. I. 20.068/2014/4. (GYIT-H-PJ-2014-99.)

ÍH 2004. 71.

ÍH 2004. 72.

ÍH 2004. 150.

ÍH 2005.31.

ÍH 2005. 32.

ÍH 2005. 125.

ÍH 2006. 82. 
ÍH 2006. 128.

ÍH 2006. 130.

ÍH 2007. 82.

ÍH 2009. 30.

ÍH 2009. 130.

ÍH 2010. 39.

ÍH 2011. 40.

ÍH 2011. 46.

ÍH 2011. 163.

ÍH 2013. 86.

ÍH 2014. 78.

ÍH 2014. 127.

ÍH 2014. 157.

ÍH 2015. 78.

ÍH 2015. 119.

ÍH 2015. 145.

ÍH 2015. 154.

ÍH 2015. 155.

ÍH 2016. 28.

ÍH 2016. 151.

ÍH 2017. 30.

KGD 1998. 106.

KGD 1998. 185.

KGD 2001. 2.

KGD 2003. 3.

Kúria Pfv. II. 20.045/2012/6. (K-H-PJ-2012-499.)

Kúria Gfv. VII. 30.186/2013/6. 
Kúria Kfv. I. 35.778/2014/5. (K-H-KJ-2015-787.)

Kúria Pfv. I. 21.069/2014/4. (K-H-PJ-2015-336.)

LB Cgf. VII. 32.752/1997/2.

LB Cgf. II. 30.159/2000.

LB Cgf. VII. 30.241/2001/2.

LB Cgf. II. 31.146/2002/2.

LB Gf. VII. 33.265/1999/5.

LB Gfv. II. 30.759/1999/8.

LB Gfv. 31.678/2002/2.

LB Pfv. II. 20.688/2008/4. (LB-H-PJ-2008-1658.)

PJD 2016. 5.

PJD 2016. 12.

Szegedi Ítélőtábla Pf. II. 20.039/2015/6. (SZIT-H-PJ-2015-41.)

4/2003. PJE határozat

1/2014. PJE határozat

PK 192. számú állásfoglalás

Európai bírósági döntések

C-513/03.

C-210/06.

C-256/06.

C-11/07.

C-25/10.

C-132/10.

C-31/11. 
1945 előtti bírói döntések

838. E. H. (Kuncz 1937a.)

B. T. 3493/1901. (Szende 48.)

B. T. 6122/1917. P. H. D. XII. 30. (Szende 53.)

B. T. 14.234/1933. (Kuncz 1937b. 399.)

C. 489/1883. (Szende 186.)

C. 4765/1883. (Jancsó 900.)

C. 1084/85. (Ü. L. 89. 12. sz.) (Szende 186.)

C. 1080/85. (J. 86. 118. 1.) (Nagy F. 340.)

C. 1442/1895. (Szende 28.)

C. 291/1900. (Szende 262.)

C. 1002/1900. (Szende 156.)

C. 1384/1903. (Szende 185.)

C. 81/1916. (Szende 156.)

C. 1004/1917. (Szende 193.)

C. 1413/1917. Hj. Dt. XI. 149. (Szende 186.)

C. 133/1918. (Szende 53.)

C. 1163/1919. (Szende 156.)

C. 4357/1920. Hj. Dt. XIV. 6. (Szende 186.)

C. 429/1922. (Szende 156.)

C. 3190/1922. Hj. Dt. XVI. 77. (Szende 185.)

C. 5291/1924. Hj. Dt. XIX. 11. (Szende 185-186.)

C. 3679/1927. Hj. Dt. XXI. 14. (Szende 186.)

C. P. IV. 9263/1927. (Kuncz 1937b. 177-178.)

C. P. IV. 3673/1929. (Kuncz 1937a.)

C. 2162/1934. (Kuncz 1937a. 67.)

C. P. IV. 2285/1934. (Kuncz 1937b. 177-178.) 
C. P. IV. 2423/1937. (t.t. 529-530.)

Pozsonyi T. 68/1900. (Szende 44.)

Külföldi jogszabályok

Aktiengesetz (Au.)

Allgemeines Bürgerliches Gesetzbuch (Au.)

Allgemeines Deutsches Handelsgesetzbuch (No.)

Bürgerliches Gesetzbuch (No.)

GmbH-Gesetz (Au.)

Partnership Act (1890) (Egyesült Királyság)

Spaltungsgesetz (Au.)

Todeserklärungsgesetz (Au.)

Umwandlungsgesetz (Au.)

Unternehmensgesetzbuch (Au.)

Verschollenheitsgesetz (No.)

Zivilgesetzbuch (Svájc) 